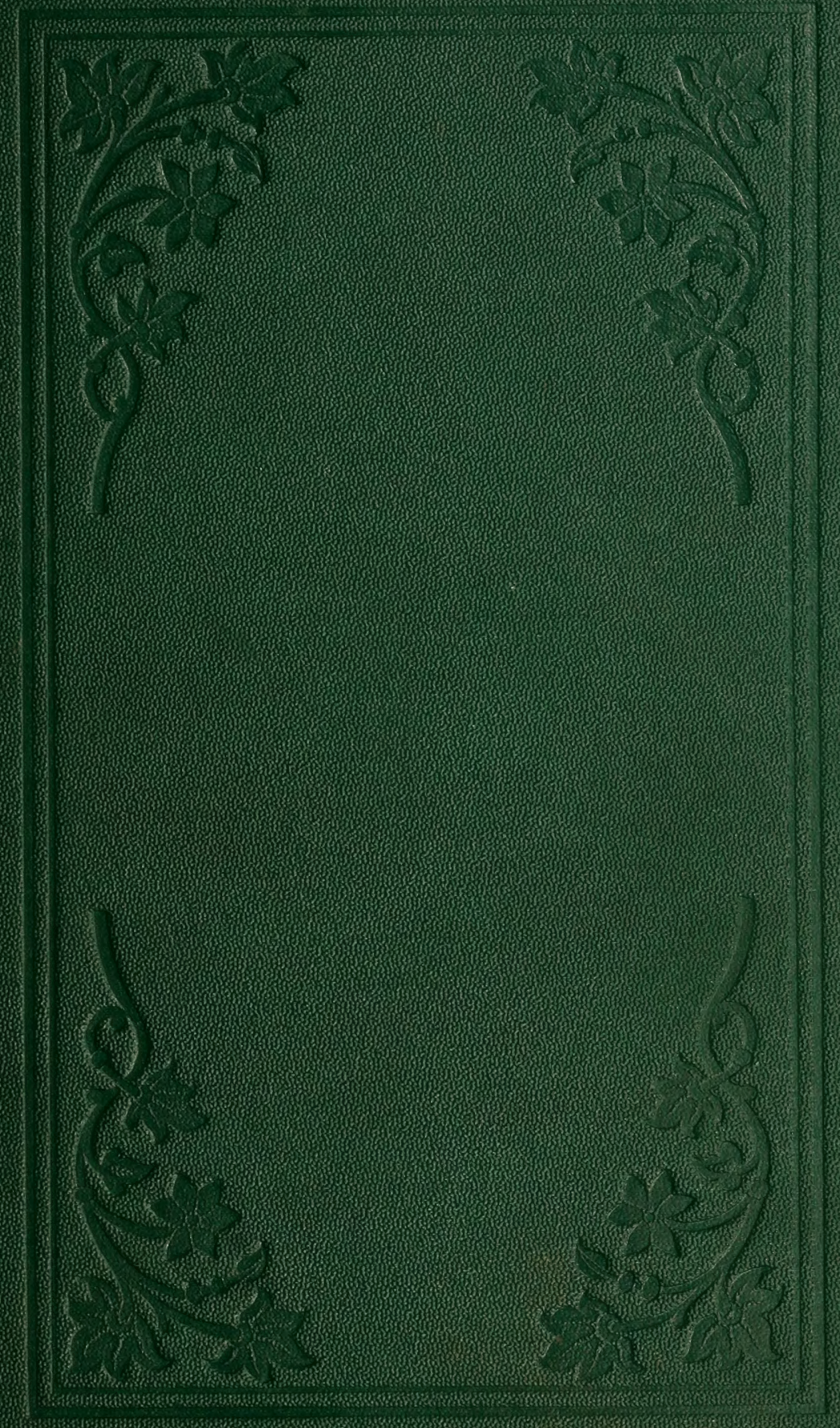







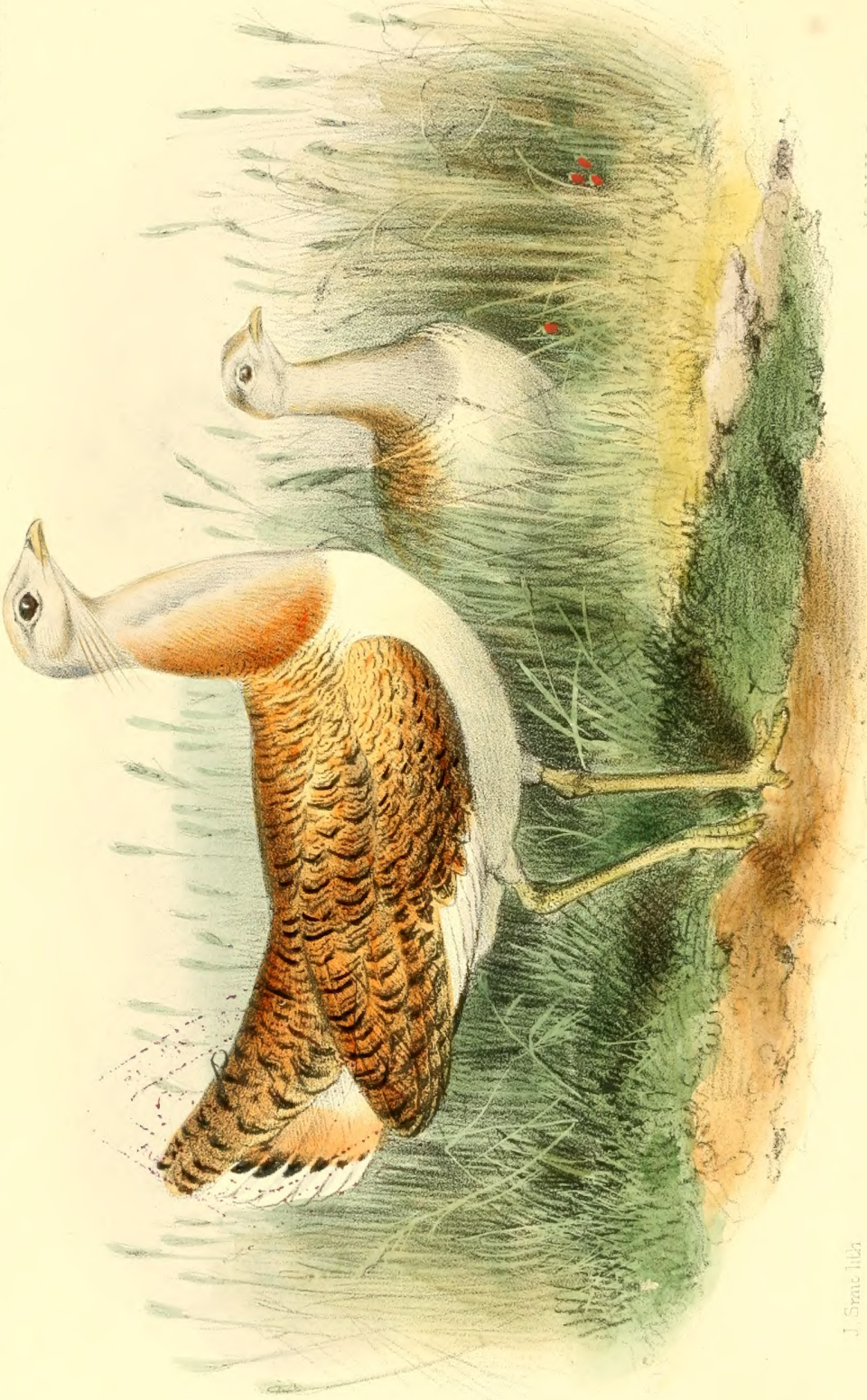




\section{BIRDS OF NORFOLK, \\ WITH}

REMARKS ON THEIR HABITS, MIGRATION,

AND LOCAL DISTRIBUTION:

BY

\section{HENRY STEVENSON, F.L.S.,}

MEMBER OF THE BRITISE ORNITHOLOGISTS' UNION.

IN THREE VOLUMES.

VOL. II.

"Cum medio celeres revolant ex æquore mergi, Clamoremque ferunt ad litora; cumque marinæ In sicco ludunt fulicæ; notasque paludes Deserit, atque altam supra volat ardea nubem."

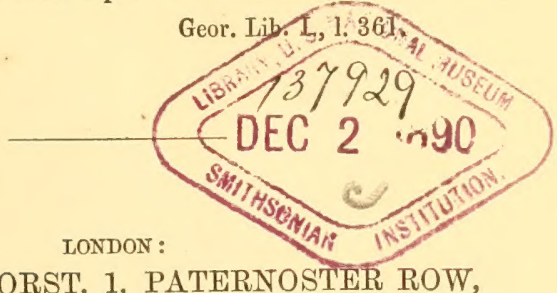

JOHN VAN VOORST, 1, PATERNOSTER ROW,

NORWICH :

STEVENSON AND CO..

1870. 



\section{ERRATA AND CORRIGENDA.}

Page. Line.

89 ... 10. For already read all ready.

124 ... 25. For 1825 read 1834.

144 ... Note. For above quoted read before quoted.

$148 \ldots 17$. Dele hyphen in down like.

172 ... 18. For Hickling read Sutton.

254 ... 19. For 1855 read 1853.

281 ... 4. For being read is.

291 ... Second note, $\uparrow$ for *

297 ... 4. Dele turned commas before borings.

327 ... 20. For has read have.

342 ... 5. For four of read four or.

400 ... 12. Dele nearly before all found.

418 ... 20. For W. Bligh read S. Bligh. 

Is completing a second though not final volume of the "Birds of Norfolk," I feel that some explanation is due not only as to the unavoidable delay in its publication but as to the motives which have induced me to extend the former plan of the work. I should state, then, that in the endeavour to render my account of the Great Bustard as complete as possible, with reference alike to its habits and habitat, when an indigenous species in Norfolls, and to the history of such specimens of either birds or eggrs as are still preserved in public and private collections, I was led into so considerable an amount of correspondence that this paper had been but recently completed, when read, in a condensed form, before Section D, of the British Association, at their meeting in Norwich, in 1868. This species, therefore, which, according to the classification I have adopted, properly commenced the present volume, may be said to have stopped the way for a considerable period, and has thus been the chief cause of a delay which I certainly have less reason to regret, since it has enabled me to put on record facts, retained only in the memory of our oldest inhabitants, and which a very few years hence would have been procurable only in a traditionary, and, therefore, far less reliable form.

There are but few individuals now living who remember the Great Bustard in Norfolk and Suffolk even in its latter days, and fewer still are the octogenarians who can recall the appearance of this noble species when still existing in "droves" in the Thetford or 
Swaffham tracts; and in expressing my warmest thanks to those who have so readily communicated all the information in their power on this most interesting subject, I hare to regret the loss-while the concluding portion of this volume has been passing through the press-of two valued contributors, the Rev. Henry Dugmore, of Beachamwell, and Mr. Anthony Hamond, of Westacre, whose reminiscences as sportsmen and naturalists have been of essential value to this work, and whose courtesy on all occasions in furthering its objects is held in very grateful remembrance.

Owing to more recent information respecting the late Rev. R. Hamond's Bustards, at Congham House, I have found it necessary to cancel my first description of them,* but the dates and particulars as now given are, I believe, fully reliable. I find, however, that I have by no means exhausted the list of Norfolk killed Bustards, as even within the last few months I have ascertained the existence of others, which will be described in an appendix to the third volume.

As regards the extension of the work, I may add that the favourable criticism that has, at all hands, been bestowed upon those biographical sketches, whereby in my first issue I sought to interest even non-ornithological readers in the life history of our "feathered favourites" left me no option but to describe, in like manner, the more familiar forms amongst our waders and wild fowl, and thus while my original notes have been entirely rewritten, the greatly increased amount of materials at my disposal has necessitated either an additional volume, or so considerable a curtailment of the remaining portions as would have destroyed entirely the uniformity of the

* A fer copies of the Bustard paper, in a pamphlet form, were printed for private circulation only. 
work. Under these circumstances, I determined to adopt the former alternative, and rather than divide so important and well defined a group as the Anatida, I have closed the present volume with the Grallo.

In treating of this large and most important group, so extensively represented, both in residents and migrants, within the bounds of this county, I have taken much pains to trace out the history of such species as have ceased altogether to breed in Norfolk; thus for all time to establish facts, which, years hence, under the altered condition of the soil, might be scarcely credited. But for the testimony of Sir Thomas Browne, modern ornithologists would never have supposed that the Spoonbill nested in Norfolk some two hundred years ago, and yet, with the exception of the Cormorant, no other indigenous species appears to have been lost to this county from the reign of Charles II. until the early part of the present century. Since that time, however, beside the Great Bustard, and from causes which I have elsewhere treated of, no less than three species, once abundant in our marshes and fens during the breeding season, have become altogether extinct-the Avocet, the Black Tem, and the Black-Tailed Godwit; while the Ruff and Reeve, represented only by a few pairs and in but one locality, must shortly be added to the list if the timely protection of the law be not invoked to prevent it. So strong is, I believe, the attachment of certain birds to the place of their birth, and so unerring the instinct which directs them, though absent in winter, to return year after year to the same spot, that, provided only a single pair survives to represent an indigenous race, the ancestral haunt will not be deserted; but if that last native pair be destroyed their place is rarely, * if ever, again filled, even though many

* As exceptions may be mentioned, the Hen Harrier and Montagu's Harrier, which still, occasionally, remain to nest in our 
representatives of the species on their migratory course may visit our shores in spring; for these, too, are seeking some far off thome, and the local race may thus pass away for ever.

Surely the success which has already attended the passing of the Sea-Bircls Preservation Bill, should encourage its promoters to seek an extension of its powers so as to secure a "close time" as well for all waders and wild fowl. Of the beneficial effects of such an Act there can be no question, judging only from my own experience during the last few years of the result of careful preservation, within a limited area, and yet nothing short of a legal penalty will deter a certain class of sportsmen (?) from shooting Snipe long after the pairing season has commenced, or even killing a Wild Duck from her nest if unfortunately met with at the same time. Remonstrance is in vain with such persons, who, accustomed year after year to perpetrate such enormities, are lost to all sense of shame. In fact, they can be classed only with those summer "excursionists" both in the North and South of England, whose holiday "sport" until very recently consisted in the wholesale slanghter of brooding Gulls and Guillemots; and if such birds, for their beauty, their cries of warning to the mariner, or simply on the ground of abolishing a cruel practice, are to receive protection during the breeding season, why not also our wader's and wildfowl, exquisite alike in form and action, and comprising many species that, in due season, rank amongst the greatest delicacies of the table, and which, in spite of the altered features of the country through drainage and cultivation* would still, under a protective system

marshes, and the Bittern, which, though extinct for some years prior to 1866, has since that time been both heard and seen at Hoveton during the summer months, and a nestling and eggs have been procured at Upton.

* In "Land and Water" for August 5th, 1870, are some extracts 
afford a fur greater amount of sport to the legitimate sportsman?

From the interest that attaches to those birds, which, though not directly included in the list of game, still form a highly attractive portion of the "bag" to most sportsmen, I lave dwelt somewhat in extenso on the local habits of the various Plorer, and Sandpipers that frequent our shores and mirshes, whilst for like reasons the Snipe and Woodcock have demanded even more space; and the facts which I have collected as to their local and general history will, I trust, be read with interest by those for whom they were more especially intended-the sporting naturalists. In the absence, also, at present, of any legal protection, I would here plead strongly on behalf of the Woodcock in spring, a bird which, though yearly evincing more and more disposition to nest in our woods and plantations, is too often driven away or destroyed by the relentless gumer. Only let country gentlemen, and game preservers generally, interest themselves in this matter,-for the remedy lies in their own hands, and by strictly prohibiting their lieepers and others from killing' Woodcocks later than the end of February, they will in all probability be re-paid by the interesting sight of a Woodcock sitting on her leafy nest in their own coverts. A sight, too, which, owing to the extreme tameness of the bird at such times, may be frequently and harmlessly indulged in.

In the selection of illustrations for this intermediate volume, the Great Bustard, as a now extinct species in

from a code of game laws in force in the state of New York, and thongh in a country whose waste lands as compared with cultivated are perhaps as ten to one, we find penalties attached to the killing or destroying of Wild Pigeons during the nesting season; WildDucks between the 1st of February and 15th of August; and Woodcocks between January 1st and July 4th. No wild birds nests to be robbed. No wild birds to be killed excepting in August, September, October, Norember, and December; exceptions in favour of naturalists and persons preserving fruit from depredation. 
Norfolk, naturally suggested itself as of chief interest, and I consider myself most fortumate in once more securing Mr. Wolf's services, whose original drawing for the present frontispiece was made from sketches of living specimens in the Regent's Park Zoological Gardens. The drawing on the stone and colour pattern were executed by Mr. J. Smit, and the plates have been coloured by hand by Mr. William Smith, with his usual care and skill.

The tinted lithographs by Messrs. Hanhart, of Breydon and Thetford warren are from sketches made on the spot by Mr. J. Reeve, of the Norwich Museum, and most accurately represent the main features of those highly interesting localities.

Breydon "muds," as here depicted at low water, have a world-wide celebrity, from the number of rare birds which have from time to time been killed thereon by the Yarmouth gunners; and the wild aspect of the Thetford warren scene, with the old warren lodge in the extreme distance, also faithfully represents the strangely undulating barren waste, which there forms a portion of the "breck" district. The two birds in the foreground to the left of the group of Lapwings, which have unfortunately lost much of their identity in being reduced on the stone, represent the Stone Curlew, the sole representative, now-a-days, in that bleak locality, of the Great Bustard.

H. S.

Norwich,

September, 1870. 


\title{
THE BIRDS OF NORFOLK.
}

\section{TIS TARDA, Linnæus.}

\author{
GREAT BUSTARD.
}

WrTn almost kindred feelings to those with which one contemplates, in the human race, the extinction of some great historic name, the naturalist, at least, regards the extermination amongst us of this noble indigenous species; and in either case we mark the same final cause-the failure of "heirs male." It is singular, however, considering the interest that appears to have attached, at all times, to so fine a bird, that our printed records of its ways and means should be, for the most part, so brief and unsatisfactory, and that the biography of the Great Bustard, like that of many other celebrities, should have remained to be written after it had ceased to exist, as a resident, on British soil. Of its general history pretty full particulars may be gleaned from the well-known worlis of Selby, Yarrell, Gould, and others; and to this, therefore, I need not refer; but I shall endearour to give as complete an accomt as possible of the Bustard in its special character of a Norfolk bird, and I have it fortunately in my power to make public a considerable amount of information hitherto mavailable. In particular I must mention that $\mathrm{M} r$. Alfred Newton (Professor of Zoology and Comparative Anatomy in the University of Cambridge), who has long been collecting materials for a complete monograph of this 
bird-a design he is still prosecuting-has, in the most friendly and liberal spirit, assisted me in many of the most important details, as will be evident to all who may peruse the present narrative. Mr. John Scales, formerly of Beachamwell, and $\mathrm{Mr}_{\mathrm{r}}$. Thomas Suuthwell, of Lyun, have also obligingly contributed much information relative to the bustard in the neighbourhood of Swaffham.

Besides the barren "brecks" of Norfulk and Suffolk, the great bustard, on good authority, appears in former times to have been extremely common on all the open parts of this island, which were suited to its habitsthe elevated moors of Haddingtonshire and Berwickshire, the desolate wolds of Yorkshire and Lincolnshire, Newmarket and Royston heaths on the borders of Cimbridgeshire, together with the downs of Berkshire, Wiltshire, Dorsetshire, Southampton, and Sussex, being all more or less frequented by it; but in every one of these localities it had ceased to exist before the last of the race of British bustards fell victims to the advancement of agricultural enterprise, in this and the adjoining county.

Of our local records the earliest in point of date* are contained in the published extracts from the Houselıold Books of the L'Estrange's, of Hunstinton, where, in the "Privy Purse Accounts," for the year 1527, we find the following entry:-

The xljst weke.

Wedynsday. Itm viij malards, a bustard, and $\mathrm{j}$ hernsewe kylled wt ye crosbowe.

* There is apparently but one earlier notice of the great bustard in Britain, viz., in the works of the celebrated Scotch historian, Hector Boethius, published in the year 1526, whose remarks on this species are referred to by Willoughby. The entries in the Northumberland Household Book, which commenced in 1512, and in which bustards are mentioned, are also nearly contemporary with the Hunstanton records. 
And, again, in the year 1530, amongst the list of gratuities-

Itm in reward the xxoth day of July to Baxter's svnt of Stannewgh [Stanhoe] for bryngyng of ij yong busterds, ijd.

Nearly a century and a half later, Sir Thomas

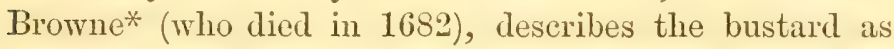

* The only other reference to this species to be found in the writings of this distinguished naturalist is contained in the following postcript to a letter written by Sir Thomas, in 1681, to his son Edward, as published in Wilkin's edition of his works (vol. i., p. 311) :- " Yesterday I had a cock bustard sent mee from beyond 'Thetford. I neuer did see such a vast thick neck: the crop was pulled out, butt as a turkey hath an odde large substance without, so had this within the inside of the slinne, and the strongest and largest neck bone of any bird in England. This I tell you, that if you meet with one you may further obscrue it." From this passage, it would seem that this wonderful observer of nature, as much in advance of his time in this, as in other scientific investigations, had arrived very nearly at the discovery of the "gular pouch" in this species (figured by Edwards, Bewick, and others), which has caused so much controversy amongst the most eminent ornithologists, and the existence of which, though now fully established, has been so often and so stoutly denicd. Space does not permit me to do much more than direct the attention of my readers to other works in which this interesting subject has been fully discussed. Suffice it, then, to say that the discovery made by Dr. James Douglas in the early part of the last century, of a large sac or pouch capable of much distention, and situated within the skin of the neck of the male bustard, but which the subsequent investigations of Professor Owen, Mr. Yarrell, Mr. Bartlett, Dr. Günther, and others failed to estal)lish, has been fully confirmed beyond the possibility of doubt, by Dr. W. H. Cullen, of Kustendjie, Bulgaria (see “Ibis," 1865, p. 143), from the examination of two fine adult males, killed in that country, both of which exhibited an opening under the tongue, leadiug directly into a pouch, which extended as far dowuwards as the furcular bone - "a separate and distiuct though delicate bladder, very much resembling in appearance the air bladder in fishes." One of these specimens now in the Museum of the Royal College B 2 
"not unfrequent in the champian and fieldy part of the county;" an expression which rather conveys the idea that they were not particularly numerous even at that period, and as, unfortumately, we possess no further notes of its existence in these parts for the next hundred years at least, we come at once to the commencement of the present century, when the gradual but inevitable extinction of the species forms the burthen of the story of each successive writer. "These noble birds," wrote Messrs. Sheppard and IVhitear, in 1825, "sstill continue to breed in the open parts of Norfolk and Suffolk, though they are become much scarcer than formerly. The places most frecquented by them are Westacre, in the former county, and Icklingham, in the latter. At both places they are carefully preserved by the proprietors. In the summer of 1819 , nineteen of them were observed together at Westacre." From that time, however, they appear to have gradually but surely decreased in both counties, it being a rare event to see

of Surgeons of London, was exhibited in 1865, by Mr. W. H. Flower, at a meeting of the Zoological Society. The second is in the University Museum at Cambridge. Dr. Cullen seems inclined to believe that this singular structure is a seasonal peculiarity in adult males only, and is by no means intended to contain water as formerly supposed, but is simply an air bag, connected, probably, with a strange sound emitted by the cock birds in the breeding season, but not heard at any other time. For a complete history to that date of the "gular pouch" controversy, see a paper by Mr. A. Newton in the "Ibis" for 1862 (vol. iv., p. 107). See also the "Proceedings of the Zoological Society" for 1865, p. 747, "Zoologist" for 1863 , p. 8556 ; and 1866, pp. 144 and 189; "Field," December 16th, 1865; and March 24th, 1866.

* Mr. Newton considers 1825 to be the date of the last Yorkshire nest, and 1826 of the last specimen; and it is probable that the race became extinct in Lincolnshire about the same time. Elsewhere in England it had been for some years exterminated, in Wiltshiro probably prior to 1820 . 
more than two or three in company, and in 1832, there is reason to believe that a nest found on the borders of Thetford warren was the last known in Suffolk, and a single bird observed liter in the summer of the sime year, on Iclingham heath, the sole survivor in that once noted locality. Mr. Newton thus refers to the appearance of this solitary bird-_"Mr. Thornhill, of Riddlesworth Hall, in July or August, 18:32, while walking one hot day across Icklingham heath, came upon a place where it was evident that some large bird had been rolling and dusting itself in the sand. On examination, he found close by a bustard's feather, and looking round him he perceived a hen bustard not many yards off, and this is the last well authenticated instance of the occurrence of this fine bird in Suffolk that I am aware of." The late Mr. J. D. Hoy, who, writing in November, 1832, recorded the occurrence of the last Suffolk nest in the "Magazine of Natural History" for 1833 (p. 150), also states that the old bird carried off her young in safety, and that a male bird and two females had been recently seen together on the same heath. Subsequently Mrr. Newton ascertained from the late Mr. J. D. Salmon (who, with Mr. Hoy, saw the young bird that was hatched from this nest when about half grown) that the nest was situated in a field of rye, into which the old and young retired when disturbed.

Norfolk now remained the last of our English counties to reckon the bustard amongst its resident species, nor was this privilege to be long enjoyed. In the spring of 1833, as recorded by Mr. Silmon ("Mag. Nat. Hist.," 1834, p. 458):-“Three females resorted to Great Nassingham Heath for incubation. Their eggrs consisted of two pairs and a single one. These were taken away under the impression that, as there was no male bird, they were good for nothing;" but this was possibly a mistaken impression, inismuch as in 
Spain,* where they still abound, the cock birds in Andalucia are known to part company from the hens in the month of May, and, leaving the latter on the uplands, betake themselves to the marshes. Still, however, to quote once more from $\mathrm{Mr}$. Newton's notes, a small flock of hen bustards, including the parents of the egrgs mentioned, continued to occupy the country around Swaffham for some years longer, but there is no reeord of any cock bird having been observed-it is, therefore, a sad reflection when we think that had a male bird been procured from the continent, and liberated in that district, the great bustard might still have been an indigenous bird in this country. Be this as it may-the hen birds are asserted to have dropped egres at random, continually, as the season came round, without taking: the trouble to form their usual slight nests-and this continued until the year 1838. In the month of February of that year, a female bustard was brought to the Cambridge market, where it was bought by $\mathbf{M r}$. Smith, the butler of Pembroke Hall, for Mr. William Borrer, of Cowfold, in Sussex, then an undergraduate of Peterhouse, in whose possession it still remains;

* Lord Lilford, who has had recent opportunities of observing these birds in Spain and has very kindly favoured me with several notes respecting them, states that "I'hey are extremely common in all the central and southern parts of that country suited to their habits, particularly in the immense plains of Estremadura, the valley of the Guadalquivir, about Seville, the arid, treeless, plains of La Mancha and old Castile. The main body arrive in the country early in March, and about the middle of April pair. My own impression is they are not strictly polygamous, though instances thereof often happen. The greater number leave Spain about October, though a good many always remain in Andalucia during the winter. I have seen upwards of a hundred together near Seville, in April; and I believe in the autumn, after harvest, they collect in immense numbers in the grass marshes below that town." 
and that gentleman having taken the trouble of tracing its history, ascertained that this specimen was killed at Dersinglam, near Castle Rising, in Norfolk, on the 28th of the preceding January.* Later in the same year (1838), another specimen, also a female, was killed at Lexham, near Swaffham, $\uparrow$ and sent to Mr. Knight, of Norwich, to be preserved for the late Mr. F. W. Keppel. This bird was found on dissection to contain an egg nearly ready for exclusion, and when examined, in the flesh, by Mr. J. H. Gurney and others, had the down under the breast feathers suffused with a most delicate rose coloured tint, which, according to Yarrell, was also observed in the Dersingham bird, and, if looked for, will probably be found in all specimens. It may even still be open to doubt whether this was really the last killed in England deserving the name of a British bustard, since in Mr. Dowell's MS. notes I find the following brief but important entry :-_ A great bustard was killed by $\mathrm{Mr}$. Woods, of Morston, about 1837, and was sent to Lord Charles Townshend." On further enquiry, that gentleman's son, Mr. W. G. Woods writes, under date of March 20th, 1865 :- “' The great bustard I took to Lord C. Townshend, about twenty-four years since; it was a female, but whether young or old I don't know. I never heard of its being seen there before. It was lilled in autumn." Mr. Dowell, who, I believe, made the entry in his note book from a verbal statenent

* Mr. Joseph Clarke, of Saffron Walden, also confirms this account in a recent letter, and adds that having heard of this specimen, he at once proceeded to Cambridge with the hope of securing it for the Saffron Walden Museum, but Mr. Borrer had already purchased it.

† This is the same bird recorded in the "Annals of Natural History" for 1838 (vol. i., p. 334); and again in 1839, in vol. iii. of the same journal, p. 141. 
of Mr. Woods, gives the date of this female* as "about 1837 ;" Mr. W. G. Woorls, however, considers that it was "about twenty-four years since," that is to say, from the date of his letter to me in 1865, which would make it some three years later than, instead of one year prior to the Lexham bird. That the former supposition is by no means impossible is further shown by a record in Mr. Lubbock's "Fauna" (published in 1845), in which that gentleman says "one bustard three years back was observed in the parish of Brilgham, near Harling," a statement which Mr. Newton, after much enquiry of people in that neighbourhood, is rather inclined to credit, and adds, "whatever it was, though shot at by a gentleman, the late Mr. George Montgomerie (then living in the adjoining parish of Garboldisham), it was not obtained, and hence the uncertainty that exists. I have met with several rumours, each apparently with an independent origin, of a bustard having been seen in Norfolk about that time (1842), so that I camnot but think there is some truth at the bottom of them."

Such, then, in brief, is the history of the gradual and final extinction of this noble species in the Eastern Comnties. In order, however, better to comprehend the causes which led to so unfortunate a result, I have thought it desirable to collect from every available source the scattered records existing of its habits, numbers, and local distribution. Yet, besides such notes as have appeared from time to time in natural history publications, there remained to be gathered from the evidence of shepherds, warreners, gamekeepers, labourers, and others, still living in localities where these birds had so

* I have been unable, after many enquiries, to ascertain whether this hird was cooked and eaten at the time, or preserred as a stufled specimen. 
recently existed, much valuable information ; and to this end, commencing in the year 1851, Mr. Alfred Newton and his brother Mr. Edward Newton, then residing at Elveden, deroted a considerable amount of time and labour, more especially in the neighbourhood of Thetford, on the borders of Norfolk and Suffolk. Of this "hearsay" evidence, I consider myself most fortunate in being enabled to give a summary, since, having been carefully written down at the time, after conversations held with many of the oldest men, and those most conversant with the now exterminated birds, on the Elveden and ardjoining estates, it contains many interesting facts, which in a few years might have been lost altogether, or, at best, would have survived only in the vague and unsatisfactory form of local traditions.

During the last hundred years the story of the bustard in Norfolk and the adjoining parts of Suffolkfor it would be inexpedient here to be restricted by merely civil limits-seems to be this. The open country round Swaffhain, and that near Thetford, formed each the head-quarters of a "drove," for so an assemblage of these birds was locally called. The Swaffham tract, a long narrow range, chiefly lying in the "breck" district, bounded on the east by the enclosed part of the county, and on the west by the fens, extended probably from Heacham in the north to Cranwich in the sontl, if indeed it did not reach by way of Mundford and Weeting across the borders of the county to the Wangford and Lakenheath uplands, which are strictly part of the Thetford or Stow tract, to be presently considered*. In this

* It is possible, also, that the two tracts were more conterminous than the evidence at hand shows, and that there was communication in a more direct line by way of Ickborough, Tofts, and Croston, between the two "droves." It seems to have been a belief, that when the cock birds failed in the Swaffham tract, the hens 
Swaffham tract the drove formerly consisted of, at least, twenty-seven birds, as the Rev. Henry Dugmore, of Beachamwell, informs me that he perfectly remembers (although he camnot recall the exact date*) riding on one occasion, at Westacre, in company with the late Rev. Robert Hamond, and, when walking their horses across the open country, the whole drove of twenty-seven bustards flew by them within fifty or sixty yards. Mr. Scales, also, in the same locality once saw twenty-three together; and Mr. Hamond, of High House, Westacre, can recollect this drove as numbering twenty-two birds. There can be little doubt, therefore, if earlier information were available, it would be found that in strength this drove was by no means inferior to that which at the same time frequented the other tract. Again, from twentythree or twenty-two, this drove subsequently decreased to seventeen or sixteen, then to eleven, at which number $\mathrm{Mr}$. Hamond remembers it long stood, and finally dwindled to five and two; all accounts agreeing in this, that the last remaining birds were hens only. The cause of this diminution has already been briefly stated in the "Introduction" to this work (vol. I., pp. li., lii.) It may be, however, convenient to repeat here more fully that the hen bustard nearly always laid her eggs in the winter-sown corn, which in former days was, almost without exception, rye-sown broadcast after the old fashion. As the mode of tillage improved, wheat

there were visited by birds of the opposite sex from the other locality; but this is not very likely to have been the case, as it is pretty nearly certain that at the time when the presence of the cocks in the Swaffham tract was most desirable there were none left in the neighbourhood of 'Thetford.

* Mr. Gould, in his "Birds of Great Britain," records this same incident, quoting from a letter addressed to the Rev. John Fountaine by Mr. Henry Dugmore, and though the date is not given, it is said to have been "as far back as 1820 ." 
was gradually substituted for rye, and, at the price that grain fetched in those days, the desire of not using more seed than was absolutely necessary brought about the invention of the drill, by means of which corn, thus sown, was capable of being kept free from weeds with much greater facility. First, parties of children were sent into the fields to perform this operation, and then speedier, if not more thorough, execution was obtained by the use of the horse-hoe. Thus, every nest made by a bustard in a wheat-field was sure to be discovered-perhaps in time to avert instantaneous destruction from the horses' feet or the hoe-blades-perhaps, and this probably much the most often, only when the eggs had been driven over and smashed, and their contents were pouring out on the ground. But even in the first case, instantaneous destruction being avoided, the eggs were generally taken up by the driver of the hoe (in defiance of the Act of 25th Henry VIII., which, though often enforced when smaller and less valuable species were concerned, seems in the case of the bustard to have been regarded as a dead letter), and carried by him to his master or mistress. If they were not chilled by the time they reached the farm-house they were probably put under a sitting hen-for all persons seemed to imagine, till they tried, that the rearing of young bustards was as easy as the rearing of young turkeys. If, however, there was no hope of success in this direction, they appear often to have been preserved as natural curiosities, to lie, with grotesquely shaped flints and petrified Echini (the "fairies" loaves" of the district) on the parlour mantel-piece or book-shelf till they met with the usual fate of such fragile articles, though some four or five specimens are known to have escaped all such risks, and are actually still in existence. But in either of these cases the result was the same. No young birds grew up to fill the gaps made in the ranks of the old ones according to the c 2 
common course of nature, to say nothing of those caused by occasional violent deaths: for, althongh Mr. Hamond (following the example of his father before him) and most of his neighbours allowed no molestation of the bustards on their estates, yet there is little doubt that every now and then one fell to the gun, or was caught in the gin of a depredator, while the smaller proprietors were by no meins actuated by any feelings for the perpetuation of the stock, and a few of the larger ones occasionally wished to supply themselves or their friends with specimens for their collections or even for edible purposes.* Not a thought of the extermination of the species seems to have passed through their minds. Either they were entirely indifferent about the matter, or else they believed that since, as long as they could remember, there had always been bustards on their brecks, therefore bustards there would always be. Several of the specimens thus obtained still exist in various collections, and an enumeration of them with all the particular's of their history, now to be obtained, will

* The late Mr. Birkbeck informed Mr. J.H. Gurney that he remembered on one occasion a West Norfolk friend sending a young bustard to his father as a present for the table, showing that they were occasionally so used in West Norfolk, as late as the end of the last or beginning of the present century. The late Col. Hamilton, also, in his "Reminiscences of a Sportsman" (vol. i., p. 178), gives an account of a bustard, which he had been invited to dine off some fifty years ago by the late Mr. Hyde, of Lexham Hall. It had been shot, it appears, by a teuant of Mr. Hyde's, who, when riding up a lane with his gun and a terrier dog, saw a large bird fly across about twenty yards before him. He shot at and winged it, but, on recovering itself, the bird ran so fast that but for his terrier which seized and held it till he came up, it must have escaped. "It proved," says the colonel, "an excellent bird, and the breast was of two colours, brown and white." Mr. Newcome says that when Mr. Colquhoun lived at Wretham, it was reported that there was generally a bustard or two hanging up in the larder. 
conclude this notice. It is to be remarked that cock birds are said to have been comparatively scarce in this drore, three being the most that are spoken to by any eyewitness, and, as has just been staterl, when the nunlyers of the drove were much riminished, cochs were entirely wanting. These olserrations lmobably refer to the old cocks, which so greatly surpass the hens in size, for it must be remembered that, as is known through foreign observers, the male bustard is sereral years in attaining its full growth, and until then it cannot be readily distinguished from the female at a distance.*

Whether the bustard was (and, in countries such as Spain and Central Germany where it still exists, is) polygamous must be regarded as an open question. The eridence of Norfolk and Suffolk observers certainly tends to the belief that it was so; but, on the other hand, the late Professor Naumann, who was a most acute ornithologist, and had abundant opportumities for investigating the economy of this species in Saxony, denies (Tögrel Deutschl, rii., 11). 35-41) that such mas the case, except to a rery limited extent, which exactly agrees with Lord Lilford's opinion, as previously giren (note, p. 6). So also the evidence is somewhat defective as to whether the bustard was resident or migratory. According to Mr. Scales, and a more competent authority there can scarcely be, the cocks annually disappeared at the latter end of spring and beginning of summer. What became of them it is not easy to conjecture, but it seems certain that towards the breeding season they ceased to live in company with the hens, and were, therefore, at any rate, partial migrants. The hen birds

* A young male of foreign origin, kept in confinement by Lord Lilford, did not acquire its beard until the beginning of April in its second jear. 
seem also, but this is not so certain, in East Anglia to have absented themselves from the time when the harrest was gathered in till the beginning of the new year. Indeed, the existing evidence of the appearance of bustards from the middle of September to Christmas is very scanty, and this is the more remarkable because this period of the year, forming a great part of the shooting season, is just when one would have expected more to have been observed than perhaps at any other time.* Early in January these birds showed themselves, and remained in droves, generally frequenting the turnipfields, where they fed largely on turnip-tops, and till the winter-corn was sufficiently grown to afford them shelter, they were seen commonly enough. When the corn, the rye especially, was coming into ear, the hen birds retired into it to form their nests-shallow holes scraped in the ground with a slight bedding of dry grass. Here they laid their two eggs-perhaps, indeed, three occasionally, but testimony as to the third is not altogether conclusiveand endeavoured for some months to avoid observation. When the corn was cut, they gathered again into droves for about a month or six weeks, after which time they

* The late Mr. [Henry] Elwes, as recorded, by Yarrell, "shot a hen bustard to a pointer in a turnip-field, at Congham, in the autumn of 1831." There is also a story of Colonel Wildman, of Newstead Abbey, Nottinghamshire, having killed a bustard in Norfolk during the shooting season, but date and other particulars are wanting. At Elveden, between the th and 18th of Sept., 1813, the late Sir Alexander Grant shot at a young bustard, which was caught in a rabbit-trap a few days after (the 27th.) The bird shot by Mr. Wood, as previously mentioned, was killed in autumn. The L'Estrange Household Book, already quoted, mentions one brought to Hunstanton in the forty-first week, which, counting (after the old style) from 1st of Mitrch, would be that beginning December 6th. These are all the occurrences bearing upon this point, and thus there is positively no precise information respecting the appearance of a bustard during the months of October and November. 
once more disappeared, and were not seen again until the frosts and snows of January brought them into the turnip-fields, and displayed them prominently to the observation of the shepherds and other field labourers. Mr. L. Sooby, formerly a tenant of Mr. Hamond's at Gayton, is inclined to connect their appearance on a particular part of his land with the prevalence of a rather common weed, the "Owl's crown" (Filago germanica, L.), which he said they used to eat;* but this evidence rests entirely on that gentleman's authority, as does also a statement that in the summer the evening was the time when they usually came forth to feecl. In addition to this, he speaks very positively as to the fuct that in the last days of the species the surviring hens used to scrape many more nest-holes in the ground than there were birds to occupy them, and on all sides it would appear that, if at that time a cock bird could have been procured from any other country and liberated in this locality, the species would have been preserved at least for a few years longer.

The precise time at which the extinction of the Norfolk bustard took place, like that of the extinction of many other species, is not, perhaps, now to be determined with accuracy. The year 1838 is the last when examples are known with certainty to have been lilled;

* The food of this species in a wild state, as in confinement, appears to be somewhat varied, as Naumann specifies many different kinds of plants and other green food, together with beetles, mole-crickets, and grasshoppers. Selby states that, bevides its usual diet of grain, seeds, and green corn with turnip-tops in winter, "it also eats worms, and has been known to devour mice and young birds, which are swallowed whole;" and a still earlier authority, Willughby, writes, "It feeds on corn, seeds of herbs, colewort, dandelion leaves, \&c. In the stomach of one dissected, we found a great quantity of hemlock seed, with three or four grains of barley, and that in harrest time." 
but several persons believe, and with some show of reason, that a bird, or even two birds, lingered on in this tract till 1843 or even 1845. This last date, however, is the very latest that can be assigned, and the probability, from the evidence available, is in favour of the extermination having been thoroughly effected seven years earlier-namely, in 1838.

Though it is desirable to mark, as has been done, the former existence of two distinct droves of bustards, it must not be inferred that the birds belonging to the one just spoken of in the country round Swaffham, and included entirely in Norfolk, did not occasionally commingle, by the route already indicated, with the other drove haunting the tract nearer Thetford, and stretching from Brettenham and Snarehill, in Norfolk, across the county border to Barnham, North Stow, Icklingham, and much further into Suffolk, till with perhaps a slight interval it joined the tract around Newmarket, celebrated by Ray as a locality for this species, while westward it was only bounded by the fens, and at Lakenheath became almost conterminous with the southern limits of the Swaffham tract. There is an additional reason, also, for considering this tract separately from that first spoken of. It seems probable that the causes which effected the extinction of the bustard there had but little to do with it here. Owing to the comparatively poor soil the staple crop of grain in this locality has only very recently been changed from rye to wheat, if, indeed, the change is now entirely consummated. Another cause must, therefore, be sought, and this appears to have mainly been the planting of long belts of trees with the object (as briefly stated in the "Introduction") of sheltering the arable land from the violence of the wind, the ill effects of which in blowing the light sand, here chiefly composing the surface soil, is one of the most serious obstacles with which the 
agriculturist has to contend.* The continuous drifting forward of innumerable sharp angular particles, consisting almost entirely of comminuted flint, so chafes the tender cuticle of young corn or turnips, that an exposed breck after a few hours' gale, looks as if it had been subjected to a blast of air at an excessire temperature, and in a day or two the regetation withers away to the destruction of the farmers' hopes. When this has happened remedy he has none, he can look alone to prevention. Accordingly, under the fostering care of the landlords, numerous plantations have, within the last fifty or sixty years, sprung up throughout the whole of this tract, not only entirely changing its aspect but rendering it entirely unsuitable to the wary habits of the bustard, which soon learned to become jealous as any strategist of what might afford an enemy harbour. Prior to the practice of planting becoming general, the bustard was probably as numerous here as any where in England. $\dagger$ Icklingham heath has been for many years

* My limited space enables me only to quote the title of an interesting paper on this subject in the "Philosophical Transactions," to which I would here draw the attention of my readers, being an account of a very remarkable disaster, originating on Lakenheath warren, apparently about the end of the sirteenth or beginning of the serenteenth century, and devastating the land for a distance of five miles till stopped by the river at Downham :"A curious and exact relation of a Sand-floud, which hath lately orerwhelmed a great tract of land in the county of Suffolk; together with an account of the check in part given to it; communicated in an obliging letter to the publisher, by that worthy gentleman Thomas Wright, Esq., living upon the place, and a sufferer by that deluge."-Phil. Trans., 1668, vol. iii., pp. 722-725.

+ It is of this particular locality that Yarrell writes ("Brit. Bds.," 3rd ed.), "My worthy friend, the late Mr. Frederick J. Nash, of Bishop Stortford, several times told me, that when he was a joung man, and then taking the field as a sportsman, he once saw nine flights of bustards in one day, not far from Thetford, in Norfolk. Some 
celebrated as a habitat for it. George Edwards, in his "Natural History," says that the subject of his plate of this bird, which bears date 1746 , "was presented to me fresh and in fine order by Mr. Daniel Gwilt, of Milkstreet, London, my much esteemed friend and relation ;" and the Rev. Robert Gwilt, the present representative of that family, long seated at Icklingham, has lately been good enough to furnish the information that Edwards's original drawing from a bird killed at that place is now in his possession. Yet it would seem that Icklingham was not the chief place of resort for bustards in that tract, since the testimony of all the oldest men of the neighbourhood, now or lately surviving, points to North Stow heath as the stronghold-though, in truth, the difference is but slight, for this last is in an adjoining parish. But no doubt the birds shifted their ground from place to place within the tract according to the supply of food. Tradition gives forty to thirty as the strength of the drove in the last century, and it does not appear to have much, if at all, diminished at the beginning of the present, for that estimate is confirmed by several of the eye-witnesses examined, one of whom peeping over a warren bank, at Elveden, as near as he could recollect about the year 1812, and just after harvest, saw quite close to him a drove which might have consisted of forty birds, "large and small," which sat there preening their feathers. The evidence of another man, who, as a boy, was about that time or a little earlier, shepherd's page at Barnham, where he caught a young bird alive, tends also to show that from

of these birds were probably seen more than once, but at that time, the beginning of the present century, the country between Thetford and Brandon, and from thence southward to Mildenhall, was considered the head-quarters of the great bustard in the counties of Norfolk and Suffolk." 
forty to thirty were usually seen together there in winter.* About this period, however, commenced the practice mentioned of planting trees, and the effect of this agricultural improvement soon became manifest. Indeed the year 1812 may, perhaps, be looked upon as the bustard's "grand climacteric"-the turning point of its existence in this locality. None of the witnesses to a later period can speak roundly of such numbers as forty or thirty being seen; the largest droves spoken to henceforward consisted of twenty-four, and even this may have been as early as the year just mentioned. The late Mr. Newton, of Elveden, with his brother-inlaw Mr. Waddington, of Cavenham, and another gentleman, were riding across Icklingham heath when, at the end of a plantation, they came suddenly on two dozen bustards, which at once took wing and dispersed in all directions. After this time no one speaks of seeing more than eighteen, and as the experience of the different persons questioned draws nearer to the present day, fifteen or fourteen, nine, seven, six, five, three, and two are successively the numbers specified by the various eye-witnesses. Here, too, as in the Swaffham tract, the last survivors are reported to have been hens only.

Though a considerable amount of protection was accorded to this bird by some of the largest proprietors, the Duke of Grafton, at Euston, $\dagger$ Mr. Newton, at

* It is of course, in most cases, very difficult to get at the date of any of these occurrences, but in this case it may be approximately reached. The young bustard this man caught was ultimately purchased, he said, by "Lord Paget," who then lived at Wretham. Now this Lord Paget (subsequently the celebrated Marquis of Anglesey) in March, 1812, became Earl of Uxbridge. It is, therefore, pretty evident from the name applied to him by the witness, that the fact mentioned must have taken place before the higher title was assumed.

+ Mr. Lubbock states, in 1845, on the authority of a veteran sportsman, Sir John Shelley, "that forty years ago parties used to D 2 
Elveden, and the Messrs. Gwilt, at Icklingham, others permitted their persecution. George Turner, formerly a gamekeeper at Wretham, and subsequently living at Thetford, was suffered by the late Sir Robert Buxton, Lord Cornwallis (the latter owning the Culford estate, in which was included North Stow heath, already spoken of as the "head place" for these birds) and others, not only to go in quest of them with a swivel gun, mounted on a wheelbarrow screened with boughs, a parchment stalking horse, and similar devices, ${ }^{*}$ but even to construct masked batteries of large duck-guns, placed so as to concentrate their fire upon a spot strewed with turnips, and there is no question that first and last he was the means of lilling a very considerable number. The guns forming his batteries had their triggers attached to a cord perhaps half a mile long, and the shepherds and other farm-labourers on the ground were instructed by him to pull this cord whenever they saw the bustards within range. A shepherd on the Place Farm, at Thetford, of which Sir Robert Buxton was landlord, has stated that on one occasion, about the year 1820 , he saw five or six bustards on the fatal spot, whereupon

be made to go and look at the bustards, by those who visited at the Duke of Grafton's, and other great houses in the neighbourhood of Thetford, and that a distant view of some of these birds could always be obtained."

* "There is an old blacksmith," writes Lord Lilford, "at Shrewton, about half-way between Salisbury and Devizes, who well remembers people coming from London to shoot bustards. They used to drive round them in a cart gradually diminishing the circle, and a good many were killed in that manner. The same method is adopted in Spain and in the Danubian Principalities. I do not think the bird was ever so abundant on Salisbury Plain as in Norfolk, the largest number I could hear of, together, in the former district was fourteen." The stalking-horse is mentioned by the German ornithologists as a common means of getting within shot of bustards. 
he pulled the string as he had been told to do, and shot two cock birds, weighing twenty-four or twenty-five pounds each. There is evidence, also, of hen bustards having been captured on their nests. Already before 1811, Coulson, keeper to Lord Albemarle, had tried ineffectually to throw a casting-net over an old bird at Elveden, as she was sitting, but he was obliged to content himself with taking her eggs and putting them under a hen, when in due time they were hatched, and and the young, being successfully reared, lived in a garden for some time till killed by dogs, which accidentally obtained an entrance. But more than ten years later, Mr. Booty, a farmer, at Barnham, performer the feat with greater dexterity at Stow, and carried off the old bustard which he kept in the cheese-room of his farm house. Besides this a gunsmith, at Bury St. Edmund's, is said to have encouraged the destruction of these birds, buying them when brought to him without being particular as to whether they were obtained with the leave of the proprietors or without it, and thus altogether it would seem as if the bustards in this tract of country were more molested than those around Swaffham. To this cause may, perhaps, be attributed their earlier extinction, for while the latter certainly lingered till 1838, there is no trustworthy evidence whatever for believing that the former existed later than 1832, in the autumn of which year Mr. Thornhill, of Riddlesworth, as has been mentioned, had a very good view of one on Icklingham heath, and it may be pretty confidently stated that this was the last time a bustard was observed in that locality.

As may have been expected, there seems to have been little or no difference in the general habits or mode of nidification of the bustards in these two tracts. They appeared and disappeared at the same periods of the year, and frequented localities as nearly as possible 
identical in character. One peculiarity in their habits, which does not seem to have attracted much notice before, should here be mentioned. This was the pugnacity of the cocks in the spring. At Elveden a shepherd (at least before the year 1820) on one occasion saw two cock birds fighting, and so intent on the combat were they that he ran up and killed one with his staff. This bird was sent to London to the late Mr. Newton and eaten. Of between fifteen and twenty nests, the situations of which have been more or less precisely pointed out or described by eye-witnesses in the Stow tract, only two were not in rye; ${ }^{*}$ of these two, one was said to have been on the short rabbit-cropped ling of a warren, and the other in a young plantation of about two years' growth; but, as it was often customary to grow rye between the rows of trees, before they had attained any height, it seems quite possible this had been done here, and in that case the occurrence would not be so very exceptional. It has been so constantly asserted by various authors that bustards were commonly taken by greyhounds, that the statement has become an article of faith among many persons. Whatever the practice may have been in other parts of England, there is certainly no evidence that it was pursued in Norfolk or Suffolk. The Swaffham Coursing Meeting was one of the most celebrated in the whole country, and in the open districts of both counties the sport of coursing was formerly most extensively followed, greyhounds being very generally kept, yet none of the older inhabitants have ever heard, except from

* Mr. Lubbock ("Fauna of Norfolk," p. 41), speaking of Coulson's attempted feat, says the nest was "in a pea-field" ; but the statement is otherwise uncorroborated, and Lord Albemarle, who was the author's informant, does not seem to have been himself an eye-witness, and may have been misinformed. 
books, that bustards were taken by dogs. One eyewitness, in Suffolk, speaks to a bird having run for about twenty yards (a very short distance for a course), pursued by a greyhound, which nearly succeeded in eatching it, but this, he stated, was an accidental circumstance, and all other testimony is to the fact that a bustard could rise "as light as a lark."* The capture recorded by Mr. Lubbock ("Fauna of Norfolk," p. 41) of a bird at Sprowston, to be hereafter mentioned, is clearly not to the point, since "the greyhounds came suddenly through a gate close to it, and seized it before able to take wing," so that there was probably no course at all. If ever the coursing of bustards by greyhounds was practiced in any part of England, it could only have been when the birds were very young, or, being old, had moulted out their quill feathers. $\dagger$ I may here add, how-

* A male bird observed on two occasions by Messrs. Sheppard and Whitear, "suffered itself to be approached to about the distance of a hundred yards, then walked deliberately a few paces and tool: wing, without the least difficulty." The often quoted lines, also, from the "Polyolbion" -

"The big-boan'd bustard then, whose body beares that size,

That he against the wind must runne, ere he can rise."

only show that Drayton was not so good an observer of nature as he was poet, for the habit mentioned is common to a very large number of birds, as every snipe-shooter knows. In the "Illustrated London News," No. 733, for December 8th, 1855, a contributor spoke of the days when English coursers

"Gaily slipped their greyhounds at the bustards in the fens."

But the editor of that newspaper preserved a very discreet silence when requested to supply the authority whence the "quotation" was made.

+ Naumann ( $\nabla$ ög. Deuischl., vii., pp. 45, 46) suggests a probable origin for the story, which he calls "absurd," in the fact that bustards are occasionally incapacitated for flight by haring their wing coverts frozen, to which several authorities bear witness; but such an event must be rare in any country, and 
ever, that my friend, Mr. W. H. Roberts, who practised for many years as a surgeon at Feltwell, where he first took up his residence in 1811, informs me that he used frequently to see bustards on the large open fields about Cranwich, though never more than two or three together; and on riding after them on horseback, they would run a considerable distance before taking wing.

Mr. Lubbock, referring to the wholesale slaughter committed by that notorious otidicide George Turner, of Wretham, states that on one occasion having placed lis big duck-guns so as to command the spot where he had laid food for the bustards, he succeeded in killing seven at one discharge. I have ascertained, however, that this feat, although Turner "tulit honores," was, after all, not performed by him, but by another person. Mr. E. Abbott, of Parndon, Essex, and formerly of Wretham, thus describes the occurrence in a letter recently received from him, adding at the same time several additional particulars:- "I think it was early in the spring of 1812, as far as I can recollect. The guns, four very large ones, had been fixed many days by Turner (the then head keeper at Wretham, where my father was steward and manager), before anything like an opportunity offered of killing more than three or four. When one wild day, returning from Thetford, where I had been sent by my father, I saw with a pocket telescope, which I generally carried, that no less than ten birds were all directly before the guns, and on the very spot where Turner had constantly been wishing to see

especially so in England. In an interesting paper on this bird by the Rev. A. C. Smith, the author inclines to the belief that the "sport" of coursing bustards was followed "in drizzling wet weather" when "the birds' feathers were soaked in rain" (Wiltshire Magazine, vol. iii., pp. 141-144). A singularly unsportsmanlike practice it would seem! 
them. I pulled the cord attached to the guns from the place of ambush, and thus shot seven at one discharge. Six were killed outright, and one fine old fellow had his wing broken, and was, of course, soon despatched with a stick I had. I remember the birds were presented by Turner to the then Prince of Wales (George IV.), the Duke of York, and others, * and I believe had the effect, in some degree, of procuring the berth of head-gamekeeper at Windsor for Turner's son, where he lived till his death."

Mr. Thomas Brightwell, of Norwich, lately informed me that on one occasion, when Mr. Barker lived at Anmer, he and his son saw a bustard as they were walking over the open "brecks" between Anmer and Houghton; and in the same locality, according to a communication received through the late Lady Middleton, a bustard was found and fired at by Lord Henry Cholmondeley when quite a young man.

In the "Catalogue of Norfolk and Suffolk Birds," by Messrs. Sheppard and Whitear, those gentlemen state that "Mr. Hardy, of Norwich, has more than once succeeded in domesticating this species," and through

* In Ray's edition (1678) of Willughby's "Ornithology" occurs the following passage as to the estimation in which the bustard was then held for the table:- "Though some discommend their flesh, yet with us it is esteemed both delicate and wholesome. Hence, but chiefly for its rarity, the bustard sells very dear, serving only to furnish Princes and great men's tables, at feasts and public entertainments."

Dr. Bree ("Field," 1867, p. 465) mentions his having partaken of a bustard in 1831, at Mr. Chad's, then British minister at Berlin, who had estates in Norfolk, from whence the bird had been procured, (a very long way for them to be sent in those days!) and most probably from some portion of the Swaffham tract, lying in the direction of Thursford. It was well-tasted, something between turkey and goose, "a rare union of gastronomic excellence." 
the interest taken in the subject by the late Sir William Hooker, I have had transmitted to me extracts from a journal kept by Mr. Hardy, which show that on May 6 th, 1801, he received a bustard's egg from Mr. Winner, of Litcham; on May 13th, 1802, two eggs from Mr. Sainty, of Heacham; as also, on June 10th, 1803, and June 7th, 1804. On October 26th, 1804, Mr. Hardy writes that he received a young male bustard from Lord Petre, who at that time owned the Buckenham estate, near Thetford. On May 30th, 1808, three eggs were sent him by Mr. Pratt (of Ryston?), and on November 8th, 1813, he received " a fine male bustard about six months old from George Turner, of Thetford." To all the entries of eggs, except the first, Mr. Hardy adds that he placed them under a hen immediately. With reference, also, to Mr. Hardy's birds, Yarrell ("Brit. Bds.," 3rd ed., vol. ii., p. 422) quotes the following passage from a note at the foot of page 197, in Bennett's edition of White's Selborne :- "'Two birds of this lind, male and female, have been kept in the garden ground belonging to the Norwich Infirmary, and have but lately been sold by the owner of them. The male bird was very beautiful and courageous, apparently afraid of nothing, seizing any one that came near him by the coat; yet, on the appearance of any small hawk high in the air, he would squat close to the ground, expressing strong signs of fear. The female was very shy." This, so-called, Norwich "Infirmary," however, as I have very recently ascertained, was no other than the Norfolk and Norwich Hospital, from whose archives it appears that Mr. George Hardy filled the office of house surgeon and apothecary to that institution from the year 1793 to 1826 , and it was, therefore, in the enclosure at the back of the Hospital that his experiments in hatehing and rearing bustards were carried on. In confirmation of the above I may add the following communication very kindly sent me 
by Mr. G. S. Kett, of Brooke, a former treasurer of the Hospital:- "I I perfectly well remember Mr. Hardy's bustards. He had them many years, and succeeded in making them quite domesticated. At one time I recollect his having three, if not four; they were beautiful birds, especially the adult ones, but they were sent away before I was treasurer to the Hospital. I understood they were dismissed in consequence of the male bird annoying the convalescent patients in the airing grounds. They had always the appearance of being very healthy, but I cannot say how Mr. Hardy first became possessed of them, or how he reared the young." The article in "Fraser's Magazine," for September, 1854, supposed to be written by the late Mr. Broderip, mentions a few other cases of tame bustards-three kept by the Duke of Queensberry on his lawn at Newmarket, and one possessed for a long time by Mr. Westall, of Risby, in Suffolk. Mr. Mac Took, a former owner of Sandringham, is also said to have kept a tame bustard,* and in his notes on this species, supplied to Mr. Yarrell, the Rev. R. Lubbock writes,

* A very fine male bird in Mr. Newcome's collection at Feltwell, was, until lately, in the possession of Lord Lilford, who received it alive from the Zoological Gardens at Brussels, having come originally, he believes, from Leipsic. This bird, which died in January, 1867, was preserved in perfect health for nearly four years, the only one his lordship has been able to keep in confinement more than a few months. "By nature," writes its former owner, "he was exceedingly bold and tame, and would approach any one who entered the aviary quite fearlessly, making a curious guttural noise almost impossible to describe. He ate mice, raw meat, worms, snails, wheat, barley, turnip-tops, lettuce, and grass, and lived amicably with other birds, godwits, a purple water-hen, bronzewinged pigeous, \&c., though he and a gold-pheasant cock had differences, and the latter was quite the master." The gular pouch was, I understand, found in this bird, when skinned by Leadbeater. 
"When a boy I remember two or three individuals in a domesticated state. I recollect one of these birds swallowing, in an instant, a thin leather glove which I dropped."

The local distribution of the bustard when an inhabitant of Norfolk, was, as may be gathered from the foregoing paragraphs, comprised within the boundaries of the "Breck" district;* indeed, scarcely any other part of the county was suited to their habits, and whilst their head-quarters were situated around Westacre and Thetford, the latter haunt, on the extreme southern limit of the county, immediately adjoined their chief stronghold in Suffolk, at Icklingham and Elveden. From the two centres as it were, already described, we trace them by the records of birds seen or killed, or of localities in which nests were occasionally discovered, diverging in all directions, yet rarely overstepping their prescribed bounds even when wandering in search of food during hard winters. The wide sandy "Denes," on the borders of the Wash, backed by rough marshes and running streams, were, no doubt, at all times, a favourite resort for their roving flocks at the close of the breeding season. Messrs. Sheppard and Whitear speak of having twice seen a male bustard in the neighbourhood of Burnham; and a male bird still preserved at Hillington Hall, near Lynn, was trapped at Docking, as ascertained by Mr. G. B. Ffolkes, more than fifty years ago. As I learn, also, from a communication received through my friend $\mathrm{Mr}$. G. G. Fowler, the late $\mathrm{Mr}$. William Ffolkes remembered, when a boy, having seen seven bustards, on several occasions, in the parish of Hillington; but these, from the desire of people at that time to procure specimens, were soon reduced to three hens, of which the last was the Dersingham bird, pur-

* Seo the "Introduction" to vol. i., p. xlviii. 
chased by Mr. Borrer, at Cambridge. Mr. Wood's bird, killed at Morston (a not rnlikely locality), had no doubt travelled beyond its ordinary beat, in search of those companions whose fate had been sealed before its own, and of other stragglers, not necessarily migrants, Mr. Lubbock states (1845) "some twenty-five years back several were observed in Wilby field, between Attleburgh and Harling, within twenty miles of Norwich." To refer, also, once more to the bird mentioned by the same author as "taken some fifty or sixty years back, at Sprowston, within two miles of this city, by means of greyhounds," it appears quite as probable, from the circumstances attending its capture-which occurred on a "very windy morning after" a tempestuous night" - that it had been caught by the gale and thus transferred from the western to the eastern side of the county, ${ }^{*}$ as that it had arrived as a foreign visitant on our coast through the same influences.

It is, however, as a migrant only that the bustard now holds a place in the list of Norfolk Birds; and, considering the range of this species on the continent at the present time, it is rather a matter of surprise that more stragglers should not reach the British Islands, described by Mr. Gould $\dagger$ as " their western

* In White's "Gazetteer of Norfolk" (3rd ed.), a certain locality adjoining the parish of Forncett St. Peter, some twelve miles from Norwich, is described as "Bustard's Green," but I cannot learn that there are any ornithological associations connected with it to account for its singular title.

+ Mr. Gould, in his "Birds of Great Britain," gives the particulars of eight migratory specimens killed in different parts of England since the species became extinct in this county. One, a female, at the Lizard, Cornwall, in March, 1843; another near St. Austell, in 1854; a female, in 1850, at Lydd, in Romney-marsh; another in the parish of Bratton-Clovelly, North Devon; a female at Leeshill, Cumberland, in March, 1854; one at Hungerford, in January, 1856 ; a young male at Rommey, in 1859 ; and in February, 
limit." On this point, moreover, Mr. Alfred Newton remarks, "There can be very little doubt that as long as the bustard exists as a native of France, Germany, and Sweden, we shall be subject to occasional visits of stragglers from one or other of those countries just as we always have been to visits of the smaller species (Otis tetrax.)" It is most probable that the bustard recorded by $\mathrm{Mr}$. Lubbock as killed at Palling some years back, was a foreigner, on a visit, perhaps, to its then surviving relatives, but this bird (an immature male), as I was informed by the late Rev. Edward Postle, who had had it for some years in his possession, was killed at Horsey, near Yarmouth, and not at Palling. Of its capture, Mr. Postle, in 1865, sent me the following very interesting particulars :- " It was killed, I should say, in 1820, at Horsey by the sea, and was seen to come off the sea and to drop into a turnip field, where it remained till a farmer, a relative of a friend of my father's, got his gun and shot it. It thus found its way into my father's collection at Colney." There is no record that I know of, either before or since that time, of any supposed migratory bustard on the Norfolk coast until the severe winter of 1866-7, when, a large bird (which, though not procured, belonged, I have no doubt to this species), was likewise observed in the Horsey marshes by Captain Rising, who thus recorded its occurrence in the

1861, one near York. To these may be added, also, one seen near Stonehenge by Mr. Waterhouse, 10th of August, 1849 ("Zool.," p. 2590); two which frequented Burwell Fen, in Cambridgeshire, from the end of January to the 1st of March, 1856 (“Zool.," pp. 5063, 5279); a female found dead in Bridlington Bay, Yorkshire, 11th November, 1864 ("Zool.," p. 9412); and a notice by a correspondent in the "Field" (April 14th, 1866, p. 317), of one seen, at that time, at Halton Holegate, in Lincolnshire; and a pair at Candlesby, in the same neighbourhood, a few years before. That is to say, one occurs in some part of England on an average in overy two years. 
"Field" (January 19th, 1867):-“As I was in my boat after wild fowl, on the 7 th instant, on Horseymere, I observed a large bird flying towards me. At first I mistook it for a heron, from its slow, steady flight, but on its nearer approach, I found out my mistake. The bird was coming directly over our heads, but bent its course when some sixty or seventy yards from us. We both fired, but the bird liept steadily on its way till we lost sight of it. I could not imagine what it was, never before having seen the great bustard on the wing; still, the peculiar round shape of the wing, jagged also at the edge, the neck, also, and head so small in comparison with the body, struck me much, and made me very anxious to get it. On the next two days it was seen again stalking in the marshes, like an over-grown turkey, but it would not allow any nearer approach than one hundred yards before it flew quietly away, taking, however, but short flights, for it seemed more careful than wild. Having now no doubt that the bird was the great bustard, I have been on the look out ever since, but when once the snow came the bird absconded." I may here mention, that in April, 1866, a rumour reached me, through the Rev. C. Norris, of Briston, of two very large and unknown birds "as big as turkeys," having been seen by some gunners at Wells-next-the-Sea, flying low over that district in a westerly direction. On further enquiry I was unable to elicit anything more definite than is here given, and should have scarcely considered the incident worth inserting, but for the fact that scarcely a week later I read in the "Field" the notice of a bustard having been observed in Lincolnshire (April 14th, 1866), as before stated in the list of migratory specimens.*

* The fact that the great bustard is a bird possessing the power of flight in a very high degree is one which has been too frequently orerlooked by many English authors. If proof of this be wanted it 
I have taken some pains to ascertain, as far as it is now possible to do so, the history of such Norfolk and Suffolk-killed bustards as are still preserved in public or private collections, and to this list of stuffed specimens I have also added a few particulars respecting well authenticated eggs, from both counties.

In the Norwich museum is a magnificent pair, presented by Mr. J. H. Gurney, in 1843, and an adult female, by Mr. Hill Leathes, in the following year. The former (Nos. 183 and 183a) in full adult plumage, were originally in the collection of Mr. John Scales, who has informed me that the male was found dead on Beacbamwell warren some time between 1815 and 1818, having been, it was believed, previously shot at and wounded at Narborough by Mr. R. Sanders, then on a visit to that place. The warreners were attracted to the spot where it lay by some crows, which had picked out the eye. It appeared to have been dead some two or three days, having been hit in the lower part of the body, and had become so putrid that $\mathrm{Mr}$. Scales had to remove a large piece of the skin. It, however, then weighed twenty-four pounds. The female was obtained in 1831, on Westacre-field, and was caught in one of about four dozen rabbit-traps, set by $\mathrm{Mr}$. Scales amongst the turnips. This bird weighed either sixteen or eighteen pounds. The history of the second female (No. 183b) is somewhat more doubtful, but the late $\mathrm{Mr}$. H. M. Leathes, in a letter to $\mathrm{Mr}$. Gurney in 1853, stated that

is to be found in the writings of most of the German ornithologists, but a very striking confirmation was also given by many of the newspaper correspondents with the Crimean army in the winter of 1855-6, when a large number of these birds suddenly appeared, it is said from the eastward, on the steppes between Sebastopol and Balaklava then occupied by the allied forces. A fine male then obtained is in the possession of Mr. Alfred Newton. 
it was obtained, he understood, by his cousin, the Rev. G. R. Leathes, as long ago as the year 1815, from Parker, then a gunsmith at Bury St. Edmund's, who asserted that it had been shot by a gamekeeper at Elveden, in Suffolk. If so, Mr. A. Newton believes it was killed before his father became possessed of that estate, and that one Cornel was most likely the slayer of it.

In Mr. Hamond's collection at Westacre Highhouse,* are a male and female, in one large case, of which the male bird, as Mr. Hamond informs me, came from Spain, $\dagger$ and the female, as I learn from Mr. Robert Elwes, is the one (before mentioned) shot by his father, Mr. Henry Elwes, at Congham, in 1831, and was stuffed by the Rev. H. Dugmore. In the same house are also four bustard's eggs, of which one is marked "Ash Breck, Westacre, 1836, taken by Richard Hamond." The three others are all believed to have been taken at Westacre at least thirty years ago.

In Mr. Robert Elwes' collection at Congham House, $\ddagger$ near Lynn, is by far the finest series of Norfolk, or even British bustards anywhere to be seen, comprising in

Nearly all the rarer birds in this fine collection were procured either in the Orkneys by the Rev. Henry Dugmore (by whom they were also mounted), or in the Low Countries by Mr. J. D. Hoy.

+ The pair of bustards, preserved at Wecting Hall, Norfolk, were brought from Spain, as Mr. A. Newton was informed, by the late General Angerstein.

\$ This very perfect collection of British birds, in a wonderful state of preservation, was formed by the late Rev. Robert Hamond, and most of the specimens were stuffed and mounted by himself. It was for many years in the possession of his sister, the late Miss Hamond, of Swafflam, at whose death it passed into the hands of its present owner; but, unfortunately, there is a want of authentic records as to the locality of most of the rarer specimens, though some were probably obtained in this county. The orioles, woodchats, a fine purple heron, and others, as Mr. Dugmore informs me, came from Holland. 
one large case, a magnificent male, two females, a young bird in nestling plumage, and two eggs, and in a separate case a third female and two more eg.gs.* All the birds in the large group, as I have recently ascertained, were procured and preserved by the Rev. R. Hamond, in the year $1820 ; \dagger$ and the particulars of their capture, so far as they can now be ascertained, $\ddagger$ appear to be as follows:One female was shot by a man at Westacre, who sold it to Mr. Hamond ; the other was picked up dead, by limself, shortly afterwards in a turnip field near Swaff ham, his dog having pointed it when ranging for other game, and the nestling was liatched out under a Turkey from one of two eggs, taken about the same time, on either Westacre or Massingham-field. The history of the male bird is somewhat more confused, owing, I believe, to two if not three having been lilled about the same time, which would account for certain discrepancies between Mr. Moor's account in the "Zoologist" and notes supplied to me by Mr. R. Elwes, Mr. Scales (who frequently assisted $\mathrm{Mr}$. Hamond in preserving his birds), and a former gamelieeper of $\mathrm{Mr}$. Hamond's, named Cater, now in his seventy-ninth year. There is no doubt, however, that this noble bird was shot at or near Westacre by Mr. Hamond himself, and, as proved by his own memorandum on the lithograph, in the year 1820. It is said to have weighed twenty-eight pounds.

* The late Mr. Selby came to Norfolk expressly to see and draw these birds, and the result will be found in his "Illustrations of British Oruithology," published in 1825 (vol. i., plates 64 and 64*).

† I am indebted to Mr. Alwin S. Bell, of Weymouth, for the sight of a lithograph, representing this group of bustards (see "Zoologist," s. s., p. 2103), which was presented by the Rev. R. Hamond in 1831 to Mr. Mr. Martin, of Rye, Sussex, and on the back of which, in Mr. Hamond's own writing, is an inscription stating that they were all shot and preserved in the year 1820.

\# See Mr. E. J. Moor's account of these birds in the "Zoologist," s. s. (p. 2024.) 
The female in the separate case is no doubt the one which, according to the late Miss Hamond, of Swafflam, was caught in the following manner by her father. They were driving in a pony carriage, when the bird was seen stealing through the rye, near the road side. It then crouched down, and Mr. Hamond, walking gently up, threw a jacket or spencer he had with him over the bird and secured it.

In the late Mr. Lombe's collection, now at Wymondham, in the possession of Mrs. E. P. Clarke, is a fine pair of bustards, but no record, unfortunately, exists as to the locality whence the male bird was procured. It was purchased for Mr. Lombe by Leadbeater many years ago, and is most probably a foreigner. The female, as Mrs. Clarke informs me, was presented to Mr. Lombe by the late Rev. Edward Evans, formerly rector of Eriswell, in Suffolk. This bird was kept as a pet by Mr. Evans, and used to come up to the windows of the house, or even into the brealifist room, to be fed, but its leg was unfortunately broken through a boy throwing a stick at it, when Mr. Evans had it killed, and presented it to Mr. Lombe.

In the Rev. C. J. Lucas's collection, at Burgh, near Yarmouth, is an adult female, recently purchased by him at a sale, at Sterens', in Covent-garden. I have had some difficulty in tracing out the history of this bird, but have at last succeeded in establishing its claims to be included at least in the list of East Anglian specimens. In the year 1810 , as shown by an entry in the "donation" book, an adult female bustard was purchased, by subscription, * for the Norwich Museum, there being at that time no other specimen in the collection. This bird was procured by the then secretary, $\mathbf{M r}$.

* The donors being Mr. J. H. Gurney and Mr. Thomas Brightwell, with the late Dr. Lubbock and Mr. George Morse.

F 2 
Richard Griffin* (now residing at Weymouth), from a bird-stuffer, named Bilson, at Bury St. Edmund's, whose son subsequently informed Mr. A. Newton that the bird in question had been brought to his father by a labouring man, and was killed near Lakenheath. From further enquiries made by $\mathrm{Mr}$. Newton, it would appear to have been one trapped at Eriswell, in Suffolk, about 1827 or 1829, by a man named Gathercole, and is, probably, the specimen mentioned by Bishop Stanley ("Familiar History of Birds," vol. ii., p. 3, 2nd ed.) as having been trapped at "Cresswell"-an obvious misprint for Eriswell, near Mildenhall. This female remained in the Norwich Museum until Mr. Scales's fine pair were presented by $\mathrm{Mr}$. J. H. Gurney, when, as a duplicate, it was exchanged for several foreign bird-skins, and thus passed into the hands of Mr. W. E. Cator, then an undergraduate of Queen's College, Cambridge, who subsequently parted with it to Mr. A. F. Sealy. During that gentleman's absence from England, in 1865, I first saw this bird in the charge of Mr. F. Barlow, of Cambridge, and recognised it at once when sent to Norwich by Mr. Lucas, in 1867, to be re-stuffed. On enquiry I ascertained from Mr. Lucas that he had lately purchased the bird in London, at the sale of part of Mr. Sealy's collection, consequent on his continued residence abroad. Mr. Knight, of Norwich, who has been for many years birdstuffer to the Norwich Museum, examined Mr. Lucas's bird at my request, and from the manner in which one leg had been mended with black cord, and other peculiarities, was perfectly sure of its identity with the original museum specimen.

The male bird killed at Horsey, since the death of

* In a letter lately received from MIr. Griffin confirming these particulars, that gentleman also adds that an egg, quite ready for exclusion, was taken from this bird, and was in his possession for some years, but he cannot now romomber what became of it. 
the Rev. Edward Postle, has passed into the hands of his brother, Mr. Henry Postle, of Witchingham; and the female procured at Lexham in 1838, is still preserved at Lexham Hall, as $\mathrm{Mr}$. Lubbock has recently ascertained. To these must be also added the Docking male, before mentioned, in the possession of Sir William Ffolkes, of Hillington Hall, which was trapped and afterwards stuffed by a farmer, named Norman, some fifty years ago.

At Riddlesworth Hall a female bustard has been long preserved, which Mr. Thornhill's father received from Cavenham, in Suffolk. At West Harling Hall are a pair of bustards, which, though bought by the late Lord Colborne as British specimens, were doubted by him to be so. At Clermont Lodge, Norfolk, it is believed there was until lately a stuffed bustard, which had probably been preserved there from the late Lord Clermont's time, and if so had doubtless been killed in the vicinity.

The collection of birds formerly belonging to the Philosophical Society of Cambridge, and about two years ago transferred to the University Museum, contains a female bustard, which I am informed by the Rev. R. Gwilt was obtained at Icklingham.*

The existence, at the present time, in good condition, of the bird recorded by Mr. Lubbock in 1845 as taken

* This same collection also contains two other British bustards, both killed in Cambridgeshire-one a male, supposed to be that recorded by Mr. Jenyns ("Man. Br. Vert. An.," p. 175) as shot near Ickleton in January, 1831, the other a female, said to havo been killed at Littleport. The specimen stated by Yarrell and others to have been killed near Caxton in December, 1832, and to be preserved in the same museum, is a little bustard (Otis tetrax)! (See Mr. H. 'Turner's note in “ Mag. Nat. Hist.," for 1833, p. 513; and Mr. Jenyns's work already quoted, p. 176.) A bustard's egg also in the collection was presented to the Philosophical Society in March, 1831, by Mr. Barron, as having been found in Cambridgo. shire. 
by greylom ds at Sprowston "some fifty or sixty years back," is in itself a fact of no little interest; and difficult as it has been to trace it in its many wanderings from one collection to another, it has given me no little satisfaction to discover it at last, where its value is so fully appreciated, in the possession of Lord Sondes, at Elmham. This specimen, a fine adult male, after its capture by Sir Lambert Blackwell's greyhounds, was preserved at Easton Lodge, near Norwich, where Sir Lambert then resided, and formed part of one of the oldest collections of stuffed birds in Norfoll. Here it was seen by Mr. Lubbock when a boy, as far back as the year 1809 or 1810, and was then in the possession of Sir Willian Foster's fither, to whom Sir Lambert Blackwell had left the estate and the contents of his house. Subsequently, as I am informed, the entire collection was removed to the residence of the late Fev. Lambert B. Foster, at Brundall, by whom it was sold by auction, on his ceasing to reside in Norfolk. At that time most of the birds were in a very bad condition, and amongst others this bustard required renovation, and was accordingly sent to Knight, of Norwich, to be "done up" for the next owner, the Rev. C. Humfrey, of Wroxham, who afterwards presented it, as Lord Sondes informs me, to the Rev. Charles Penrice, of Plumstead Hall. On the denth of that gentleman, and the dispersion of his collection in 1857, when, as I have before stated, the chief portion of his birds passed into my hands, * this bustard was presented by Major Penrice to Lady Sondes, and after having been again carefully restored by the late John Sayer, of Norwich, in whose shop I examined it, was placed in its latest resting place at Elmham Hall.

At Helmingham Hall, Suffolk, there is a case of

* See vol. i., p. 311, note, where this bird is, by mistake, described as a female. 
bustards, contilining specimens, which, in all probability, were killed in that county, but of their true history I can learn nothing conclusive, although the late Lady Middleton kindly interested herself in making enquirics respecting them.*

Besides the eggs already mentioned in the Westacre and Congham collections, Mr. Alfred Newton possesses one of the eggs (two pairs and a single one) laid by three females on Massingham-heath, in the spring of 1833, as before stated. This egg, as is shown by an inscription on it in Mr. Salmon's handwriting, was presented by him to the late Mr. Joln Wolley, and was by the latter left, with the rest of his magnificent oological collection, to Mr. Newton. Another of this same series of eggs, from Massingham, was also in Mr. Salmon's collection, bequeathed by him to the Limnean Society, but this, with many other of the rarer specimens, disappeared in a mysterious manner before the Society had been able to take possession of their valuable legacy. It formed the subject of the figure in the last edition (1866, pl. lxxiii., fig. 1) of Mr. Hewitson's well lnown work, and should it still be in existence, would probably be recognisable by its portrait.

A second egg in Mr. Alfred Newton's possession is marked "Great Massingham, Norfolk, probably about 1835 or 1836." The egg was purchased by Mr. Newton of $\mathrm{Mr}$. H. B. Rodwell, of Brancaster, who had received

* In a clever little work by the Rev. W. S. Symonds, entitled "Old Bones," it is mentioned (p. 70, 2nd ed.) that the Worcester Museum contains a pair of bustards "captured in Norfolk," and presented by the present Lord Lyttleton. All the enquiries I have been able to make have failed to furnish me with any further particulars respecting these specimens, except that they were stufted by Weaver, of Birmingham, and given to the museum in 1849, as I am informed by Mr. Reece, the secretary and curator, who believes that they were for some time in the late Lord Lyttleton's possession. 
it from his uncle, Mr. D'Urban Blyth, of Weasenham, who, in a letter written in 1856 , states that " some years since a bustard's nest was found at a farm adjoining mine, and the two egg's it contained came into my possession. One of them was, unfortunately, broken soon afterwards; the other I gave to my sister, Mrs. Rodwell, for one of her nephews." In further confirmation of the above, I may add the following note, very recently received from the Rev. Thomas Fulcher, of Old Buckenham:- "Three or four eggs of the great bustard were found at Great Massingham, Norfolk, on Mr. D'Urban Blyth's farm, in the years 1834 and 1835. I saw one of these eggs July 21st, 1837."

The egg figured in the first edition of Mr. Hewitson's work (pl. lxxxviii.)* was presented to him by Mr. C. W. Spurgeon, of Lynn, and was taken probably at Congham, but certainly in the Swaffham country. It is now in the collection of Mr. John Hancock, of Newcastle-onTyne. Another egg, taken at the same time, is now in the possession of Mr. C. Burlingham, of Lynn. They were both, as I learn through Mr. Southwell, obtained about the year 1833 by Mr. Beck, of Congham.

Mr. Scales possesses one presented to him by the late Rev. Robert Hamond, which was found in the neighbourhood of Westacre.

A single egg in the possession of Mr. Coldham, of Anmer, was taken many years back in Anmer field, but the date is unknown; and another in the Norwich Museum, was presented, with other eggs, by the late Mr. Salmon; but, unfortunately, there is no inscription upon it, nor any record in the "donation" book to fix its locality.

Mr. H. J. Elwes, of the Scots Fusilier Guards,

* Part twenty-two containing this plate, was published July 1st, 1835 ; the first edition was not completed till 1838. 
kindly informs me that he has a pair of bustards' eggs, which were procured in Norfoll by his grandfather, $\mathrm{Mr}$. Elwes, of Congham, and Colesborne, about the year 1830, for the Rev. J. Pitt, who subsequently presented them to him. He believes them to have been taken on Massingham heath.

A single egg in the possession of $\mathrm{Mr}$. Clarke, of North Wootton, has been satisfactorily established by Mr. Southwell, as a genuine Norfolk specimen, although its having been blown with two holes at the side, according to modern custom, seemed to mark it as of somewhat too recent date. This point has, however, been fully explained, and other interesting particulars respecting it obligingly communicated by Miss Charlotte St. John, formerly of Gayton Hall, in this County, who, in a letter to Mr. Southwell, remarks—“"The egg in question was given to me by the late Rev. Robert Hamond, I should think about forty years ago. It was found by him or his keeper Denny on Massingham heath, and I have a better remembrance of it from the circumstance that he sent it in a small beautifully-made coffin about a foot long. The egg was inside, wrapped up in cotton wool. I can easily explain the two holes at the side. Mr. Hamond blew it himself and always did so; but I blew mine at the two ends, a point on which we did not agree." This egg, therefore, formed part of Miss St. John's collection, which she presented about two years ago to the late Mrs. Barnes, of Gayton Hall, at whose death it passed into the hands of $\mathrm{Mr}$. Clarke as above stated. It is scarcely possible, at this distance of time, to ascertain the exact date when the egg was taken, but if, as appears by no means improbable, the little coffin so quaintly employed by Mr. Hamond as an egg shell, had some covert allusion to the gradual extinction of the bustard in Norfolk, Miss St. John is most likely correct in saying, that it was "about forty years ago." 
The Rev. R. Gwilt, of Iclilingham, Suffolk, informs me that he has two eggs, laid many years ago in that once noted district, and that a third, from the same locality, was presented some forty years since to Lady Wilson, of Hampstead.

A third egg in Mr. Alfied Newton's possession was bought by him in 1856, at the sale of Mr. Yarrell's collection. It had been taken many years before, as Mr. Yarrell once told $\mathrm{Mr}$. Newton, somewhere near Bury St. Edmund's.

The most beautiful representations of the bustard are to be found in Mr. Wolf's "Zoological Sketches" (1st Series, pl. 45) and Mr. Gould's "Birds of Great Britain" (part 5.) In both cases the figures are drawn from careful studies, by $\mathrm{Mr}$. Wolf, of birds which liave been kept alive in the gardens of the Zoological Society, and almost every posture assumed by the species is admirably delineated by that greatest master of animal portraiture.

\section{OTIS TETRAX, Linnæus.}

\section{LITTLE BUSTARD.}

Unlike the great bustard, whose history is almost inseparably comnected with that of the county, this species would seem to have passed ummoticed by Norfolk ornithologists until within the last forty or fifty years, and though Messrs. Sheppard and Whitear, in 1824, recorded two specimens as having been killed in Suffolk (one of them in November, 1804), they make no mention of its occurrence on the Norfolk coast. As more recent local authorities, also, content themselves with stating that it "has appeared in several instances," I am obliged to seek for the particulars of such specimens from other and private sources. The earliest of which 
I have any evidence is a bird in the collection of Lord Sondes, at Elmham Hall, which, as his Lordship has kindly informed me, was shot by his gamekeeper on some fenny land at Elmham, about the year 1822 or 1823. It is in full winter plumage, but the sex was not noted at the time.

Next, probably, in order of date are the two supposed females (Nos. 185a and 185b) in the Norwich museum, of which the first, as shown by the donation book, was presented by $\mathrm{Mr}$. William Primrose in 1847. This one is stated to have been killed at Trunch, but although the exact period of its capture is mknown, it is most likely, from its being already stuffed and "cased up" when placed in the museum, that it was procured some time prior to that event. The second, presented by the late Mr. Sparshall, in 184.3, was shot in a turnip field at Hellesdon, near Norwich; in 1835, according to an entry in the donation book, but in Mr. Lombe's* MS. notes the date of this specimen is given as December 3rd, 1833, which I have reason to believe is the more correct. Mr. Gurney remembers this bird in the possession of Mr. Sparshall, for some years before it was deposited in the museum collection.

About the year 1836, as recorded in Mr. Dowell's note book, a Little Bustard was killed at Morston, near Blakeney, by Mr. Wood, which is said to have been presented to the British museum; and, in reply to my enquiries, Mr. W. G. Wood, jun., furnished me with the following additional particulars:- "It was shot by my father more than thirty years ago. I think it was a female. Major Loftus had it, as he then hired both the Stiffkey and Morston shooting; it was killed in autumn." I have

* There are two fine specimens, male and female, in Mr. Lombe's collection, but no record exists as to the localities from whence he obtained them.

G 2 
been unable to trace this specimen, but it evidently did not, as above stated, find its way into the national collection. Mr. G. R. Gray, of the British museum, has very obligingly searched the records of donations about that period, and can find no reference to it, but, singularly enough, as will be seen by that gentleman's "Catalogue,"* one of the only two examples of the little bustard amongst the "British Birds" in that collection, is entered as killed in Norfolk. This one, a male in full summer plumage, cannot be confounded in any way with Mr. Wood's specimen obtained in the autumn, and is moreover known to have been purchased at the sale of $\mathrm{Mr}$. Bullock's celebrated museum. In an ammotated copy of Bullock's sale Catalogue, in the possession of Mr. A. Newton, I find (page 27) the following entry :- "Little Bustard, Otis tetrax, (male) extremely rare," to which the former owner of the catalogue (Mr. George Caley) has added in writing, "killed in Britain," with "Dr. Leach" as the name of the buyer, and $£ 10$ as the price. Dr. Leach, at that time, was keeper of the Zoological department of the British museum, but it will be noticed that in this entry no mention is made as to the precise locality, nor can I ascertain when, or on what authority, the bird was first ticketed "Norfolk." From the fact, however, that in every other known instance, this species has occurred on our coast late in autumn or during the winter months (a rule which pertains in other counties as well, according to Yarrell, who adds, " the male has never been killed here in the plumage assumed during the breeding season that I am aware of'), I am inclined to believe that this, after all, is no exception, and, even if "lilled in Britain," that Norfolk cannot fairly reckon it amongst its local rarities.

* "Catalogue of the British Birds in the collection of the British museum." By George Robert Gray, F.L.S., \&c., 1863, p. 134. 
In November, 1838, as I am informed by the Rev. Thomas Fulcher, a fine female in his possession was shot in a turnip-field, at Old Buckenham; and on the 21st of January, 1842, as I learn from Mr. Foster, of Wisbech, another female (as ascertained by dissection) was shot on one of the washes, near Welney, on the extreme western limits of the county. This bird, the one referred to by $\mathrm{Mr}$. Lubbock as killed near. Wisbech, is now in the museum of that town.

For the next ten years, I know of no other occurrence of this species either in Norfolk or Suffolk, but on the 29th of December, 1853, * a male in winter plumage, now in my possession, was shot during very severe weather, in a turnip-field, by the road side between Winterton and Yarmouth. This bird, which was brought to me in the flesh, was in good condition, the stomach literally crammed with regetable matter', apparently fragments of some large leaf with a rough surface and a serrated edge. Several others were also killed about the same time in different counties in England, as recorded in the "Zoologist" for 1854.

Again, on the 4th of March, 1858, a fine adult female, which was purchased by Mr. J. H. Gurney, was shot in the Southtown marshes, at Gorlestun, near Yarmouth. This bird was also in fine condition, the stomach filled with various kinds of green food, by far the larger portion consisting of a long fine grass, apparently from the marshes, having a brackish odour, and mixed with this, and matted together, was a species of Conferva from the ditches. Two flowers of the common daisy (Bellis perennis) were plainly discernable, as also a narrow scolloped leaf, resembling cat's-ear' (Hypochoris glabra), and besides these a small fragment of the water-ranunculus (Ranunculus aquatitis), were all

* The same recorded by Morris ("British Birds," vol. iv., p. 8.) 
that could be identified. The eggs in the ovaries, about the size of pins' heads, were easily distinguishable, being perfectly white. The weather, as in the previous instance, was intensely cold at the time, with snow on the ground.

To the Rev. C. W. Bagot, of Castle Rising, I am indebted for the notice of a specimen in his possession, which was killed in that neighbourhood early in the autumn of 1860 . The sex of this bird, which was stuffed by Mr. Baker, of Downham, was not noted at the time, but, like most of the specimens obtained in this county, it was killed in a turnip-field, by a gamekeeper, who mistook it, as it rose, for a young guinea-fowl. On November 29th of the same year another, which proved to be a female, was also killed in a turnip-field, at Norton Subcorse, near Loddon,* and was preserved by Knight of Norwich, for Mr. J. Wigg of that place. In the latter instance, although appearing during somewhat mild weather, this straggler preceded only by a week or two the intensely severe frosts of the two following months, during which time two others occurred in the adjoining counties of Suffolk and Essex.

Last in the list to the present time, is a specimen killed at Thetford, for the knowledge of which and the following particulars respecting it, I am indebted to my friend Mr. John Flower, of Croydon:- "It was first seen in a field adjoining $\mathrm{Mr}$. Bartlett's land, about Christmas, 1861. It was shot at by some one from Thetford, and missed. It then went on to the warren, a bare tract of land of about three thousand acres, where it was caught in a rabbit-trap. Mr. Bartlett had it stuffed and gave it to his father-in-law, Mr. Fuller, of Beachamwell, at whose death, a year or two ago, it

* Not Reedham, as erroneously stated by myself in the "Zoologist," p. 7315. 
again passed into Mr. Bartlett's possession. The sex of this specimen was not ascertained, but like the rest it is of course in winter plumage. The river Thet being the boundary between the two counties, this bird was in point of fact lilled in Suffolk, but having wandered. from place to place before its capture, it certainly deserves notice in the present work.

After recording such a series of local specimens, one may safely class the little bustard amongst those rarer migrants, which can be confidently looked for from time to time, and, from the regularity of its appearance during certain months of the year only, it may be reckoned as an occasional winter visitant. Whether occurring, also, as early as September or as late as March, the severity of the seison seems, in most cases, to have accounted for the appearance of this species, driven at the same time by contrary winds thus far to the westward of its ordinary course. Whether males or females actually predominate it is impossible to determine, since only in three instances have we the actual test of dissection, viz., in the Wisbech, $\mathbf{M r}$. Gurney's, and my own specimen. But on comparing my male bird with Mr. Gurney's female, both in full winter plumage, I find the only perceptible difference is in the depth of colouring generally. In the hen bird, all the darker markings are more defined, the margins to the feathers on the throat and breast, the bars on the tail, and the spots on the flanks, being broader and deeper in tint, than in my own specimen.* At the same time, there is far less difference between my bird and the supposed females in the Norwich museum (the Trunch

* I have lately examined two specimens of the little bustard, in the University Museum at Cambridge, both marked females, and in winter plumage, one of which is identical in colour and markings with my own, and presents, I imagine, the ordinary plumage of the young male in its first autumn. 
bird more particularly), which after all may have been described as females under the impression that a far greater sexual difference existed during the winter season.

The little bustard breeds abundantly in some parts of France, but in Germany, singularly enough, it is only known, as in our own country, as an annual winter visitant, though irregular in the time and place of its occurrence.

\section{CURSORIUS EUROP I US, Latham.}

\section{CREAM-COLOURED COURSER.}

This very rare straggler, from more southern climes, has not hitherto been included amongst our accidental visitants, but having been lilled once in the adjoining county, ${ }^{*}$ and observed on two separate occasions in

* In the "Magazine of Natural History" for 1831 (vol. iv., p. 163), in "A list of scarce birds killed in Suffolk since the autumn of 1827, sent as addenda to the list of Mr. J. D. Hoy, of Stokeby-Nayland (vol. iii., p. 436)," Mr. Edward Acton, of Grundisburgh, states that a bird of this species was " shot at Freston, near Aldborough, on October 3rd, 1828, by a shepherd of the name of Smith," and this specimen is believed by Dr. Bree ("Field," 1867, vol. xxx., p. 465) to be the one preserved in the late Mr. Hoy's collection, at Boile's court, near Brentwood, the case containing Mr. Hoy's bird, being labelled, "shot in 1828." This example is not mentioned by Yarrell, but in the five instances given by that author of the occurrence of the cream-coloured courser in England -one in East Kent, which is now in the British museum, and was figured and described by Latham in the first supplement to his "General Synopsis of Birds" (pl. 116, p. 264), published in 1787, and said (see "Zool. Jour.," iii., p. 493, and "Naturalist," 1837, vol., i., p. 133) to have been purchased subsequently by Donovan for eighty-thee guineus; one in North Wales in 1793; one at Wetherby 
Norfolk by very reliable witnesses, I think it may be now fairly included in the present list. The first intimation of the probability of this bird having appeared on our coast was given me by the Rev. E. W. Dowell, who writes, "in the autumn of $1817, \mathrm{Mr}$. Wood, of Morston, near Blakeney, told me that there was a strange bird frequenting his fields, something like a plover, which ran very fast. He had seen it for several days, and it appeared very tame, but, although I went after it at once, of course it was gone. From Mr. Wood's description, I had no difficulty in recognising this bird as the Creamcoloured Courser." To this statement I may add that Mr. Wood is well acquainted with all the ordinary forms of plover, Tringe, and other shore-birds frequenting that portion of the coast, and but for some marked peculiarity in this instance would not have informed Mr. Dowell of the supposed rarity. Still more recently Mr. Anthony Hamond, jun., pointed out to me a field near the roadside, at Westacre, in which a bird, exactly answering the description of the cream-coloured courser, was seen both by himself and his father on several occasions, as they drove past. This was in the autumn of 1855 or 1856 , but from a recent fall out hunting, he was unable to go after it with his gun, and his father,

in April, 1816; one in Leicestershire in October, 1827; and one on Eastdown, Salisbury Plain, in October, 1855; as well as those since recorded-two seen and one killed, at Braunton, in Devonshire, October, 1856 ("Zool.," 5346), one killed in Hackney marshes, October 19th, 1857 ("Zool.," 6309); and one near Maryport, October, 186t ("Zool.," 9418)-it is worthy of note that, although said to be a scarce migrant even in the south of Europe, this species has appeared less frequently (including the two Norfulk examples), in the south of England, than in counties further to tho north. In every instance but one (April), also, where the date is known, this species has occurred in autumn, not less than six having been seen or killed in October. 
therefore, at last tried a chance shot at it from their vehicle, when the bird, though badly hit, flew too far for them to mark it down, and was never seen again. It was generally observed in company with a few peewits, frequenting the same spot, and after carefully watching it once or twice, within easy range, and afterwards consulting the figures in Yarrell and other authors, no doubt whatever existed in their minds as to the identity of the species.

So little is really known as to the true habitat of this rare migrant that $I$ do not hesitate to supplement my present notice of it with an extract from a paper on "Recent discoveries in European Oology," published by Mr. Hewitson in the "Ibis" for 1859 (vol. i., p. 79) :*"For the discovery of its eggs," writes Mr. Hewitson, "ornithologists are indebted to the Rev. H. B. Tristram, who has kindly sent me the following notes: 'Although during the winter of $1856-57$ I penetrated several hundred miles into the Algerian Sahara, and beyond its limits as far as between latitude $31^{\circ}$ and $30^{\circ}$, yet this bird only once came under my observation, being evidently for the most part only a summer migrant to those regions. In the month of June, 1857, I twice met with small flocks of them on the liauts plateaux between Biskra and Batna, to the south of Constantine. During the previous summer of 1856 , I had met with the bird several times in the western Sahara, north of Laghouat, and especially in the neighbourhood of Ain Oosera, a solitary caravansary in the desert kept up by the French government as a military halting-place. Though certain that the birds were breeding there at the time, I was unable to detect their nests; but shortly after my

* See also Mr. Osbert Salvin's remarks on this species, as observed by him in the Eastern Atlas, near Constantino, "Ibis," 1859 , p. 354 . 
departure, the keeper of the caravansary, who had assisted me in my search, and who had in previous years frequently taken the eggrs, and cooked them as omelets along with those of the Pterocles setarius, found the nest and sent me the eggrs, three in number. According to his account, the courser always adheres to this number, as indeed might have been expected from the character of the bird. It makes no nest whatever, but deposits its eggrs on the bare soil in the most arid plains.",

Since the above dates, however, several collectors in this comtry have received eggs from Algeria and Morocco.

\section{CEDCNEMUS CREPITANS, Temm.}

\section{STONE-CURLEW.}

The Great Plover, Stone-Curlew or "Culloo" as the name is locally pronounced, has also a special claim to its title of "Norfolk" plover (independently of its former abundance in this county), inasmuch as this bird appears to have been first made known, in a graphic form,* to British ornithologists by Sir Thomas Browne, who about the year 167.4 forwarded a drawing of it to the

* The first mention of this bird as British is by Christopher Merrett in his "Pinax Rerum Naturalium," Londini: 1667, 8vo., pp. 224, wherein we find (p. 182) as follows:--"Arquata congener, a stone-curlicw huic rostrum breve, accipitrinum [!], penno milvi, Phasiano par magnitudine, Dilicatissimæ avis ex agro Hantoniensi, Ds. Irutefinson, Ornithopola Londinensis." Stone-curlew is, of course, by far the oldest English name for the European "thicknee," and as we have eridence of its use both in Hampshire and Norfolk for two hundred years, it is much to be regretted that it has not been generally adopted by all British ornithologists.

H 2 
celebrated John Ray, taken from a specimen killed near Thetford,* and from which no doubt the figure in Willughloy's "Ornithology" (Tab. lxxvii.) was engraved. Sir Thomas also, in his list of Norfolk birds, describes this species as "a handsome tall bird remarkably eyed, and with a bill not above two inches long; commonly called a stone-curlew, but the note thereof more resembles that of a green plover, and breeds about Thetford, about the stones and shingles of the river." But although at that time, as at the present day, this species was most numerous in the western and south-

* I am greatly indebted to the Rev. H. B. Tristram for the sight of a very scarce little work, entitled-"A Collection of English Words not generally used. * * * With Catalogues of English Birds and Fishes. By John Ray, Fellow of the Royal Society." London, 1674, 8vo., pp. 178. In the preface, with reference to the "catalogue of English birds," occurs the following passage:- "Sinco this catalogne was sent away to the press, among some pictures of birds which I have received from the learned and deservedly famous Sir Thomas Browne, of Norwich, I find two or three English birds by me omitted, as whereof I was not certain. EEdicnemus Bellonii by him also first observed in England. Upon the picturo of it sent to me by Sir Thomas, I find inscribed 'a stone-curlew, from about Thetford, whereabouts they breed. It hath a remarkable eye and note somewhat like a green plover." "In Ray's preface to Willughlby's "Ornithology," Sir Thomas's contributions are also duly acknowledged, but from the following extract from a letter of that learned physician to his son Edward, dated March 28th, 1682 (see Wilkin's edition of his works, vol. i., p. 337), we find the former complaining of the unnecessary detention of his drawings:- "When Mr. Ray (he writes) was to print his ornithologie or description of birds, I lent him many dranghts of birds in colours, which I had cansed at times to bee drawne, and hee and Sir Phillip Skippon promised mee that they should be safely returned; butt I have not since received them. Butt they were left in Mr. Martyn's hands, therefore present my services unto Mr. Martyn (bookseller, at the bell, St. Paul's churchyard), and desire him from mee, to deliver the same unto you, and I shall rest satisfied." 
western parts of the county, yet judging from the localities in which a few scattered pairs are still met with, during the breeding season, in the neighbourhood of Norwich, it seems strange that Sir Thomas should not have obtained a specimen, for his purpose, much nearer home.

Like its big cousin the great bustard, though by no means in the same degree, the stone-curlew, even as a summer visitant, has been affected by those vast agricultural changes which, dating back from the commencement of the present century, have changed so materially the general aspect of the country and contracted everywhere the boundaries of the heath and the fen. As a ground breeder, also, its egrgs are peculiarly liable to accident, and this, combined with the wholesale system of egging pursued of late years, might alone account for the diminution of a species which, laying only two egg's at a time, is necessarily limited in its powers of reproduction. Compared, however, with the wild open tracts of the "Breck" district, the easterm side of the county can at no time have possessed the same amount of attraction for these birds, as even the former locality continues to afford; whilst the enclosure, on all sides, of heaths and commons, and the rapid growth of plantations on our once bleak soils, is fast depriving them, both towards the north and east, of the few haunts once favourable to their retiring habits.

In the immediate neighbourhood of Norwich, as at Costessy, Easton, and Bowthorpe, the stone-curlew, until within the last twenty or five and twenty years, bred regularly on the higher grounds, frequenting for that purpose certain large open fields, to which even here the term "Breck" is not uncommonly applied, whilst at Thorpe one or two pairs are still met with every spring. Tracing out, however, on the map, the localities from whence I have known either birds or eggs procured 
during the last few years in East Norfoll, this species would seem, at the present time, to be confined almost entirely to the wild hilly country lying to the westward of Cromer, within the "Cliff" district, and that still extensive, though not continuous, line of heaths and common lands, which, commencing about Rackheath, Mousehold and Thorpe, to the north of this city, proceeds in a north-westerly direction till it joins on to the former tract again about Hempstead and Holt. Here, and more particularly at Hempstead, as my friend $\mathrm{Mr}$. Elwards informs me, they were extremely numerous some thirty years ago, when a large extent of young plantations afforded both food and shelter* amongst the young trees, and whence these birds might be flushed in flocks of from forty to fifty at a time at the close of the breeding season. Although difficult enough of approach in their usually open haunts, it was easy enough under these circumstanees, to obtain shots at them, by sending one gun forward to the end of the planting, and many were, no doubt, killed in this mamer when little thought was given to their eventual scarcity. The system of egging, also, as then pursued, could not fail in some degree to show its effects, but the gradual though

* Mr. Lubbock particularly mentions the partiality of this species for recently formed coverts, remarking that " the greatest allurement to them is an extensive new plantation made in the open country, and on the improved plan of double trenching the soil. The loosened ground affords better means of obtaining worms and beetles, their usual food, and the birds appear particularly to delight in the partial concealment which the young trees afford in the first year or two; as soon as the trees attain any size all attraction ceases." In the spring of 1867, when driving with Mr. Anthony Hamond, jum., through a roadway dividing a recently formed plantation, adjoining Mrr. Elwes's residence at Congham, we disturbed a pair of these birds, which ran on for some distance, but at last rose and alighted again anongst the dwarf fir-trees. 
certain decrease in their numbers, is attributable mainly, no doubt, to the altered character of the locality when those young trees had lost their attractions, and developed into extensive and thickly planted woods. Yet to show the extruordinary attachment of these curlews to their accustomed breeding grounds, Mr. Hewitson ("Brit. Bds.' Eggs," 3rd ed.), on the authority of $\mathrm{Mr}$. Alfred Newton, states that "a particular spot where a pair of birds of this species had been accustomed to breed was resorted to by them for that purpose, long after it, and many acres around it, were planted with trees, and had become the centre of a flourishing wood."*

Once or twice, within the last four or five years, I have seen small flights of stone-curlews between Sherringham and Salthouse, during the months of June and July; and Mr. T. W. Cremer, of Beeston, near Cromer, informs me that a pair or two have hitherto bred, yearly, on some furze-covered hills at the back of his residence, where the poor of the purish have rights of commonage, but having neither heard nor seen them during the past summer (1867), he is doubtful whether they still continue to do so. About four years ago the Rev. C. Norris, of Briston, had eggs of this plover, taken on some rough ground not far from his house, but states that they have ceased for some time to breed on Bristoncommon, now about to be enclosed. A young bird was, however, taken in the summer of 1867 , in the vicinity of Holt, about three miles from Briston; and a couple of eggs said to have been found at Carston, near Aylsham, were shown me in the spring; and an adult bird and eggs from Witchingham. In August of the

* Mr. Nerrton has since told me that this took place in the warren-covert at Elveden, which extends over moro than threo hundred acres. 
same year, a female was shot at Rackheath; and in September a male at East Tuddenham; and on the 11th of October I was shown one said to have been run down in the vicinity of Norwich, which, most probably, came from Thorpe, as, on the 2nd of August, 1866, a specimen was also killed near this city, and one in the following month on the Rackheath estate,

Mr. Charles Jecks, of the Woodlands, Thorpe, informs me that for more than twenty years he has known a pair or two return in the spring to the same portions of that elevated plateau, where the stony soil is well suited to their habits. For several seasons they have bred, by the side of a plantation, within two hundred yards of his house, and having a naturalist's relish for their wild musical "clamour" at night, he takes every precaution to prevent their being disturbed. In the summer of 1866, young ones were hatched early in May, but as soon as these are able to fly, old and young together quit that neighbourhood, and, wandering in search of food beyond those friendly boundaries, too often lose one or more of their party, by a chance shot, before the time for migration arrives. Any how their numbers have never increased.

Mr. Lubbock, in a recent letter from Eccles, near Attleburgh, says, "In my vicinity the great-plover is following the bustard. Twenty years back I could hear them every summer evening from my parlour when the window was open. I have seen only one in the parish for the last four years." Passing, on, however, further to the south and west of the county, we come at once to the "Breck" district, which from time immemorial has been their chief resort, and where in many places they still remain plentiful, although elsewhere agricultural and other changes have had their effects. The latter is more particularly observable in the neighbourhood of Swaffham, where of late years they 


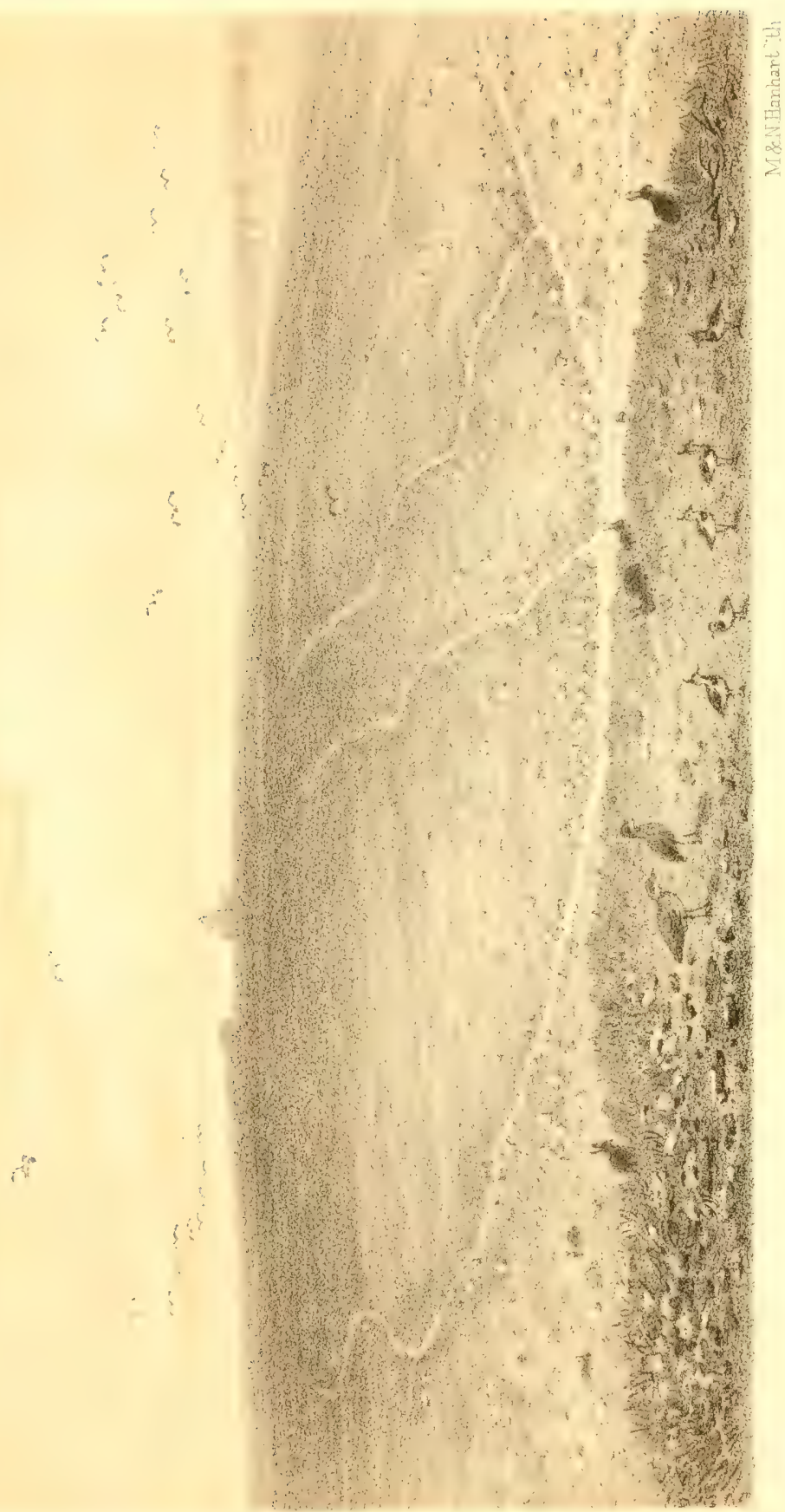

? 

have diminished considerably, but a few still breed annually about Westacre, Congham, and Lexham; and their eggs have been taken recently near Cressingham and Watton. At West Harling, though not in their former abundance, Mr. Ringer informs me that he has the last year or two met with from fifteen to twenty in a flock, frequenting the turnip-fields in the early autumn; and this, in spite of the great extent of wood that has grown up on all sides in that district. From Thetford, their main stronghold,* as in days gone by, Mr. Bartlett writes, "I do not think the stone-curlew has decreased since I have been here, some twenty years. I see as many as ever, but plantations have got up in the neighbourhood year by year, tending to take from its wildness, and so diminish both the curlew and ring-dotterel. On my warren they are quite as numerous, when the season is favourable, but its bleakness is undiminished." From the Feltwell country, also, I hear the same satisfactory account from my friend Mr. Newcome, who states that in the autumn of 1867 he saw about a hundred and fifty in one flock on his own estate. From these facts, then, we may conclude that if, on the eastern side of the county the stonecurlew, in a few years time, should cease to be reckoned amongst our summer visitants, there is little fear that as regards the southern and western portions, its presence in summer will still enliven the waste for many generations to come.

* Mr. Hervitson is quite in error as to the position of this district, when alluding ("Brit. Bds.' Eggs," 3rd ed.) to the abundance of the stone-curlew in Norfolk and Suffolk, he says, "It breeds upon the extensive sandy flats, which chiefly border upon the sea-shore." The flat sandy borders of the Wash, are not, nor do I think ever were, frequented by this species, which prefers a more hilly country; and Thetford warren, though many miles inland, has attractions not only for the great-plover, but for its more marine relative, the ring-dotterel (Charadrius hiaticula.) 
The arrival of these birds in spring occurs generally about the second week in April, when an occasional straggler may be found on the sea-shore, as on April 17th, 1866, when a single stone-emrlew was shot on Yarmonth beach. In that neighbourhood, however, as stated by the Messrs. Paget, it is but rarely met with. There is no "nest," but the two egrgs are laid on the bare ground, which, being of a light nature, becomes worn into a shallow depression by the movements of the sitting bird; and so much do the general tints of the eggs assimilate to those of the sandy soil around that the novice finds as much difficulty in detecting them as those of the ring-dotterel on a shingly beach. The eggs vary extremely in the disposition and colour of their markings, as shown by the three examples figured by Hewitson ("Brit. Bds.' Eggs," 3rd ed.), two taken from specimens in the late Mr. Salmon's collection; and a third from that of Mr. Alfred Newton, who possesses a wonderful series from the Thetford country, which exhibits very many beautiful and unusual varieties. Both parents would seem to share in the work of incubation, as Mr. Salmon on one occasion ascertained, by dissection, that several birds snared on their nests during the day time were all males. Whether, if undisturbed, they have more than one brood in the season I am unable to say, but if the first nest is robbed other eggs will be met with in a fresh state, up to a very late period, as, on the 11th of September, 1851, Mr. Dowell and Mr. Lubbock, when shooting at Harling;, found two eggs of the stone-curlew, the old birds rising not far off; and on the 9 th of October the parents were seen again, but the eggs had been taken. The young in their first down are pretty little creatures, and, when squatting to avoid detection, are as difficult to find as the eggs. They follow their parents in search of food, almost from their birth, hiding amongst the loose stones on the least appearance of danger, and a very 
marked attachment exists between old and young, of which Mr. Lubbock, in his "Fauna," gives a curious instance. An old bird, which had been shot at and slightly wounded in the pinion, having been turned loose into a walled-in garden, became exceedingly clamorous at sumrise, the following morning, and thus attracted a young one to the place of its confinement. This, after some difficulty, was also captured, and exhibited the greatest satisfaction at regaining its parent, seemingly quite indifferent to its own liberty. In June and July old and young together are frequently flushed from the turnips in the vicinity of their breeding grounds, and previous to their departure in October they collect together in considerable numbers; in some places, as before stated, amounting to over a hundred in a flock, and in former times probably as many more. Although the main body, however, leave us thus early in the autumn, stragglers are not unfrequently observed during the winter months, and at times, when the mildness of the season can in no way be alleged as the cause of their remaining so late. Mr. Salmon, in his notes on this species ("Mag. Nat. Hist.," 1836, p. 524), alluding to their usual departure in October, remarks-" Should the weather continue open a few will remain to a much later period," and instances his having "started one as late as the 9th of December, in the autumn of 1834." Mr. Lubbock also says, "It stays very late before it migrates; in mild seasons to the very end of November, and even into December." On the 15th of December, 1846, as recorded by Messrs. Gurney and Fisher ("Zoologist," 1847, p. 1601), a single bird was killed at Ludham, and the following instances have since come under my own notice :-

1851. On December 4th, during severe frost and snow, a great-plover, in good condition, was shot at Potter Heigham. 
1852. On February 3rd, weather mild at the time, another bird, shot near Cromer, was shown me in the flesh.

1853. On February 2nd, during frost and snow, a pair were lilled at Yoxford, in Suffolk; and Mr. L. H. Irby records in the "Zoologist" for this year (p. 3909), the occurrence of a pair at Thetford, early in March, with deep snow on the ground at the time.

1857. On December 5th, a young bird was caught alive at Hellesdon; weather mild.

1861. On November 11th, one was killed out of a small flock at Horsford, severe frost having set in on the 1st, with snow on the ground.

1864. On November 3rd, weather open, an adult bird was shot at Great Melton, near Wymondham.

1867. On December 18th, one was seen by Mr.J.H. Gurney in Leadenhall market, which had been sent up, with other birds, from the neighbourhood of Yarmouth.

From the above cases, then, it appears that, quite irrespective of atmospheric influences, individuals of this species occasionally remain with us throughout the winter; for it seems more reasonable to suppose that birds, lilled during severe frosts, in the month of February,* had never attempted to migrate, than that

* Montagu, in the "Supplement" to his "Ornithological Dictionary," gives an instance of a Norfolk plover having been killed in South Devon, in the beginning of February, 1807; whilst another was shot near the same place, about a fortnight before, in that " unusually mild winter." Gilbert White also states that this species was heard to pipe on the 27th of February, 1788, and that others were heard passing over head, by night, on the 1st of March. The regular occurrence of this bird during the winter months, in Cornwall, though unknown in that county in summer, has been several times specially noticed by Mr. E. H. Rodd in the "Zoologist" for 1845 (p. 876), 1818 (p. 2023), and 1866 (p. 3.) ; as well as by a correspondent in the "Field" of January 19th, 1867. In the latter publication, also, under date of January 
they should return northward, in such weather, at an unusually early period.

My own opportunities of observing this species have been somewhat limited, but in May, 1864, in company with $m y$ friend $\mathrm{Mr}$. Dix (who, as a resident at that time at West Harling, was well acquainted with their haunts), I had every facility, with the help of a good glass, for studying their habits in a wild state. In that neighbourhood, on the open "Brecks," the eggs are usually laid on some slightly rising ground, whence a good look out is kept, and where it is almost impossible to come upon the birds by surprise. If the exact spot is known, long before any near approach can be made, the old bird may be seen to rise slowly to its feet, and with arched back, like a French partridge, walk slowly off for a few yards, when, if further pressed, the pace quickens, and joined probably by its mate, from you know not where - so like are their tints to the surrounding soil-the pair rise on the wing, and with a strong quick flight, and outstretched legs, betake themselves to some distant part of the field, uttering at intervals their lond tremulous whistle. As ground-breeders they are necessarily exposed to many dangers, their eggs being so generally taken when discovered, and though carrion-crows are scarce in this game-preserving county, the rooks, especially in dry seasons, are scarcely less active as egg stealers. In this respect $\mathrm{Mr}$. Dix considers that the eggs are safer when laid in the middle of a wide open field, than, as is often the case, when situated within some fifty yards of a large fir "slip" or planta-

12th, 1867, a single bird is recorded as haring been killed at Charmouth, Dorset, on the 4th. 'To these may be added the still moro strange occurrence of a solitary specimen in Fifeshire, on the 27th of January, 1858, as stated by Mr. W. P. Turnbull in his "Birds of East Lothiau," which, according to that author, is the only one known to have appeared in that locality. 
tion.* In the former case he has known the curlew fight off the rook when suspiciously approaching its treasures; on the other hand the rook, quietly perched on the trees, watches the curlew leave her nest, and at once descends to plunder it. The shepherds, when driving their sheep on to the lands, always mark the spot where the curlew rises, and, by her alertness or not in doing so, judge whether the eggrs are fresh or set upon. Nearly all the eggss $\mathrm{Mr}$. Dix has had brought to him at different times have been taken in this way by the shepherds or their luds, but when a single sheep has approached too near to a nest he lias seen the old bird flutter its wings, and thus, by menacing attitudes, attempt to drive off the intruder.

Unless sought for, or come upon accidentally in their wild launts, these birds are but rarely heard or seen during the day, but towards evening they become exceedingly clamorous, and as nocturnal feeders chiefly, as evidenced by the large prominent eye, $\dagger$ their loud

* On the 16th of May, 1567, Mr. Anthony Hamond, jun., pointed out to me a nest with two eggs, placed within about fifty or sixty yards of a plantation, which bordered one side of a large field at Westacre. The birds ran off on our approach, and were soon lost sight of amongst the underwood.

† Thompson, in his "Birds of Ireland" (vol, ii., p. 83), states that a great plover, in the gardens of the Zoological Society, in London, greatly interested him, on various occasions, by its always remaining "fixed as a statue," so long as he had patience to return its gaze, and this in whatever attitude it chanced to be when his eye and the bird's first met. "I tried it," he says, "from different sides of the aviary, and found its performance the same from all. The earnestly fixed gaze of its large and prominent dark eye had a very singular effect." And this, no doubt, is its habit in a wild state, when, standing sentinel, as it were, on some slight elevation, it looks out far and near over its desert home, since, motionless as a statue, and in colour assimilating so closely to the soil, it may easily escape detection, by even a good observer. The chief peculiarity of this custom of the curlew is that the bird 
vibratory whistle may be heard at all hours of the night. By moonlight their cries become even more incessant, and amongst many treasured recollections of rural sights and somds, is the delight with which, on the 21st of Miry, 1861, I first heard them, at TVest Harling, under cireumstances peculiarly favourable to a listing impression, for

"Summer was the time, and sweet the hour."

when, long after midnight, I still sat listening at my open wiridow as, borne on the soft breeze from the neighbouring "Breck" lands, their tremulous notes blended with the wail of the lapwing; and, in strange contrast to such wild melody, the rich soft notes of the nightingale came up from the garden, whilst the air was filled with the scent of the honeysuckle, and paths, shrubs, and buildings, shone white in the reflection of the full moon.

Whether or not these birds, as stated by some authors, leave the uplands towards evening, and seek food and water in the low meadows, I camot say, but in this instance, undoubtedly, the cries of the curlews came from the same lands where I had observed them during the day. Besides insects, chiefly Coleopter, they are said to feed on snails, sluys, and worms ; * and Messus. Gurney and Fisher mention the forceps of several earwig's, as found by them in the stomach of one specimen. Another dissected lately by Mr. T. E. Gumn, contained some fibrous matter, mixed with fragments of coleopterous insects, and a few small pebbles.

always faces the spectator, and prosents the smallest surface to his eye. To follow the movements of the intruder, the bird moves its feet very rapidly, not altering its relative position, but just as the "pivot man" of a line of soldiers does.

* Mrr. Nerrcome tells me that the warreners say that when they find the curlew caught in traps, they also find frogs which they hare "spued up." 
The late Mr. J. D. Hoy, in a letter to Mr. Yarrell, alluding to the abundance of this species on the sandy plains of Norfolk, remarks, "great numbers have been caught in most seasons by the subscription heron hawks, at Didlington Hall; they have been known to take refuge in a rabbit-burrow when pursued by the lawk." But, as compared with the common curlew (Numenius arquata), the great plover is described by the authors of "Falconry in the British Isles" (p. 66) as reluctant to " take the air," and usually showing but little sport.

\section{GLAREOLA TORQUATA, Meyer.}

\section{COLLARED PRATINCOLE.}

This rare straggler is recorded as having occurred several times in this county, but I have been unable to ascertain authentic particulars of more than three or, at most, four specimens.

In the month of May, 1827,* as stated by the Messrs. Paget, a pair of Pratincoles were shot on Breydon-

* In a letter, written by Mr. J. D. Hoy to the late Mr. Selby, published by Dr. Bree in the "Field" of November 9th, 1867 (p. 385), with other interesting particulars respecting Mr. Hoy's collection, the following very singular passage occurs with reference to this species:- "On the 20th of May, 1827, a pair of the pratincole were shot near Yarmonth. A few of them breed annually in the fens near Yarmouth, in the same locatity as the ruffis, with which they are sometimes taken." Mr. Hoy's thorough acquaintance with our eastem coast and the entire "broad district," renders this passage the more inexplicable, but whatever bird, through some Tapsus calami, may have been here confounded with the pratincole, there can be no question that this rare species was at no timo a resident in our marshes, or otherwise, than it now is, a very rare and accidental visitant. 
wall, and the same birds, in Sir William Hooker's MS., are stated to have been male and female, and their stomachs filled with beetles. These specimens, as I am also informed by Mr. Joseph Clarke, of Saffron Walden (from whom Yarrell obtained his information respecting them), were shot, on the 21st of May, by a fisherman named Joln Bessey, who sold them to the late Isaac Harvey, a game dealer, at Yarmouth, for twenty shillings. They were extremely dirty and smeared with blood, and Harvey's wife washed them "as she would stockings," and hung them out on a pole to dry; but, in spite of this rough usage, they were subsequently re-sold by Harvey for $\{7$. Captain Longe, when residing at Yarmouth, took some pains to trace out this pair, but was unable to do so, nor have I been more fortunate through enquiries made in other quarters.** A specimen in $\mathrm{Mr}$. Gurney's collection, said to have been killed near Yarmouth, was purchased some years back at the sale of $\mathrm{Mr}$. Thurtell's birds, at Eiton, near Norwich; and of these, as I have recently ascertained from Mr. Hunt, a cashier in the Norwich Postoffice, the larger portion had belonged to his fither, whose name I have had frequent occasion to mention as an authority on questions of local ornithology. It is quite possible, therefore, that Mr. Gurney's bird may have been one of the original Yarmouth pair, which are also recorded by Hunt in his "List of Birds" published in Stacy's "History of Norfolk." The only other example, and also the last that $\mathrm{I}$ am aware of, as having been lilled in this comty, is the one recorded by Yarrell as shot in May, 1840, on the shore of Blakeney harbour, by Henry Orerton, a noted fowler.

* Bessey's son remembers their being killed, and thinks they may have been purchased either by the late Mr. Sparshall, of Norwich, or Sir R. Adair's father. 
This birl came into the possession of the late $\mathrm{Mr}$. James Sparham, of Blakeney, who presented it to Mr. Henry Rogers, then residing at Thetford. Some few years later, on Mr. Rogers leaving England, this pratincole passed into the hands of the late Mrs. Flower, of Feltwell, and is now in Mr. Nerveome's collection at Feltivell Hall.

\section{CHARADRIUS PLUVIALIS, Linnnus.}

\section{GOLDEN PLOVER.}

The Golden or "Whistling" Plover, as it is locally termel, is a regular autumnal visitant, but varies as much in numbers, according to the season, as in the time of its arrival. Pretty generally distributed thronghout the county, it is met with in flocks of more or less cxtent, throughout the winter months, except during periods of extremely severe weather, * when, like other kindred species, it passes southwards, for a time, to return again with the earliest change to a more genial temperature. $\dagger$ At such times, after the breaking up of

* Mr. Cordeanx, in his "Ornithological notes" from North Lincolnshire ("Zoologist.", 1867, p. 690), refers to the partial migrations of this species during sharp weather. In the first week of January, 1867, he says, during a sharp frost, " not one was left in those places where a few days previously they had congregated in thousands." On the $23 \mathrm{rd}$, however, a rapid thaw commenced; and on the 24th, when the marshes were once more clear of snow, "considerable flocks of golden plover had returned to their old haunts."

+ Mr. Lubbock gives a remarkable instance of the "weather wise" instinct of this species, so appropriately termed plavialis on that account. The extraordinary restlessness of sereral flocks of plover and lapwings in the marshes, so impressed him on ono 
a hard frost, and the re-appearance once more of verdure from under the deep snow, the whistle of the golden plover, as they rise from the fields, sounds cheerily in the bright sunshine of a winter's morning. The experience, however, of old sportsmen and others best capable of judging, indicates a very marked decrease, of late years, in the number of these birds as observed in this county, and even in a locality as little changed in its general features as Thetford warren, Mr. Bartlett informs me that they are seen only in scores instead of hundreds as formerly. About Feltwell, also, they are considered scarce.

Their southward movements, as is the case also with many of the Tringe, commences far earlier in the autum than is generally supposed, and, considering also their late stay with us, at times, in the spring, their nesting duties in more northern localities must be performed in a very limited period. It is by no means unusual to hear the well known notes of these birds, at night, by the middle of August, as the vanguard of their migratory forces passes over this county, and straggler's occasionally killed at such times leave no doubt as to the identity of the species. In Mr. Dowell's MS. notes, I find mention of a single golden plover, seen by him at Blakeney, on the 26th of July, 1853, the earliest date of which I have any record; but the same accurate observer noticed several small families in August, 1852, frequenting the "freshes" about Blikeney and Morston; some individuals still retaining their full summer plumage. Mr. Alfred Newton tells me that in 1852 he and his brother Edward saw a small "trip"

occasion, in the month of December, that he was thereby induced to put off an intended journey. On the next morning, which was calm and mild, the plover had all left; but, in the course of the night, so great was the fall of snow that the lanes were filled with the drift to the depth of six or seven feet.

ז 2 
of five on Thetford warren, on the 30th of July, and that between the 17th and 20th of August following, they observed several larger "trips," numbering" altogether from thirty to fifty birds, on the same locality. In 185\%, too, they saw a "trip" of abont five and twenty on the 1.th of August. Mr. Lubbock also states that two were shot on the 23rd of August, 1827, from a flock of seven on the edge of Horsey broad; and on the 18th of August, 1856,* I was shown a pair of, apparently, young birds which had been picked up that morning on the line near Yarmouth, having flown against the telegraph wires during the night-a not unfrequent occurrence. One of these had its head completely cut off; and the other was found ruming about between the rails, with one wing half severed from the body. It is not, however, mutil near the end of September, or more ustully in the following month, that such flocks as frequent our stubbles and fallows tempt the sportsman to leave the partridges for a time, and enleavour, by careful stalking, to obtain a shot. This, liowever, as the plover generally alight in the middle of a field, is extremely uncertain, but by walking round and round them, each time gradually narrowing the circle, they may sometimes be appronched near enough for a successful shot. Not unfrequently, also, by firing one barrel at random, a fair chance is offered for the second, as golden plover, as well as lapwings, invariably sweep downwards in a body, and then scatter in all directions after the first report. I have generally found them more abundant during November than in any other month, when, as Mr. Lubbock remarks, "they seem to divide their time between the marshes and

* A single bird, black-breasted, was flushed by Mr. Cordeaux, from a marsh, in North Lincolnshire, on the 3rd of August, 1867, as recorded in the "Zoologist" for that year, p. 946. 
uplands. If they are in a marsh all clay they often move off to a ploughed field just as it is dusk, and vice versa; if upon arable land, they go down to the marsh for the night." My own experience exactly confirms this statement, as some years since, when in the habit of shooting, late in the season, at Franingham, near Norwich, I used frequently, after leaving the turnips, to await the chance arrival of plover on the high grounds where they roosted, at times, in large "congregations." In the vicinity of the coast they are also found in great plenty during the winter months, both at the mouths of our tidal rivers, and on the flat shores of the "Wash," alternating between the "muds" and marshes, as the tide ebbs or flows. As before remarked, their numbers, like many other winter visitants, depend much on the severity of the season, a sudden change to frost and snow, bringing large accessions from more northern localities. In the extremely sharp winter of 1859-60, when our rivers were frozen over, a large quantity of both golden plover and lapwing were brought to the Norwich market, on the 23rd of December; and in the winter of 1829, as recorded by Messis. Paget, a dealer in Yarmouth received in one day, from the surrounding district, a hundred and fifty golden plover besides snipe and wildfowl.

The not unfrequent occurrence of specimens in the spring, late enough to have acquired the black breast of their summer plumage, has no doubt led to the supposition that they have occasionally remained to breed here, an impression evidently entertained by Messrs. Sheppard and Whitear, owing to a few being seen, on one occasion during the nesting season, on Mouseholdheath, near Norwich.* Of this, however, I can find no

* A locality also named by Hunt as an occasional resort of this species late in the spring. 
proof either in our own or earlier times, although straggler's may be seen in every month of the year, and Sir Thomas Biowne particularly remarks of this species, "they breed not with us, but in some parts of Scotland, and plentifully in Iceland." **

Mr. Lubbock states that a pair seen on Thorpe common, on the 26th of April, 1823, were in the nuptial plumage, and the female when shot was forward in egg'; a few also exhibited in our fishmarket for sale on the 5th of April, 1855, were all, more or less, in a state of change. On the 15th of May, 1856, a single bird, in full summer plumage, was brought in to one of our birdstuffers; and on the same day, as I find by my notes at the time, a couple of land-rails and a nest of nightingale's egors; but a still later date is given by Messis. Gurney and Fisher, who have known this species to be killed in Norfolk on the 25th of May. Such cases are, however, quite exceptional, but as regards those which may be said to have wintered in Norfolk, the northward movement takes place for the most part in April, whilst others from more southern quarters appear in May, with the knots and godwits, and, according to the prevalent winds at the time, are met with for longer or shorter periods by the Breydon gunners.

There is one point connected with the migratory movements of this species, which would seem, until very recently, to have escaped the notice of British ornithologists-it is their whistling by night over our cities and towns, when attracted by the glare of the lamps on their nocturnal passage. The very early autumnal migration of these birds is thus clearly indicated in some seasons, as well as fresh arrivals during

* In Wilkin's edition of Sir 'Thomas Browne's works, vol. iv., p. 319, the word "Iceland" occurs in this passage, but it is no doubt a misprint for Ireland. 
the winter months. Probably many of my readers have remarked, at such times, the melodious notes of these plover, which would seem to be uttered incessantly in order to keep the whole body together; and as this always occur's when the nights are extremely dark, I believe the birds, once drawn within the radius of the city lights, become perfectly bewildered, and fly round and round for hours, till, at day-break, the spell is broken, and they resume at once their direct course of flight; for, in no instance have I known, under such circumstances, any unusual number observed in the neighbourhood on the following morning. I have heard them myself on more than one occasion, when sitting up late, or from some cause unable to sleep, passing and repassing over the house-tops throughout the night, their plaintive cries now dying away in the distance, and now again so loud and clear over head that it has seemed as if a gun fired upwards at the sound must inevitably do some execution amongst them; since, though lost in the darkness, the noise of their wing's is at times quite perceptible.

The following are the dates on which occurrences of this lind have come under my own notice during the last sixteen or seventeen years, whether residing in Norwich or in the immediate neighbourhood; but it is worthy of note that here, in every instance, these birds have been heard either in autumn or winter, as I have no record of any similar event, at other periods of the year:-*

* That this does not, however, hold good, as a rule, is shown by the following note, communicated by Mr. J. Morgan, of Stratford-on-Avon, to the "Field" of March 31st, 1866, p. 273, which is alditionally interesting from the fact that varions species were actually picked up dead and examined on the following lay; thus proving the miscellaneous character of this particular flight, and by inference, also, of others, where many different notes have been 
1850. November 29th. From about nine o'clock in the evening large numbers heard over the city till nearly daylight; the night very dark.-December 1st. Again very numerous; night fine and dark.

1851. October 21st. A large flight over the city; very dark at the time.

1856. August 20th. Plover heard nearly all night; very dark. Incessant rain for twenty-four hours. Two lilled against telegraph wires the same week.

1857. October 13th. Large numbers over the city ; night dark, but fine.

1860. August 14th. A small flight heard over the city.

That the above dates, copied from my own notebooks for the last serenteen years, represent all the occasions on which these birds have been heard, at night, over the city, during that period, I do not pretend to say, but inasmuch as a dark night at the exact period of their migration, alone brings them under the influence of our city lamps, it is quite possible that one or more seasons may elapse without their presence being thus indicated by their clamorous cries.

heard at one time :- “On Thursday morning last (March 22nd), about half-past two, this town was visited by an immense flock of birds, of many species, but principally starlings, and their proceedings for some time created alarm. They swarmed on the chimney tops and on other parts of high buildings, while others were wheeling about and uttering cries as though they had been seized with a panic, dashing themselves against the walls, \&c., with such violence that scores were picked up next morning dead; while I should say at least a hundred or two were captured in houses, having fallen down the chimneys. **** I have seen many of the birds, starlings, snipe, ringed-dotterel, wild-duck, \&c., and I have been informed by others of wild-geese, partridges, thrushes, blackbirds, \&c., being in the flock. The night was dark, the stars being faintly visible, and it was impossible to tell from what direction they had come." 
Accustomed, however, as I have been for some years to listen for these well known sounds at the beginning of autumn, I never remember noticing any particular mingling of notes-although at times the golden plover and lapwings seemed massed together-until the 23rd of August, 1865, when the feathered host which then visited our city and neighbourhood* exceeded not only in numbers, but in combination of species, anything before recorded in this part of the kingdom. The night was extremely dark, and the close sultry air foretold the storm which, about two a.m., culminated in one terrific flash of lightning, accompanied by a deafening peal of thunder and a perfect deluge of rain. Between nine and ten o'clock I was first attracted by the ordinary whistle of the plover, but on stepping into the garden, became aware at once of the unusual character of this migratory flight. The air seemed literally filled with birds, but, though at times they were apparently within a few yards of one's head it was impossible to see anything, even when standing close to the gaslamps, on the road. Different flocks appeared to answer each other, and their confused clamour was so great

* I may here remark that a Correspondent in the "Field" (September 9th, 1865) records a large flight of birds at Leicester, as observed by himself on the very same evening. He was attracted by the noise, and on going out saw "the dark outline of a flock of birds, going in a south-westerly direction." From their notes ho believes the majority to have been "geese of some kind or other," and their attendants he thinks were of the plover species; but a friend imagined "that he could detect the note of an owl amongst the rest." In the following autumn, another Correspondent in tho same journal (September 15th, 1866), writing from Cranbrooke, describes a very large flight of birds as having passed over head on the 9 th of that month. It was raining hard at the time, and very dark. Their notes resembled "pweet, preet," appiurently uttered by some hundreds in each flock, and were heard by him, at intervals of about ten minutes, from half-past eleven till two a.m.

$\mathbf{L}$ 
as to attract attention from the least observant, and formed a general topic of conversation for days after. Although, judging from the sound, they appeared to come and go, there was nothing to indicate a direct movement in any particular direction, but rather, as observed on former occasions, a hovering round, their cries never altogether ceasing, though occasionally almost dying away in the distance. From subsequent enquiries I found they had been heard in all parts of the city, and for at least two or three miles round in every direction.* The main body evidently consisted of goldenplover, and with them were also lapwings and redshanks, in much smaller quantities. Occasionally the unmistakeable "crake" of a tern was heard, quite apart from the rest, and I believe I also recognised the scream of the black-headed gull; $\dagger$ whilst in the general Babel of

* A correspondent in the "Field" of September 2nd, 1865, writing from Norwich, mentions this same flight, on the 23rd of August, but seems not to have detected the variety of notes. He speaks of a large flock of golden plover being heard over the city from 9.30 to 1 a.m., of which, as he stood in a field listening to them, "thero appeared to be thousands," and by imitating their notes with a common dog-whistle he was at times "surrounded by them," and could hear their wings "buzzing through the air."

+ Lord Lilford, in his "Notes on the Ornithology of Spain" ("Ibis," 1865, p. 176), particularly refers to the "extraordinary cries of birds during the night," as observed by himself both in Eugland and on the Continent. "Once," he writes, "I listened for at least ten minutes to the continuous cry of a flock of birds, which cry I can only liken, and that very slightly, to the screech of the nightheron (Nycticorax griseus). Again, on the esplanade at Corfu, in tho summer of 1858, about $1 \mathrm{a.m}$. on a July morning, he was startled by "an uproar as if all the feathered inhabitants of the great Acherusian marsh had met in conflict over head." It was impossible to render any idea of the "Babel of sounds," most of which were quite unknown to him, although a practical ornithologist, but amongst them ho recognised "the wail of a curlew, the cry of more than one species of tern, and the laugh of some 
sounds came the murmuring of smaller migrants, such as thrushes and finches.* Many strange rumours were, of course, circulated at the time, but, with the exception of such species as I have here named, I could not ascertain that any others had been satisfactorily identified. Amongst them, owls were said to have been heard hooting by the road-side, and early in the evening large flocks of birds, like thrushes or redwings, to have been seen settling on trees and houses in the neighbourhood of the city; but none appear to have been shot. The extraordinary noise of the plover, induced most probably by the coming storm, was sufficient to awaken many people during the night, and thus afforded evidence of the presence of these birds for many hours, but it is

Larus." Mr. Alfred Newton also informs me that on more than one occasion during the last few years, in the month of August, ho has listened to similar flights orer Cambridge and its vicinity, and always on dark nights. From their notes he has supposed tho majority to consist of black-headed gulls, mixed with golden plover, and he has at times detected the cry of the long-billed curlew.

Mr. Cornewall Simeon, writing from Winchester, in the "Field," of December 8th, 1866, records a very remarkable gathering of birds, of various kinds, over that city on the evening of the 20 th, which were listened to by him from nine o'clock until twelve, when. he went to bed. The night was "dark, fine, and perfectly still," and by far the larger number appeared from their notes to bo fieldfares and redwings, accompanied by some dunlins and ringdotterel, occasionally a suipe or two were heard, and by the rattle of the wings at times, some larger birds, supposed to be wild fowl. It was impossible, he says, to form any estimate of their number, as they passed steadily over in those three hours, only a ferr occasionally "circling round as if dazzled by the lights of the town," but the air seemed literally full of them.

* The migration of various classes of birds, to our coast, in ono large body, as observed during the day, is specially referred to by Sir Thomas Browne, who says: "teal, woodcocks, fieldfares, thrushes, and small birds, come and alight together; for the most part some hawks and birds of prey attending them."

L 2 
difficult to imagine what became of them in the early morning, when the rain fell in torrents. The next day no trace whatever remained of our nocturnal visitants, which, with their marvellous instinct, seemed to have passed on, to a bird, to their winter quarters.

As a delicacy for the table, this species deservedly stands in high estimation, and in earlier times, from such records as remain to us, appears to have been as highly valued. In the L'Estrange "Household Book" for" 1520, we find the Vicar of Thornham's servant receiving various gratuities for the bringing of plover, as presents, and when purchased the prices may be gathered from the following items:- " $\mathrm{Pd}$. for a crane and $\mathrm{vj}$ plovs, xxd. ;" "vj plovs, xiiijd.;" "vj plovs, xijd.;" and "iij plovs, vjd.", At a Royal feast, also, at Kirtlinge,* Cambridgeshire, in September, 1577, we have xxviij plover purchased at $\mathrm{xxx}^{\mathrm{s} .}$; yet, strange as it may seem to the modern epicure, at the very same festivities, in honour of our "good Queen Bess," xviij gulls were provided at a cost of iiijli. $x^{\text {s. }}$; and this with lambs at five shillings and pigs at a shilling a piece.

\section{CHARADRIUS MORINELLUS, Linnæus.}

\section{DOTTEREL.}

Although by no means so numerous as in former days, the Dotterel, as a regular migrant, still visits us at the end of spring, and again a few months later,

* See Extracts from "The Booke of the Houschold Charges and other Paiments laid out by the L. North, and his comandement: beginning the first day of January, 1575, and the 18 yere of our most gratius Sorerain's (Queen Elizabeth's) raigne." Communicated to the Society of Antiquaries, in 1819, by William 
frequenting chiefly the warrens and fens of the western parts of the county. Tradition, however, tells us that the "trips" which now visit this county are not only smaller but their stay shorter than they were formerly, when netting dotterel was a source of considerable profit to the fowler; ${ }^{*}$ this species having: been always considered a great delicacy for the table. Now-a-days the incessant and more noisy persecution of gunners, scares even the "foolish" dotterel from our inhospitable soil, which, on the other hand, presents less and less attractions through inclosure and cultivation. Indeed from the latter cause, on the eastern side of the county, they have for many years been extremely scarce, appearing at uncertain intervals and in various localities, to be noted only as rarities, if by chance observed. The Messrs. Paget, in 1834, deseribe them as "rather rare" in the neighbourhood of Yarmouth, as they are now, a few appearing occasionally, in spring, as on May 19th, 1866, when a pair were shot on the beach $\dagger$ with other migrants; and again on their return in autumn about the end of September, at which time, $\mathrm{Mr}$. Frere tells me, he has known three specimens (a young bird and two old ones) obtained during the last four years, on the beach and denes, but has never heard of one on Breydon. Further to the north, about Blakeney and Morston, they are also seen at times, on their migratory course. On the 12th of May, 1852, Mr.

Stevenson, of Norwich, F.S.A., and published in the nineteenth volume of the "Archæologia," pp. 283, et seq. Also a reprint of the same paper in "The progresses and processions of Queen Elizabeth," by John Nichols, F.S.A., vol. ii., p. 236.

* For the old method of taking dotterel by night, with a net and lanthorn, see "The Wild-fowler," by H. C. Folkard.

f In May, 1867, a single bird was killed on the beach, near Lowestoft, Suffolk, which Mr. G. G. Fowler informs me is the only one he has known in that locality. 
Dowell met with a small flock of from ten to twelve near the roadway leading on to the beach, at Blakeney, and five were sent up to Norwich from that neighbourhood during the same week. On the 9th of May, 1857, a single bird, just assuming its full plumage, was shot at East Ruston; and on the 10th of May, 1859, three males and one female were killed at Halvergate. Again, on the 9th of May, 1863, one old bird and three young of the previous year, were sent up to Norwich from Blakeney. A considerable number, according to Messrs. Sheppard and Whitear, "were seen in May, 1816, in the parts westward of Burnham," near the coast, and Mr. Lubbock states that one or two have been killed so near Norwich as "the verge of Mousehold heath," and that on one occasion, many years ago, a flock of fifty appeared in the parish of Eccles, of which a sportsman, who went in pursuit of them, obtained fourteen.

In west Norfolk, however, the more open "brecks" and warrens, from all time, and, of late years, the reclaimed portions of the "fens" have presented, from their wild features, peculiar attractions for these passing migrants. "The morinellus or dotterel," writes Sir Thomas Browne, "about Thetford and the Champian, comes unto us in September and March, staying not long, and is an excellent dish."* And in the very same locality, at the present time, although less numerous than in former years, Mr. Bartlett informs me that "with a fine April and a warm May," a few "trips" are generally observed on his warren, sometimes

* In the Northumberland "Household Book" (Temp. Hen. viii.) dotterel were sold at one penny each, the same price as teal and woodcocks, whilst stints were only twopence per dozen: In the Lord North "Accounts," also, for the Royal banquets at Kirtlinge (Temp. Elizabeth), viij doos and iij dotterel were supplied at vli. viijs. According to Yarrell, they fetch from seren to eight shillings a couple in the London market. 
amounting to about a dozen birds, but rarely as many as twenty. In the same manner, on the great fields about Westacre, a few still rest for a time on their passage in spring-a small flock being seen by $\mathrm{Mr}$. Anthony Hamond, jun., during the first week in May, 1867; but their small numbers, and less regular appearance, is remarked both by sportsmen and naturalists in that neighbourhood. From Feltwell $\mathrm{Mr}$. Newcome gives a very similar account. He killed one out of a small "trip," in May, 1867, and others were killed on Wangford warren, in Suffoll, during the same season; but he is inclined to think that since the drainage and cultivation of the "fens" these birds, on their arrival in May, prefer the newly sown bean and rye-lands to the warrens and sheep-walks, but this only on their vernal migration, as all attraction ceases with the growing crops. They are particularly partial to bare grass where sheep are feeding, but even in the most exposed localities will squat so close as to pass unnoticed till almost trodden upon, relying for safety rather on concealment than flight. The shooting of dotterel during their spring passage is a most unsportsmanlike practice, and to its prevalence must be attributed, in a great measure, the growing scarcity of the species.* For the birds killed at that season having escaped all the various casualties to which they are liable during the

* Some forty years ago ("MIag. Nat. Hist.," vol. ix., p. 525), Mr. Salmon attributed the falling off in their numbers, "of late years," to this cause, but at the same time it must be remembered that as long since as 1833 and 1834, the late Mr. Heysham, of Carlisle, who took so much pains to establish the fact of their breeding in the neighbourhood of the lakes, understood that they wero yearly becoming more and more scarce about Keswick and its vicinity, owing to their destruction by anglers, their feathers being in much request for dressing artificial flies (Yarrell, 2nd ed., vol ii., p. 461.) 
winter are then paired, and in another month would be breeding. The destruction, then, in the spring passage of a single bird is equivalent to the destruction of a whole brood. The gunners, however, who obtain a shilling a piece for them, have no scruples on this score, and though in cold or wet weather the dotterel are wary enough, on a fine sunny day, as Mr. Alfred Newton informs me, nearly the whole "trip" may be secured at repeated shots.

In connection also, of late years, with their brief stay in this county, is the far later period at which they arrive in spring (presuming, of course, that our eartier records are correct), appearing now, almost invariably, during the second and third week of May,* when the chief bulk of our passing migrants-knots, godwits, greyplover, and many others-pay a hurried visit to our shores, and, impelled by natural instincts, push onwards as quickly as possible to their northern breeding grounds. Yet, in 1843, Mr. W. R. Fisher, in "A note on the times of arrival of the summer birds of passage at Yarmouth" ("Zoologist," p. 248), gives the 25th of March as the date of Charadrius morinellus; and in Messrs. Gurney and Fisher's "List," in 1846 ("Zoologist," p. 1319) it is described as appearing in March and September, which agrees exactly with Sir Thomas Browne's state-

* Mr. Cordeaur, writing of this species, in North Lincolnshire ("Zoologist," 1867, p. 808), records the occurrence of a single dotterel on the 15th of April, as the only one he has ever seen so early; remarking that these birds "invariably make their appearance in those year's, when they do visit this neighbourhood, during the first week in May." In a previous note, also, on the same species ("Zoologist," 1866, p. 294), he says, referring to their former abundance in the North Lincolnshire marshes, in May, "From some cause or other their numbers have gradually decreased, and, previous to this spring, four or five years have elapsed without my seeing even a single bird." 
ment, nearly two hundred years before.* It is possible, therefore, that when fur more plentiful than they are now, their visits were spread over a longer space of time; separate "trips" arriring and departing again at intervals from the end of March up to the middle of May. It is also somewhat remarkable that, during the last sixteen or seventeen years, I have never seen a single dotterel, in autumn, either in our poulterers' or birdstuffers' shops, but both $\mathrm{Mr}$. Newcome and $\mathrm{Mr}$. Alfred Newton assure me that a few still visit the warrens in August, though, perhaps staying only a day or two, they thus escape observationt-a fact the more probable as at that time of year the warrens are little frequented, and in parts overgrown with brakes, among which the birds seek shelter from the sun in very hot weather.

In the dotterel, as in the phalaropes, the females are said to be the brightest in plumage, a statement which I have never had the opportunity of testing for myself, but Mr. Newcome assures me he has found such to be the case, and Mr. Newton's testimony is to the same effect.

* Mr. Salmon, in 1836 ("Mag. Nat. Hist." vol. ix., pp. 520, 525), gires the date of their appearance in autumn, in the neighbourhood of Thetford, as "the end of August or beginning of September."

In Pennant's "British Zoology" (1761), dotterel are also said to make their appearance on Lincoln-heath and on the moors of Derbyshire "in small flocks of eight or ten, only in the latter part of Amil, and stay there all May and part of June," and to be taken. in the months of April and September, on the Wiltshire and Berkshire downs.

† M. Julian Deby, in his "Notes on the birds of Belgium" ("Zoologist," 1846, p. 1251), remarks that "the dotterel is not a summer resident in Belgium, and is only seen during the two first months of autumn. * * * I have never noticed this bird on its return in spring, which inclines me to believe that it must follow some other migratory route at this season to that it pursues in autumn." 
That in earlier times this species was not only sought for by the fowler in this county, but afforded sport even for Royalty in the old hawking days, is shown by some entries in a curious MS. diary* of Hans Jacob Wurmser v. Vendenheym, who accompanied Lewis Frederick Duke of Wurtemberg, in his diplomatic mission to England in 1610. The Duke, proceeding by Ware, Royston, Cambridge, and Newmarket, appears to have arrived at Thetford on the 7th of May, $†$ where King James the First was then staying for the enjoyment of hare hunt-

* This very interesting diary, written in old French, is presorved amongst the additional MSS. in the British Museum, in a curions little volume bound in soft parchment, and is thus entered in the catalogue:- "Wurmser H. J., Travels with Louis Count (P) of Wurtemberg-20,001." Under the head of "Memorabilia;" a translation of certain portions will also be found in a communication by Sir Frederick Madden to the "Illustrated News" for February 28th, 1857 (

+ The presence of this Monarch at Thetford at that particular date, as well as on many other occasions, is recorded in the "Progresses, processions, and magnificent festivities of King James the First," as published, in four volumes, by John Nichols, F.S.A., in 1828. From that author it appears that on March 4th, 1604, Rowland Whyte wrote from Bayuard Castle to the Earl of Shrewsbury, "The King is at Thetford, and is soe farre in love with the pleasures of that place as he means to have a howse there." Subsequently, in the "Abstract of his Majesties Rerenew," we find amongst the keepers of the King's houses, the name of Lady Barwick and her son as receiving a yearly stipend for keeping the King's house and garden at Thetford, and from $160 \mathrm{t}$ he seems to have paid repented visits to this his favourite sporting scat, until, in 1616, as stated by Martin in his "History of Thetford" (p. 57) (and quoted by Nichols, vol. iii, p. 166), " he received an affront from one of the farmers belonging to the town, who being offended at the liberty his Majesty took in riding over his corn, in the transport of his passion, threatened to bring an action against his Majesty. Since that time neither that King, nor any of his successors, have visited this town." The King's house is still known by that namo. 
ing and hawling, his fuvourite diversions; and on the following" day, "apres que son $\mathrm{E}$ [xcellence] eut disné avecq sa Mato le duc de Lenox qui l'estoit venu visiter deuant disné le menu a la chasse ou l'on courrut le lievre, fit voller ung espervier et prient des Doterelles, oiseau qui se laisse prendre par une estrange manieve ainsy que nous avons veu. Et qui se peult mieulx dire qu'escripre." To my friend Mr. J. E. Harting, of Kingsbury, I am greatly indebted for a verbatim copy of such portions of the original MS.* as relate to these pastimes, it being important to ascertain the name actually used by this writer, in order to identify satisfactorily the species referred to. He suggests also, and apparently with much reason, that "the writer must have enquired the name

* A great inaccuracy occurs in Sir Frederick Madden's translation, the sentence "They flew a sparrow-hawk and took some doterelles" (in the original "fit voller"- - caused to fly) being rendered, "they saw a hawk seize some doterels;" the real meaning being that "they took or seized some dotterels, while, as we may suppose, the sparrow-hawk was flying. The hawk being let loose would make the dotterel lie close so that they could be netted, or driven into a net; and that dotterel were driven into nets we have Willughby's eridence in his "Ornithology" (1678), p. 310. After mentioning the common belief of their extending a foot or a wing as the fowler did, he quotes the information of $\mathrm{MLr}$. Peter Dent as follows :"A gentleman of Norfolk, where this kind of sport [the catching of dotterels] is very common, told me [Mr. Dent] that to catch dotterels six or seven persons usually go in company. When they hare found the birds, they set their net in an advantageous place, and each of them holding a stone in either hand, get behind the birds, and striking their stones often one against another rouse them, which are naturally very sluggish; and so by degrees coup them, and drive them into the net. The birds being awakened do often stretch themselres, putting out a wing or a leg, and in imitation of them the men that drive them, thrust out an arm or a leg for fashion sake, to comply with an old custom. But he thought that this imitation did not conduce to the taking of them, for that they seemed not to mind or regard it." 
of the bird on the spot, and, instead of translating it, simply put down the English word* as it was given to him."

\section{CHARADRIUS HIATICULA, Linnæus.}

\section{RINGED PLOVER.}

The Ringed Plover, one of our most interesting indigenous species, may be said to possess, at least in Norfolk and Suffolk, two distinct phases of existence, being found, throughout the breeding season, not only on the coast but on the great sandy warrens in the interior, where its sprightly actions and melodious notes enliven those dreary wastes from about the middle of March up to the end of August, when young and old again retire to the sea-shore and the mouths of our ticlal rivers, till the time once more arrives for this strange inland migration. To Mr. Salmon's notes in 1836 ("Mag. Nat. Hist.," vol. ix., p. 522) on the habits of these birds in the neighbourhood of Thetford (as quoted by Yarrell and other authors), I am enabled to add the following particulars from the more recent observations of Mr. Alfred Newton in the same district_-"The ringed

* That the word dotterel is "peculiarly English," I have the authority of Mr. W. Aldis Wright, the librarian of 'Trinity College, Cambridge and editor of Shakespear, who, in a letter to Mr. Alfred Newton, gives as the earliest instances of its occurrence, Drayton's "Polyolbion," song xxv. 1., 345; and Bacon's "Natural History," cent. iii., 236. The former first published in 1622, the latter in 1627. As further evidence, also, of its English origin, he quotes the following passage, under the head of Lincolnshire, from "Camden's Britannia [Holland's trauslation, 1637; the same passage occuring, as well, in the Latin edition, 1607], "dotterels, so named of their dolish foolishnesse, which, being a kind of birds as it were of an apish kinde, ready to imitate what they see done, are caught by candle light according to fowler's gesture." 
plover, or' 'stonehatch' as it is locally termed, breeds from March to Jume on Thetford warren. Whether the same bird lays more than once in the season I cannot positively say, but I have little doubt that such is the case. It certainly is so if the first eggs are destroyed or taken away. The 7th of February is the earliest date on which the species was ever observed by my brother or myself in that neighbourhood, and the 1st September the latest. We have known the first egg to be laid on the 23rd of March, and have found several nests with eggs (one with a single fresh egg) on the 8th of Jume; this was in 1851. When the birds first arrive in the district they are generally seen on the fallows, or on land from which turnips have recently been fed off. After a few days they betake themselves to the warrens, and remain there for the summer, frequenting the most barren spots. The nests are somewhat deep holes, apparently formed by the birds themselves, and having at the bottom a considerable number of small stones, almost enough to fill half the hole, and neatly arranged. On this parement, whence they derive their ordinary appellation, the four eggs are laid, with their pointed ends invariably meeting in the centre of the nest.* 'The cock bird has a regular song, in which he indulges during flight at this season."

On this warren, where Mr. Newton tells me he has seen some two dozen nests in one day-not necessarily all occupied, or even recent, for owing to the peculiarly permanent materials forming their "domestic hearths," these last many months, perhaps even a couple of years-their numbers appear to have decreased but little of late years, its character being unchanged; but at

* The nests being in reality deep cups in which the eggs are placed with their small ends downwards, Sir Thomas Browne was not so far wrong in stating, on the authority of the "Eringo diggers," "that they were set upright like eggs in salt." 
Beachamwell the different aspect of the soil of late years, has banished for ever these once numerous visitants. In that neighbourhood, as I am informed by the Rev. $H$. Dugmore, the greater part of the warren, about ten or twelve years ago, was broken up, and the remainder laid down for sheep walks, since which time (with the exception of the first year after the alteration took place, when a few made their appearance), he has not seen a single ringed plover, where, twenty years ago, they might have been counted by hundreds. The stone-curlew and lapwing, are still met with, but in much smaller numbers"not one in twenty to what they used to be"-and since the warren was thus broken up, such migrants as the sea eagle, the rough-legged buzzard, and the peregrine, of frequent occurrence in former days, are now rarely seen. In like mamner Brandon warren has been done away with for some years, but Mr. Newcome observed a few pairs in May, 1867, both on Lakenheath and Wangford warrens, in Suffolk, and they are still found, I believe, (certainly up to 1863) on Elveden in small numbers. I may here also state that Mr. Anthony Hamond, jun., showed me recently two eggs of this plover, taken, about twenty years ago, from a nest in Water-lane, in the Westacre district, close to Walton common, one of the few wet commons still existing in Norfolk. As far as I could learn but one pair of birds were seen at the time, and the nest was situated near a run of water, from whence this gravelly lane derives its name; nor have any birds of the kind been since observed, in that very exceptional locality.

Sir Thomas Browne does not appear to have known this bird as an inland breeder, but under the name of "Ringlestones"* describes it "as common about

* Mr. Alfred Newton informs me that "Ringel" is at the present day a Norsk name for this bird. The term sea-dotterel, also, frequently but erroneously applied to this plover, is of 
Yarmouth sands, laying its eggs about Jume in the sand and shingle;" and, from his time until within the last forty or fifty years, it was no doubt plentifully distributed during the breeding season over our entire coast-line, either nesting on the sea-shore or in close vicinity to the sea, on the margins of our tidal streams. Of late years, however, on the coast, as on the warrens, their numbers have sensibly decreased, and from causes, which must, I fear, eventually lead to their extinction as shore breeders-the wholesale plundering of their nests, for edible purposes as well as for the cabinets of collectors, and the even less justifiable destruction of the birds themselves during the summer months. In the neighbourhood of Yarmonth, as at Horsey and Winterton, there are many localities where they bred freely in former times, but which are now entirely deserted; and unquestionably the increased population of our watering places, and for the most part the easy access to them by railroad from the large inland towns and cities, have all tended to destroy the retirement of such

somewhat ancient date, as we find it thus used in two instances in the Hunstanton "accounts"- "It. pd to ye fowler (xxiiij weke 1525) at Corbetts for iij duss and di of stynts, $\nabla$ spowes, iij whyte plovs, and ij redshanks, and ij sedotterells xvjd. Also, in the vjth weke, 1533, "Itm iiij sedotterells iijd." Sir Thomas Browne also uses this name in some of his letters, but there is little reason to doubt, from his own description of the bird, that the "Morinellus marinus or sea-dotterel," of which he sent a draft to Dr. Merritt on the 6th of February, 1668, (see Wilkin's edition of his works, vol. i., pp. 403 and 405), was in reality the turnstone (Strepsilas interpres). In Ray's edition of Willughloy's "Ornithology," we also find, apart from the notice of the " sea-lark (Charadrius sive hiaticula)" [Book iii., p. 311], a tolerably accurate description of "The Turnstone or Sea-Dottrel: Morinellus marinus, of Sir Thomas Brown," to which the editor, alluding to their appearance on the Norfolk coast, adds-"Our honoured friend, Sir Thomas Brown, of Norwich, sent us the picture of this bird by the title of the Sea-Dottrel." 
districts, and banish altogether those species for whom the former condition of things was an absolute necessity. At the present time, in the long range of coast between Yarmouth and Salthouse, I know of no regular nesting place of this plover, although a few scattered pairs may possibly be met with; but from their head station on Salthouse beach to the shores of the Wash, they are still found pretty numerously in summer, and more particularly about Blakeney and Holme-point, near Hunstanton.

At Salthouse, though sadly decreased in numbers of late years, they have bred from time immemorial in company with the lesser terns (Stema minuta) frequenting the rpper portion of that natural rampart of flints, * which here constitutes the beach, and the sandy margins of the broad backwater that divides it from the raised sea-banks and marshes beyond. This preference for the vicinity of brackish waters, immediately adjoining the coast, is observable also at Blakeney, where they nest on the "ineals" and shingle, between the sea on the one hand and the tidal channel on the other; and at Holme, where a wide basin between the sandhills (alternately filled or emptied by the action of the tides), has attractions for them at all seasons.

I have reason to believe that on the coast, as on the warrens, the ringed plover nest much earlier than is generally supposed. It is true I have never found their eggs, myself, earlier than the first or second week in May, but this is mainly attributable to the fact, that my seaside excursions have, from necessity, been postponed till about that date, but the Salthouse beachmen, in whose statements I have perfect confidence, assure me that in some seasons they have found ringed plover's eggs by the middle of March; the ordinary time of laying being

* See introduction to vol. I., p. xxxii. 
early in April. By the first week in March they begin to "take to" the beach, and in very mild seasons even as early as February. Owing in a great measure, however, to the egring system, fresh ones may be here found, in plenty, up to the middle of May; and I have seen young birds just hatched on the 30th of May, and eggs hard set upon on the 12th of June. At Blakeney Mr. Dowell notes their appearance, in their usual breeding places, by the end of March, and in the first week in April he has found many nests already for laying, though as yet without eggrs; but, from the frequent occurrence of empty nests, sometimes four or five immediately around one containing eggs, he believes these birds are accustomed to make many nest holes before selecting one to lay in. When staying at Hunstanton in 1863, I found several birds sitting, on the 16th of May, whilst others, from their actions, had evidently young ones; yet a female that I dissected on the 19th contained one shelled egg, just ready for exclusion (of a pale green colour, with the usual spots), and four yelks of a bright yellow, graduating in size, besides a considerable cluster of un-impregnated egg's. Judging, therefore, from the state of the ovaries, and the plumage of this specimen, I should say that it was then about to lay for the first time that season.

So great a difference in the date of nesting in different individuals of the same species-for the birds of the warren and the coast are identical-has led some authors* to question the accuracy of Mr. Salmon's statement that he had found their eggs by the 30th of March, but this apparent discrepancy may, I think,

* Mr. Harting, in his "Birds of Middlesex," shows evident doubts on this point, never having found their eggs either on the Sussex or Lancashire coast earlier than the beginning of May, and still later in Northumberland, from which he infers that the more northward the breeding ground the later the period of incubation. 
be explained by the fact that, with us the ringedplover is both resident and migratory. In autumn the birds of the warrens retire to the coast, and swell the numbers of those which have passed their summer by the sea. On Breydon, also, as Mr. F. Frere informs me, both young and old make their appearance by the end of August* or beginning of September (some young birds returning sooner than others), at which time their flocks consist undoubtedly of migrants from more northern localitiest as well as partial migrants from our own inland districts. A large proportion of these again pass on to the southward, though some still remain, throughout the autumn and winter, at times consorting with dunlins $\neq$

* Mr. Cordeaux, in his "Notes from North Lincolnshire" for 1867 ("Zoologist," s. s., p. 9.5), says "Hundreds of theso little fellows made their appearance in the first week of August. These flocks contained an unusual number of dunlins." A small family of six, as an advanced guard, had been also observed on the 27 th of July.

+ This species is included by Mr. Alfred Newton in his list of the "Birds of Spitsbergen" ("Ibis," 1865, p. 504), and on the authority of Dr. MIalmgren, he states "that Professors Torell and Nordenskjöld, found on one of the Seren Islands, in lat. $80^{\circ} 45^{\prime} \mathrm{N}$., a brood of ringed plovers, which had probably been bred on one of these, the most northern islets of the known world." Their plaintive whistle has been also distinguished, amongst others, in those large nocturnal flights before alluded to under the head of golden plover; and in one instance (see ante p. 72, note) the ringed plover is specially named as owe of the species picked up and identified.

‡ This habit, as shown by Thompson ("Birds of Ireland," vol. ii., p. 101) "is fatal to them; for when by themselves the flocks are so small as to be considered unworthy of the fowler's notice; but when in company with the other, which usually go in large bodies, and consequently are 'worth a charge of powder and shot,' both are slain together." Mr. J. H. Gurney, however, who has recently had many opportunities of observing this species on the coast of South Wales and Somersetshire, where, in October and November, they appear in large numbers-sometimes over one hundred in a flock- 
(Tringa variabilis), and even during the intense frost, which lasted for several days in January, 1862, I observed several ringed plover on Breydon, when the half starved dunlins were being slaughtered by hundreds.

About the middle of February, in mild seasons, but more ordinarily at the beginning of March, these birds again make their appearance on Breydon in large flocks, though at that time, as Mr. Frere states, they are always extremely shy; and it is just at this early period of the spring that their melodious whistle is once more heard on the warrens, and they are found "taking to" the beach by the Salthouse gunners. Oceasionally, also, their "overland route" is marked at that period by the appearance of stragglers on the banks of our rivers, firr from their usual haunts, as on the $23 \mathrm{rd}$ of March, 1862, when a single bird was shot in a meadow, at Heigham, near Norwich. Some weeks later, however, usually about the first or second week in May, a second flight make their appearance on Breydon, arriving at the same time with the knots, godwits, and grey plover, which are then hurrying northwards to their distant breeding grounds, and that a portion of these, never very numerous, should remain on our shores, attracted by the presence of their own kindred, is not only, I think, a plausible theory, but one which would account for the late period at which their eggrs may be met with, quite apart from any casualties or even second broods.

has remarked that in such quantities they keep entirely separate from the dunlins or any other species. He has also noticed that "ringed plover are often seen in localities where the beach is not sufficiently muddy to attract stints, and that when the tide is falling both the ringed plover and sanderlings begin to feed at an carlier period of the ebb than the stints, and remain nearer the shingle, generally not going down so close to the ebbing wares as the stints do." 
My own observation of the habits of this species lias been confined entirely to their seaside haunts, where their presence lends a charm to the most monotonous range of sand and shingle. Many an hour have I spent amongst them on the Hunstanton sand-hills, with no sense of loneliness, but, revelling in the enjoyment of liberty and leisure, have felt all the enthusiasm of Macgillivray when he writes, "There is the broad blue sea, on that hand the green pasture, under foot and around the pure sand, above the sunny sky. Frown not upon the cheerfulness of nature; shout aloud, run, leap, make the sand-lark thy playmate. Why mayest thou not be drunk with draughts of pure ether ?" Here their nests are placed not only on the beach itself, but on the margins of those little tidewashed plains between the sand-hills, where the storm waves in winter have broken through and, far above the ordinary high water-mark, have strewn the surface with the debris of shells and seaweeds. As on the warrens, a simple hollow in the sand forms the only nest, and, in such localities, as described by Hewitson, the eggrs are not unfrequently screened from view by the long marram and other grasses, that wave over them.

The grey tints of their plumage, as well as the colour of their eggs, resemble so nearly the shingle on the beach, that it is difficult for any but a practiced eye to detect either, and usually the clear whistle of this plover, as it rises close at hand, is the first intimation of its presence. If searching, however, for eggs in any known breeding place, the spot should be carefully marked from whence the bird first starts, when, after running rapidly for some distance, it either stops suddenly in an attitude of apparent indifference, or, rising on the wing, betakes itself to some further and generally higher ridge of shingle. What a model for our bird-stuffers it then presents, with its head drawn back between the shoulders, the feathers of the body well puffed out-a round com- 
pact little figure with repose in every feature. Again, as we approach, it is all life and action, the head thrown well forward, and the breast carried close to the ground. A little quick run precedes the spreading of its wings, and, with a rapid sweeping flight, perhaps whistling as it flies, it seeks some further station. Once more alighting, the wings are closed, a few quick steps exhaust the impetus of its flight, and the former attitude is re-assumed. In feeding, also, by the water's edge, or on a smooth tract of sand left bare by the tide, its quick nervous actions and particularly the rapid movements of the feet, are extremely interesting; with now a little rum and then a stop to pick up some tiny atom of food, reminding one somewhat of a thrush searching for worms on a grassplot after a heavy shower. The food of this species, at least on the coast, consists chiefly of minute hard shelled molusca, and small shrimps and sand-hoppers. I have also found in their stomachs numerous small white worms, about half an inch in length, mixed with a few gritty substances. It so happens that I have never witnessed any of the artful devices, described by Macgillivray as adopted by this plover, to decoy intruder's from the nest, but my own experience quite agrees with the statement of Mr. J. R. Garrett, as published by Thompson in his "Birds of Ireland" (vol. ii., p. 98), that the hen bird when sitting on her egg's does not make any cry as she runs off, but that once the young are latched both parents become very clamorous when disturbed. At such times their anxiety is evinced by an irregular pitching flight, and somewhat altered note, resembling the word "pen-y-et," pronounced as three syllables, with a strong emphasis on the first and last. Whilst on the warrens, the ringed-plover is known as the "stonehatch," on all parts of our coast it is termed the "stonerunner," and at Salthouse dogs are commonly 
employed by the beachmen to find their nests,* which they do by scent, standing at each until the man comes up to examine it. But here, probably, owing to the close system of egging, which has prevailed for so many years, I have never found the full complement of four eggs, and the beachmen inform me that they rarely find more than three. Some few fragments of shell or shingle may be seen in their nest-holes as in those on the warrens, but on the beach this singular custom would probably pass unnoticed, since the small surrounding pebbles may be so easily swept in by accident. The young, which run almost from their birtl, are quite as difficult to find as the eggs, squatting close on the least sign of danger amongst the larger pebbles, to which the colours of their nestling plumage so closely assimilate. Specimens of these little creatures, sent me from Salthouse in their downy state, have the back of the head, neck all round, and the under parts generally, pure white; the forehead and crown (the latter bordered by a conspicuous narrow black band, across the occiput) the back and wing coverts, mottled with shades of light and dark grey, tinged in places with yellowish brown. By the beginning of August, however, both old and young, scarcely a bird remaining, leave the Salthouse shingles, and seek the more prolific feeding grounds at the mouths of such tidal channels as Blakeney and Cley; or in little family groups may be found roving along the coast, and feeding amongst the weed-covered rocks, left bare at low water as at Sherringham and Cromer.

Many of my readers are probably aware that the

* According to Yarrell (2nd ed., vol. ii., p. 171), when visiting Hastings, in 1833, ho found the same system of using dogs for egg gathering was commonly adopted on the shores of Kent and Sussex. 
naturalists at Brighton, * and other parts of the south coast, have for some years distinguished a smaller race of ringed plovers, which make their appearance in May and again in August, and are said to differ also in note from the ordinary kind, which have egg's and even joung, at times, before the arrival of these later migrants. It is not, however, I believe generally known that this smaller race is occasionally killed on Breydon; and I believe for the most part in May, although a recently killed specimen was shown me on the 11th of March, 1867. Unfortunately I have had no opportunity of examining these birds in the flesh, and camnot say, therefore, if there is any difference in plumage between males and females, or give sufficiently accurate measurements for comparison with those of the

* Mr. G. D. Rowley, writing from Brighton ("Ibis," 1860, p. 101) mentions particularly the existence of two kinds of ringed plover, at Shoreham harbour, the smaller of which he evidently confounded at that time with the little ringed plover of authors (Charadrins minor), from which, however, it is clearly distinct. In the same journal for 1865 (p. 465), Mr. C. A. Wright, in his "Second appendix to a list of birds obtained in Malta aud Gozo," states that the ringed plover, procured by him at Malta (where they begin to appear in IIarch), agree "in every particular of size and colour," with the smaller race procured at Brighton. He is not aware if the larger one is ever found in Southern Europe, but tho true little ringed plover (C. minor), he includes amongst the regular risitants to Malta and Gozo ("Ibis," 1864, p. 141.) In a foot note, also, to Mrr. Wright's paper, as quoted abovo (p. 465), the editor of the "Ibis," suggests that the smaller race of ringedplover "probably bears the same relation to Egialites hiaticula that Tringa schinzi does to T. alpina, and is inclined to beliere that this bird is identical with the Churultius intermedius of Mrénétriés (Cat. Voy. au Caucase, p. 53), "which he found to be not rare on the river Lenkoranka, near the Caspian." He further adds that a specimen procured from Natal by Mr. J. H. Gurney agrees "in erery essential respect" with those of the small race from Brighton. and Shoreham. See also "Ibis," 1865, p. 432. 
larger race. I am desirous, however, to draw the special attention of Yarmouth ornithologists to this subject, that the habits of this smaller race may be closely observed; more particularly as to the date of its arrival in spring and autumn, and whether seen, at such times, in separate flocks or in company with the larger kind. I am not certain that the smaller race has ever been found breeding on the south const, but in this county I have looked for it in vain during the nesting season, and, as before stated, the birds of the warrens are identical with those which frequent the seashore. All the Norfolk examples, also, of this smaller ringed plover that I have yet seen in collections, have been killed at Yarmouth, including one in the Dennis collection at Bury St. Edmund's. Judging from specimens of each bird in my own and the museum collection, the larger bird differs rather in its general bulk, than in the comparative length of wings, feet, or legs. The smaller ringed plover, as far as one can tell from stuffed specimens, has not the large round head and broad forehead of the ordinary race; the dark markings on the head and breast, are more pure and sharply defined; the whole of the upper surface of the plumage is darker in tint; and the bird has altogether a brighter and more dapper appearance. The outer tail feathers, in all that I have seen, have a dusky spot or two on the inner web, which is always white in the larger birds; the character of the beak appears much the same in both races, having the base of the upper and lower mandible yellow, which colour is permanent after death, but although there is scarcely any difference in the size of the legs and feet, the claws in the smaller birds are remarkably fine and long as compared with those of the larger race.

Mr. Lubbock's note on the Little Ringed Plover (Charadrius minor, Meyer) to the effect that "two specimens of this bird in the Norwich museum, were believed 
by Mr. Denny, the curator, to have been killed in the county, but the fact was not noted down at the time," is far too vague to entitle it to a place in the Norfolk "list," since in no other instance is it known to have occurred on our eastern coast.* One only of those referred to by Mr. Lubbock, and that in a rather dilapıdated condition (British series, No. 194), is now in existence. As it is quite possible, however, that this smaller species has been overlooked, it may be as well to point out its chief peculiarities of plumage as described by Mr. Harting, from a specimen killed by himself at Kingsbury. The base of the under mandible only is tinged with yellow, which is lost altogether in preserved specimens, and, though the outer tail feather on each side has spots on the inner web, "the shaft of the first quill feather, only, in the wing is white; and the white spots which are always present on the webs of the wing-feathers in the common species, and which give the appearance of a white bar across the wing in flight, are in the little ringed-plover absent." Merely the tips of the wing-feathers are margined with dull white.

\section{CHARADRIUS CANTIANUS, Latham.}

\section{KENTISH PLOVER.}

The earliest record I can find of this species having been recognised on the Norfolk coast, is contained in a paper by the late Mr. Yarrell, in the "Zoologieal Journal" for 1827 (vol. iii., p. 86), "on the occurrence of

* In the sale catalogue of Mr. Stephen Miller's Yarmouth collection, Lot 62 is entered as "kentish plorer and little dotterel," lut from enquiries made of those best acquainted with this colleclection I hare no reason to suppose that this was other than the common ringed plover. 
some rare British Birds," in which he notices the recent occurrence of two immature specimens at Yarmouth, and describes the difference in their plumage as compared with examples, at the same age, of Charadrius hiaticula. Of our local authors, Hunt includes it for the first time in his list of "Norfolk Birds," published in Stacy's history of the county in 1829; and under the name of the "Alexandrine plover," states that " a beautiful one in the Norwich museum was killed at Yarmouth."* When once it had been pointed out as a rarity, however, and its distinctive features made known, the Breydon gunners seem to have had no difficulty in supplying specimens to collectors. In the notes kindly supplied me by $\mathrm{Mr}$. Joseph Clarke, of Saffron Walden, I find one recorded as shot at Yarmouth, on the 1st of May, 1831 (also noticed in Sir W. Hooker's MS.) ; and of two specimens in the Saffron Walden museum, from the same locality, one was procured on the 1st of January, 1834, the other on the 1st of February, 1836. Mr. Clarke also states that about the same time in 1834 Mr. Hoy received one from Yarmouth, but Mr. Hoy's collection, according to Dr. Bree ("Field," vol. xxx., p. 465), does not now contain a specimen of this bird. Mr. Eyton, in his "History of the Rarer British Birds," published in 1836, says (p. 100) that he possesses "two specimens of this bird, obtained near Yarmouth ;" and Mr. Gould informs me that when he first began to collect British birds, over thirty years ago, he was in the habit of receiving weekly a basket of sandpipers and plovers from the same locality, supplied by Harvey, a dealer at Yarmouth, who at that time used to purchase specimens

* In the British series of the Norwich museum are three examples of this plover, but none of them seem likely to have answered this description even when first mounted. 
from the various gunners both on the coast and broads; and amongst the different kinds sent up in May were "a good sprinkling of Kentish plovers." In Mr. Spalding's collection at Westleton, is a fine adult male, purchased by him at Yarmouth, some five and twenty years agro; and $\mathrm{Mr}$. Newcome, of Feltwell, possesses one from Yarmouth and another from Lowestoft, the neighbouring seaport on the Suffolk coast. In the "Zoologist" for 1843 (p. 181) Mr. W. R. Fisher makes the following remarks on a male of this species brought to him on the 17th of April:-_" It was killed on a small lump of stones and shingle, which is, I believe, the only spot on Breydon left uncovered, except by very high tides. I mention this circumstance as corroborative of the attachment which this bird is said to show to stony ground, in preference to sand or mud." In the same journal also for 1849 (p. 2499), Mr. Gurney has recorded the occurrence of one or two Kentish plover at Yarmouth during the month of June. Two adult birds from Yarmouth, in the Dennis collection, at Bury, were obtained, no doubt, within the last fifteen years; and in my own notes since 1850 I find the following entries :-

1852. First week in May, one on Breydon.

1855. May 8th, one on Burgh-flats, near Yarmouth.

1859. May 6th, one on Breydon.

1861. April 24th, one on Burgh-flats, in the collection of the Rev. C. J. Lucas.

A pair, also killed on Breydon the same spring, are in the possession of $\mathrm{Mr}$. Overend of Yarmouth.

September 1st, one at Sherringham.

1865. April, one shot on Yarmouth beach, in the collection of Mr. E. S. Preston, of Yarmouth.

1867. April, one at Lynn.

These, of course, represent a portion only of the specimens actually procured in Norfolk during that o 2 
period (although showing their usual time of appearance and the localities they mostly frequent), yet whilst so large a proportion have been killed in the neighbourhood of Yarmouth, where they are so keenly watched for, there is no reason, I think, to infer that they do not also visit other parts of the coast, where they are far less likely to be distinguished from the more common species.

Mr. Frere informs me that, although observed on Breydon only in small numbers, scarcely a year passes without one or more examples being obtained in that neighbourhood, either in spring or autumn. In the former season they seem to arrive by the end of April or beginning of May (as shown by the above list, most frequently in the latter month) in company with other migrants passing rapidly northward at that period. On their return passage they are again seen, occasionally, about the first week in September, and stragglers, at times, even in the winter months. The fact, however, of this species having been seen in June, as recorded by Mr. Gurney, is no proof that it has ever remained to breed in this county (although it is quite possible that it may have done so unobserved), its appearance, at such times, being most probably accidental, as is the case also with the sanderling, turnstone, and grey plover, of which individuals may be seen, at chance times, during every month of the year.

I have not had the opportunity of examining specimens of this bird in the flesh, but Mr. Gould describes the bill and legs as hard and black, whilst the same parts in the ringed plover are pulpy and yellow; and in all plumages the former may be recognised by the white of the breast extending upwards to the chin, without any interruption, which is not the case with the ringed plover, even in its immature state. 


\section{SQUATAROLA CINEREA (Flem.)}

\section{GREY PLOVER.}

Grey Plover, though as compared with the golden at no time very numerous, visit us regularly in autumn, and usually make their appearance on Breydon and other parts of the coast, about the first week in October. Mr. Dowell, however, states that in August, 1852, he observed several frequenting the "freshes" at Blakeney, which still retained their full summer plumage, and I have occasionally seen young birds in September as early as the 17th, which at that time exhibited, in their first plumage, a great resemblance to the golden plover, for which I have no doubt in this stage, they are frequently mistaken.* One of these, in my own collection, killed on the 22nd of September, 1853, has all those portions of the upper parts of the plumage, which are usually white in the adult bird, more or less tinged with straw colour, resembling in this respect an example figured by Audubon in his "Birds of America." The large size of the bill, the presence of the hind toe, and the long feathers under the wing being black instead of white, as in the golden plover, distinguish this species at any age.

A few are seen on Breydon throughout the winter, but, as Mr. Frere informs me, not often as many as twenty or thirty at a time. Mr. Dowell describes them as seen mostly in pairs, which, joined to their shyness, renders them "much less profitable to the fowler than the golden plover, and they are, moreover, a great

* Messrs. Sheppard and Whitear, who include this species in their "Catalogue" under the name of the "Swiss sandpiper," mention the "yellow spots" of autumnal specimens, but evidently under the impression that this plumage is assumed by the old birds at that season and not confined to the young of the year. 
plague to the gunners by putting up other birds." He also adds that, although rarely congregating amongst themselves,* "they delight to consort with dunlins, knots, or indeed any birds of that kind." The grey plover differs also from the golden, in being essentially a bird of the coast, stragglers only, and those very rarely, being seen inland, as, in October, 1847, when a single bird was shot between Swaffham and Hilborough, as recorded in Mr. Dowell's notes; and Mr. Newcome shot one at Feltwell some years back, the only one he has ever seen in that neighbourhood. About the first week in May these plover again make their appearance on their way northward, having at that time nearly completed their full summer dress, $\uparrow$ and in cold backward seasons, such as that of 1853 , many beautiful specimens are procured on Breydon, with the red knots and godwits, as late as the 20th or 24th of that month. On the 20th of May in that year I purchased one of the most perfect specimens in full nuptial plumage, I ever saw; the beautifully marbled appearance of the back and wing coverts contrasting with the pure black of the neck and breast, and the white continuing from the forehead downwards, so as to margin the black on the neck and breast on either side, as far as the point of the wing.

On the 1st of July, 1854, I was shown a bird of this species, which had been shot at Yarmouth only the day before; and in the first week of June, 1863, I met with

* Lord Lilford, in his " Notes on birds observed in the Ionian Islands, \&c." ("Ibis," 1860, p. 339), describes a singular habit in this species, which seems to have escaped hitherto the notice of ornithologists, that of "throwing somersaults in the air, in the same manner as the tumbler pigeon and roller."

† Mr. Fenwick Hele in the "Field" (vol. xxix., p. 389) states that on the 2nd of May, 1867, he received "fire perfect specimens of the grey plover in full dress," killed near Aldeburgh, Suffolk. 
one or two at Hunstanton, with dunlins and sanderlings and, about the same time, as Captain Longe informed me, others were observed on Breydon. Yet from these unusually late, but accidental occurrences, there is no reason to suppose that the grey plover ever remains to breed with us.

There is little doubt, I think, as suggested by $\mathrm{Mr}$. J. H. Gurney, that the "white plovs," which occur once in the "Household Accounts" of the L'Estrange's, of Hunstanton, with other shore birds such as redshanks, "stynts," and "sedotterel," were of this species in their winter plumage.

\section{VANELLUS CRISTATUS (Meyer.)}

\section{LAPWING.}

At the present day it is only through the "tales of a grandfather," or the traditionary lore of some octogenarian, that one can arrive at any conception of the former abundance of this species, whose numbers for the last half century, at least, have been gradually but surely decreasing. We must carry our minds back to a period, by no means remote, when heath, warren, and fen occupied in this county about the same proportion that cultivated land does now, when, as has been elsewhere stated "less than one hundred years ago, Norfolk did not produce enough wheat to feed its scanty population." When, even in the "Enclosed" district, wide tracts of heath extended for miles through the inland portions, and an even wilder country as at Edgefield, Kelling, Weybourn, and Salthouse, adjoining the coast, was divided only by the then undrained marshes from the sea-shore. When, on the east and west, the 
"Broad" and "Fen" districts, but little cultivated, were the fowler's paradise, and the "Breck" district with its heaths, warrens, and sheepwallks-then, as now, the great stronghold of the lapwing and stone-curlewpresented a vast champain country with scarce a fence, fir-slip, or plantation, over thousands of acres, ${ }^{*}$ divided only by "mere balks" to mark the rights of tenure. Comparing, then, the present with the past condition of this great agricultural county, we can scarcely wonder at the effect which drainage, enclosure, and high farming have had upon the harmless lapwing; nor has its persecution been confined only to the inroads of the plough, since the wholesale plunder of its eggs for edible purposes, must lead eventually, I fear, to its extinction as a resident amongst us. On this point, even as far back as 1836, Mr. Salmon remarks-when writing of the arrival of this species at Thetford, with other migrants in spring, "they are at present tolerably numerous, although, of late years, very much decreased in consequence of their eggs being so successfully gathered to a very late period during the breeding season by persons who are adepts in discovering their nests." In the neighbourhood of Holt, some thirty or forty years back, as $\mathrm{Mr}$. Edwards informs me, their eggs were taken in considerable quantities, including many also of the stone-curlew, though at that time, from the difficulty of transit, but a small proportion of them reached the inland markets, yet now, on the same ground, only a few scattered pairs can be found in a season. At Westacre in like manner, and particularly on East Walton common, the amount of eggs reputed to have been taken, in favourable seasons, is

* In the 3rd edition of "White's Gazetteer of Norfolk," it is sitated that "two hundred thousand acres of commons and sandy heaths have been enclosed during the last ninety years." 
something almost incredible, whilst from long habit the men accustomed to seek for these nests could tell in an instant by the actions of the birds not only the males from the females, but whether the eggs, in any nest, were fresh or sat upon, or the young hatched;* and however astonishing it may seem to the novice, so easily misled by the many allurements of the parents, these noted eggers would walk direct to each nest, with the greatest certainty, though some half-dozen pairs of old birds might be on the wing at one time.

In the "Broad" district, as stated by Mr. Lubbock, a single egger, residing at Potter Heigham, took in 1821, "a hundred and sixty dozen $\dagger$ in the adjacent marshes," and the Messrs. Paget, writing in 1834 of the abundance of this plover, in the marshes near Yarmouth, as at Oby, Thurne, and Acle, state that Isaac Harvey, the Yarmouth game-dealer, was then in the habit of sending "between six hundred and seven hundred eggs to the London and other markets every week during the

* The late Mr. Selby, who had opportunities of observing this species in Norfolk as well as in other counties, referring to the expertness of those accustomed to search for their nests, says that they generally judge of their situation "by the conduct of the female birds, who invariably upon being disturbed, run from the eggs, and then fly near to the ground for a short distance without uttering any alarm cry. The males on the contrary are very clamorous, and fly round the intruder, endeavouring by various instinctive arts to divert his attention." The Rev. G. Low, in his "Fauna Orcadensis," describing the nest of the lapwing as a mere hollow scraped in the ground, and subsequently lined with bits of straw and bents, remarks "that this is often observed as a token whether the eggs are fresh or not, for when the nest is quite finished the incubation is pretty well advanced."

+ Yarrell, on the authority of $\mathrm{Mr}$. Plomley, records the fact that, in the season of 1839, "two hundred dozens of plovers' eggs were sent from Romney marsh to Dover;" dogs being trained for the purpose of finding them. 
season." These, however, by no means consisted only of lapwing's eggs, as those of redshanks, reeves, snipes, and black terns were indiscriminately gathered, and too often, as Mr. Lubbock laments, without leaving a single egg in the nest to encourage the birds to keep on laying. In the Hockwold and Feltwell fens, as Mr. Alfred Newton informs me the eggs of "starns" (black terns, Sterna fissipes) were taken in former times to place in the lapwings' nests, and the latter would "lay to" them. The great demand, however, for plovers' eggs, even when formerly abundant, is best shown by the prices realised; ${ }^{*}$ and at threepence and fourpence a piece one can scarcely wonder at the over zeal of the gatherers. In 1845, Mr. Lubbock speaks of eightpence each being given for the earliest, and that the price then rarely fell below three shillings a dozen; yet in the present year, when scarcely a dozen or two were sent to the Norwich market, they could be purchased at four shillings. In their present scarcity, however, the eggs of the black-headed gull (Larus ridibundus) locally termed "peewits" (which no doubt aids the deception) are not unfrequently sold for the rarer lapwings'; and it is not a little difficult to convince those who have thus been gulled, that plovers' eggs, in a marketable sense, mean any kinds at all approaching them in size, shape, or colour. As ground-breeders also, the lapwings have other enemies than man; but the male bird exhibits great courage in defence of its nest, as graphically described by $\mathrm{Mr}$. Salmon in the following' passage from his Thetford notes:- "Stationed on a slight eminence in its vicinity, he no sooner espies

* According to Pennant in 1776 the London poulterers supplied these eggs at three shillings a dozen, and in 1812 Daniel, in his "Rural Sports," gives four shillings a dozen as the price, then, in the London markets. 
a rook, a hawk, or any bird, however large, approaching in the direction of the nest than he immediately makes up to it, and by a series of buffetings compels it to alter its course."

As to their present distribution, they may still be described as scattered pretty numerously throughout the breeding season over the entire "Fen" district, and are seen there in winter in considerable flocks, migrating constantly from one part to another, with every change of weather. On the great fields, also, in the neighbourhood of Swaffham, more particularly about Castleacre, Walton, and Westacre, they are plentiful as compared with other localities, but have decreased considerably during the past few years, and on the "Meals" and marshes bordering on the coast where they were once so abundant, a few pairs only are seen, here and there, where some little protection is afforded. In the summer of 1863 , in the long range of fresh water marshes between Holme and Hunstanton, I observed but two pairs during the whole of my visit, and both their nests had been by some means destroyed. Like the ringed plover the lapwings migrate to the inland warrens in spring, and breed on Thetford and Beachamwell, though from the testimony both of $\mathrm{Mr}$. Bartlett and Mr. Dugmore, they are now seen only in scores instead of hundreds as formerly. In about the same proportion also, at West Harling, they still nest on the "Breck" lands in that neighbourhood with the stone-curlew, as do also a few pairs on the high grounds at Thorpe and Mousehold, as well as in the low meadows at Bowthorpe, Cossey, and Colney, near Norwich; and on Flordon common, in the spring of 1868, some six or seven pairs remained to breed. In the "Broad" district the falling off in their numbers is very marked. Drainage and egging combined have here almost exterminated them in places, and throughout the great extent P 2 
of marshes between Norwich and Yarmouth, once so noted for our grallatorial residents, the lapwing has become almost as scarce as the redshank, and the ruff is no longer seen. The two former, however, still find congenial quarters in that wilder district bordering on the Bure, where, closely massed together, the Broads, large and small, have suffered but little change in their normal features. Here, too, at Hoveton, is shown what protection, aided by such natural advantages, may effect even now for the wilder denizens of the marsh, and whilst other localities are all but deserted, Mr. Blofeld is more than repaid for his watchful care, in listening to the mingled notes of his protegés, and observing their habits on his own estate.

At the close of the breeding season both young and old leave the warrens and high grounds, and are found in flocks in the low meadows (to which they are particularly partial when slightly flooded), and on all parts of the coast. Many are seen throughout the winter, though constantly shifting their ground, and in very severe frost they would seem to leave us for awhile; but are seldom absent for any length of time. That the number of our residents is largely increased in autumn and winter by migratory flocks from the north, we have the evidence of their unmistakeable cries, mingled with the whistle of the golden plover as they pass in masses over our cities by night (see ante p. 70); and on various dates in September, October, and November, Mr. Dowell has observed this species arriving in small flocks on the coast at Blakeney, at times, during heavy north and north-east winds "coming over" all day; and after recruiting their strength proceeding further inland. Their numbers at times also, late in the season, are far beyond the amount we might presume to be reared in these parts under the most favourable circumstances, and the Yarmouth gunners regard their abundance in winter 
as a good omen for sport, "no wypes* no fowl " being with them a common expression.

However monotonous, the wail of the peewit in its wild haunts has a charm for the ear of the lover of nature, and the sterile heath or wide level range of marshy ground is enlivened by its actions, whether watchfully listening with erected crest, or hovering and tumbling with its humming wings and strangely varied flight.

It is curious to find so accurate an observer as the late $\mathrm{Mr}$. St. Johnt describing the lapwing as "altogether a nocturnal bird as to feeding," since with us, at least, the contrary may be observed at all seasons, both inland and on the coast. At West Harling, some two or three years ago, in the early spring, I observed ten or twelve pairs in the middle of the day, all busily feeding on some recently ploughed land, and about the same time of year I once shot four out of a small flock on the cliffs, near Cromer, which, in like manner, were so deeply engaged that I crept up within range before they saw me. On moonlight nights, like the stone-curlew, they are on the wing, uttering their cries for hours, and I have also heard them in spring, with the "drumming" snipe, as late as ten or eleven o'clock, when too dark to distinguish anything. As pets for the aviary and garden, lapwings are both useful and ornamental, destroying large numbers of worms, grubs, and insects, and from their handsome plumage and pretty attitudes are very attractive. They are also particularly sociable birds, one captive not unfrequently attracting others of its

* As will be seen by the extracts from the Northumberland and other "Household Books," this is an old English term for the lapwing or peewit, and "wipa," is still its Swedish name at the present day.

† "Wild Sports of the Highlands," p. 135. 
kind. Of this, two curious instances occurred last year (1867), as Mr. Gurney informs me-one at Mr. Henry Birkbeck's at Stoke, and the other at Mr. Gurney Buxton's at Catton, some lapwings, netted in the Lincolnshire marshes having, in both places, been turned into a walled-in garden. At Stoke, one of the birds, not sufficiently pinioned, made its escape, but instead of deserting its companions returned with others of its own species; and at Catton other wild specimens joined the captives in the garden of their own accord. As a proof of the occasional longevity of this species, Mr. Barlow, of Bintree, records in the "Naturalist" for 1853 (p. 82), the death through accident of a peewit, which had been "fourteen years in captivity, in a walledin garden at Yarrow, the seat of Lady Townsend, in the parish of Bintry, Norfolk." The habit attributed by most authors to this species of attracting worms to the surface by jarring the ground with their feet, is altogether repudiated by Mudie, * who takes much pains to prove its impossibility, but the following anecdote, given by the late Bishop Stanley in his "Familiar History of Birds," seems strangely confirmatory of their sagacity in this respect. A young lapwing in confinement was supplied in addition to its common food, with a few square pieces of turf six or seven inches in thickness, on which were thrown a number of gardenworms, which buried themselves in the sods; care being taken to keep them moist by waterings. "The lapwing, when disposed for a meal, mounted one of these sods, and, standing on one leg, kept regularly beating the turf with the other."

Varieties are not often met with, but Mr. Salmon ("Mag. Nat. Hist.," 1836, p. 521), records the appearance during two successive seasons, of a white specimen

* "Feathered Tribes of the British Islands," 4th ed., vol. ii., p. 132. 
on Thetford warren; a female "having the usual marking's clearly depicted by light and dark shades."

The following notes on plover-netting, as still practised on the opposite shores of the Wash, have been most obligingly supplied me by $\mathrm{Mr}$. T. W. Foster, of the Wisbeach Museum, and from the novelty of the method described, and the gradual relinquishment of such arts and devices at the present day, cammot fail to be interesting to many of my readers:-

\section{Plover Netting in the Fens.}

The capture of birds by means of a net has long been practised by fowlers in the fens of Cambridgeshire, near Wisbeach, and has, in days gone by, been a very lucrative occupation. The birds so taken are principally waders, and include dunlins, knots, ruffs and reeves, redshanks, lapwings, golden plover, and occasionally curlews and black and bar-tailed godwits. On one occasion within the last twelve years a small flock of nine dusky sandpipers or spotted redshanks (Totanus fuscus) was so obtained, and I purchased them alive. The Zoological Society's Gardens have frequently been enriched by fen-birds which have been caught by nets in this locality. The nets are brought into requisition twice in the year, viz., at Michaelmas (September and October) and Lady-day (March and April) at which periods the birds visit the washes. I personally know one fowler who has taken as many as four dozen and nine lapwings at one time, and twenty-four dozen in the course of a single day. The market price of this species is sixpence each.* Guyhirn and Whittlesea washes were at one time

* Although, compared with the golden plover, not ranking very high as a delicacy for the table, the lapwing appears to hare been greatly esteemed in former times. In the "Account Book" of the Purser of the priory of Durham (1530 to 1534), we find " 3 plovers 
periodically flooded, and many varieties of wild fowl visited them. Since the improved drainage of those parts of the fens, it is seldom that the washes are naturally flooded, and the fowler's occupation would be gone were not artificial means adopted. This latter mode of flooding is by means of a "slacker" or small sluice, through which water is admitted, and an area of eight to twelve acres is thus covered with water from six to eight inches in depth. In one portion of this lake the fowler constructs a small island about thirty-six feet in length and from four to five feet in breadth. Upon this his net is spread, which is stained the colour of the ground, and its meshes proportioned to the size of the birds he is likely to take; some nets having meshes one and a-half inch, and others three inches in size. The fowler keeps some live "decoy" birds (lapwings or ruffs) and a dozen stuffed skins or "stales," and these are placed on the island, close outside the range of the net. The living birds being tethered, are made to flutter their wings, whilst the fowler with a whistle imitates the call of the birds on the Wash; they are thus tempted to alight on the island, and are ultimately captured. The net, covering the surface, is so arranged that the fowler, who sits at a distance of upwards of two hundred yards, by means of a string attached to pullies, throws over the net, and the birds are jerked into the water and covered by it. The fowler rapidly approaches, and either takes the birds alive, or at once breaks their necks and

et 1 wype, 5 d. ;" " 1 plover et 1 snype, $2 \frac{1}{2} \mathrm{~d}$., and in the Northumberland "Household Book" (1512), it is especially ordered that "wypes be hade for my lordes own mees, only, and to be at ja. a pece." Again in the "Household Book" of the Lord North (1577), viij doos and $\mathrm{x}$ pewytts are entered at $\nabla^{\mathrm{li}}$. xvijs. viijd. $^{\mathrm{d}}$ and in a list of market prices, quoted by Mr. Lubbock from "Wade's Chronological History of Great Britain," the cost of a peewit, in 1633, was tenpence, and a dozen tame pigeons only sixpence? 
draws them through the meshes. The following is the method of arranging the net:-When stretched on the ground, the net is fastened down with small pegs on the side nearest to the fowler. It is held out in its narrow width by two poles, four feet in length, having a groove at the end, through which a rope passes from pullies fixed parallel to the poles and some few feet from them, and from which is also carried at right angles, the long line held by the fowler. The two poles work in joints, and, at the fitting moment, the fowler pulls the line, then the net is suddenly cast over and falls towards the pullies, throwing the birds into the water, and covering them as before stated. Lapwings fly with the wind, ruffs and reeves against it, and as they are some times taken when on the wing, the net is arranged accordingly, being held out by poles ten feet in height.

\section{STREPSILAS INTERPRES, Illiger.}

\section{TURNSTONE.}

This cosmopolitan species visits us regularly, though not very numerously, in spring and autumn, and except during extremely severe weather some few may be met with throughout the winter, with stragglers, at times, in every month of the year. By the end of July or beginning of August small family groups make their appearance on Breydon and other parts of the coast, where they consort with sanderlings, dunlins, and ringed plover, and, considering the lateness of their stay with us in spring, their return in so short a time, with young, well able to accompany their parents, is a fact of special interest in studying the habits of these migratory tribes. At Blakeney, a favourable point of the coast for this species, where, from its habit of turning over sea-weeds 
and other marine substances in search of food, it is known by the appropriate name of "Tangle-picker," Mr. Dowell has observed small flocks of seven or eight in the harbour as early as the 20th and 29th of July; and on the 30th of July, 1852, he noticed several families in the "narrows" apparently just arrived, mingling with small parties of sanderlings and dunlins. By the middle of September he has known them arrive more thickly; and on one occasion, on the 2 nd of October, he saw a flock of about fifteen near the "freshes." On the 12th of August, 1865, a young bird of the year was killed on Cromer beach; on the 24th of October, 1867, Mr. J. E. Harting shot a solitary specimen on Breydon; and on the 13th of November of the same year, two females were killed at Blakeney, whilst my own and Mr. Dowell's notes supply instances of their appearance both at Blakeney and on the shores of the Wash in the months of January and February.* At Yarmouth Mr. Frere tells me they are rarely if ever seen in winter. Their spring migration takes place about the second week in May; and between the 12th and 20th of that month, according to the season, small flocks make their appearance on Breydon, as well as on the beach at Yarmouth and other suitable localities, and these, like the knots, godwits, and grey plover, that arrive at the same time, are for the most part in full nuptial plumage, resting only for a day or so, and then passing on expeditiously to their more northern breeding grounds. Mr. Hewitson discovered several nests of this species in Norway about the middle of June, which would seem from other authors to be its

* M. Julian Deby, in his "Notes on the Birds of Belgium" ("Zoologist," 1846, p, 1251), in describing this species as a regular spring and autumn migrant, remarks, "I do not believe that any remain stationary with us during winter, as they are said to do on the English coast." 
usual breeding time, and as there is no reason to suppose that it ever nests on our own coast, the few that are occasionally seen here throughout the summer months are no doubt either immature specimens, or such, as from some cause or other, are not destined to "increase and multiply."

In June, 1846, Mr. Dowell shot a pair at Blakeney, the only ones then remaining on that part of the coast; and on the 4th of June, 1851, a single specimen was killed at Yarmouth. When staying at Hunstanton in 1863, I first noticed this species on the 25th of May, but never more than three or four together, and unlike the sanderlings, which were tame and plentiful enough, the turnstones were so shy that I failed to procure any, though much wanting specimens in summer plumage. By the end of May these small parties had shifted their quarters though the sanderlings still remained; but on the 10th and again on the 13th of June, I observed a single turnstone feeding by itself at low water, but so wary that it was only through a good glass that I could watch its actions. The flat sandy beach on this portion of the coast, must be particularly attractive to this species, strewn as it is with shells and sea-weeds, and abounding in the small crustaceans, marine-insects, and worms that constitute the main portion of their food. Their actions when feeding have been so minutely and accurately described by Audubon, as quoted by Macgillivray, and by Mr. Gould in his recent work on the "Birds of Great Britain," that it is needless to describe them here at any length, but the stone-turning habit from whence its name is derived, is no mere fiction of authors, but a fact to be realised at any time by an examination of the ground where these birds have been feeding.

Never having handled a living or freshly killed specimen, I have had no opportunity of examining "the small Q 2 
fleshy sheath or fold of skin" at the base of the upper mandible, described by Mr. Gould, which shrivels up and is hardly perceptible after death; but may not this singular appendage, the object of which is uncertain, be intended as a shield to protect the feathers of the forehead against the sharp edges of the shells and other objects, turned over by the beaks of these birds in their search for food? The turnstone is rarely met with far inland,* even at the period of its migratory movements, but Mr. Lubbock states that it has been observed on a small island on Hickling broad; and, as I am informed by Mr. Newcome, of Feltwell, on the 4th of May, 1853, he procured one specimen, which appeared with other strange visitants in his neighbourhood, when, after the great flood in November, 1852, several thousand acres of the "Fen" district were inundated for more than six months.

CALIDRIS ARENARIA (Linnæus.)

\section{SANDERLING.}

That a species so abundant and so widely distributed as the Sanderling should only very recently have been traced to its breeding haunts, $\uparrow$ and that authentic specimens of its eggs should still remain desiderata in nearly all cabinets, is no less strange than true. At

* Mr. Harting, in his "Birds of Middlesex," states that on one occasion in August, he met with a single bird of this species, so fur inland as the Kingsbury reservoir.

$+\mathrm{Mr}$. Alfred Newton informs mo that the sanderling has been found breeding by one, at least, of the explorers employed by the Smithsonian Institution, although the particulars have not yet reached him. 
Yarmouth, Mr. Frere tells me they arrive like the turnstones by the end of August or begimning of September, but are then less numerous than in spring; and are not seen in that neighhourhood during the winter months, although, on the shores of the Wash, (possessing more attractions for this species), I have often known specimens killed, in their relicate grey plumage, in December and Jamury. On that portion of the coast, in September, 1863, more particularly in the vicinity of Hunstanton, Mr. Dowell fommd them frequenting the beach, in flocks of from one or two humdred to fire humdred together, thonsands of them, in fact, being there congregated like dunlins, on Breydon, during hard weather; and to make quite sure of the species, he killed several specimens at different times. Whether this was, or was not, an exceptional visitation as to numbers, ${ }^{*}$ I am not prepared to say, but I have never heard of any similar instance in this county; and at Blakeney $\mathrm{Mr}$. Dowell has seen them only in small companies of from five to twenty or thirty, or scattered singly along shore. In this locality he has also remarked that "they do not come far up the harbour, nor are they seen on the mudflats, or joined with the miscellaneons assemblage of waders one so often sees mixed together in winter." By the 20th of July, also, in 1851, he observed several of these birds in Blakeney harbour, which Inad even then assumed their winter dress. Stragglers are but rarely met with inland, but $\mathrm{Mr}$. F. Norgate tells me he once knew a sanderling killed on some ice at Sparham, near Norwich, probably driven out of its course by heary gales at the time. Single birds are

* It is stated by Meyer, in his "British Birds," that in Holland the flocks of sanderlings not unfrequently amount to "many hundred indirifhals." 
not unfrequently seen consorting with dunlins, but when in small or large flocks they invariably feed by themselves.

With the sanderling, as with the knots and godwits, it is only by comparing a large number of birds killed at different dates, and of which the sex in each instance has been accurately ascertained by dissection, that one can arrive at any satisfactory conclusion as to the clange of plumage from the winter to the summer dress, or the differences observable between males and females. It was with this view that I collected specimens at Hunstanton in 1863, whenever opportunity offered, between the 19th of May and the 8th of June, and an examination of this very beautiful series of skins, fourteen in number, presents many points of interest. From the late period of my visit, of course even the earliest birds procured had nearly completed their change of plumage, but it is remarkable that, in both sexes, one or two examples killed in the middle of May were as perfect and as rich in colour as any I obtained in June, a circumstance which I lave since observed, at the same season, in the bar-tailed godwits (Limosa rufa), and from which I infer that very old birds or those of extremely vigorous constitutions acquire their full summer dress sooner than other's. This is particularly noticeable in a male and female both shot on the 26 th of May, the male being by far the darkest bird in the collection, and the female showing quite as much red on the fore part of the throat and neck as in any of the males killed in June. Two other females shot on the same day, young birds most probably of the previous year, are in the prettiest state of change possible, the upper portions of their plumage mottled with red, white, and black, with here and there a feather still pure grey, and their throats sprinkled with dark spots on a white ground, with scarcely a tinge of red yet visible. Again, 
as if purposely to puzzle an ornithologist and confound all his theories, a female shot on the 2nd of June has scarcely any red margins to the feathers on the upper surface of the body, and the chin, throat, and neck are almost as little tinged with red as in those last described. The females as a rule are certainly less rich in colour than the males, there being more grey mixed with the red and black on the upper parts, even late in the season, and their throats, however ruddy, show a white ground; whilst in fine adult males the dark spots on the throat may be almost said to rest on a red ground, so evenly is that colour distributed; still I cannot agree with General Sabine when he says, in the appendix to Sir Edward Parry's first Arctic Voyage, that the chin, throat, and fore part of the neck in the female sanderling may be described " as white, with a very slight sprinkling of dark spots, and scarcely any appearance of red," as I have dissected one or two females with so much red on those parts that I was quite unable otherwise to determine the sex. The plumage of six specimens killed on the 8th of June (four males and two females), and one female shot on the 2nd, may be thus described in general terms :-In three of the males, the feathers of the upper portions of the plumage are pure red and black, in the fourth male red and black mixed with grey as in females.* Their throats all more or less ruddy, but none of them equal in depth of colouring to the old male shot on the 26th of May.

* I was much struck on one or two occasions with the wonderful similarity in colouring between the plumage of these birds and the shingle of the beach, which, consisting of minute fragments of flint and pebbles, mixed with the detits of shells, was as prettily varied with red, white, and black as the backs of the sanderlings; and it was by no means easy to detect a specimen, even when intentionally placed amongst the smaller stones. 
Of the two females lilled on the 8th, the upper parts show more black than red, varied with grey margins to many of the feathers. In one the throat is white, rovered with dusky spots, with hardly a trace of red appearing; whilst in the other the red is a little more distributed. The female of June and has the upper parts as in the other two, except that the tail coverts are still light grey, but the neck and throat are as red as in any females I have seen, thus showing loow strangely variable these birds are in the assumption of their breeding plumage. The females are slightly larger than the males, but even this is subject to exceptions, and cannot, therefore, be relied upon altogether as a sexual distinction; and the absence of the hind toe renders it impossible to confound this species with the dunlin or other small waders, in any stage of plumage.

Their stomachs I found extremely stout and muscular, and usually filled with the remains of small shrimps and sandhoppers, small white worms, little fragments of seaweed and minute beetles, mixed with a considerable amount of coarse sand. They were all in high condition, and, being covered with perfect layers of fat, required mnch care in skinning during the lot weather. I should here mention, also, that even in the females killed on the 8th of June, the ovaries contained no eggrs larger than a No. 4 shot, with a considerable cluster of smaller ones.

As its name implies, the sanderling is essentially a bird of the sea-shore, and I know no locality better suited to its habits and necessities than that where I first met with it, on our coast, between Holme and Hunstanton. On these flat shores an immense tract of sand is laid bare at low water, abounding in little pools and streamlets, and teeming with those minute forms of Mollusca, Crustacer, \&c., which form the chief foot of the smaller waders. Here, with the mussel-scalps 
on the one hand, and the submerged forest on the other, where huge trunks of trees lie buried in the darti peaty soil, or a stratum of soft blue clay crops out anidst the sand, a daily renewed banquet is afforded to every species of shore-bird. On these moist level sands, the sanderlings are distinguishable by the whiteness of their breasts, at a great distance, looking at first sight, when feeding towards one, like little lumps of white chalk dotted over the surfice, which, howerer, on a nearer approach become strangely animated, and the light and dark shades of the upper and under plumage alternately presented to the eye, have a beautiful effect on a bright sumny day. Although, as compared with dunlins and turnstones, I always found these birds extremely tame; yet from the very nature of the ground, it was almost impossible to obtain a shot at them on the open sands, as without showing any particular alarm, they would always manage, by running on and feeding in advance, to keep just out of range; but occasionally I surprised a solitary bird by the edge of the mussel-scalps, or when too busily engaged with the last bit of seaweed thrown up by the waves. At high water, however, in small flocks of from five or six to about double that number, they were much more accessible, and the raised banks of shingle, or the sandhills beyond, afforded means of approach. Their actions when feeding are exceedingly pretty, occasionally raising their wings over the back like golden plover, without attempting to fly, ruming and stopping with quick nervous steps, and apparently travelling with as much ease over the large shingle as over the smooth sands. When disturbed by the water's edge, they invariably flew out to sea, uttering their shrill but pleasing cry on the wing, and circling round would alight again on the beach some hundred yards further on. At such times, however, like the ringed plover, their most favourite 
place of resort was the margin of that tidal basin at Holme, to which I have before alluded, which, though at flood tide presenting a wide sheet of water, has a swampy marsh at one end, covered with coarse grasses, glasswort (Salicornia herbacea), locally called samphire, and other marine vegetation. Here, when scattered amongst the rank herbage, and not seen at times till they rose, I obtained most of my specimens, and by a lucky right and left on the 8th of June, the last day of my visit, secured the four males and two females, whose diversity of colouring I have already described.

Like many others of its class, should a sanderling happen to fall, "winged," into the water, it swims lightly and fearlessly, and, recovering itself in an instant, makes at once for the shore. In the sea, also, it rides buoyantly on the little billows, and with the most perfect coolness allows itself to be washed ashore, making off at an almost incredible pace as soon as it gains a footing. It is further noticeable, in all such cases, that although the bird may have fallen from some lheight into the water the wounded wing, only, is saturated with wet; yet that the rest of the plumage should be impervious to the water must surely, in these birds, be owing simply to muscular contraction.

\section{HEWATOPUS OSTRALEGUS, Linnæus.}

\section{OYSTER-CATCHER.}

The Oyster-catcher or Sea-pie as it is locally termed, once abundant enough in the breeding season on the northern shores of this comty, can now only be claimed as a resident through some ferw scattered pairs still lingering in one or two of the wildest and most retired of their former haunts. Mr. Dowell remarks that in 1848 
and 1849, "they were common at Blakeney all the year round"; and, until within the last seven or eight years, their eggrs used to be sent regularly every season to one of our Norwich bird-stuffer's from the same neighbourhood, with those of the common and lesser tern. In 1860, on more than one occasion, in June, I saw two or three pairs at Salthouse, not frequenting the beach but passing along the coast, apparently making for some point still further westward; and in that direction, about Warham and Morston, a few pairs still breed, as far as I can ascertain, in such quiet spots as are yet suited to their habits. At Hunstanton, on the 16th of May, 186:3, 1 counted over one hundred in a flock, at low water, busily feeding at the edge of the great mussel-scalp. From the flatness of the shore it was impossible to approach them within shot, wary as they always are when in large bodies, and the tide had already fillen so low that I question if even a Breydon punt could have been worked up within range for a big gum. Thus, fortumately for them, and I think equally so for myself, I was obliged to be content with watehing them through iny glass, and they certainly presented one of the most animated groups of feathered life I erer witnessed, from their varied attitudes, sharply contrasting colours, and loud ringing cries. They all disappreared when the tide rose, and from that time only a few were seen at different times till the 1th of June, when I again saw a flock of over sixty, but, like the former number, they were no doubt migrants, resting for a while on their passage northward, and were all gone on the following day. After that dite I never observed nore than one or two at any time, betreen Hunstanton and Holme, and from the cockle-gatherers, who are well acquainted with the habits of our shore birds, I learnt that the sea-pie had ceased to breed on the Holme shingles, but freculented the quict coast-line between Thornhim and Brancaster; 
where Mr. F. Norgate, who has made more recent enquiries on the spot, believes they are still resident.

By the end of August or beginning of September, they again make their appearance in the above-named localities in large flocks, which are increased considerably during the winter months. Some twenty years ago, at that season, Mr. Dowell found them at Blakeney in flocks of five humdred and upwards, but then remarkably shy; and the Rev. C. A. Jolms, in his "British Birds in their haunts," in stating that oyster-catcher's may be "reckoned by thousands" on the Norfolk coast in hard winters, particularly mentions the "eastern point" of Brancaster marsh, a place of perfect security from its openness on all sides, as one of their most favourite roosting places. "Towards this point (he writes) I have seen line after line winging their way, all about the same hour, just after sunset, all following the line of the coast, but taking care to keep well out at sea, and all advancing with perfect regularity, every individual in a company being at the same height above the water." At such times they are frequently taken in nets on the shores of the Wash, near Lymm, with many other birds, by a process which I shall have occasion to explain more at length in my account of the dunlin.

Although in 1825 described by the Messrs. Paget as "not uncommon on the beach" at Yarmouth, the oystercatcher can be reckoned only as a rarity on the eastern side of the county where the beach presents far less attractions for this species than the flat shores of the Wash, abounding in shell-fish, as various as abundant.

I quite agree with my friend Mr. Harting (" Birds of Middlesex") that the term oyster-catcher is a misnomer for this species, whose chief food appears to consist of mussels, whelks, limpets-struck off from the rocks with that wonderful blunt-pointed flat-sided beak, hammer and chisel in one-cockles, and other small 
molluses and crustaceans. With such a diet one would scarcely expect to find them any great delicacy for the table, but Mr. Dowell, who has eaten them, describes the flesh as "fairly good"; and in by-gone days, when sea-gulls formed part of the bill of fire, oyster-catchers would seem, also, to have been much esteemed. In the "Northumberland Household Book" we find the following order, "Item See-Pyes for my Lorde at Princypall Feestes and non other tyme;" but abundant as they must have been in former times on the Hunstanton beach, this species occurs but once in the "L'Estrange Accounts," viz., "The xxxviijth weke," 1525, "It. pd to Nicholas Grey for a sepye, a redshancke, and a stynte, ijd."

\section{CRUS CINEREA, Bechst.}

\section{CRANE.}

That the Crane formerly bred in England, the terms of an Act of Parliament, passed in 1533, and already quoted in the account of the bustard (p. 11) leaves no room for doubt, as the fine of twenty-pence was thereby imposed upon every person who should " withdraw, purloin, take, destroy, or convey," any egg of this species. But whether the crane ever bred in Norfolk must remain an open question. Turner, a fer years later, says ("Avium Historia, Coloniæ:" 1548), that "earum pipiones ipse sapissime vidi;" and as Turner, though a Northumbrian by birth, was educated and lived for nearly fifteen years at Cambridge, * it scems not unlikely that his personal acquaintance with the "pipers"

** Cooper's "Athenæ Cantabrigienses," vol. i., pp. 256-258. 
or young cranes was male in the fens of that county, with which we know the fens of Norfolk had so much in common that one cannot imagine a species like this to have constantly bred in the one without the other; and often as I have read that wonderful description by the late John Wolley of the breeding of the crane in Lapland ("Ibis," 1859, p. 191), in which he describes so graphically his nocturnal watch, the question has occurred again and again to my mind. His minute description of the general character of that Lapland marsh, the nature of the soil, and the surrounding trees and herbage, all so vividly remind me of the wilder portions of our "broad" scenery, as they still exist, that in former times with a far wider area, wholly unaffected by drainage, one can conceive no closer resemblance (excepting only in climate), to that "Isa Uoma" of the far North.

To return, however, from mere speculation to the few scattered fucts that remain to us respecting the history of this species in Norfolk, we find five entries in the "Household Book" of the L'Estranges', of Hunstanton, of cranes supplied to their larder between the years 1519 and 1533 , * the last being one of the few birds recorded in this list as "killed with the gun." Of these

* 1519. "The vth weke" [after the 25th of September; about October 30th.] "Itm pd for a crane and vi plovs $\mathrm{xx}$., and $\mathrm{ij}$ conyes iiijd. - - ijs. -

"The ixth weke" [about November 27th.] "Itm a goos, a pygge, a crane, iiij conyes, and a loyn of veile of gyste (articles received in lieu of rent.)"

1526. "The xxxixth weke" [after the 25th of March, about December 23rd]. "Itm iiij malards and a crane kylled wt the crosbowe."

1533. "The xxvjth weke" [after the xxixth day of March, about September 26th]. "Thursdaye, Itm a crane, vjd."

1533. "The xxxviij weke" [after 29th of March, about December" 19th.] "Tewysdaye, Itm a cranne kyllyd wt the gun." 
as given in the subjoined note (reckoning the number of weeks, from the last quarter-clay, on which each separate account commences), two appear to have been lilled in antumn, one in spring, and one in winter; the three first occurring about the usual migratory periods. Sir Thomas Browne (circa 1667), evidently regarded this species as a migrant only, in his time, as, in his "Account of Birds found in Norfolk," he says "Cranes are often seen here in hard winters,* especially about the champian and fieldy part," but adds, "it seems they have been more plentiful; for, in a bill of fare, when the Mayor entertained the Duke of Norfolk, I met with cranes in a dish." $\dagger$ But for this very decided statement of so accurate an observer, the following extract from the diary of the "accomplished" Evelyn, who first made the acquaintance of Sir Thomas at Norwich, in October, 1671, might lead one to infer that the Knight's

* Willughby (1676), writing of the crane in his "Ornithology," remarks, "They come often to us in England; and in the fen countries in Lincolnshire and Cambridgeshire there are great flocks of them, but whether or no they breed in England (as Aldrovandus writes he was told by a certain Englishman [most probably Turner], who said he had often seen their young ones), I cannot cortainly determine, either of my own knowledge or from the relation of any credible person."

† In the Northumberland "Household Book" (1512), we find the following entry:- "Item it is thought that cranys muste be liadde at Crystyumas and other principall Feestes for my Lordes owne Mees, so they be boght at $\mathrm{x} \nabla \mathrm{j}$. a pece." In the Lord North "Accounts" (1577) one crane is charged as much as "xiijs. iiijd.," with herons at about 3s. each. But that this great bird was classed amongst the chief delicacies, in former times, is shown by the following stanza from Barclay's "Egloges," A.D. 1570 :-

"The crane, the fesant, the pecocke, and curlerve, The partriche, plover, bittorn, and heronsewe, Seasoned so well in licour redolent, That the hall is full of pleasent smell and scent." 
cabinet contained eggs of the crane, stork, and other rarities all obtained in this county. After describing the house and garden as "a paradise and cabinet of rarities," consisting of "medails, books, plants, and natural things," Evelyn further adds, "amongst other curiosities Sir Thomas had a collection of ye eggrs of all the foule and birds he could procure, that country (especially the promontary of Norfolck) being frequented, as he said, by severall kinds, which seldome or never go farther into the land, as cranes, storkes, eagles, and a variety of water foule."

At the present day the crane can be reckoned only as a rare and accidental visitant to this county, appearing singly, instead of in flocks, and at meertain intervals; for the most part either in spring or autumn, on its migratory course, or by chance, as in olden times, during hard winters. Of such specimens as are still preserved in local collections, or of which any records exist, as far as I am aware, the earliest in point of date is a very light coloured bird in the possession of $\mathrm{Mr}$. Newcome of Feltwell, in which neighbourhood it was lilled in August, 1836. This bird, as Mr. Alfred Newton was informed some few years since by a man who had seen it at large on several occasions, frequented the "fen" in the harvest time, and used to keep during the day in the standing barley, on which it fed, but in the morning and evening it went down to the water. It was at that time mistaken for a stork, and a reward having been offered, it was shot by a shoemaker named Hudson, who laid wait for it as it walked out of the barley. The sex does not seem to have been noticed at the time, but it was stuffed by Reynolds, of Thetford, for the late Mrs. Flower, of Feltwell, at whose death it passed into the hands of its present owner.

A female (ascertained by dissection), in Mr. Gurney's collection, was shot by a labourer at Kirtley, near 
Lowestoft, Suffolk, in April, 1845, when, according to Messr's. Gurney and Fisher, it was observed "walking slowly in a barley field, apparently intent on searching for food, and was killed without difficulty. The wind had for some time previously been easterly." This specimen was for some years in the possession of $\mathrm{Mr}$. Abraham Scales, of Pakefield, who afterwards presented it to $\mathrm{Mr}$. Gurney.

Next in point of date is, I believe, an immature specimen in the collection of the Rev. H. T. Frere, of Burston, who has kindly supplied me with the following particulars:-It was killed in February, 1850, at Martham, near Yarmouth, by a young farmer, who, at first, taking it for a heron, attempted to stuff it, and thus, in a very bad state, it was brought shortly afterwards to the late John Sayer, of Norwich, bird-stuffer, of whom it was purchased by Mr. Frere. There was no question at the time as to the bird having been recently killed, and the plumage is that of the first year, with a few light coloured feathers showing through the dark ground.

Since that date, I am not aware that any example of this bird has been procured in Norfolk, but Mr. H. M. Upcher informs me that some few years back, he believes in the spring of 1865, he was driving with his father, when, in a meadow close to the road at Warham, they observed a crane, so tame that they at first supposed it had escaped from confinement. It rose when they stopped to watch it, and alighted again near a run of water in the same meadow, but on their return soon after it had disappeared. Subsequently he heard of one having been seen in the Sandringham marshes, most probably the same bird, which seems happily to have escaped destruction. It is particularly noticeable that, with the exception of the Feltwell bird, all three specimens have been observed in the close vicinity of the 
coast, and from their large size were, no doubt, remarked almost as soon as they had effected a landing on our shores.

\section{ARDEA CINEREA, Linnæus.}

\section{COMMON HERON.}

Whether certain members of the feathered race are possessed of so nice a sense of honour as to prefer being petted and preserved for a time, only to suffer death at the hands of legitimate sportsmen; or would rather forego such distinguished patronage and take their chance of existence with less noble forms, is just one of those points which, for want of any means of lingual communication, must for ever remain an open question. So far as concerns the Heron, once the noblest "quarry" of the Falconer, and the greatest delicacy at all " principall feestes," I cannot but think, though no longer protected by the pains and penalties of the law, ${ }^{*}$ that it is a gainer rather than not by the great changes effected in the sports and pastimes of the age. The "hawk and the harnsey" $\dagger$ have alike fallen

* According to Folkard "The statute 19 Hen. VII., cap. 11, prohibited the taking of herons in this country, except by hawking or with the long-bow, upon pain of forfeiture of $6 \mathrm{~s}$. $8 \mathrm{~d}$. for every bird taken contrary to that statute. It also restrained the taking of young herons out of their nests, on land belonging to other persons (except with the license of the owner of such land) under a penalty of $10 \mathrm{~s}$. for every bird so taken." All the statutes, however, affecting these birds, their young, and eggs are repealed under the Game Act of George IV.

+ Harnsey, heronsewe, hornseu, and hernshaw, are amongst the various terms formerly applied to this species. In a note to Dr. Cunningham's paper on "the solan goose or gannet" ("Ibis," 1866 , p. 13), the editor remarks, "'hanser' or 'hernser,' (with the still further corruption, as in the old proverb of 'handsaw') is 
from their ligh estate, but whilst the former, unhappily, meets no quarter at the hands of the gamekeeper, and ranks with the crow in the list of feathered vermin, the heron still retains a something of its former prestige, which, in the breeding season, at least, ensures it protection, a heronry, at the present day, being still regarded by most persons as a coveted possession.

Of this species Sir Thomas Browne* says, "the great number of rivers, rivulets, and plashes of water makes herns and herneries to abound in these parts; young herns being esteemed a festival dish, and much desired by some palates;" but at that time, and indeed until within the last forty or fifty years, herons did not build exclusively in lofty trees, seeking the vicinity of man's drellings, and gathering together in colonies like the rooks, but were scattered, in pairs, over the Fens and Broads, where their nests were placed sometimes on a lofty alder in a carr, sometimes on the dwarf sallow and alder bushes in the marsh, or were hidden like those of the bittern amongst the reeds and sedges. In many such localities the nature of the soil must in itself have afforded sufficient protection-the swamp presenting an impenetrable barrier against all human depredators;

now a-days in many places the common name for Ardea cinerea, and seems as if it could be hardly anything else than the Sanskrit 'hansa.' If so 'heronshaw,' abbreviated to 'heron' and 'hern,' is naturally from the same root." Again in Taylor's MS. appendix to Forby the derivation of heronsewe is given as from "the $\mathrm{O}$. E. sewe a dish (whence sewer, one who serves up the dinner), hence heronsewe may be a heron fit for eating, young and tender."

"I wot not tellen of his strange sewes,

Ne hir swans, ne hir heronsewes."- Снаucer.

* Writing of the spoonbill breeding in Norfolk, Sir Thomas Browne states "that they formerly built in the Hernery at Claxton and Reedham, now at Trimley, in Suffolk;" but, as far I can ascertain, no heronry now exists in any of those localities, and, with the exception of the latter, they have probably been abandoned for many years. 
but, of late years, the reclamation effected by artificial drainage would account, independently of our numerous gunners, for the abandonment by the herons of their older haunts. Mr. Lubbock refers to these marshbreeders, and I have conversed with many residents in the "Broad" district, who remember their nesting at Ranworth, Horsey, Irstead, and other places; and even the Didlington heronry is said to have been established, some sixty years ago, by a considerable colony, ${ }^{*}$ which formerly had their nests on low sallow-bushes, or amongst the sedges on the borders of the Feltwell and Hockwold fens.

Through the kindness of several correspondents, and especially of Mr. Thomas Southwell, I have lately ascertained the existence of several small heronries in different parts of the county, which were unknown to me when writing the introduction to my first volume (p. Ixiii.) Most of these are, however, offshoots from the older and better known colonies, and, from the changeable habits of this species, may in a few years be again abandoned.

First in importance, of course, both from its extent and association with the history of falconry in this county, is the Didlington heronry before mentioned. Near this colony, at High Ash, the late Lord Berners (when Colonel Wilson) kept heron-hawks for many years, and special reference is made to this fact by the authors of "Falconry in the British Isles." These hawks, as stated in my notice of the peregrine, were subsequently supported by subscription, but were finally given up in 1836; and though $\mathrm{Mr}$. Newcome, of

* Mr. Alfred Newton was thus informed in 1853, by William Spencer, of Feltwell, who had been thoroughly well acquainted from his boyhood with the birds of the "Fen." He was unable to say when the herons ceased to breed there, but " it was before his time," his age being then fifty-three. 
Feltrell, has since maintained a private establishment, and with his two remarkable falcons "De Ruyter" and "Sultan" had many grand flights in the Hockwold country, the Didlington herons, still strictly preserved, have suffered little persecution of late from this cause. Crows, rooks, and jackdaws, as egg stealers and even devourers at times of the young "squabs," may certainly be reckoned amongst their natural enemies; but of late years the extensive drainage of the "Fen" district, thus limiting their means of procuring food has had far more effect on the numbers of the Didlington herons than could possibly have been effected by the Corvida generally, which, in like mamner, are less numerous than in former times. A very elever sketch by Mr. Carter, taken from the summit of a Scotch fir, overlooking a portion of this extensive heronry, appeared in a recent number of the "Illustrated News,"* and the bird's-eye view thus obtained by the artist of that busy scene is described as most interesting. "On emerging from the deep shade, through the thick matted foliage of the Scotch fir tops, the old herons, alarmed by his intrusion, sailed to and fro anxiously overhead, while the young birds, which had been making a hissing and chattering noise, not unlike that of magpies, suddenly collapsed into silence, and peered cautiously from their nests." Deserted nests were tenanted by other lodgers, such as wood-pigeons, jackdaws, sparrows, and starlings; in one nest was a family of brown owls; and spotted and green woodpeckers, a wryneck, and a squirrel were also observed amongst the topmost branches. Some ten years ago, as I am informed by $\mathrm{Mr}$. Tyssen Amhurst, the present owner of the estate, owing to the old brushwood in the heronry (the trees of which were very tall ash) being cut down, the herons shifted their nests,

* See volume lii., p. 560, with description at p. 566. 
and began to breed about half a mile further off in this large Scotch fir-wood, where they are far more picturesque, and a great portion of the old heronry having been since demolished the park has thereby been greatly improved. At the present time, this still thriving colony boasts of some sixty or sixty-five nests.

The following particulars respecting the past history of the Earlham heronry, near Norwich,-which, with its branch establishments at Costessey and Taverham, ranks next in importance, have been kindly supplied me by Mr. J. H. Gurney, "About the year 1810, an oak wood, near Acle,* long tenanted by a colony of herons, was cut down, and the birds thus deprived of their old haunt, migrated to a rookery, at Keswick, near Norwich; but here, owing either to the persecution of the rooks or to the underwood being burnt on one occasion, they did not remain later than about the year, 1830, some of them having probably left before that date. They now attempted to establish themselves at Taverham, but were driven away by the gamekeepers; and, though a few remained about Taverham and Costessey, the main body removed to a Scotch fir-grove (since cut down), at Newfound, from which, after one season, they crossed the river to the Scotch fir-grove at Earlham." Here they again came into collision with the rooks, but as the young plantation by the pond grew up they removed thither from the Scotch fir-grove, and Earlham, until the memorable gale which occurred on the 28th of February, 1860, remained their chief stronghold; their numbers amounting, I am told, in some seasons to between eighty and a hundred pairs. The effects of this gale, happening at so critical a period when the old

* Hunt, in his "British Ornithology," mentions this Acle heroury and the fights which occurred for possession between the rooks and herons. 
birds had but just returned, and were busily employed in repairing and building their nests, proved very disastrous, many, even that season, forsaking this haunt for either Costessey or Taverham. On the 24th of April of the same year, I visited the heronry, and found the wind had made sad havoc with the fine Scotch firs, which laid strewn in all directions, several with nests still in their branches, whilst the remains of many others crackled under foot at every step. There were more nests standing, however, than I at all expected to find; and as the anxious parents soared high over head, waiting my departure, I was glad to see a goodly array of open bills and grizzly necks appearing in many cases above the platform of twigs. Yet from that time, partly owing, perhaps, to the loss of many favourite trees, and still more, I suspect, to the fact that men were employed throughout that breeding season in clearing out the fallen timber from the heronry, their numbers, year by year, gradually decreased, till, in 1866, not more than two or three pairs returned to breed at Earlham; and this, from no interference on the part of the rooks, which, from other causes, had also diminished in number.

At Costessey, as I am informed by the Rev. J. W. Evans, though at first disturbed by the keepers, they are now strictly preserved by the noble owner of the estate; and in 1866 about sixty nests were built in some spruce and birch trees at some little distance from the hall. Since that spring, however, many pairs have again returned to Earlham; and this year (1868) $\mathrm{Mr}$. John Gurney informs me some sixteen or seventeen nests in their old quarters afford every hope that the Earlham heronry will be once more re-established. A further offshoot, also, from this heronry has been long established at Kimberley, where $\mathrm{Mr}$. Lambert, the head gamekeeper, assures me he has known herons build on 
ash, elm, and other trees for the last twenty years. During the last spring (1868) there were only two nests.

Another, and probably one of our oldest heronries, is that noticed by Mr. Southwell in "The Naturalist" for April, 1853 (p. 87), as situated in Wolferton wood,* about six miles from Lymn, and where he was at that time informed "the keepers were destroying the herons as their noise disturbed the game." Most happily such an atrocity was never perpetrated, and as a fitting appendage to the sporting estate of his Royal Highness the Prince of Wales, there is little doubt that right royal protection will be extended to this thriving colony, which could boast some twenty nests in the spring of 1868.

To the Rev. T. Fulcher, of Old Buckenham, I am indebted for the knowledge of an incipient heronry in that parish, which commenced with one or two nests in 1864, in a small plantation of spruce firs, near old Buckenham lodge, belonging to $\mathrm{Mr}$. R. Reeve, who is very anxious to preserve them. Since that time the birds have returned each spring, but the nests have in no year exceeded five. In 1868 the young in four nests were all hatched off, but unfortunately in the preceding winter several of the old birds were shot by individuals more careful of their fish than of the heronry. The above, with a nest or two said to have been discovered in 1867, at Burnham Overy and East Walton, by Mr. Burlingham, of Lynn, are the only localities, as far as I can ascertain, in which the heron still breeds in Norfolk;

* In the L'Estrange "Household Accounts," occurs the following entry with reference to this very wood:- "Itm paid at Lynno when ye went on hawkying to Wolferton wood for fyer and dryncke." It is quite possible, therefore, that even at that time the Wolferton heronry afforded the noblest sport of the day to the squire of Hunstanton. 
but an old estiblished colony at Herringfleet, near Lowestoft, still exists on the borders of the adjoining county.* MIr. Frere, of Yarmouth, has moreover kindly ascertained the sites of three heronries which have been deserted within the last thirty or forty years. The first of these on the estate of Mr. Browne, of Thrigby, was visited by $\mathrm{Mr}$.J.H. Gurney about the year 1839, when some half-dozen pairs still nested there, but these were probably driven away by the rooks. There was also a small heronry at Norton Hall, near Loddon, some twenty-five years since of which no trace remains; and a rather considerable one at Clippesby, which was destroyed in 1834; since which time all the efforts of the present owner of the estate have failed to induce the birds to build there again. Another small colony at Claxton, near Reedham, latterly consisting of but two or three pairs, finally deserted that station about two years since.

The heron is one of our earliest breeders, and remarkable for the punctuality with which it revisits for that purpose its accustomed haunts. Mr. TyssenAmhurst in a communication to Mr. Gould's "Birds of Great Britain," states that "the Didlington heronry is regularly peopled within a day or two of the middle of February. There is then a great clattering of bills and flapping of wings, with other indisputable evidence of their having paired, and that the breeding season is about to commence. Early in March three or four eggs are laid, and by the middle of April the task of incubation has terminated, and the young are hatched." Usually between the 14th and 28th of April I have seen young herons in the down, about two or three days old, resembling exactly the four nestlings figured by $\mathrm{Mr}$.

* In Suffolk, also, not so far from our limits as to be quite out of reach, I am told by Mr. Alfred Newton of small heronries at Cavenham and Chippenham. 
Gould, which were sent him alive, from Didlington, by Mr. Amliurst; but I also saw some young ones in 1859 as early as the 26th of March, which shows, that like rooks and other birds they are in this respect influenced by mild or backward seasons. By the first week in March Mr. Newcome tells me he used always to have a flight at "passage" herons,* and for many years I have noted the appearance of these birds over the city not later than the middle of March, passing to and from the surrounding marshes to the heroniy at Earlham. Mr. Lubbock, as a proof of the extended flights occasionally made by these birds in search of food, states that formerly, at Keswick "the flounder, called provincially 'butt,' was often found under the trees in the breeding season," and adds "these butts must have been brought from Burgh flats at the back of Yarmouth;" this, however, though by no means improbable, camnot be accepted as a fact, inasmuch as Mr. Gurney has known small flounders to be taken as high up the Norwich river as the New Mills. It is also remarkable, as noticed by Messrs. Gurney and Fisher, "that when the herons drop any of the food, which they bring to their young amongst the trees of the heronry, they make no attempt to recover it, but, probably from a consciousness of their inability to rise from the ground in a confined space, allow it to remain where it falls." Thus the Earlham keeper tells me he has frequently picked up large eels and other fish in a perfectly fresh state,

* "Passage herons" in falconry are those at which hawks are flown as they pass overhead, either to or from the heronry, generally at a great height. In the old days of the sport, the more usual mode was to spring the heron from the water-side and let loose the hawk at it as it rose, The quarry then speedily took to the water again, and the whole "flight" as may be easily imagined was of a character quite different from that of the aerial combat of modern times. 
but when the nests are numerous, the stench from this waste food is extremely offensive. Two broods are usually reared in the same year, and, according to the authors above quoted, "a notion is prevalent amongst the country people that the second set of eggrs is incubated by the young of the first brood."* Young herons, as Mr. Gurney informs me, are excellent eating just before they leave the nest, but afterwards become both poor and fishy.

That the heron attains occasionally to a great age and yearly visits the same breeding place, has been satisfactorily proved in more than one instance, through birds being taken with a thin copper plate attached to the leg bearing the date of some former capture. In 1844, according to Messrs. Broderick and Salvin, $\dagger$ a heron, on its "passage" to the Didlington heronry, was taken by Mr. Newcome's hawks near Hockwold, bearing a label with the inscription "Colonel Wilson, Didlington, 1829," proving that it had been caught in the same neighbourhood fifteen years before; $\ddagger$ and this same bird

* Mr. F. Frere, on a recent visit to the Fritton heronry, was informed by the keeper that " the birds lay a first clutch of eggs, which take three weeks to hatch; after about a fortnight they lay as many more, which are hatched off with the young birds in the nest."

† "Falconry in the British Isles," p. 75, pl. xxiv., fig. 1.

I A similar instance, showing a far greater age in the bird taken, is thus recorded in the "Annual Register" for the year 1767 (p. 107), under date July 7th:- "As the Prince Stadtholder [of Holland] was taking the diversion of hawking, he caught a heron with a brass inscription round his legs, setting forth that he was taken and released by the elector of Cologne in the year 1737." In Colonel Hamilton's "Reminiscences of a Sportsman" (vol. ii., p. 218) a grey heron is also stated to have been "shot in the Habra, a subdivision of Oran in Algeria," in 1858, which had attached to one of its legs " a copper ring, bearing the Royal crown of Holland, and, in English, an inscription "Royal Harrking Club, 18.50, Loo, Netherlands." 
having, singularly enough, been eaptured the previous year by Mr. Newcome, was released on the last occasion with three rings on its legs.

I can certainly confirm, from personal observation, the statement of $\mathrm{Mr}$. Knox, ${ }^{*}$ that the parental duties of the heron "so far from being relaxed after sunset appear to be redoubled during the night," as I have heard them at all hours when spending a night on the broads in the early summer, and have started them one after the other from the water's edge with the earliest darnn of morning. Judging from those I have seen at Earlham, the young appear to remain very late in the nests, but after they leave their homes and before they acquire the full power of flight, they are fed on the ground by the old birds, and when thus collected in little groups are extremely picturesque. As soon, however, as they are able to forage for themselves, they disperse over the surrounding marshes, and many fall victims to the marsh gumners, being then but little suspicious of danger, after the protection hitherto afforded them. By the midale of July young herons, in parties of eight or ten together, may be seen fishing in the marsh "dykes" about Coldham-Hall, not unfrequently within shot from the river; and the shallow waters of Surlingham and Rockland broads are a constant resort.

In autumm they visit the inland Meres to feast on the eels which abound in those waters, and are then too frequently shot by the keepers; but at Scoulton, they would be far better encouraged than destroyed, inasmuch as the eels (as I shall hereafter have occasion to show) are destructive to the young of the black-headed gulls. I never remember to have crossed Breydon winter or summer, at low water, without seeing one or more herons on

* "Ornithological Rambles in Sussex." By A. E. Knox, M.A., F.L.S., \&c., 3rd ed. p. 34 . 
its extensive mud flats, either patiently waiting their prey, knee deep in the narrow creeks, or in the act of killing a freshly caught eel, by knocking it repeatedly on the ground. Sometimes, also, they may be seen grouped together in every conceivable attitude waiting: for the fall of the tide, reminding one of Mrs. Blackburn's clever sketch of herons on the shores of Locheil. Next to Breydon muds, Blakeney and Salthouse are perhaps their most fuvourite resorts by the sea, as I have never visited either place without seeing one or more even in July and August, and at Salthouse Mr. Dowell once saw a flock of fourteen.

In such localities, at almost all seasons, they frequent the salt marshes, backwaters, and sandy flats, or, perched on the seaward side of a mussel-scalp or projecting spit of shingle, reluctantly leave their post, only when the sea washes the under parts of their plumage, * and this more particularly in winter if frozen out from their inland haunts, when, unfortunately, during severe weather a considerable number are killed; and though no longer esteemed as an article of food, $†$ find their way

* In the "Zoologist" for 1866 (p. 95) Mr. Blake-Knox states that from the New Bridge at Wexford, he observed a singular habit in the heron. "Some were lying in the water, the head and neck only emerging; there was about a foot of water on the Ooze."

+ In former times the heron ranked no less high as a delicacy for the table than as an object of sport, and whilst a heron tuft was a badge of honour, no royal banquet was complete without a bird or two occupying the chief place at the board. According to Folkard, in Edward I. reign, the price of a heron was higher than that of any other wild fowl, from sixteen to eighteen pence, the latter for the young birds. In the Lord North "Accounts," at the Kirtlinge festivities during Queen Elizabeth's visit, "xxviij hearnshewes" were supplied at "iiijli. xiijs. iiijd."; and in the Northumberland "Honsehold Book" it is ordered that "Hearonsewys be bought for my Lordes own Mees, so they be at xijd.a 
to our poulterers' shops, or the older specimens pass into the hands of the birdstuffers.

It matters not where, or how, the heron presents itself-whether standing motionless in some marsh drain, with the head drawn back for its unerring aim; whether soaring high over head, with laboured flight, bearing food to its young, or launching itself on the wing from some such quiet nook on the broads, as is so exquisitely depicted in one of Yarrell's vignettes (2nd ed., vol. ii., p. 640)-still, wherever seen, in the open country, or on the lofty fir or ash trees of its adopted home, this species is always a striking object, and one that, from its picturesque beauty, we could ill spare from our rural scenery. The voracious appetite ${ }^{*}$ of this species, however, and its predilection, as a fish-eater, for preserved waters, too often ensures its destruction by the gun or a baited hook, as a well stocked fish pond will be visited again and again by the same bird; yet in reality the injury it inflicts is much less than is commonly supposed, and it is only in very shallow water that injury at all is done, while the heron, from its feeding on water-rats and water-beetles (two great enemies of young fish) is often a positive benefactor. To the decoyman, as Mr. Lubbock remarks, it is a great nuisance, disturbing the wild fowl

pece." The following entries in the L'Estrange's "Accounts," also, mark the appreciation in which heron's flesh was then held:-

It. a hernsewe and xij rabbits of store.

It. ij hernsewes and xij rabbetts of store.

Itm a pygge iij hernsewes and xvj rabbetts of store.

It. a fawne and ij hernsewes and xiiij rabbetts of store.

It. viij malards, a bustard, and j hernsewe, killed wt ye crosbore.

* Bishop Stanley, in his "Familiar History of Birds," states that in the stomach of a heron, picked up dead on the banks of a stream in Scotland, were found "the extraordinary number of thirty-nine fine trout." 
by stalking amongst them when asleep on the "banks" during the day, and from its acute sense of hearing, giving the alarm long before the fowl near the "pipes" are conscious of any danger. To the punt and marsh gunner, also, it is equally obnoxious from the same cause, its loud "frank," "frank," as it slowly flaps over the ooze, being evidently received as a "caution" by all other wild fowl. Of fresh water fish the heron is particularly partial to pike, and in Norfolk, says $\mathrm{Mr}$. Lubbock, "gets half its subsistence from the fry of this fish; those which were taken by the falcons at Didlington had always small pike in their maws." On one occasion Mr. Newcome saw a heron plunge head first* into a marsh "dyke," some five or six feet deep, and emerge again with a pike in its beak, weighing from a pound and a-half to two pounds, which he secured directly after the bird had killed it. He has likewise taken a pike of that size from the stomach of a heron, which had been seized by his hawk as soon as it rose.

Fish, however, compose a portion only of a heron's food, as I have ascertained repeatedly by an examination of the contents of the stomach. In some, balls of fur, as much as two inches in diameter, have attested their extreme partiality for water rats, these pellets being thrown up after the manner of hawks and owls; and mingled with this mass have been also found the slimy remains and small white bones of the frog, fish scales, portions of eels, and fragments of water insects, such as water-beetles and boat-flies. In confinement it is well known to devour small birds, feathers and all, and on the broads and rivers, the young coots and waterhens

* 'This habit is also alluded to by Messrs. Sheppard and Whitear, who state that a heron, observed by them standing on the steep bank of a river " in darting at a fish, precipitated himself into the water, but was out again in an instant with its prey." 
are, no doubt, similarly disposed of when opportunity offers. In the summer of $1847 \mathrm{Mr}$. Rising, of Horsey, disturbed a heron by the water's edge, which rose with something in its beak, but having dropped its prey before it had flown far, Mr. Rising secured it, and found it no other than a young water rail, freshly killed and bleeding about the head. Mr. Newcome also tells me that during very severe weather he once saw a heron pick up something from the ground, and fly off with it for about a hundred yards, when it again alighted and began tumbling about in a very strange manner. On running up he was just in time to shoot a stoat that the bird had swallowed alive, but which it was only too happy to disgorge as quickly as possible.

Whether any portion of our Norfolk herons proceed further south in severe winters, or more northern residents visit our shores, I have at present no certain evidence, but $\mathrm{Mr}$. Frere is informed by a very trusty Yarmouth gunner that he has seen the heron when at sea, thirty miles from land, and that he last year (1867) shot one in November.* At Yarmouth, as Captain Longe informs me, it is not an unusual thing to see herons flying direct out to sea, but at low water it is probable that the shoals and sandbanks, unhappily so prominent on our dangerous coast, and accessible enough to such long legged birds, might attract them for a change of fish diet; at Cromer, also, I have more than once watched a heron, through a good glass, coming in a direction from Yarmouth, and passing along shore with a slow steady flight, making for some point not nearer, I should imagime, than Salthouse or Blakeney.

The soaring flight of the heron, which Virgil, with

* Tho instance abore quoted (p. 139, note) seems to show that the Dutch herons emigrate to Algeria for the winter 
lis general accuracy of observation so aptly describes,* is always a grand sight to witness, whether ascending of its own free will beyond our powers of vision, or compelled to adopt its spilul ascent, as a means of escape, fiom the carrion-crow or other feathered persecutors. Under either circumstances I have watched at varions times the actions of this noble birk, and could but contrast the power and ease of its movements, when almost lost in the clouds, with its clumsy efforts to rise, and slow lahoured flight when abruptly disturbed in a drain, or from the side of a reed-bush. Herons are not, I believe, particularly pugnacious amongst themselves, but a singular occurrence at Roydon some years ago is recorded in the "Zoologist" for 1816 (p. 1212) by the Rer. H. T. Frere. A pair of herons were seen by a boy fighting on the ground, and on rumning up to them one flew away and the other lay still and allowed the boy to pick it up. He then carried it to a gentleman who examined the bird, and found it very little injured, and on being placed on the lawn to recover, it soon availed itseif of the chance, and, stretching its wings, made off altogether.

\section{ARDEA PURPUREA, Linnæus.}

\section{PURPLE HERON.}

It seems most probable from his minute description of the plumaget that under the name of "Black Heron"

$$
\text { * " notasque paludes }
$$

Deserit, atque altam supra volat ardea nubem."

Georg: Lib. i., 1. 363, 364.

† "Black on the sides, the bottom of the neck, with white grey oin the outside, spotted all along with black on the inside. A black coppe of small feathers some a span long; hill pointed and yellow, 
Sir Thomas Browne included the abore species in his "Account of Norfolk Birds," but even should this be so, he gives us no reason to suppose that it was then otherwise than an accidental visitani. Of recent anthoi's Selby is the first to mention the Purple Heron in connection with this county, stating in his "British Ornithology" that in the month of May, 1830, a fine male of this species, killed in Norfoll, came into his possession, * and its mate into that of Sir William Jardine. He also adds in a foot note, "since writing the above I have heard of three other specimens,- two killed in Norfolk and another near London." To this may be also added the testimony of the late Mr. Hoy, who, in recording the occurrence of an immature specinen in 1880 ("Mag". Nat. Hist.," new series, vol.i., p. 117), "near the mouth of the Woodbridge river in Suffolk," says, "I have also known two or three individuals to have been met with in Norfolk within a few years." The latter, as well as the two mentional in Mr. Selby's foot note, are no doubt included amongst those of which further particulars have been given by local writers. Mr. Hunt, under the name of Ardea caspia, or "African heron," records a specimen as shot "a few years since near Ormesby," which is no doubt the same bird which, in Sir William. Hooker's MIS., is deseribed as shot at Filby in 1810. In the same MS., also, under the name of the "African heron," the immature bird in the Norwich Museum (No. 202b), procured near Yarmonth, and presented by the

three inches long; back heron coloured, intermixed with long white feathers; the strong feathers black; the breast black and white, most black; the legs and feet not green, but an ordinary dark cock colour."

* Mr. J. H. Gurney, jun., who has recently had an opportunity of inspecting the late Mr. Selby's collection at Twizell house, informs me that it contains a fine adult purple heron, most probably the one sent from Norfolk. 
Rev. G. W. Steward, is stated to have been killed in 1831. From the Messrs. Paget we learn that two Yarmouth specimens were sent, one to Colonel MImtagu,* and the other, by the Rev. George Lueas, to the British Mruseum. Anongst other notes very lindly supplied me by $\mathrm{Mr}$. Joseph clarke, of Saffion WValden, is a notice of two fine specimens of this heron in the possession (18:31) of Mr. Stephen Miller, of Yarmouth, shot in that neighbourhood; and two were inchded in Mr. Miller's sale catalogue in 1853 , but I cammot assertain by whom they were purchased.

An immature bird in Mr. Spalding's collection at Westleton, was purchased by him at Yammouth between twenty and thirty years ago, and a magnificent pair, in full atult plumage, forming part of the late NIr. Lombe's collection at Wymondham, were both shot (as Mrs. Clarke informs me) on Oulton broad, near Lowestuft, in the arjonining county, the male in June, 18:3:, and the female on the 10th of September of the same year.

Of late years I know of but two specimens obtained in Norfolk, and both in immature plumige. Of these, the first was shot on Huvetun broud on the 1st of July, 1862, by Lord Lilford, who, with a small party, was "flapper" shooting at the time. On rising from a reed-bush it was at first mistaken for a bittern, but as it flew wounded romel the broal, it was recognised by him, from its reddish tints, as a purple heron; and on cautiously approaching the spet where it was seen to alight, the bird was found nearly dead. On dissecting this specimen, now in the possession of the Rev. T. J. Blofeld, at Hoveton, I found the body, both outside and in, immensely fat, and in the stomach were the

* Colonel Montagu's collection now forms part of the British series, at the British Museum, which, according to Mr. G. R. Gray's catalogue, contains tro specimens killed in England.

U 2 
remains of two good sized roach, one quite five inches long. As far as I could tell, owing to the shot marks, it was a young female, and presented the following appearance in its immature plumage. A slight red crest on the head, the dark lines down the front of the neck distinctly marked by young reddish feathers, just shooting, blended with black longitudinal blotches, becoming brown on the breast; cere (when dead) greenish; bill yellowish-green; quill feathers of the wings and tail perfect, of a purplish blue colour like the bloom on a plum; wing coverts and back tawny, but the hackles, just showing, of a reddish tint; the bare portions of the tibia bright yellow all round, the tarsi dark brown in front, the posterior portions yellow, as also the under surlice of the feet; the "feather-tracks" on the breast and on the lower part of the back composed of bright yellow patches of down-like floss silk.

Another young bird, a male, in my own collection, was purchased in the Norwich fishmarket by Mr. S. Bligh, on the 28th of October, 1865, where it was hanging up in a perfectly fresh state together with a fine bittern, and on enquiry both birds were ascertained to have been shot at Ludham a day or two before. This bird was also very fut, but weighed only two pounds three ounces, and the stomach contained merely a diry pellet of mouse hair, which, from a portion of the tail remaining in the pellet, was believed by Mr. Bligh to belong to the short-tailed field species.

The purple heron breeds in Holland in considerable numbers: its occurrence, therefore, on our shores, from time to time, is easily to be accounted for. 
ARDEA ALBA, Linnæus.

\section{GRAT WHITE HERON.}

I have felt some doubts as to whether this fine slecies can be fairly included in the Norfolk list, but on the whole, I think I should be least justified in onitting it. A fine specimen in Irr. Gurney's possession was purchased by lim, with other rurities (all of which he was assured at the time had been killed in this county) of the late Mr. Thurtell, of Eaton, when selling off his collection of Norfolk birds.* Another example of this bird, in MIr. Stephen Miller's collection at Yarmouth, was also sold in 1853 , but of its history, unfortunately, there is no record, nor an I aware in whose possession it now is. 'To this, however', may be added, on the authority of Mr. Joseph Clarlie, of Saftron Walden, that Mir. Miller once found "the wings and feathers" of a great white heron somewhere near Yarmouth.

The following instances of the occurrence of this heron in the adjoining county of Suffolk are thus given by Messis. Sheppard and Whitear:-_"On the 3rd of October last (1823 or 1824) in a walk on the banks of the river Stour, we observed a large White Heron cross over from the Suffoll to the Essex side of the river. It appeared to be pure white, and to stand up rather taller than some Common Herons which were feeding not far off. A similar bird was observed in the spring on the Oakley shores; and subsequently to our observation, one was seen on the banks of the river Orwell."

* Most of the rarer birds in Mr. Thurtell's collection were formerly in the possession of the late $\mathrm{Mr}$. Hunt, as $\mathrm{I}$ am informed by his son. But unfortunately the "British Ornithology" never having been completed, there is no letter-press to accompany $\mathrm{Mr}$. Hunt's clever drawing of the great white heron. 


\section{ARDEA GARZETTA, Linnæus.}

\section{LITTLE EGRET.}

This beautiful species has not hitherto been included in the list of Norfolk rarities; but whilst there is reason to believe that others have occurred, the following authentic instance fully entitles it to a place in the present work. In 1864, when staying at Worthing, Mr. J. H. Gurney was informed by Mr. Wells, a local birdstuffer, that he had recently seen a Little Egret, said to have been killed near Norwich, in the possession of Dr. Diamond, of Twickenham. Further enquiry fully confirmed this statement, and from the particulars kindly forwarded to me by Dr. Diamond, it appears that this specimen was sent him as a "strange bird" about 18:34 or 1835, by Mr. Roger Stoughton, of Sparham, who, as an old schoolfellow, under Valpy, at the Norwich Grammar School, knew his ornithological tastes. The bird was forwarded in the flesh, and was preserved by a birdstuffer who subsequently went to America and died there.

Mr. Clarke, of Saffiron Walden, who nearly forty years ago spent several winters at Yarmouth collecting natural history objects, and was well acquainted with all the local collectors at that time, was informed by the late $\mathrm{Mr}$. Leonard Rudd that the little egret was "sometimes met with near Yarmouth," and there is not much reason to doubt that the specimen sold in 1853, with the rest of Mr. Stephen Miller's Yarmouth collection was killed in that neighbourhood, but I cannot ascertain by whom it was purchased.

Mr. Lubbock refers to a statement in Loudon's "Magazine of Natural History" for 1836 (vol. ix., p. 320 ), by the Rev. E. Ventris, of Cambridge, wherein the writer says he had "recently been informed that 
this bird anmually visited Horsey in Norfolk, till about twelve years ago, and that since that time it has disappeared." Mr. Lubbock suggests that in this case a confusion has arisen between arocet and egret, which is, I believe, a plitusible explanation of so palpable an error, since there is no cause for supposing that the egret, rare enough as an aceidental straggler, was ever lnown to visit this county, or indeed any part of England regularly. In like manner one can but agree with Fleming and Selby that "the birds mentioned in the bill of fire at the famous feast of Archbishop Neville in the reign of Henry IV., under the name of Egrets or Egrittes,"-when "a thousand were served up at a single entertaimment," were not of this species, but merely lapwings, so termed from their crests; aigrette or egret signifying a tuft of feathers.

\section{ARDEA RUSSATA, Wagler.}

BUEF-BACKED HERON.

Like the two preceding species this heron is inserted for the first time in the list of our accidental visitants on the authority of $\mathrm{Mr}$. Joseph Clarke, who informs me that a young bird, killed at Martham, near Yarmoutli, in 1827, is now in the Saffron Walden Museum.

\section{ARDEA COMATA, Pallas.}

\section{SQUACCO HERON.}

This small but very beautiful species has occurred in the comty in several well authenticated instances, the earliest of which I can find any record being the one noticed by the Messr's. Paget as "caught in a 
bow-net that was hanging out to dry* by Ormesby Broad, in December, 1820." In Sir William Hooker's MS., however, althongh the same facts are stated, this bird is said to have been taken on the 11th of July, but I have reason to believe that the former date is correct, as Mr. Doweli† was informed by the present owner of this specimen, the Rev. F. Ensor, of Lustleigh rectory, Newton Abbot, Devonshire, that it was taken in the the winter. It was captured alive, but as its proper food was not known, and it refused to eat, it was killed after a day or two, and its skin preserved. According to Selby " two of these heions were lilled near Yarmouth in the month of May, 1831," and judging from local records there is no donbt that one at least of these birds is the one now in Mr. J. H. Gurney's collection, and formerly in the possession of Mr. Miller, of Yarmouth, which, as stated by Messrs. Paget, was procured at Oulton, near Lowestoft, in the adjoining county. on the 12th of June, 1834, a second example appears to have been obtained at either Ormesby or Filby, and purchased by Captain Chawner, of Alton, Hants, at that time collecting at Yarmouth; and in the same month, according to a note in the handwriting of the late Mr. Lombe, another was shot on Lake Lothing, near Lowestoft. He also mentions one as killed near Burlingham, Norfolk, but the date is not recorded.

* Mr. Gurney informs me that to the best of his belief a squacco heron was taken many years ago, in a fisherman's net spread on the beach to dry at Lowestoft or Pakefield.

+ See a minute description of this bird by Mr. Dowell in the "Zoologist" for 1843, p. 78.

‡ "British Ornithology," vol. ii., p. 26 (note.)

II In the notes supplied me by Mr. Joseph Clarke, the date of this bird is given as January 5th, but in this case the Messrs. Paget and Selby are most probably correct. 
Unfortumately it is impossible now to ascertain whether the two specimens in the late Mr. Lombe's collection at Wymondham, were procured in this country or were purchased abroad.

Since these earlier dates I know of no instance of the squaceo heron appearing on our coast till the year 1863, when, a fine adult male, in my own collection, was killed on Surlingham Broad, on the 26th of June. Being away from home at the time, I unfortunately had not the opportunity of dissecting this bird myself, nor can I say anything as to the colour of the bill, feet, and legs in a fresh state, but its plumage is extremely beautiful, and singularly minjured by the shot. John Trett, the marshman who killed it, described it as remarkably tame, flying round his boat, and alighting again on the marsh close to him, apparently interested in his movements; but the poor wanderer, as usual, received little welcome, even from its own race, as the rooks kept up a constant persecution.

In the "Zoologist" for 1865 is a notice by my friend Mr. Rocke, of Clungunford House, Shropshire, of a splendid adult male in his collection, which was purchased by him, in the flesh, of a London dealer, on the the Sth of July, 1864. This, he was informed, had been killed on the previous day by a gardener, near Yarmouth; my own enquiries, however, of Yarmouth gumuers and collectors, and Mr. Rocke's subsequent investigations led us at length to the conclusion that, even if procured anywhere in England (it being quite possible that such a bird could be received from the continent in a perfectly fresh state) it was certainly not killed in Norfolk. This example, from its perfect plumage was forwarded to Mr. Gould, who made a drawing of it for his fine work on the "Birds of Great Britain."

A very good specimen in the possession of Mr. Reginald Upcher, of Kirby Cane, was ascertained by 
him to have been killed many years ago at Flixton, near Bungay, Suffolk.

\section{BOTAURUS MINUTUS (Linnæus).}

\section{LITTLE BITTERN.}

Norfolk is not only remarkable for the number of scarce species known to have occurred within its boundaries, but, also, as in the present instance, for the number of specimens procured of birds, regarded as rarities in any part of Great Britain. No doubt from time immemorial the Little Bittern, as an occasional straggler, has sought shelter in the luxuriant herbage of the "Broad" district, nor is it at all improbable that this species may even have remained with us, at times, to breed,* having been found in pairs

* Although believing in the possibility of the little bittern having bred in Norfolk, I have no satisfactory evidence that the eggs have ever been taken, and I think it, therefore, the more necessary to refer to a note in the Huddersfield "Naturalist" for 1866 (vol. ii., p. 366), in which Mr. R. B. Sharpe states that he had just added to his collection "the following genuine eggs collected in Norfolk last season by a gentleman," viz., the yellow-billed cuckoo, rock thrush, little bittern, golden oriole, roseate tern, and sandwich tern. This marvellous statement, so strangely differing from my local experience, led to further correspondence (vol. iii., pp. 22 and 45), and the discovery that the genuineness of these rare Norfolk eggs rested solely on the word of a London dealer, the gentleman who collected them liaving most conveniently left for Norway. Norfolk is unquestionably a rich ornithological comnty, and a most likely district for any mendacious dealer to assign for rare eggs or birds which he desires to palm off as British, but the selection, in this instance, was particularly unfortunate, inasmuch as neither the yellow-billed cuckoo nor the rock-thrush lave yet been observed in Norfolk; the rosente tern is only once recorded 
during the summer months, and, in one instance, a perfect egg was taken from a female killed near Lowestoft. Its skulking habits, however, and the almost impenetrable nature of the swamps it frequents renders detection, except by the merest accident, extremely improbable. Of its identification in this county, I find no record prior to the commencement of the present century, but in Messrs. Sheppard and Whitear's catalogue it is first mentioned, a specimen having been killed at Burlingham in the winter of 1819 , as those authors were informed by Mr. Hunt of Norwich. Next in point of date is most probably the male bird, stated by Mr. Lombe* in his MS. notes, to have been killed at South Walsham, in May, 1822.

Of the three specimens enumerated by the Messrs. Paget in 18:34, the first, as stated by Yarrell on Mr. Lubbock's authority, was an immature bird "caught by a water-dog, at Hickling, near Ludham, during the extreme frost of 1822-23," and presented by Mr. Lubbock to the late $\mathrm{Mr}$. Girdlestone. The second, which formed part of the late Mr. C. A. Preston's collection (now in the possession of $\mathrm{Mr}$. E. S. Preston, of Yarmouth), is described by the Messrs. Paget as laving been killed at Lowestoft in June, 1830, and is, very probably, the same mentioned in Mr. Lombe's

to have been seen; the sandwich tern visits us merely in spring and autumn, and the only record of the golden oriole remaining here to breed is extremely doubtful. Nor could I ascertain that the little bittern had been either heard or seen in any part of the county in the year 1865 . I have reason to know that $\mathrm{Mr}$. Sharpe is fully convinced that in this instance he was grossly deceived, and, as a zealous ornithologist, regrets that he ever appended his name to so doubtful a statement.

* There is no evidence to show whence Mr. Lombe procured the pair, which are still preserved in his fine collection at Wymondham. 
MS. notes as shot at Oulton, near Lowestoft, in May of that year, whilst the third, said to have been shot at Barnaby to which no date is attached by the Messrs. Paget, is no doubt the adult male which, as I learn from Mr. Joseph Clarke, was shot near Yarmouth in 1833, and formed part of Mr. Miller's collection. Dr. Diamond, of Twickenham, the fortunate owner of the Norfolk little egret, also informs me that he has two little bitterns, killed near Bawdeswell, in this county, which were purchased and sent to him by his friend, the late Mr. R. Stoughton, of Sparham, somewhere about the year 1834 .

To Mr. J. H. Gurney, jun., I am indebted for the following extract from a letter addressed to Mr. Henry Doubleday, of Epping, by the late Mr. Heysham, and dated Carlisle, September 25th, 1839 :- “ From a letter which I received a day or two ago from a friend* in Norfolk. * * * I find that a very fine pair of adult little bitterns were killed at or near South Walsham, about two months ago. It is generally supposed that these birds had a nest when captured." Mr. Yarrell also records this pair on Mr. Heysham's authority; and, as Mr. Gurney (in whose possession they still remain) informs me, they were killed by the marshman [Samuel Ebbage], who then had the care of South Walsham broad; the man, I believe, who killed on the same broad the pair of Savi's warblers, in the Norwich Museum. By lim they were sold in the flesh to Mr. G. Johmson, then a birdstuffer, in Norwich, and it was from Ebbage's statement to Johnson that the birds were supposed to have had a nest. A male bird, also, in Mr. J. H. Gurney's collection, and formerly belonging to the late Mr. Thurtell, of Eaton, was said

* The friend here alluded to was no doubt Mr. J. H. Gurney, senior, at that time in frequent correspondence with Mr. Heysham. 
to have been killed near Yarmonth, but the exact date is not known. Mr. Rising, of Horsey, has a pair, which he belieres were killed at Herringfleet, near Lowestoft, some year's since, but whether identical with any I have already enumerated I am unable to determine. On the same authority, however, I may add that a pair of these birds between the years 1824 and 1829, frequented some swampy ground adjoining the parsonage at Catfield, from which locality some eggs, resembling those of the little bittern, were taken at the time by the then Curate, the Rev. James Layton, by whom they were shown to $\mathrm{Mr}$. Rising. Mr. Rising also informs me that in February, 1842, a little bittern was shot on his Breydon marshes, but of this I can find no further record, and the occurrence of another specimen at Sunth Walsham, about the 11th of June, 1849 (in the possession of the Rev. J. Burroughes, of Lingtrood), is thus noticed in the "Zoologist" for that year (p. 2498) by the Rev. H. T. Frere,* "On two or three successive nights, when sailing on the broad, we had heard a noise in the marsh at the side, resembling the bark of a dog, or more nearly the grunt a pariour gives when dropping his rammer. Though all the party were tolerably well acquainted with the notes of the marsh birds, this was a novelty to us. A marshman, however [the one before mentioned], recognised it as the note of the little bittern, one of which (at present in the possession of Mr. Jary, of South Walsham) he had shot some thirty years before. I sent him a message offering him a price for the bird, and on Saturday night or early on Sunday morning he shot it, but took it to another person and

* The same bird, recorded in the "Zoologist" for 1851 (p. 2989), by MIr. J. O. Harper, as "a beautiful male, preserved by Knight of Nortrich," 
sold it for the price I had offered, much to my annoyance and disappointment. It is something, however, to have heard this rare bird. When he shot the other it was after several attempts to get it to rise, in which he had failed; he then waited, and about four o'clock in the morning it rose spontaneously."

There is a notice, also, in the same volume of the "Zoologist" (p. 2528), by Mr. J. Smith, of Yarmouth, to the efrect that three specimens of the little bittern had been shot in the marshes, near Yarmouth, during the spring of 1819 , but no further particulars are given respecting them. In a recent visit, however, to the Bury Museum, I found an adult female of this species amongst $\mathrm{Mr}$. Demnis's birds, which, in the memorandum attached, was said to have been killed at PotterHeigham, on the 18th of May, 1849, and it was also stated that a male had been shot, at the same place, on the following day. These I have no doubt are two of the birds referred to by Mr. Smith.

On the 17th of May, 1852, as recorded by Mr. Gurney in the "Zoologist" (p. .3503) a young male that had nearly completed the assumption of the adult plumage was killed at Somerton,* one of the smaller broads. This specimen, which is preserved amongst the British birds in the Norwich Museum (No. 207) is described by Mr. Gurney as having been in good condition, with the remark that "the stomach contained the caudal moiety of a roach, the anterior portions of which appeared to have been digested, but which, when entire, must have been four inches long besides the tail."

Again, in the first week of December, 1856, another

* This is evidently the same bird which was erroneously recorded in the "Naturalist" of that year (p. 252), by Mr. J. O. Harper, as killed at Somerleyton, near Lowestoft, a far less likely locality. 
specimen, killed in MIr. Heath's marshes at Horning, was sold in Yarmouth to some local collector, and on the 3rd of Sutember, 1864 , the last that has been observed in this county was shot off a "rand" on Horsey Mere. This bird, which was in perfect plumage, was sent to London by Mr. Rising, to be stufferl, but he assures me that the specimen returned to him, as his own, had not the slightest resemblance to the one he forwarded, which he has never been able to recover.

From this list of some twenty specimens, all procured within the bounds of the "Broad" district, either in Norfolk or Suffolk, it will be seen that taking only the cases in which the exact dates are known, no less than nine have been killed churing the stmmer months (May, June, and July); four in winter (December and February); and one only in autumn (September). With reference to the somewhat puzzling plumage of this species, Messrs. Gurney and Fisher remark that, "from an inspection of the specimens obtained, from time to time, in this district, we incline to the opinion that, if the females of this species ultimately arrive at a plumage similar to that of the adult males, as is asserted by modern naturalists, it is only at a much more advanced period than that at which the same plumage is assumed by the latter, and it appears quite certain that the female in the supposed immature plumage pairs with the adult male."

\section{BOTAURUS STELLARIS (Linnæus.)}

\section{COMMON BITTERN.}

It is a remarkable fact, as I have before stated, that of the rarer species recorded by Sir Thomas Browne as nesting in Norfolk in 1671, but two, the spoonbill 
and the cormorant, had ceased to do so at the commencement of the present century. But whilst from this time we must date those agricultural changes which were destined to alter the general aspect of the county, it was not until within the last five and twenty or thirty years that these, combined with other causes, resulted in the extermination of so many resident species. Amongst our marsh-breeders the curtailment, and in some places total reclamation of their haunts through drainage, has been the main cause of extinction, but the increasing demands of collectors, of late years, and the high prices given for both birds and eggs-the cheapness of firearms, and rapid trainsit by rail to all parts of the kingdom, affording every facility-have conduced not a little to the sime end, and former residents, receiving additions to their numbers in autumn and winter, can be described now only as migrants, perhaps occasionally remaining to breed. As such the Bittern alone holds its place amongst the birds of Norfolk at the present time, althongh, like the heron, entered as "common," in Hunt's List in 1829 ; and our sexagenarian sportsmen well remember the time when they used to flush both young and old birds from the reed-beds whilst flappershooting in the early autumn.

Mr. Lubbock, whose residence for many years in the neighbourhood of the broads, renders his admirable description of the habits of our rarer marsh-birds of peculiar interest, writes in 1815, "the bittern has decreased much in number in the last twenty years. I remember when these birds could be found with certainty in the extensive tracts of reed about Hickling broad and Heigham Sounds. Four or five might be seen in a morning. The nest and young of this species appear to lave been always difficult to find. After diligent enquiry, I could ascertain only two instances in 
which the nest had been seen with the young." * * * The want of actual knowledge of the nest itself does not in the least invalidate the fact of the bird breeding with us. A water dog once brought me a very young bittern, but, from the precarious nature of the reed-bed, and the difliculty of moving even a few yards further, I could not discover the nest whence he took it."

It is of course, from this very reason, extremely difficult to say when the bittern actually ceased to be a resilent in the "Broad" district, but from the time I commenced making notes on the birds of this county in 1850, until the year 1866, I conld not ascertain that any one had either seen or heard a bittern during the summer months, and as there are still marshmen in those parts well acquainted with their former haunts and habits, I believe the market price of such eggs from any British locality would, in spite of all difficulties, have resulted in a "find," had a pair of birds remained.

For at least fifteen or sixteen years, then, prior to 1866, I believe this species had altogether deserted us during the breeding season, but in the summer of 1866, the "boom" of a bittern was again heard on Horeton broad, and the birds themselves were recognised by William Hewitt, who, as marshman and leeper to the Rev. T. J. Blofeld, had every means of observing them. No nest appears to have been found, but from enquiries made in that neighbourhood, at the time, by my friend Mr. G. G. Fowler, it is most probable that they had selected the Woodbastwick side for their home, ranging from thence over the two Hovetons.

On the 12th of June of that year, it was my good fortune, by the merest accident, to see one of them, though at the time quite unaware that their presence in that neighbourhood had been detected by any one. Through the kindness of a friend, I had 
been enjoying a short cruise on the Bure and its tributaries, and on that day following its tortuous course above Acle Bridge we chanced to arrive, late in the aftemoon, at a point of this narrow stream where Wroxham on the one side and Hoveton on the other give the impression, almost, of one vast broad bisected only by a navigable channel. Here, conveniently moored against a broad dry "rand" the "Ripple" was made snug for the night, and whilst the slipper busied himself with culinary operations, I took my stand on the cabin roof to obtain a more extended view of those picturesque waters. Presently as I was watching the actions of a pair of great-crested grebes, alternately diving and preening their glossy feathers, a litrge bird rose from a dense reed-bed on the Hoveton side, and flapped slowly over the water to a similar shelter opposite. There was no mistaking it, though I had never before seen a bittern on the wing, and I anxiously waited for another chance of confirming my impression. In less than a quarter of an hour it rose again, and having my glass "well on" as it flew, heronlike, back again to its former covert, the colour of the plumage together with the rounded form of the wings, left no doubt on my mind; and on subsequently informing $\mathrm{Mr}$. Blofeld of the fact, I learnt that its peculiar cry had been heard prior to my visit.

The sight of a bittern on the wing, with all the accessories of that wild watery waste, is one, now-adays, at least, not likely to be forgotten by the most indifferent observer, much less an ornithologist; but there are other circumstances connected with that particular evening which have indelibly impressed the novelty on my mind. Still waiting and watching in the vain hope of witnessing a third flight, my attention was arrested by the rich crimson hue that had gradually pervaded all the clouds to the eastward, and turning I 
beheld one of those marvellous sunsets for which the flat waters of this county have been always celebrated.*

In the foreground a green belt of reeds and sedges fringed the wide expanse of Wroxham Broad, across whose rippling waters flashed a light pathway as of molten gold; and as onward and upward the eye sought to trace out that heavenward track to the focus of all its brightness, the limit of human vision was reached in one transplendent halo. Just then, as if to add a further charm to that which in itself appeared perfection, a rainbow of unusual brilliance spanned both broads and river; its noble arch being only less vividly reflected on the clouds beyond.

It were vain, indeed, to attempt by pen or palette to depict that glorious sky, but looking far into the vista of orange-tinted clouds, opening out, as it were perspectively, into untold glories, a strange yearning: seemed to possess one's mind, and thoughts, too deep for utterance, were symbolized only in the " $\mathrm{O}$ ! how heavenly!" of our finite judgment. Yet, already, whilst wrapt in the contemplation of that gorgeous spectacle, a change, gradual though not unfelt, was stealing over the scene, and as the cool greys once again took the place of the rose-colour and the violet, and the orange and crimson became absorbed, one turned, almost with a shudder, to the now cold dark stream, and with a chilling sense of exclusion came a marvelling as to those things which "eye hath not seen nor ear heard," nor the heart of man hath virtue "to conceive."

Although remaining on board the boat that night, with the hope of hearing its booming notes, the bittern did not gratify me in that respect, and probably, after sumset, took flight to some distant part of the

* See Walter White's "Eastern England" and Nall's "History of Great Yarmouth." 
broad. In the following summer, one if not two pairs remained in the same locality, notwithstanding that a single bird had been unfortunately shot during the previous season; and on visiting the Hoveton gullery, on the 7th of May, Hewitt pointed out to me the spot where he had seen one on the 13th of April. The Rev. J. Burroughes also informs me that he both heard and saw one there about the same time. No nest was found, but though left, I believe, quite undisturbed in their summer quarter's, I fear they must have been killed during the following winter, when two or three bitterns were shot in that neighbourhood, as I cannot learn that they have since been either heard or seen.

The summer of 1868 was, however, remarkable for the discovery at Upton, near Acle, one of the smaller broads, not only of two eggrs of the bittern, but subsequently of a young bird taken alive in its first plumage. The eggs, as stated in the "Zoologist" (s.s., p. 1221), by Mr. T. E. Gumn, of this city, in whose collection they still remain, were in a perfectly fresh state when taken from the nest (two only had been laid) on the 30th of March, and were exhibited by him in the yelk at a meeting of the Norwich Naturalist Society on the 6th of April. From the labouring man, of whom they were purchased, Mr. Gunn ascertained "that the old birds had been observed for some time past in the vicinity of the broad, and, from their appearance and manners, he suspected they had nested or were preparing to do so." The nest was composed of reeds and sticks. Of the genuineness of these eggs, there can be no question, although the rarity of the occurrence caused some doubts at the time. In size they are, if anything, somewhat larger than the generality of the eggs of this species, but one, as correctly stated by $\mathrm{Mr}$. Gumn, "is a trifle bigger than the other, and presents a beatiful oval form; the other tapers more at the ends, particularly at one end." Still, 
if further confirmation of their identity were wanting, we have the finct, that a young bird, canght alive in the very same locality, on the 25th of Haly, was purchased by Mr. Cole, a bird preserver, in Norwich, on the 28th, and sold by him a few days later to Mr. F. Bell, jun., of the Bracondale nursery. From a comparison of the above dates, there can scarcely be a doubt, I think, that this nestling, which, when first seen by my friend $\mathrm{Mr}$. Southwell, on the 10tl of June, appeared abont a month old, was the result of a more successful attempt on the part of the same old birds to rear their ofrspring. When captured it was partly in the down, but on the 10 th of June, Mr. Southwell found the wing feathers well formed and about half grown, only a patch of down remaining at the back of the head. Owing to my absence from Yorwich, I was unable to visit this most interesting bird until the 26 th of June, when all traces of down had disappeared, and a slight crest was perceptible about the hear, but the quills of the primaries still exhibited a very juvenile appearance. It appeared to be in good health, and fed heartily on small birls and fish, young frogs, raw meat, and worms; * in fact seened not at all particular as to its riet. Before strangers it was extremely shy, endeavouring to hide behind any object in its cage, and when in action, from its stealthy movements and outstretched neck, resembled some

* Sir Thomas Browne mentions one "kept in a garden for two years," which was fed on "fish, mice, and frogs; in default whereof, making a scrape for sparrows and small birds, the bitour made shift to maintain herself upon them." In like manner in "British Birds in their Haunts," by the Rev. C. A. Johns, a captive heron is described as perching on an old carringe wheel in the corner of a court yard, and lying in wait for sparrows and martius. On one occasion it was seen to pierce a martin as it flew past, and having plunged its prey several times in a water-trough, swallow it entire. 
large species of rail. Failing to find sufficient shelter, it would take refuge in one corner, and crouching down on its tarsi, face the intruder with the most peculiar, not to say comical expression. As in Mr. Gould's clever drawing in his "Birds of Great Britain," the head and neck were drawn back into its shoulders, with the throat and beak raised, almost perpendicularly, whilst from near the base of its sharp mandibles, a pair of keen eyes were directed forwards and downwards, which, from whatever side approached, seemed always fixed on one's own. This bird was still in good health, though in rather ragged plumage from its restless habits, when I last saw it on the 1st of October.

Hitherto I have spoken only of the bittern as a denizen of the broads, but there is reason to believe that it was formerly even more abundant still in the Hockwold and Feltwell fens in the south-western part of the county. There, as Mr. Alfred Newton was informed in 1853 by William Spencer, * a thatcher, at Feltwell, whose great-grandfather, grandfather, and uncle have all been gamekeepers in that neighbourhood, "bottleybunps" used to be extremely plentiful, selling like snipe for one shilling a piece. His grand-father used to have one roasted every Sunday for dinner, and they would lie in the sedge (which was in places five or six feet high), till they were nearly trodden upon. They were most common about Popplelot, and his uncle once shot five in one day. Drainage, however, and an exterisive reclamation of marsh ground has long ago expelled them from these once fuvourite haunts, with the ruffs, redshanlss, and black-terns, their former companions, and now only an occasional straggler is seen during the winter months.

* The same man whose evidence as to the heron nesting on sallow bushes, in Feltwell fen, has been given at p. 132, note.

+ Bottle-bump, or Bottleybump, a provincial name for the bittern, so termed, no doubt, from its peculiar cry. 
As Mr. Lubbock remarks, the known instances of either nests or young of this bird having been found are somewhat rare, but to those cited in his "Fauma" may be added the notice by Messrs. Gurney and Fisher of a young bird* taken by Mr. D. B. Preston many years ago, together with an addled egg, from a nest at Runworth, a broad specially mentioned by Messi's. Paget as a breeding haunt of the bittern, and where, according to the late Mr. Girdlestone's notes, a bittern was once shot on the 11th of May, in the act of feeding her young. Mr. A. Newton is in possession of a bittern's egg, obtained from Mr. E. S. Preston, who assured him that it came from the collection of the late Mr. John Smith, of Yarmouth, and that it was taken at Horsey, in 1841.† A very interesting account also of a young Norfolk bittern, from the pen of Mr. Jecks, of Thorpe, near Norwich, is published in a small work by the Rev. E. S. Dixon, formerly of Cringleford, on "the Dorecote and Aviary.f This bird, was picked up alive by a wherryman, in some marshes near Yarmouth, about the year 1845, and was in an unfledged state. It was extremely shy at first and refused all food, but eventually took kindly to a fish diet, and when once settled in its new home became very pugnacious, and would snap its beak viciously at all visitors, but proved an arrant coward when resolutely approached. It would eat fish and small birds, swallowing the latter whole

* See "Zoologist" for 1846, p. 1321, where a figure of this young bittern is given in Messrs. Gurney and Fisher's paper on the "Birds of Norfolk."

† Mr. A. Newton has also another British bittern's egg, which formerly belonged to Mr. J. Wolley. This was taken with three others in 1849 or 1850 , on the borders of a reservoir, near Tring, Hertfordshire.

‡ "The Dorecote and Aviary," by the Rev. E. S. Dixon, M.A., London, 1851. 
with all the feathers, and ocensionally an entire rat. It died in the severe winter of 1817 ; it was presumed from cramp, but from its unsociable nature was but little regretted. "During the calm summer nights," writes Mr. Jecks, "I was frequently awoke with its very peculiar ery or boom; this call was continued for about two months, June and July, and nearly all night-'boom'! 'boom'! - in a loud yet pleasant tone. Some owls that were confined near him also did now and then to the moon complain, on which occasions the bittern would swell its voice to its utmost power, trying to drown their more feeble cries."

In Mr. Gurney's collection are three nestling bitterns, which were purchased by him of Mr. Knight, of Norwich, either in 1847 or 1848. Mr. Knight reeeived them in the flesh, and when recently stuffed they passed into Mr. Gurney's possession. I camot now ascertain the exact locality from whence these birds were taken; but it was either Surlingham or Ritnworth, the latter being by far the most likely.

The Rev. J. Burroughes who, as an old sportsman in this county, has had much experience in marshshooting, assures me that he has killed many bitterns in his time, both in the early autumn and in winter, and has also seen their eggs from various localities. Messrs. Sheppard and Whitear likewise speak of receiving the eggrs of this species from marshes in Norfolk.

William Hewitt, of IIoveton, informs me that he once found a bittern's nest, miny years ago, when searching for leaches in the moist bottoms of the coot's nests, and in the bittern's nest he likewise found three.* On one occasion he surprised a bittern in a reed bush, in the very act of booming, with its head and neck

* I once took a leach from the stomach of a bittern, which lived in water for some time afterwards. 
straight up, as one might naturally suppose, and not buried in the mul or the hollow of a reed stem, after the quaint conceit of former naturalists. A remarkable fact, also, with reference to the nesting habits of this species, is mentioned by Mr. Lubbock, who states that in two instances in which four young were discovered in the nest, "two were apparently much older than the others." One pair being described "as more than half-grown, and the other pair covered with nestling down and but a few days hatched." Might not this be owing, as is here generally believed by country people to be the case with the heron, to the second set of eggrs being hatehed by the young of the first brood?

By some writers the bitteru is described as ascending at times in spiral curves like the heron, till almost lost in the clouds, ${ }^{*}$ but to this habit I can find no reference in our local authors; $M r$. Lubbock, however, states that one compelled to rise " in the full blaze of a July noon, flew hither and thither as if quite dazzled and confused by so much light."

As a migrant the bittern is a regular, and in severe seasons very numerous, winter visitant, a fact which has become much more apparent since its extinction as a resident species. Indeed, it is not improbable that in

* Thompson, in his "Birds of Ireland," assumes that from this habit, the bittern acquired its specific name of stellaris, but from the following note kindly supplied me by Mr. Alfred Newton, this term seems rather to have originated from its speckled or starry plumage. "Gesner, so far as I know the first man who called this bird stellaris, says, (Hist. Anim. iii., p. 208, ed. 1555) 'Ardea stellaris Aristoteli et Plinio memoratur, 'astepías Græcè cog. nominata, quòd punctis tanquam stellis eleganter picta distinctaque sit." "Aldrovandus in 1599, evidently quotes Gesner on this point; and Linnæus, who also quotes Gesner, adopted the name of stellaris. 
former times the number actually breeding in Norfolk was somewhat over estimated, owing to these foreign arrivals at the end of autumn, and it is not improbable that even the five bitterns shot in one day by Spencer's uncle were killed in the winter. Can nothing be done to stop the annual slaughter of such visitants as these? of which some ferw, I feel confident under a protective system, would still pretty regularly remain to breed with us. Unhappily the hoopoe in summer, and the bittern in winter, are par excellence the "raræ aves" of provincial journalism, and this, in spite of the negative evidence so fiequently afforded in our markets as regards the latter, by the sight of two or three exposed for sale at one time, which may be purchased at sums varying from one and sixpence to half a crown. My own notes during the last eighteen years are the most perfect refutation of the absurd notion that the bittern is a rare bird in Norfolk because it has ceased to breed with us, and although my list of examples killed during that period, contains only such as have come under ny notice,* from being either sold in our fishmarket or brought into Norwich to be stuffed, yet I was scarcely prepared to find them amount to one hundred and eight specimens. Of these the greater number have been killed on the large broads that border upon the river Bure, not far from the coast, as at Hickling, Horsey, and Heigham-Sonnds, or still further inland, about Wroxham and Hoveton, and occasionally at Barton and Ranworth. Many also have been procured from the smaller waters of Upton, Ludham, Sutton, and Stalham, but with the exception of the Burgh end of Breydon, they are but rarely met

* Captain Longe when residing at Yarmouth, assured me that he believed nearly every winter from ten to twenty bitterns were brought into Yarmouth from the broad district, and a dealer there once assured me that he had had twenty in two months. 
with on those broads, such as Surlingham and Rockland, which lie parallel with the course of the Yare. In the neighbourhood of Lynn they are in some seasons extremely plentiful, and specimens have been shot at times from the reed-beds on the Cley and Blakeney marshes. Amongst other localities, also, where chance stragglers have been met with, some of them at a considerable distance from the coast, may be mentioned Lakenham and Saxlingham near Norwich; Attleborough, Merton, and Briston; Gunton, Sherringham, and Beeston, near Cromer; and the Hempstead ponds, near Holt.

Of this number it will be seen by the subjoined table the chief bulk have appeared in mid-winter during, or immediately preceding, severe weather; and of late year's, the winters of 1853-54, 1854-55, and 1859-60, and still more recently of 1861-62, 1863-64, and 1866-67, have been remarkable for the number of these migrants killed in different parts of the county. No less than six were brought into Norwich for preservation, in one week, in January, 1864. I find but two or three autumnal stragglers recorded in my notes, all in the month of October, and of those killed in February and March, there can be little doubt that some, if undisturbed, would have remained to breed; whilst the one purchased in a perfectly fresh state in our market, on the 3rd of April, may even have had a nest at the time :-

October ...................... 3

November ................. 8

December ................... 35

Jantary ...................... 36

82

3
8
5
6

February ................. 15

March ...................... 10

April $\ldots \ldots \ldots \ldots \ldots \ldots \ldots \ldots, 1$

Total ........... 108

The difference in size of certain specimens is very marked, which, according to Montagu and other authors, is a sexual distinction, the females being z 2 
smaller than the males; and with regard to their plumage both very light and very dark varieties are observable amongst them, the former having the double line of markings down the front of the throat and neck, of a light reddish tint, the latter of a uniform dark brown, but the remainder of the plumage does not necessarily partake of the same hue. When freshly killed I have noticed a beatiful purplish bloom, as in old herons, on the feathers of the head and back, and the colour of the cere is then extremely vivid. I never remember to have observed the double iris in this species, described by Pennant, but Messrs. Sheppard and Whitear remark, "in one which we examined that [iris] near the pupil was reddish-yellow, the outer one hazel."

On the 7th of March, 1862, I examined two fine birds, which had been killed at a right-and-left shot, at Hickling, as they rose from the same tussocky mound, and from their thus lying together I expected to find them male and female. On dissection, however, they proved to be both males. These were in full adult plumage with a rich bloom on the feathers, and the markings of the throat in each of them was of a light reddish tint, with the upper portions of the plumage somewhat darker. They were about the same size, but one had the cere of a beautiful pink, whilst in the other the same parts were of the ordinary bluish horn colour. In the first the testes were extraordinarily developed, being an inch and three-quarters in length, and the whole breast and stomach was covered with perfect layers of fat. The other, in equally good condition, had much smaller testes, scarcely two-thirds of the former measurement; and in a third example, lilled about the same time, they were scarcely fiveeighths of an inch long. In the stomachs of these birds I found the remains of several eels, one nearly perfect, 
of about six inches, and a roach of five and a half inches in length, with the debris of water beetles (Notonecta) and Dytiscus maryinalis, with their wing-cases complete. Another example, killed in Deecmber, 1865, contained a perch seven and a half inches long, and various small fragments of the common reed, swallowed, no doubt, accidentally when killing the fish; and an extremely fine bird from Lutham, sold in our fishmarket in October, of the same year, weighed three pounds and a half, but hisd an eel twelve and a half inches long in its gullet. Mr. Lubbock mentions one which was shot with a water-rail whole in its stomach.

Under the old name of "bittour" this species is but once entered in the L'Estrange accounts, and is there specially mentioned as "kylled wt ye crosbowe," but there is no reference to it as affurding sport for the falconer in those days, although, according to Messi's. Brodrick and Salvin, it was a very favourite quarry for heronhawks when formerly abundant. As an article for the table it ranked with the heron in the olden time; indeed to my taste it is infinitely superior, having more of the true wild fowl flavour, and may, therefore, as Sir Thomas Browne hath it, "be esteemed the better" dish." In the Northumberland Household Book, "Bytters for my Lordes owne Mees at Principal Feestes" are "to be at xiid. a pece so they be good," being the same price as pheasants in those days; and at the Kertlinge festivities, in the Lord North accounts, five dozen and ten "Bitters" are entered at xviijli. vjs. viijd. A curious superstition with reference to this bird is thus mentioned by Willughby: "Its hind claw is remarkably long, and being a supposed preservative for the tecth, is some times set in silver and used as a tooth pick." Probably some of these natural curiosities may still exist in collections, although the virtue has gone out of them, and even their use become unknown. 
In the "Zoologist" for 1848 (p. 1965), the following passage occurs, amongst other ornithological records, by Messis. Gurney and Fisher:-_"An example of the American Bimtern (Botaurus lentiginosus), another interesting addition to the birds of Norfolk, has been lilled at Yarmouth; but not having seen the bird, we are not at present able to add anything to the bare mention of its occurrence." No doubt further enquiry at the time convinced the above authors that they had been misinformed; and as neither $\mathrm{Mr}$. Gurney nor $\mathrm{Mr}$. Fisher have now any recollection of the circumstance, this species holds no place in the Norfolk list.

\section{NYCTICORAX GARDENI* (Dickinson).}

\section{NIGHT-HERON.}

The carliest record I can find of the occurrence of this species in Norfolk is the statement in Sir W. Hooker's M.S., on the authority of the late Mr. Lilly Wigg, that, "Mr. Stagg shot one of these birds in Yarmouth about the year 1800." $\dagger$ We have next the

* As I have undertaken to follow the nomenclature of Yarrell, I am compelled to use this name, but it is now well known that the Ardea gardeni of Gmelin, was originally described from a young example of the American night-heron, and not the European representative species, which should stand as Nycticorax griseus (Linn.) It is not easy to ascertain who first confounded the two birds, but I imagine that Mr. Dickinson was the author of the mistake ("Trans. Linn. Soc." v., p. 276), and accordingly append his name to that of the bird, it being clearly understood that his Ardea gavdeni was not the same as A. gardeni (Gmelin.)

t Like the subsequent specimen in 1824, this bird was shot from a tree in a nursery garden, as stated by Messrs. Sheppard and Whitear, although the date is not given by them. 
evidence of Messrs. Paget, in 1831, that Mr. Yonell had known six or seven of them to have been killed in that locality, at different times, and in Mr. Hunt's List (1829), one is said to have been lilled at Docking, and another at Holkham; the latter, according to Messrs. Sheppard and Whitear, in 1819. Again, on the 21th of May, 1824, from a fruit tree, out of the north gates at Yarmouth, was shot the memorable specimen, which, first recorded by Mr. Youell, in the Limnean Society's Transactions (vol. xiv., p. 588), as the Cayeme night-heron (Ardea caycnnensis, Limn.), was, as such, included by Selby in his "Illustrations of British Ornithology."* This bird, however, which is now in Mr. Gurney's collection, and was purchased by him from the late Mrr. Thurtell, of Eaton, $\uparrow$ has been long since established as only a very fine adult specimen of $N$ ycticorax griseus, remarkable, as stated by $\mathrm{Mr}$. Youell, for having "six crest feathers of unequal length," and for the straightness and rigility of those feathers. I may here remark, however, that Dr. Henry Giglioli, in his "Notes on the birds observed at Pisa and its neighbourhood in 186-" (Ibis, 1865, p. 60), particularly mentions the variable number of the feathers in the occipital crest of the common night-heron, he having proctured a specimen with six, although he found three the more usual number. In the same winter of 1824, according to some notes recently supplied me by Mr. Rising, of Horsey, no less than three specimens of this heron were lilled on the North Denes, at Yarmouth, and another,

* So recorded also in Messrs. Paget's "Sketch," in Hunt's List and in the "Catalogue of British Birds," by Mr G. R. Gray, of the British Museum.

+ Mr. Thurtell bought this bird originally from Harvey, a Yarmouth bird preserver, and believing it to be a true Cayenne night-heron, refused $£ 30$ for it, offered him by the late $\mathrm{Mr}$. Lomive. 
in his own collection, was shot by his father about two hundred yards from the front of his residence, at Horsey, in April, 1827.

Since that time this species has become an extremely rare visitant to our coast, * the only recent instance, to my knowledge, being an immature bird, killed on the 8th of November, 1860, in the Caister marshes, near Yarmouth. This specimen, now in the collection of the Rev. C. J. Lucas, of Burgh, and sent to him, in the flesh, as an American bittern, resembles the second figure in Yarrell's wood-cut, having a triangular white patch, of more or less extent, at the tip of each feather. The feathers of the head and neck are also streaked with brown and white, each feather broadly edged with brown; the quill and centre of the web being white throughout. $t$ It is most probable that the specimen sold in Mr. Miller's collection, in 1853, was one of those mentioned by the Messrs. Paget as obtained in that neighbourhood, and Messrs. Sheppard and Whitear were informed by Mr. Hunt, of Norwich, that "one in his possession was shot in Suffolk, and was kept alive some time, being only slightly wounded."

* A male night-heron, in the Wisbech Museum, as I learn from Mr. T. W. Foster, was killed at South Brink, Wisbech, in July, 1849 .

+ In the "Ibis" for 1861, p. 53, in his notes "On the Ornithology of Hongkong, Macao, and Canton," my friend Mr. R. Swinhoe gives a most interesting description of the breeding habits of this species, from which it appears that "the immature plumage of the yearling undergoes little change until the second winter, or until the bird is over two years old." A bird in its first plumage was found sitting on a nest containing eggs, and tho testes of one dissected in its jurenile dress, plainly indicated its powers to breed at that age. 


\section{CIC ONIA ALBA, Bechstein.}

\section{WHITE STORK.}

"Ciconia raro huc advolat," wrote Sir Thomas Browne,* in a letter to Dr. Merrett, in 1668, quoting, indeed, the latter"s own words, $\nmid$ but adding, "I have seen two in a watery marsh, eight miles off [Norwich]; another shot, whose case is yet to be seen." Again, in his "Account of birds found in Norfolk," he speaks of having seen the "Ciconia, or Stork, in the fens, and some have been shot in the marshes between this [Norwich] and Yarmouth;" whilst Willughby, in his "Ornithology," expresses his obligation to his "honoured friend," Sir Thomas, for "a picture of one of these birds, taken on the coast of Norfolk, drawn by the life, with a short description of it," which specimen, in confinement, $\ddagger$ "readily eat frogs and land-snails, but refused toads." Turner years before (1544) had stated "Ciconia, ut Germanis auis est notissima, ita Britannis meis plerisque omnibus tam ignota est, quàm quæ omnium ignotissima. Nec mirum, quum nusquam in insula nostra nisi captiua Ciconia uideatur ;" and Jonston, whose work\| bears a figure of this bird on its frontis-

* See Wilkin's Ed. of Sir Thomas Browne's works, vol. i., p. 398.

† "Pinax Rerum Naturalium Britannicarum." Londini : MDCLXVII., p. 181.

‡ The following occurs in the "Extracts from Sir T. Browne's Common Place Books" (vol. iv., p. 399), amongst other " empirical" remedies for gout suggested for trial by the learned doctor to some querulous friend "unsatisfied with the many rational medicines." "Since you find no benefit in the noble plasters of the Duke of Wirtemberg, of King James, and of Charles the Fifth, try the empl. ciconice made up of stercus ciconice." We are not told, however, whether the patient was actually supplied with this precious ointment, from the captire stork in Sir Thomas's garden.

|| "Historiæ Naturalis de Auibvs Libri vi." Francofurti ad Mrnum : M.D.C.L.

$2 \mathrm{~A}$ 
piece, with the motto "Pietas contenta lucratur," bore witness to the same, saying that storks "in Britannia ignotas esse." Ray, too, in his "Synopsis" (1713), asserts that the species "In littoribus nostris interdum sed rariùs cernitur; apud nos non nidificat" (p. 97). Still, notwithstanding these old records, so fortunately preserved to us, I see no reason to suppose that, as an accidental visitant, the stork was less frequently met with on our coast, at that time, than it is now, although fewer examples fell victims to their too confiding nature, and many, most probably, passed wholly unnoticed. It must, however, be always borne in mind that the stork was but a stranger in the land, and not an inhabitant as were the crane and the spoonbill.*

Going back to the commencement of the present century, we have ample evidence of its appearance in this county, year after year, on its migratory course, and more recent observations entirely confirm the statement of Messrs. Gurney and Fisher, in 1846, that, "one or two of these birds are generally killed in Norfolk every year, generally during the spring months, and in the vicinity of the eastern coast." Now and then, however, a specimen is met with far inland, either storm-driven, or, more often, seeking in vain to escape persecution.

In Sir William Hooker's MS. I find the following important notes, which are, in many points, confirmed by the Messrs. Paget:- "A stork seen about Yarmouth by $M r$. Penrice and $M x$. Bonfellow in the autumn of 1810; a pair seen at Burgh Castle during the months of May and June, 1817, and at length shot in the beginning

* The necessity of this remark will be seen, when we turn to the last edition of Mr. Hewitson's well-known work (ii., p. 309), wherein, after quoting a passage from Erelyn's "Diary," he puts upon it a meaning it does not actually bear; for, if taken according to Mr. Hewitson's sense, it would equally imply that eagles bred in Norfolk, which there is no reason to believo. 
of July; another before that time shot at Caister,** and one killed in Norfolk, May 6th, 1818, now in the possession of Mr. J. Hunt, of Norwich." $\dagger$ Of more recent date, there is a record in Mr. Lombe's notes, of one killed near Holt, in 1836; Mr. Lubbock mentions one killed at Wretham; in 1838, and an adult bird in the Norwich Museum (No. 211a) was shot near Yarmouth, in 1842. Of this latter specimen, I find the following interesting" description in the "Zoologist" for 1843, (p. 182), from the pen of Mr. W. R. Fisher (then residing at Yarmouth):- "As I was walking on the beach, on the morning of the 10th of May last, I observed a bird of this species coming over from seawards. When it first came over the shore, it was flying so low that I could plainly distinguish its long legs stretched out behind, like those of the heron, the black bar across the wings, formed by the quill feathers and wing coverts, contrasting strongly with the pure white of the rest of the plumage. I watched it for some minutes, as after taking two or three turns over the houses, it slowly soared to an immense height, and then went steadily off in a south-westerly direction. It was shot the next day about six miles from Yarmouth." At Halvergate, as $\cdot \mathbf{M r}$. Fisher subsequently informed $\mathrm{Mr}$. Yarrell. In Mr. Dowell's notes I find two records of storks observed at Salthouse, one purchased by Mr. J. H. Gurney several years ago, but not now in his collection (though he still possesses a more recent specimen killed on Breydon); and another seen in the Cley

* These are probably the same birds thus noticed by Messirs. Sheppard and Whitear in 1824. "A few years since a pair of white storks were seen at Gorleston, and one of them was killed. Another pair was observed at Acle in the month of June, 1817 ; and about the same time a female of this species was killed near Burgh Castle; and another in the month of November following."

+ Probably tho ono recorded in his List as killed at Cautley.

2 A 2 
marshes, in the summer of 1849, within shot of the Salthouse bank.

On the 7th of June, 1848, an adult female, now in the possession of the Rev. H. T. Frere, of Burston, was shot on Breydon, as noticed by Messrs. Gurney and Fisher in the "Zoologist" (p. 2291). In 1852 Mr. L. H. Irby recorded in the same journal (p. 3476) the occurrence of an adult male on Breydon, about the 15th of March (now in Major Irby's possession); and in February of the same year an immature specimen also, killed near Yarmouth, was sent up to Norwich for preservation. This bird had evidently received a previous wound from the effects of which it had been gradually wasting, and was thus happily destroyed.* A second example in the Norwich Museum (No. 211), in adult plumage, was procured at Brooke, near Norwich, in August, 1853.

On the 3rd of October, 1855, whilst travelling by an early train on the Great Eastern Railway, I saw one of these birds in a low meadow, at Lakenham, near Norwich, not far from the line, and, as long as I could observe it, perfectly undisturbed by the noise of the passing carriages. It was standing apparently in a little watercourse, as I could see only part of its legs, with its head and neck thrown back, and its red beak resting on its breast in the most perfect repose; whilst the marked contrast of the black wing feathers to the pure white of the rest of the plumage was strikingly visible in the bright morning sun.

On the 14th of September, 1856, a very fine stork was seen on the farm of Mr. Sewell, of North Pickenham, near Swaffham, from whence it flew into some low grounds belonging to Mr. R. Hall Say. Mr. Say's

* These are the tro specimens recorded by mistake in Morris's "British Birds" (จol. iv., p. 152), as killed in 1851. 
keeper went in pursuit and succeeded in shooting it in a long plantation belonging to that gentleman.

In 1858 a fine specimen now in the collection of the Rev. C. J. Lucas, and formerly in that of Mr. A. F. Sealy, was shot at Yarmouth, and was purchased by the latter gentleman in the flesh.

On the 29th of November, 1860, an adult female was killed at Hickling, which, like the one in 1852, had suffered greatly from a previous wound, as shown by its soiled plumage and poor condition.

About the 17th of May, 1861, an adult female was shot on the late Mr. Cator's estate, at Woodbastwick, and is still, I believe, preserved at the hall. This bird contained an egg quite ready for exclusion, which was only slightly cracked on one side by the fall of the bird.

And last in the list to the present time is an adult bird, in Mr. Overend's collection at Yarmouth, which, as stated in the "Field" (vol. xxv., p. 384), was killed on the 24th of May, 1865, in some marshes at Oby, about seven miles from the coast.

A glance at the dates of these specimens, where such records exist, shows not only the singular regularity with which the stork appears on our coast, but, as before stated, that by far the larger number are met with during the spring and summer; and, it is difficult to account for the fact of their never having bred with us, even in former times, when, as we know from the evidence already cited, they were but rarely killed. The pair killed in the Burgh marshes in 1817, were certainly reluctant enough to quit our shores, having been observed through May and June, and not shot till July; and the Woodbastwick bird, found heavy with egg on the 17th of May, 1861, had previously, no doubt, been separated from its mate. As a species, however, proverbial for the regularity of their migra- 
tory movements, ${ }^{*}$ we can scarcely wonder if slightly deviating from their ordinary course, stragglers should alight, year after year, on our eastern coast, so similar in many respects to their summer haunts on the opposite shores of Holland. But here, unhappily, instead of wooden boxes being erected in our towns and villages for their nesting accommodation, the only box provided is the birdstuffer's case, wherein the victim of misplaced confidence inevitably finds its last home.

\section{CICONIA NIGRA (Linnæus).}

\section{BLACK STORK.}

If the American bittern at present holds no place in our Norfolk list, I am able to include for the first time a not less interesting species in the Black Stork, an extremely rare and accidental visitant to this country. $\dagger$ On the 20th of May, 1867, I received a

* "Yea, the stork in the heavens knoweth her appointed times; and the turtle and the crane and the swallow observe the time of their coming."-Jeremiah viii., 7.

+ Yarrell enumerates only four specimens killed in any part of Great Britain-namely, Colonel Montagu's bird on West Sedge Moor, Somersetshire, May 13th, 1814; one on the Tamar, in Devonshire, November, 1831; one at Otley, near Ipswich, Suffolk, October, 1832 ; and one on the south side of Poole harbour, November 22nd, 1839. In addition to these Mr. A. Newton also informs me that Mr. Thornhill, of Riddlesworth, possesses a very fine specimen, which he obtained in the flesh more than twenty years since, of a labourer who had just shot it on some property of his own in Romney Marsh; and in Mr. J. H. Guruey's collection is a specimen purchased by him at Poole some years ago, which has a memorandum inside the case in which it was then mounted, to the effect that it had been killed at Poole in 1819 ; just ten years later than the one, before mentioned, from the same locality. 
letter from Mr. Anthony Hamond, jun., informing me that a fine black stork had been shot by one of the gamekeepers in some meadows on the banks of the river Nar, at Westacre, about half-past four in the morning of the 19th.* The bird, it seems, had been observed about the same locality on several occasions for more than a week, but had hitherto kept well out of shot, and only on the day previous to its death, Mr. Hamond and myself had been watching a pair of gadwalls in the Nar, scarcely a quarter of a mile from the spot where the stork was killed. It proved on dissection to be an adult female, weighing over seven pounds, and measured, I am told, six feet two inches from tip to tip of wings. Its plumage showed no signs of having been in confinement, and, owing to its extreme shyness, it was even at last obtained with much difficulty. This noble specimen now forms part of the fine collection of birds at Westacre High-house.

Although the first time that this species has been known to be killed in this county, it is probable that others may have visited our coast, and either escaped injury or passed wholly unnoticed. Thus, in Mr. Joseph Clarke's MS. notes on rare birds at Yarmouth and other parts of the county, I find the following under the head of Ciconia nigra, "Three were followed in Norfolk for some days in the year 1823; and in 1832 one was killed in Suffolk, at Grundisburgh, and was in the possession of a surgeon, a Mr. Ditton, of that place." The latter is no doubt the bird mentioned by Yarrell as killed at Otley, near Ipswich.

* This bird was recorded at the time in the "Ibis," 1867, p. 382; "Zoologist," s. s., p. 872 ; and in "Land and Water," vol. iv., p. 26. 


\section{PLATALEA LEUCORODIA, Linnæus.}

\section{WHITE SPOONBILL.}

But for the most trustworthy records of Sir Thomas Browne, it would scarcely have been credited at the present time, that this remarkable species was formerly a resident in East Anglia. This important fact, however, is preserved to us in the following passage from Sir Thomas' notes on the "Birds of Norfolk," "The Platea or Shovelard,* which build upon the tops of high trees. They formerly built in the hernery at Claxtont and Reedham; now at Trimley, in Suffolk. They come in March, and are shot by fowlers, not for their meat, but for the handsomeness of the same; remarkable in their white colour, copped crown, and spoon or spatule like bill." From so minute a description of the species, there can be no doubt as to its identity, but even at that time (1688) it seems, through the persecution of the fowlers, they had ceased to breed in Norfolk, though still found at Trimley, in Suffolk, the "handsomeness" of their plumage rendering their destruction as certain as in more modern times. Pennant, whose most elaborate account of the spoonbill,

* There is no doubt, as suggested by Mr. Lubbock, that the terms shovelard, sholarde, and shoveller, met with in the "Household Books" and other early records of birds procured for culinary purposes, referred to this species and not, as supposed by some, to the shoveller duck (Anas clypeata), even though the latter is specially noticed by Sir Thomas Browne as "Anas platyrhinchus, a remarkably broad-billed duck." In the Northumberland "Household Book" we find the following entry:- "Sholardes to be hadde for my Lordes owne Mees at Pryncypall Feestes, and to be at vid. a pece," being half the then price of bitterns and curlews.

+ Seven and a-half miles from Norwich, near Buckenham Ferry, on the river Yare; and Reedham, nine miles from Yarmouth on the same stream. 
was taken from a freshly killed specimen, sent him from Yarmouth by the late Mr. Joseph Sparshall, states in the "Appendix" to his "British Zoology" that "a flock of these birds migrated into the marshes, near Yarmouth, in Norfolk, in April, 1774," but since that time, although an annual visitant to our shores, on its migratory passage, it has appeared only in pairs, or at most three or four at one time. According to Messrs. Sheppard and Whitear, "a pair were seen at Cromer, in June, 1818; and one was killed at Yarmouth in the month of May of the same year." In 1829, Mr. Hunt remarks in his list, "In the course of the last five or six years, seven or eight of these birds have been killed at Caister and Burgh, in the neighbourhood of Yarmouth, one of which is in the Norwich Museum* and another in the possession of Mr. J. J. Gurney." Mr. Selby, also, in his "British Ornithology," states that when in London, in May, 1830, he obtained a male and female in fine adult plumage from Norfolk, this recently killed male being the one represented of the size of life in his work.

In Sir William Hooker's MS. one is said to have been taken alive on Salthouse broad, May 21st, 1831; three more on Breydon, in June, 1834; and an adult bird in the Norwich Museum, $\dagger$ is stated to have been killed at Salthouse, in 1838. Mr. J. H. Gurney's collection contains three spoonbills in one case, two of which, in immature plumage, were shot together near Yarmouth; and the third, an adult male, was purchased in the Norwich Market prior to 1846, being the one referred to by Messrs. Gurney and Fisher in the

* Probably the specimen (No. 213b) still preserved, as a skeleton, and marked "Adult, Norfolk."

† No. 213 in the Museum collection, marked "MIale adult, September, 1838." 
"Zoologist" (p. 1322) as falling short in all its measurements of the usual size of the species, attributable, no doubt, to "an old fracture of the thigh bone, which was discovered when the bird was dissected for preservation."

Of more recent instances, the following comprise, I have no doubt, a large proportion of the specimens either observed or procured in this county.

1845. Two old males killed at Salthouse, as recorded by $\mathrm{Mr}$. Dowell.

1847. May 2nd. A fine old male killed on the Bure, near Yarmouth; another, also a male, but in immature plumage, was shot on the 19th, at Salthouse ("Zoologist," p. 1785). In Mr. Dowell's notes two are also stated to have frequented the Blakeney coast for some weeks towards the end of August; and on October 27th, a fine female, in Mr. Dowell's possession, was killed at Salthouse, having been previously seen for some days about Blakeney harbour.

1848. February 11th. Mr. Dowell records one as taken in the Langham decoy; and on the 15th of November a female was brought to him in the flesh, having been seen in company with another at Salthouse. It had been previously wounded in the leg, and was then too much injured for preservation. "This bird is said to have resorted, at intervals, to a marsh at that place for nearly a month previous to its capture." ("Zoologist," p. 1966).

1849. June. A male killed near Yarmouth, as recorded by Mr. Gurney in the "Zoologist" (p. 2499); and another at Salthouse in the same year, in the Dennis collection, at Bury.

1850. June 18th. An adult male at Breydon, also in the Bury Museum.

1852. Mr. Dowell informs me that in this year throughout March and part of April a pair of spoon- 
bills frequented the lake at Holkham, and being unmolested, Lord Leicester on one occasion walked close up to them.

1853-4. Somewhere about this date a specimen in Mr. Newcome's collection, at Feltwell, was procured in Hockwold fen.

1855. May 14th. A fine old male killed at Stiffkey, near Wells.

1859. May 4th. A male in very perfect plumage shot at Hickling. The long crest of this bird was buffywhite and a rich broad band of buff-colour extended across the breast and formed a collar, as it were, round the lower part of the neck, which was deepest in colour near the points of the wings. The under parts were also faintly marked with buff on the tips of the feathers. I saw this specimen in the flesh, and was struck with the richness of its colouring, but on seeing it again a week or so later, the buff tints had almost faded away, and I doubt not after a time would be scarcely perceptible.

1860. July 6th. One shot on Breydon; sex not noted.

1862. May. A female in Captain Longe's collection, shot on Breydon; and a male from the same locality, in that month, was sent up to Leadenhall Market with greenshanks and turnstones.

1863. May 15th. A young female in pure white plumage and scarcely any crest, was shot at Hickling.

Early in the same month two or three were also seen on Breydon; and a magnificent pair were killed at one shot between Lowestoft and Southwold, in Suffolk, * on the 1st of May, which were preserved by

* During the last four or five years Mr. Fenwick Hele has recorded the occurrence of this species almost every spring at Aldeburgh and Thorpe Mere, on the Suffolk coast. Vide "Field" (June 25th, 1864, p. 413; July 28th, 1866, p. 81; and July 13th, 1867, p. 31). 
the late John Sayer, of Norwich, for Mr. Maurice Johnson, of Benacre Hall.

1864. October 25th. An immature specimen, killed at Hickling, was presented to the Norwich Museum (No. 213a). The sex of this bird was not noted at the time, but the irides were light grey, not red as in adult birds.

About the same date the Rev. C. J. Lucas, when snipe shooting at Burgh, fired at a spoonbill, which flew wounded in the direction of Yarmouth. On sending to Yarmouth the same evening, he learnt that a spoonbill had just been shot in that neighbourhood, most probably the same bird, which he purchased for his collection, an immature female.

1865. May 23rd. A pair shot on Breydon, which are now in Mr. J. Tomlinson's collection at Yarmouth.

A fine bird in the possession of Mr. H. M. Upcher, of Sherringham, was also killed during the spring of this year at Sandringham, near Lynn.

1866. May 2nd. A fine old male which had been seen on Breydon for nearly a fortnight, was shot, and one or two others were seen about the same time. This bird, in the collection of the Rev. C. J. Lucas, of Burgh, had a rich band of buff-colour on the breast, but the crest was not much developed; irides carminered. The throat contained three or four three-spined sticklebacks, ${ }^{*}$ quite perfect, and the stomach was filled with the remains of others mixed with sand and silt from its feeding grounds. A bird recorded by Messrs. Sheppard and Whitear had the remains of shrimps in its stomach.

* These were forwarded by Mr. T. E. Gunn, of this city, to Dr. Gray, of the British Museum, who identified them as the rare smooth tailed species, or variety, (Gasterosteus leiurus). Seo "Zoologist" for 1866, p. 348. 
May 20th. About this date a single individual was observed for some days on Hickling broad, and was probably the bird killed on the 10th of June, at the same place, which came into the possession of $\mathrm{Mr}$. F. Norgate, of Sparham, and proved to be a young male.

1867. Three or four were seen in the spring about Burgh-flats, but none shot that I could ascertain.

1868. May 4th. Two males shot at Yarmouth; one weighed four pounds, and was darker in plumage than the other, not having perfected its moult, but it had the longer crest of the two. The other, now in my collection, weighed three pounds and a-half. In both the eyes were carmine-red, and they had a yellowish tinge across the breast. In one the stomach was empty with the exception of soft silty matter, the other was filled with the remains of shrimps, and scales of small fish and sand. A much older bird in Mr. Overend's collection, at Yarmouth, was killed on Breydon about the same time.

From an examination of the above list of specimens it will be seen that the spoonbill is chiefly a spring and summer visitant to this county, since of those, of which the date of occurrence is known, only eight have appeared towards the latter part of the year, two in August, one in September, three in October, and two in November.* The remainder in February (one), March and April (two), May (eighteen), June (ten), and one in July, whilst the large flock at Yarmouth, in 1774, is said to have arrived in April. The majority

* By Messrs. Sheppard and Whitear this species is said to have appeared near Yarmouth, "generally during the winter season;" and Colonel Montagu speaks of the occasional appearance of the spoonbill in winter, in the south of England, and in his supple. ment records the occurrence of a young bird, near King's Bridge, South Devon, in November, 1804. 
of specimens obtained are decidedly in immature plumage.

Unlike the stork the spoonbill, though similarly persecuted, does not often betake itself far inland, relying mainly for subsistence on the daily renewed feast, afforded by the ebb and flow of our tidal waters; and hence the large proportion of them that are seen and procured on Breydon. The Salthouse marshes, until their drainage and embankment in 1851, were also a most favourite resort of the spoonbill, as well as of the avocet, a somewhat similar feeder, * but this spot is no longer adapted to their habits. An occasional straggler or two may be seen, however, along the flat shores of the wash; and Hickling, near Yarmouth, appears to be the only broad that has special attractions for this singular species.

* In the "Zoologist" for 1843 (pp. 226, 227), in his "Notes on the Birds of Sussex," Mr. A. E. Knox describes the mode of feeding of the spoonbill from certain facts supplied him by Mr. A. T. Dodd, of Chichester. The latter gentleman, it appears, had received a specimen recently killed in that neighbourhood from "an intelligent person of whose accuracy of observation he entertained no doubt," and the mode adopted by the bird was described as that of "ploughing the soft sand or mud from side to side with its bill, to the depth of about a quarter of an inch, by which he supposed it collected small marine insects and worms, while it continued to work the bill all the time, precisely like a duck." The following note, also, on this subject, from observations made in Hungary by Major Thomas Walker, of Wexford, is given by Thompson in his "Birds of Ireland" (vol. ii., p. 180). "The motions of the spoonbill are singular, when a number are standing in a line on the edge of a stream, they keep streaking the bill sideways through the water, and the movement is simultaneous; all the bills being directed up the stream at once, and all down it at the same time." 


\section{IBIS FALCINELLUS (Gmel.)}

\section{GLOSSY IBIS.}

Mr. Lubbock, in 1845, thus wrote of this rare species, "Fifty years back it was seen often enough to be known to gumners and fishermen as the black curlew, ${ }^{*}$ " but now a straggler or two at long and uncertain intervals is an important event in local ornitlology, and the bird itself, if procured, a coveted possession by all local collectors. In the various stages of plumage, however, to which the terms glossy, bay, and green have been applied by authors, this Tbis has been killed in Norfolk in many well-authenticated instances, the first of which I can find any exact record being the bird stated by Messrs. Sheppard and Whitear to have been seen by them, and "shot in the winter of 1818, in the marshes on the western coast of Norfolk, near Lynn;" adding, moreover, " that it did not appear to have attained its full plumage, from the circumstance of its having four transverse bars of white on its throat." From the same authors we also learn that " in the month of May, 1822, three birds of this species were seen at Hockwold [fen], in Norfolk." Two of them were killed, and are in the possession of the Rev. Henry Tilney, of that place." One of these, in adult plumage, is now in $\mathrm{Mr}$. Newcome's collection, at Feltwell, from whom I recently ascertained that the other (both having been shot by Mr. Tilney), was, unfortunately, not preserved. The last two are also noticed in Mr. Lombe's MS. notes, as killed in June, not May, which is, I believe, correct. Next in point of date, are the pair recorded by the Messrs. Paget as

* Under this name it is possibly the species meant in the old adage-

"The curlew be she white or black,

Carries twelve-pence on her back." 
"shot at the mouth of the Norwich river, September 13th, 1824," "* which came into the possession of Mr. J. J. Gurney, of Earlham; $\dagger$ and had "four more in company with them." These, in Sir W. Hooker's MS., are said to have been male and female, the former weighing one pound and a-half, the latter one pound two ounces. The length of the male from the tip of the beak to the end of the toes was thirty inches, of the female twenty-six inches, and from tip to tip of wings, the former measured forty inches, and the bill was five inches long.

In January, 1825, according to Mr. Lombe's MS. notes, two more, male and female, were killed at Yarmouth, and may possibly be the pair which are still preserved in his fine collection at Wymondham.

In $M r$. Hunt's List, published in 1829, a single specimen, killed near Cromer, in Mr. Norman's collection, is said to have been "sold to him under the name. of the "black curlew," which fully corroborates Mr. Lubbock's statement as to the name commonly applied to this species.

Again, in October, 1833, according to Mr. Lombe, a single specimen was killed near Norwich, which is also mentioned in Mr. Joseph Clarke's MS. notes, the latter, moreover, stating that the two which formed part of the late Mr. Miller's Yarmouth collection were procured near that town in 1832. Strangely enough from that time, until the year 1850, I know of no instance of this species appearing on our eastern coast, but on the 27 th of May of that year, as recorded by Mr. J. H. Gurney in

* No doubt, the pair recorded by Mr. Youell in the "Linnean Transactions" ( October, 1824.

+ Now in Mr. J. H. Gurney's collection.

‡ I cannot trace these birds which were sold with the rest of Mr. Miller's collection in 1853. 
the "Zoologist" (p. 2879), "a very beautiful adult specimen was shot on Blundeston marsh, near Lowestoft. The bird was a female, but the ova were not larger than small peas."

Again after an interval of just eight years, I ascertained through Mr. Rising, of Horsey, that an ibis had been seen, but not procured, in the vicinity of Yarmouth, early in the month of January, 1868; and on the 13th of September of that year, the last that has been recognised in this county was killed at Stalham. This bird, which is now in the possession of Mr. Silcock of that place, proved to be a female, apparently in the plumage to which the term "glossy" has been usually applied. The head and upper parts of the neck are light reddish-brown streaked with white, some of the feathers being white at the tips, and others white only along the outer edge of the web on either side with the tips brown. The lower part of breast, and under plumage generally, is reddish-brown, with green and purple feathers intermixed, the latter chiefly on the flanks. The back is glossed with purple and green reflections. Scapulars, wing-coverts, and quill-feathers, bright glossy-green, having a bronzed hue, the latter deepest in colour, as also the tail-feathers. The primaries darker in colour than the secondaries. Weight one pound six ounces; total length twentyfive and a-half inches; extent of wings forty-two and a-half inches; from the carpal joint to the end of longest quill (second) twelve inches; bill, following the curve of upper mandible, five and three-quarter inches; tail four and a-half inches; bare portion of tibia, two and three-quarter inches; tarsus four and a-half inches; middle toe and claw three inches and three-eighths; hind toe and claw one inch and three-quarters; inner toe two inches and three-quarters; outer toe two inches and seven-eighths. The stomach was empty with the exception of one minute shell of the periwinkle. 
As shown by the measurements and descriptions given by Montagu in his "Supplement" these birds vary much both in size and colouring, the females being somewhat smaller than the males, and in their immature stages showing more white about the head and neck.

\section{NUIENIUS ARQUATA (Linnæus).}

\section{COMMON CURLEW.}

The Curlew is another of those grallatorial species which, although observed on our coast during every month of the year, has never been known to nest in this county. Further north* it breeds in April and May, but throughout the latter month I have remarked them at Hunstanton, and have heard their loud whistle in June, when out at sea, and seen stragglers at the same date both at Cromer and Salthouse. Yet, though such may be considered as exceptional cases, the bulk of those which annually visit us in autumn and winter are absent only for a very short period. By the 1st of July Mr. Dowell has known them arrive at Blakeney in some numbers, and has seen them there in flocks of forty or fifty by the end of

* In Mr. A. G. More's paper "on the distribution of Birds in Great Britain during the nesting season" ("Ibis," 1865, p. 434), the curlew is described as "rare in the south during summer, though a few pairs are recorded as breeding in Cornwall and Devonshire." Its breeding in Dorset and Wiltshire is considered doubtful, the stone curlew (EEdionemus crepitans) being probably mistaken for it in those counties, but "further north there are one or two breeding stations in Shropshire, and Mrr. O. Salvin finds its nest in Derbyshire." We also learn from the same anthority that "the curlew breeds in North and South Wales, and from Yorkshire northwards, extending as far north as the Shetland Islands." 
that month. Between the 25th and 30th of July, I have also watched small parties flying low over the sea at Cromer, keeping steadily on in a south-westerly direction, but rarely exceeding six in number, as if young and old together. Later still in the autumn, their migratory movements are evidenced by their cries, as, (attendant on, or mingling with, large flocks of golden and green plover,* redshanks, \&e.), they pass over our towns and cities by night, attracted and bewildered by the glare of the lamps ; chance stragglers, also, when thus calling to their mates, will frequently answer to a whistle in imitation of their notes. In like manner attracted by our light-houses and light-ships on the coast, they are heard, at times, flying round and round for hours, but as far as I can ascertain are never known to "strike the glasses," as is the case with many other species.t In winter during hard weather their numbers are greatly increased from the north, most of which continue their course southward should the frost continue, but even in the sharpest weather I have seen them on Breydon in considerable numbers, and the gunners are not slow to take advantage of their miserable plight when tamed by cold and hunger. As a rule, however, the curlew is a most difficult species to approach, especially when feeding in large bodies, and their loud warning cries alarm many other birds that might otherwise afford a shot. Even in a punt, as Mr. Dowell remarks, it is not easy to get within range of them, "as they usually sit some short way from the water, and their height enables them to

* See antea, pp. 71-76.

+ This fact was particularly mentioned to me by a rery intelligent watchman, at Lowestoft High-light, who had beeu formerly at Orford-ness, and who, from a personal interest in the subject, afforded me much information.

2 с 2 
see into the boat." Single birds may be occasionally decoyed within shot of a bank or other ambush, by skillful whistling; ; but in companies, as Mr. Lubbock states, "they are deaf to the call."

Though always plentiful on the Breydon muds, this species is met with in still larger numbers at Blakeney, and thence, westward, along the flat shores of the Wash to Lynn may be termed their chief stronghold in Norfolk. In the spring of 1863, I found them very plentiful at Hunstanton, though almost unapproachable on those level sands, but their daily visits to the mussel-scalps, with that marvellous punctuality observable in such species as regularly frequent the sea coast, proved a constant source of amusement. Scarcely was the thin black line visible above the waves, which marked the outline of a large submerged musselbed, than curlews and sea-gulls appeared in the distance, the former in small detachments and in Indian file, slowly flapping over the waters to their expected feast, which their long legs and bills enabled them to commence at once, not waiting, like the hovering sea-gulls for a drier surface. First to arrive they were also the last of their kind to quit their feeding grounds, seeking the highest spots as the tide rose, and taking wing only when the "scalps" were barely

* Mr. W. H. Power, in the "Zoologist" for 1866 (p. 124), gives a singular account of the means by which the fishermen and "muddiggers," at Rainham, in Kent, decoy curlew within shot. A trained dog, as much like a fox as possible, is employed to attract the birds, whilst the man hides in a "dyke," and when the birds attack and chase him, the dog gradually approaches his master's hiding place, when sometimes two or three shots are obtained (provided the gunner keeps concealed), so engrossed are the curlews with the actions of the dog; but both this plan and the "curlew whistle" fail to attract them in parties of more than four or five. 
visible when, uttering their loud cry of "cour-lieu," "cour-lieu"* —a sound, however wild and shrill, not less grateful to the ear on a bleak range of ooze or shingle, than on some scarcely less desolate moorlandthey would betake themselves once more to their inland haunt.

The great difference of size in individuals of this species must have attracted the notice of every naturalist and sportsman, but whether a matter of sex or of age, appears still a matter of doubt. $\dagger$ I am sorry that I cannot here say anything positive on this point, not having had the opportunity of dissecting a sufficient number of large and small specimens, $\ddagger$ but supposing the largest to be really females, the males look more like whimbrels in comparison with their more than "better halves." Mr. Lubbock, in reference to this point, remarks that these large birds, from their

* Mr. Harting, in his "Birds of Middlesex," gives two other notes from his observation of this species, "wha-up" and in the spring "whee-ou, whee-ou," the latter I have frequently distinguished.

† In Meyer's "British Birds," (vol. 4, p. 196) the female is thus described "Larger than the male, her colouring is more tinged with ash, and her legs brown. The young are smaller according to age, and their beaks also shorter and by far less curved." The legs of the adult male he describes as "bluish-ash colour." Degland also, in his "Ornithologie Europienne" ( very similar statement.

+ A fine bird in my own collection (sex not known) has the bill five inches and five-eighths, total length from tip of beak to end of tail feathers twenty-five inches (when stuffed); tarsus three inches and five-eighths; and weighed two pounds three ounces and a-half. Another specimen, ascertained by dissection to be a female, has the bill five inches and four-eighths; total length from beak to tail twenty-four inches and three-eighths; tarsus three inches and four-eighths. The stomach contained only portions of the claws of minute crustacea. 
appearance in the marshes about harrest time, are known to the gunners as the "great harvest curlews," and suggests that they are "probably old females collected together after the breeding season." These he describes as "the most clamorous," and, when flying singly, as answering most readily to the whistle. On the other hand, both Folkard and my friend $\mathrm{Mr}$. Harting, are inclined to believe that the difference in size is merely a matter of age, but having recently ascertained beyond a doubt that the very marked difference in size in specimens of the bar-tailed godwit, is purely sexual (the females being the largest), I cannot help thinking that future observations will prove that the same rule applies to the greater and lesser curlews.

Some thirty years ago, as Mr. Thomas Edwards informs me, these "great harvest curlews" used regularly to come up from the sea in August, to feed on the "Ollands," at Hempstead, near Holt, numbering at times some thirty or forty in a "herd," when many of them were shot; but according to Folkard those killed "far inland, in ploughed fields and fresh water meadows, are not so palatable" as the birds shot on the ooze or in salt marshes; and Mr. Lubbock speaks of their excellence when procured in the marshes, as compared with their rank flavour after feeding on the sea-shore. Of their estimation in former times as a delicacy for the table we have ample testimony. In the L'Estrange "Household Book" we find no less than seven entries relating to this species; in one instance a pair are received as a present; in another, two are received of "gyste" (in lieu of rent.) Single curlews are purchased at from four pence to five pence each, and on one occasion three fetched, in Snettisham Market, two shillings (the then price of a fat sheep), whilst at the same time three woodcocks were procured for sixpence. The 
most startling fact, however, for modern housekeepers appears as follows, in the year 1519:- "Itm pd for a goos vd., a Pygge iiijd., ij Curlews xijd."

In the Lord North Accounts we also read, "Kyrlewes to be hadde for my Lordes owne Mees at Pryncipall Feestes, and to be at xijd. a pece."

A curlew, with white primary quills, was seen by Mr. Dowell, at Blakeney, in January, 1854.

\section{NUMENIUS PHEOPUS (Linnæus.)}

\section{WHIMBREL.}

The Whimbrel visits us regularly in spring and autumn, on its passage to and from its breeding grounds, and though a few may be seen occasionally in March and April, the appearance of the main body in May, on the Breydon and Blakeney muds, is so invariable that this species is always spoken of as the "May bird" by the gunners in both localities. Their numbers, as with all migratory shore-birds, vary much in different seasons, but at times they are very plentiful,* as was particularly the case in the spring of 1863 . Of these the chief portion pass on to the northward after a few days, but small parties may be seen on different parts of the coast up to the middle of June, and even as late as July. At Hunstanton in 1863, I found one or two small flocks frequenting the mussel-scalps up to the second week in June; and Mr. Dowell has observed

* In the "Zoologist" for 1867 (p. 293), Mr. Cordeaux states that a flock of at least two hundred appeared in the Humber district, about the 3rd of May; and on the 13th of May, 1868 ("Zoologist," p. 1283), he counted up to sixty-one, in one flock; and saw another containing not less than double that number. 
them at Blakeney in two or three different seasons, between the 25th and 30th of July, "not paired off, but keeping together in 'herds' of from eight to ten," most probably birds which would neither breed here nor elsewhere during that summer. By the end of August or beginning of September, old and young together, have again commenced their southward journey, but the numbers then seen are but few in comparison with the spring flight.* In Mr. Dowell's notes I find no record of this bird having been observed by him at Blakeney later than the first week in October; and Mr. F. Frere describes them as always scarce in autumn on Breydon, and rarely, if ever, seen during the winter months.

As in the case of the curlew, the north-western portion of our coast from Blakeney to Lynn, with its flat sandy shores and small tidal channels, has most attractions for the whimbrel, although Breydon for similar reasons is a favourite resort, and examples have been killed occasionally in the south-western district about Feltwell and Hockwold. Mr. Lubbock speaks of this species as having been occasionally very numerous at Horsey, visiting the marshes in considerable flocks in April and May; and in describing the habits of the birds, he says "they are far more easy of access than the curlews, and when disturbed make shorter flights, removing only from one marsh to another, instead of rising high in the air and forsaking the district altogether as the curlew generally does. They have a clattering confused cry in flight, which

* Mr. Cordeaux ("Zoologist," 1866, p. 294) remarks the same thing in Lincolnshire, where, in August and September, the whimbrel are seen in small parties passing over head at a considerable height, constantly repeating their call note, and flying in a south or south-westerly direction. 
baffles any imitation by the human voice." This cry, however, according to Messrs. Sheppard and Whitear, resembles the sounds "Weddy, tetty, tetty, tetty, tet," quickly repeated. Mr. Cordeaux also ("Zoologist," s. s., p. 1283) states, from his observations in Lincolnshire, that they are "far more a land bird than the curlew, feeding almost exclusively in our marshes, retiring occasionally to the flats to rest and bathe;" being particularly fond of washing and splashing the water over their plumage with their wings.

Whimbrels as well as curlews differ much in size, which, if a sexual distinction in the one, is the same no doubt, in both, and from the general similarity of the two species in other respects the whimbrel is provincially known by the name of the "half-curlew."

Mr. Fenwick Hele, of Aldeburgh, who found the whimbrel very abundant on that part of the Suffoll coast in May, 1867 ("Field," vol. xxix., p. 389), states that he observed amongst them a light cream-coloured specimen.

In my account of the common house-sparrow, in the first volume of this work, I ventured to assert that the late Bishop Stanley, in his "Familiar History of Birds," was in error in supposing that the term sporves, so frequently occurring in the "Household and Privy Purse Accounts" of the L'Estrange's of Hunstanton, referred to the sparrow, ${ }^{*}$ although in one

* A correspondent in "The East Anglian" (vol. iii., p. 266) signing himself "Alpha," in commenting upon some editorial remarks fouuded upon my reference to the "spowe," in the first volume of this work, quotes the following passage (to prove that the sparrow was "a recognised article of food long anterior to the date of the Hunstanton Houschold Book"), from the "Boke of Nurture," written by John Russell, Usher and Marshall to "good Duko Homphrey, of Gloucester," between 1104 and 1417, as recently 
instance where the word "sparrouse" occurs-namely, "Itm xij sparrouse of gyste" (articles given in lieu of rent), no doubt Passer domesticus was really intended, inasmuch as at that time, and in that sterile portion of the county, it would probably be considered a rarity as well as a delicacy for the rich man's table. The fact also that spowes in the L'Estrange "Accounts" are nearly always mentioned in connection with other shore-birds, such as knots, ring-dotterel, redshanks, \&c., * all easily procurable then, as now, from Hunstanton beach, seems to confirm the impression that some grallatorial species was thus designated; and that this was no other than the whimbrelt is, I think, sufficiently evident from the fact that in Iceland,

printed in a collection of "Tracts on Manners and Meals in Olden Times," and edited for the English Text Society by Mr. Furnirall.

"Curlew, brew, snytes, quayles, sparowes, and martenetts rost" are mentioned as part of the third course in the directions for "a dynere of flesche;" and in the "Boke of Keruynge," printed by Wynkyn de Worde, in 1413, under the head of "serving of flesshe," the same classification of birds occurs, "curlewe, brewe, snytes, quayle, sparowes, and martynet." Tho this "Alpha" has also appended a note by Mr. Furnivall, in which that author suggests that "brewe" as mentioned three times in Russell's "Boke of Nurture," is no other than the whimbrel, adding, "I have a recollection (or what seems like it) of having seen the name with a French form like whimbreau."

* "Itm iij spowes of gist."

"Itm to Mr. Vicar of Thormhm svnt in rewarde for bryngyng of iij plovs, iij spowes, and a red shancke."

"Itm pd to je fowler at Corbetts for iij duss and di [dozen and a-half] of stynts, $\nabla$ spowes, iij whyte plors, and ij redshanks, and ij sedotterells."

"Item ii spowys of gyste."

† In Messrs. Gurney and Fisher's List ("Zoologist," 1846) the samo opinion with respect to the whimbrel is thus given, "Wo have reason to believe that it is this species which is occasionally mentioned in the 'Accounts' of the L'Estrange's of Hunstanton." 
Norway, Sweden, and Denmark, the names "spói," "spou," "spof," and "spove," are respectively applied either to this bird or the curlew, whilst the curlew is specially and repeatedly named in the L'Estrange accounts.

\section{TOTANUS FUSCUS (Linnæus).}

\section{SPOTTED REDSHANK.}

Although not specified in our earlier local records, the Spotted Redshank, no doubt, visited our coast in former times as frequently as, and probably more numerously than, it does now, but its identification, owing to great differences in plumage (a matter of age as well as of seasonal change), was evidently an ornithological riddle not easily solved, and hence the numerous synonyms, * attached by authors to this one species. By Messrs. Gurney and Fisher it was accurately described in 1846 as " not uncommon about the end of summer and early in autumn, the specimens so occurring being generally young birds ;" but their remark that it is only "occasionally obtained at other periods of the year," seems somewhat at variance with recent experience. This, however, merely indicates, what is observable in other migratory species, that, of late years, their stay is less prolonged on their southward passage, the main body passing over us altogether, and a few stragglers only marking their autumnal move-

* Besides the name adopted by Yarrell this bird has been described as the dusky sandpiper, dusky snipe, black-headed snipe, spotted snipe, black redshank, Courland snipe, and Cam. bridge godwit. 
ments. To what cause, in particular, this may be attributed it is difficult to say, but it is by no means improbable that the increased persecution of gunners may render the old birds, when in company with their young broods of the year, more difficult of access, and also the fact that there is now much less ground suitable to them, owing to improved drainage. Be this as it may, it is evident that for the last eight or ten years, at least, the spotted redshank has appeared on our coast, with but few exceptions, during the vernal migration, and consequently the majority of birds obtained have exhibited, more or less, the distinctive characteristics of their breeding plumage.*

Under the name of the Cambridge godwit, in Sir W. Hooker's MS., I find the first notice of the occurrence of this species in Norfolk, a specimeu shot near Yarmouth, on the 29th of October, 1818; and in Messrs. Sheppard and Whitear's "Catalogue" (1824-5) it is thus mentioned, "A bird of this species in autumn plumage, was killed at Yarmouth, and preserved by Mr. Youell. Another shot, near Ipswich, is now in the British Museum. Mr. Wigg, of Yarmouth, has also seen two other specimens which were shot near that town." On the 22nd of September, 1828, Mr. Rising, of Horsey, killed three out of a flock of twentyfive which appeared in that neighbourhood; and in Hunt's List, in 1829, under the name of the "spotted snipe," one specimen is said to have been procured at

* Of the nesting habits of this species Mr. Hewitson ("British Birds' Eggs," 3rd ed., vol. ii., p. 326), gires a most interesting description from the pen of the late Mr. Wolley, who discovered it in northern Lapland, breeding in the midst of the forests; and to quote his own words, "here is one of its most unexpected singularities - a marsh-bird choosing the driest possible situation, even hills of cousiderable height, and covered with forest timber." 
Cromer, and a pair in the Norwich Museum to have been killed at Yarmouth.*

Selby (1833) figures a young bird shot near Yarmouth, which was presented to him by the late Mr. H. Girdlestone, of that town; and another Yarmonth specimen, in the Saffron Walden Museum, was also obtained at Yarmouth in 1833.

On the 2nd of August, 1848, a female, shot at Salthouse, is recorded by Messrs. Gurney and Fisher in the "Zoologist" (p. 2292); and from Mr. Dowell's notes I find that a second specimen was lilled the same year at Salthouse, on the 6th of September. Mr. Upcher, of Sherringham, has an immature bird, shot at Salthouse some few years back. Here also must be noticed, although not seen in this county, the occurrence of a large flock of these birds on the other side of the "Wash," near Wisbech, in 1849, of which Mr. T. W. Foster, of the Wisbech Museum, gives the following interesting account in the "Zoologist" ( $p$. 2623) :- "Eight specimens were caught in a plover net on Guyhirn Wash, on the 11th instant (October), all of which are now in my possession; two of the specimens were undergoing the change between the summer and winter dress; the other six liad assumed it. Upon dissection, five of them proved to be males and three females. A flock of twelve were seen, eleven alighted, but in taking them out of the net, three escaped. Pennant named this bird the Cambridge godwit, probably from its being commonly found in that

* Neither this pair nor a specimen killed at Elveden, Suffolk, by General Newton, somewhere between the years 1838 and 1841, and recorded I believe, at the time, by the late Mr. Salmon, in Loudon's magazine, are now in existence, having been unfortunately destroyed by moth; but an immature bird, in the Museum collection (No. 218a), is marked Norfolk, although the date is not given. 
locality; but of late years it has become so exceedingly searce, even in its once favourite haunts, that to my knowledge more than sixteen years have elapsed since any were shot here."

Of more recent instances of the occurrence of this species in Norfolk, I extract the following from $\mathrm{my}$ own notes, the chief portion of the birds having been obtained in spring late enough to have acquired their dark nuptial plumage :-

1851. September 11th. A single bird was procured at Clenchwarton, near Lynn, as recorded in the "Naturalist" for 1852 (p. 170) by Mr. T. Southwell.

1854. August 3rd. A female was shot at Burgh, near Yarmouth. A pair in winter plumage in the Dennis collection at Bury, marked "from Yarmouth," but with no date attached, were, I have no doubt, obtained about this time.

1859. May 7th. A pair shot near Yarmouth.

1861. May 10th. One in full summer plumage was shot at Yarmouth.

1862. May 2nd. A fine pair in full summer plumage were shot near Yarmouth, with many other rarities during the spring migration. Of these birds Mr. F. Harmer writes in the "Field" (vol. xix., p. 494), "one was shot from a punt as it was feeding on the mudflats, on the inland tidal water near that town; the other was shot in the marshes by the side of a dyke, about a mile and a-half from the place where the first bird was killed; they were each alone, and easily approached when shot." Another correspondent in the same week's paper speaks of four having been seen on Breydon at that time, of which two males and one female were shot.

1863.* May. One obtained on Breydon.

* I find no notes on this species for $186 \mathrm{t}$ and 1865, but in the 
1866. May 20th. A pair in the possession of the Rev. M. A. Mathew, of Weston Super-mare, for the knowledge of which I am indebted to Mr. J. E. Harting, were killed on Breydon in full summer plumage, with other scarce migrants.

1867. October 5th. An adult bird killed at Yarmouth.

\section{TOTANUS CALIDRIS (Linnæus).}

\section{COMMON REDSHANK.}

That the shy clamorous Redshank should still fiequent our marshes during the breeding season, to be classed as a resident as well as a migratory species, is but another proof of the affection of these wild races for their long accustomed haunts. Drainage and cultivation, by changing alike the nature and the aspect of the soil, has more effectually banished the redshank and the snipe, in very many localities, than years of indiscriminate egging* had been able to accomplish, and that such is the case was evinced in a very remarkable manner in the great "flood" year" of 1852-3, when some thousands of acres in the "Fen" district were laid under water, by the bursting of the river bank

latter year Mr. F. Hele, of Aldeburgh, in Suffolk, recorded in the "Field" of September 16th, the occurrence of a pair at Thorpe mere, "very rare in that neighbourhood."

* Mr. Lubbock, speaking of the wholesale robbery of the lapwing's nests, says, "Nearly a bushel of eggs have been gathered by two men in a morning, principally from this bird; but the redshank, the reeve, and various terns were also put under contribution, their eggs, though smaller, being equal in point of flavour; and being less inclined to lay again and more impatient of the theft than the lapwing, this system of robbery did them much more harm." 
near Southery. Throughout the winter this portion of the county, which had so suddenly re-assumed its normal condition, was the resort of large numbers of wild fowl, and in the following spring the redshank, which had ceased to breed in the Hockwold and Feltwell fens for some years, returned to nest on the borders of the newly formed lakes, ${ }^{*}$ together with the black tern and the black-headed gull, known only by tradition as former denizens. In that western district, prior to the drainage of the fens, redshanks were extremely plentiful, although their nests were constantly robbed, and the eggis, like those of the lapwings, were sold for threepence apiece.

Messrs. Sheppard and Whitear in 1825, speaking of the abundance of this species during the breeding season in the marshes of Norfolk and Suffolk, describe it as "more common than any other wader," and such it no doubt remained for several years later, not only in the "Broad" district, but along our extensive seaboard, wherever the sand-hills are skirted by salt or fresh water marshes. Some eighteen or twenty years ago redshanks' eggs were sent regularly every spring to the Norwich Market from Salthouse, Blakeney, Warham, and similar localities, together with those of the oystercatcher, ringed plover, and the

* Mr. A. Newton tells me that on the 6th of May, 1853, he was shown a nest in Hockwold Fen, containing one egg, and that on the same day a man took one with three eggs, at Methwold. On the th of Jume he and his brother Edrard found on the edge of Wangford Warren (in Suffolk), close to a mere on which the black-headed gull used formerly to breed, an old redshank which, from its actions, evidently had newly hatched young ones, though these could not be discovered. On the 17th of June Mr. Edward Newton found a nest with four much incubated eggs in Hockwold Fen. In none of these localities had the species been known to breed for many years previously, nor has it done so since, so far as these gentlemen are arrare. 
common and lesser tern; but, at the present time, this species is but thinly scattered along our coast line, a pair here and there remaining to rear their young if happily located on preserved ground, and even in the most favourable portions of the broads its numbers are few indeed in comparison with former times. I am happy to state, however, that since the spring of 1865, from some cause for which I am quite unable to account, I have heard of more nests at Hickling and Horsey, near Xarmouth, and amongst that network of smaller broads that border on the Bure and the Ant, than have been known, even in such tempting spots, for some years. At Hoveton, in 1867, I had the pleasure of seeing several pairs on the wing, mingling their shrill notes with the wail of the lapwings, as I searched for their nests in the rough marshes, but here protection is afforded to both parents and eggs, and the owner of this birds' paradise, as a keen naturalist, is more than repaid for his hospitality. During the same summer, also, and again in 1868, in sailing from Norwich to Yarmouth, I was agreeably surprised to hear the notes of these birds, and watch them on the wing at many points of the river, a fact sufficiently unusual now-a-days, in that neighbourhood, to be remarked by the reed-cutters and watermen on the river. On the western side of the county* they still breed regularly on East Walton common, near Westacre, one of the few "wet" commons remaining in Norfolk, and in this unlooked for swamp, bordering upon the old bustard country, I saw some five or six pairs in May, 1867, and learned from Mr. Hamond's keeper that they were even more plentiful during the previous summer.

* Mr. Southwell obtained some nests in this district in 1854; and Mr. A. Newton tells me that the late Mrr. Selby's collection contains specimens taken at Didlington, in 1856.

$2 \mathrm{E}$ 
Grateful to the ear as the melody of the song thrush, when heard from the branches of the yet leafless trees, or the first whistle of the stone-curlew and the ringed plover in their desolate haunts on the warrens and "breck" lands, is the scream of the redshank in the early spring, just returned to its summer haunts amidst the broads and marshes. In such localities, in very mild seasons, they may be heard as early as the middle of February, but are more generally seen in pairs about the beginning of March, when their nervous actions and swift jerking flight, added to their incessant and clamorous cries, ${ }^{*}$ enliven the dreariest waste of marshy ground. It is noticeable, also, that the cock redshank, in the breeding season, has a "song" of its own, quite as much so as the ringed plover or the common snipe. More than once, too, in the early spring, I have seen the male bird, as $\mathbf{M r}$. Lubbock describes it, "pirouetting" on a gate post, now running quickly along the top rail calling loudly to its mate, now bowing and fluttering like an amorous pigeon, and less mindful of danger than at any other time. With Thompson ("Birds of Ireland," vol. ii., p. 205), I am inclined to think that "what may seem timidity or fear on the part of the redshank, should rather be attributed to restlessness of disposition," shown as much when in pairs as when in large congregations. The first eggs are usually laid by the middle of April, and the nests are so artfully con-

* Mr. W. H. Power, in some interesting notes on this species ("Zoologist," 1866, p. 125), alludes to their habit of "rising and falling in the air [in their spring flight] with a tremulous motion of the wings, at the same time making a trilling noise," and adds that at night, for they never appear to rest, beside their usual note uttered when on the wing, they will join in a sort of chorus, "one bird beginning and others chiming in, one after another, much in the same manner as a flock of ducks assist the old drake in his clamorous quacking." 
cealed that unless their construction is known many might pass unnoticed in a very small space. A hollow is formed in the centre of a tuft of grass, part of which trodden down forms the only lining, whilst the remainder, arching as it were over the top, effectually conceals the eggs from view; and as the bird enters and leaves it from the side, and the grasses are either drawn or fall naturally over the openings, the little runs thus made in the surrounding herbage are the only guides to its whereabouts. I have examined several of these singular evidences of instinctive wisdom and have always found four to be the full complement of eggs, laid in a slight hollow with their small ends inwards.* During incubation, and more especially when the young are hatched, the parent birds become even more difficult of approach, and leaving their nests like the lapwings, on the first alarm, fly screaming round the intruder, their anxiety being evinced by strange aerial evolutions. On the 24th of May, 1863, I flushed a pair in some rough marshes, lying parallel with the beach $\dagger$ between Holme and Hunstanton, and

* A very full and accurate description of the nests and eggs of this species will be found in the "Zoologist" for 1867 (p. 602), forming part of the "Oological Notes from South-east Essex" of Mr. W. Vincent Legge, F.Z.S.

† Thompson, who in his "Birds of Ireland" has given by far" the best account of this species of any British author, states that on some parts of the Irish coast the redshank lays its eggs on the gravelly or shingly beach, like the ringed plover, but I have never heard of any similar instance in this county, although it is possible such may have been the case when they were formerly more abundant. By the author of "British Birds in their Haunts" the nest of the redshank is also said to be placed in the marshes by the sea, " under a shrub (popularly known on the coast of Norfolk by tho name of 'rosemary'), the Suoeda fruticosa, Shrubby Sea Blite of botanists." The same authority, moreover, from his own observations, confirms the statement of a writer in the "Naturalist," as

2 E 2 
presuming from the actions of the birds they had either eggs or nestlings, I determined to watch them from the neighbouring sandhills, and if possible discover the position of the nest. Time was no object on that bright summer's morning, so that I seated myself, glass in hand, prepared to match my patience against their parental solicitude. Although at a considerable distance they seemed quite aware of my presence, and and with a rapid sweeping flight circled over the marsh, sometimes soaring high in the air as if about to leave altogether; at others, swooping close to the ground, but never stopping for an instant in any one spot. At length the area of their flight diminished by degrees, though their agitated cries were loud as ever, and first one bird alighted, with a quick short run and vibratory motion of the wings and tail; then another, but far apart, and both stood motionless as a ring dotterel on a ridge of shingle. Presently one, which I supposed to be the male, again took wing, and dashing to and fro, even more wildly than before and with redoubled clamour, seemed desirous to attract all attention to itself; but whilst admiring the cleverness of this little ruse, I took care to keep my glass fixed upon its mate, and soon had the satisfaction of seeing her run hastily to a thick grassy tuft, and there with trembling wings caress her young ones. Marking the spot exactly, I started from my post, but long before I reached it both birds were again on the wing, now dashing over my head in the wildest excitement, and loudly wailing as I stooped to search amongst the long coarse grasses. There they were sure enough, three

quoted by Yarrell and Macgillivray (though discredited by the latter) that this species, in boring for food, "dart their bill into the sand nearly its whole length, by jumping up and thus giving it a sort of impetus by the weight of their bodies pressing it downwards." 
little downy things but a few days old, though not in the nest, which I subsequently found at a short distance, and even then, but for their bright beadlike eyes I might have passed them by unseen.* After all my trouble I could not help stopping a few minutes longer to examine these beautiful little creatures in their soft russet coats, barred on the back and wings with two shades of brown, and their leg's as strangely disproportioned to their bodies as those of a foal in its earliest stage. Then, with something of regret, as I very much wanted a specimen, I put the youngsters back into their tuft of griss, but was fully repaid by wituessing, from my former vantage ground, the meeting between old and young.

As a further instance, also, of the affectionate solicitude of the redshank for its progeny, I am enabled, through the kindness of Mr. Rising, of Horsey, to give the following interesting anecdote. "On the 29th of May, 1868, as a marshman was 'quanting' his boat over Hickling broad, he was suddenly attracted by the peculiar notes of a couple of red-legs [as they are commonly called in Norfolk], which kept flying slowly and very low over the water, evidently bent upon an onward course, but detained by some peculiar cause of anxiety as they took no notice of him whatever. As he drew closer, he observed something swimming in the water, which on a nearer approach proved to be three little redshanks. Still perfectly indifferent to his presence, the old birds proceeded with their 'labour of love,'

* Mr. W. H. Power, in the paper before referred to, describes the capture of a young redshank, which, from a kind of ventriloquism in its chirping notes, seemed to be always at a little distance, first in one direction and then in another, but was at length discovered, nearly at his feet, when he was about to give up the search as hopeless. 
leading and directing, and, as it were, encouraging and pressing them forward, and thus they continued to progress slowly but surely, till they were not only out of sight (for the man kept on his separate course), but till the cry of the old birds died on his ear." From the line they were taking and the direction whence they had come, Mr. Rising has no doubt that the old birds were changing their feeding-grounds from the Pleasure-boat hill to a place called Rush-hill, a distance of some five hundred or six hundred yards, and were thus watching over and leading their young.

At the close of the breeding-season our native redshanks again leave the broads and more inland haunts for the sea coast, frequenting more particularly the salt-marshes and brackish margins of our tidal streams. At Blakeney, as Mr. Dowell remarks, "they assemble in small flocks about the middle of September, and are particularly shy and noisy;" and from their thus disturbing all other wild fowl, are objects of much aversion to the sportsman and professional gunner.* These form, however, but a small portion of the flocks, which assemble in these localities during the autumn months, consisting of migratory families from the north, and which leave us again after a time for more southern quarters, although a few may still be met with even in the sharpest weather. Again during the spring migration this species appears on Breydon and other parts of the coast, in company with knots, godwits, and ringed plover, staying only for a few days, and then passing on to their northern breeding grounds. This

* It is this habit of the redshank, and also of the turnstone (as Mr. A. Newton informs me), that has giren botl birds in many parts of Scandinaria the local name of "Tolk" or interpreter, the origin of the specific appellation interpres given by Linnæus to the bird last mentioned ("Linn. CEl. och Gothl. Resa," p. 217). 
occurs generally about the first week in May, when our own residents are occupied with their first sitting of eggs.

A specimen killed at Yarmouth, in April, 1862, and which is still, I believe, in Captain Longe's possession, was at first mistaken, ${ }^{*}$ from the light colour of its legs and certain peculiarities of plumage, for the yellowshanked sandpiper (Totanus flavipes), but on comparison with skins of the latter bird from America, it proved to be only $T$. calidris in an immature and somewhat exceptional state, and I have since met with a similar example.

As an article for the table, the redshank is of but little repute at the present day, being sold by the gunners for about two shillings a dozen; and even Sir Thomas Browne alludes to it as "of common food, but no dainty dish." The numerous entries, however, of this species, in the L'Estrange accounts, together with plover, spowes, and other shore-birds, show that they were generally eaten at that time; and in the Northumberland "Household Book" they are ordered " to be bought at Princypall Feestes for my Lordes owne Mees after jd. ob. [three half-pence] the pece."

\section{TOTANUS OCHROPUS (Linnæus).}

\section{GREEN SANDPIPER.}

The question as to the breeding of the Green Sandpiper in England is still a disputed point amongst British ornithologists, but as soon might we expect an English

* I have an impression, although I cannot now find the reference, that this bird was recorded at the time, in the "Field," as the true Totanus flavipes. 
dictionary to prove a key to the literature of continental Europe as that a perfect knowledge of the habits of our feathered migrants should be acquired only by local observations. Hitherto, as far as Norfolk is concerned, this problem remains unsolved. The mere fact that individuals have been procured in the county, in every month of the year, is no more conclusive as to its breeding with us than is the case with the golden or grey plover, the knot, sanderling, or other similar migrants; but as regards this particular species there is one very exceptional and important consideration, namely, that of late years the researches of European ornithologists have established a strange peculiarity in its breeding habits; indeed, to borrow a common American expression, naturalists and greensandpipers, in this respect, have been hitherto alike "up a tree." It matters not how much our preconceived notions of the proper locality for the nest of a wader may be upset by an inspection of $\mathrm{Mr}$. Gould's plate in his "Birds of Great Britain," the fact is indisputable that the green sandpiper deposits its eggs, many feet from the ground, in the deserted nests of the song thrush and other arboreal species. If such, then, is its ordinary habit in other countries, may not our ignorance of this singular custom account for its eggs never having been taken in England, although very young birds are recorded to have been seen?

This very remarkable peculiarity seems first to have been brought to the notice of English ornithologists in a review which appeared in the "Ibis" for 1859 (p. 405), but even then judgment was suspended by the writer, who considered that the assertion required further testimony. This was forthcoming a few years later, but space will not admit of my quoting more than a few extracts from a paper on this subject, by $\mathrm{Mr}$. Alfred Newton, in the "Proceedings" of the Zoological 
Society for 1863,* but I would strongly recommend its perusal to all who are interested in the history of this particular species. From the "Naumannia" for 1851 and 1852, he cites one or two instances of the discovery of the nesting of this sandpiper upon trees, on the authority of Herr Pässler and Baron von Homeyer, the latter stating that during his stay at Haff he had seen many nesting places, which were on the borders of the alder-wastes " in the middle of the forest where the trees stand upon hillocks." Again from the "Journal für Ornithologie" for 1855, we have the evidence of Herr Wiese, who, writing on the ornithology of Pomerania, especially in the district of Cöslin, admits his former disbelief in the statement of an old sportsman, that Totanus ochropus laid in old thrushes' nests, nor was he at all convinced until some years after, in 1845, when "he obtained from the same man four fine eggs of a bird of this species, which for some years had been wont to nestle in an old beech tree." His scepticism however, vanished altogether in the following spring; when he himself found a nest of the bird on a pine which had a fork about five and twenty or thirty feet high, wherein he discovered "four eggs on a simple bed of moss." In the spring of 1853 he also took four eggs, and in 1854 "found a nest placed in the old nest of a song-thrush, out of which the shed buds of the beech had not so much as been removed." Again in the "Naumannia" for 1856 and 1857, Dr. Altum describes the annual nesting-places of this species as misseltoe-thrushes' nests, "often some hundred yards distant from the nearest pool, and their height fifteen feet or more from the ground;" and in the same district, on the 6th of May, 1855, Herr W. Hintz found

* Vide also the "Zoologist" for 1864, p. 9115. 
three eggs on an alder in an old dove's nest, as he thinks, though he states it might have been that of a jay. Previously he had only observed this sandpiper to use old nests of Turdus musicus, excepting once when he found some young ones, only a few days old, hard by a river bank on a layer of pine needles on an alder stub. With a brief allusion to the remarks upon this subject, by Herr Bädeker and Dr. Baldamus, amongst foreign ornithologists, and the review of the same in the "Tbis" already mentioned, Mr. Newton concludes with a reference to the published notes of the late $\mathrm{Mr}$. W. $H$. Wheelwright, who, under the signature of "an Old Bushman," made known, in his communications to the "Field" newspaper, his own experience of the green sandpiper's way of nesting in Sweden; and the following portion of a letter received by him from his friend Pastor Theobold, of Copenhagen (dated November 27th, 1861). "The nidification of Totanus ochropus is so remarkable that I do not fear to trouble you with the history the Forester Hintz [mentioned above] has given me. He writes,-'This year I succeeded in finding the nest of Totanus ochropus. On the 9 th of May I took four eggs of this bird; they were found in an old nest of Turdus musicus, and seemed to have been incubated about three days. The very same day there were brought me four other eggs of this bird, also found in a thrush's nest. * * * The 10th of May there was shown to me a nest, thirty feet high, on an old birch, the bird having chosen an old decayed nest of a squirrel. This nest was the highest I have ever seen. Three young ones had just been hatched; in the fourth egg the bird was about to break the shell. One jumped down and concealed itself on the edge of a water-pool. The 11th of May a nest with four fresh eggs was found, but they did not come into my hands; this was in an old pigeon's nest on a 
Pinus rubra, and full of dry pine-leaves. The 20th of May two eggs, almost burst by the young, were found in an old thrush's nest, the two missing birds having most likely already left the nest. The $22 \mathrm{nd}$ of May four young ones, apparently but a few hours old, were found in the old nest of a Lanius collurio, in a juniper, three feet high. The 24th of May four young ones were found in the hole of a Populus tremula thrown down by the wind. The year before Muscicapa luctuosa had its nest in the trunk as it lay on the ground; this year Totanus ochropus had chosen the same opening. When I approached the trunk, the young ones, perhaps fourand-twenty hours old, jumped away and hid themselves in the grass among the branches. All these nests were near the water-two on the edge of a rivulet, the others on wet morasses, the distance from the water being at most six feet." "'

In further coroboration of the above, I may add that M. Gerbi in his revised edition of Degland's "Ornithologie Européenne" (vol. ii., p. 226), mentions his having received from the department of the Basses-Alpes eggs of this species, said to have been found in a nest placed on a bush by the side of a torrent. Herr Westerlund, also, in his "Skandinavisk Oologi" (p. 201), quotes from a Swedish sporting magazine an account given by a gamekeeper that he had found this bird's eggs in a squirrel's nest, and that the nestlings reach the ground by the very simple method of being thrown down by their parents while quite young, their thick downy clothing protecting their light bodies from harm.

Having thus far digressed, in order to show how much our home naturalists* may have been misled, in

* Mr. Knox, in his "Ornithological Rambles in Sussex," makes one most important statement in his notes on this species--viz., that four observed in June, 1843, "on the borders of a pond 2 F 2 
their efforts to discover the nest of the green sandpiper,

- I will now give, from our local authorities, a few of the instances in which this species has been supposed to have remained with us for breeding purposes. Chief amongst these is the well known communication from Mr. Lubbock to Yarrell, also recorded in the "Fauna of Norfolk" that he had been informed by Sir Thomas Beevor "that one of these sandpipers built in a hollow on the side of a clay pit upon his estate, in the autumn of 1839, and hatched four young, which, to his vexation, were taken by a shepherd's boy. They are common during summer and autumn upon a small stream which runs through his property near Attleborough." At that time, of course, the clay-pit was looked upon as a not unlikely locality for the nest of

through which ran a clear trout stream, at Cocking, near Midhurst," invariably betook themselves "into the great woods in the immediate neighbourhood" when disturbed at the pond, and suspecting that they might after all be examples of the wood sandpiper (Totanus glareola), one was shot in the following July, but proved to be T. ochropus. The probability, also, of this sandpiper occasionally breeding in North Lincolnshire has been recently mooted by Mr. Cordeaux, of Great Cotes, Ulceby, in the "Zoologist" (s. s., p. 1412 and 1459). In his own and the adjoining parish of Aylesby, a pair or two have been observed during the last three summers, and a farmer, whose land adjoins the small stream which they frequent, at the latter place, assures $\mathbf{M r}$. Cordeaux that towards the end of July, 1868, he observed "four young birds along with the old ones sitting on a sand-bank in the "beck." "They were "quite little things," and could "only fly a few yards at once"; they were quite a different colour to the old birds-"much lighter." They were all seen for some weeks after, about the same spot, and one of the young birds was shot and sent by his informant to Mr. Cordeaux, who unfortunately was from home at the time, and was therefore nnable, as the bird was not preserved, to confirm his evidence, but he is himself perfectly satisfied with his authority. The young bird was said to be "about as large as a jack snipe." 
this bird, but though Mr. Lubbock has recently assured me that he took much pains to sift the case, and has no doubt of the fact; yet with the light recently thrown upon the habits of this sandpiper, one must be allowed to question the actual nesting in the clay-pit, * although it is quite possible that the young birds, reared close by, were taken by the old ones to the clay-pit as a convenient hiding place. Again, on the 26th of July, 1840, Mr. Lubbock observed a small party of six by the side of a small rivulet, which had been previously seen in the same spot on the 23rd. "By creeping (he says) on my hands and knees I obtained a good view of them as they walked about on a mud bank, and believe, from the duller look of the plumage of some, that they were two old birds with a brood of young ones." In some interesting notes on this species, by Mr. L. H. Irby, in the "Zoologist" for 1853 (p. 3988), an adult female is described as killed at Saham, on the 14th of June of that year, "after having been noticed in the vicinity for several days," but even at that late period the breast was not denuded by incubation, " nor were the eggs at all larger than hempseed." Messr's. Sheppard and Whitear had evidently a strong impression that the nest of the green sandpiper might be discovered

* I have by no means overlooked the statement of Mr. Hew. itson, in the third edition of his "Eggs of British Birds," that the Rev. H. B. Tristram found fresh eggs of this species in Norway, at the beginning of July, from which the figures in his work were taken, and that one nest is said to have been placed "among grass by the side of a sluggish stream;" the other two "among fine pebbles by the banks of mountain tarns, which had a considerable space of muddy shingly shore." These eggs appear to have been taken between Bodö and Quickjock, in Lapland; but Mr. Newton, in the paper before quoted, suggests the possibility of a mistake in the assertion, inasmuch as "this particular district has been since visited by three other excellent observers, to no one of whom did the green sandpiper reveal itself." 
in Suffolk, when they wrote "we cannot positively affirm that this species breeds here, though it seems probable that it sometimes does so, as five green sandpipers were constantly found one summer near the old decoy at Levington, in Suffolk;" and Mr. Salmon also appears to have been of the same opinion, as, in a paper "on the arrival of twenty-nine migratory birds near Thetford," in Loudon's " Magazine of Natural History" for 1836 (p. 524) he writes, "I have the following entries of disturbing this bird during the summer of 1835-June 21st a single bird; July 19th a pair; July 29th three pairs, all together; August 3rd a pair; and September 8th a small flock of several individuals; and during the present spring-April 15th, 20th, and 29th, and May 18th only a single bird at each time. Judging: from these circumstances I suspect it breeds in our immediate neighbourhood." In the same locality, too, Messrs. A. and E. Newton have often made similar observations, and have told me of a single bird which constantly, when flushed by the side of a pond, flew into a large and thick plantation of Scotch-firs.

Such, then, as far as it goes, is all the evidence $I$ can give bearing on this much debated and most interesting subject, but I have failed altogether to discover the grounds upon which Messrs. Gurney and Fisher have stated, with respect to this species, that "a few well authenticated instances of its breeding in Norfolk are on record." Whether it does or does not, however, occasionally breed with us, the green sandpiper must be classed amongst our regular migrants, appearing singly or in pairs during April and May, and in small family groups, rarely exceeding six in number, on their return southwards at the end of July or beginning of August.

An approximate idea of their proportionate numbers in every month of the year may, I think, be gathered from the following table of such specimens as I find 
recorded in my own notes for the last eighteen years; and which plainly shows that there is no month in which one or more examples are not occasionally met with :-
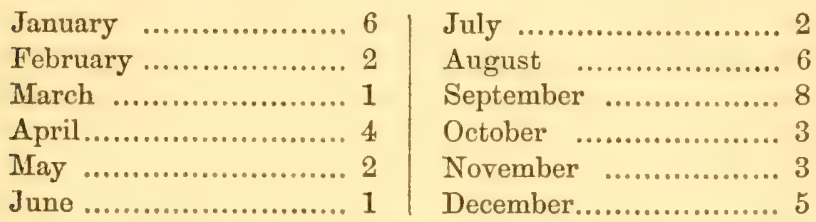

Mr. Lubbock states that he has generally seen these birds when snipe shooting in March, but never observed one later than the 11th of April; from the above list of specimens, however, I find the 23rd and 30th of April and the 5th of May the latest dates of their appearance in spring, and the 28th of July (a bird killed at Yarmouth, and, therefore, probably a fresh arrival), the earliest date of autumnal migration; the usual period being between the 3rd and 12th of August.

One example killed on the 1st of July, 1854, and another on the 27th of June, 1861, in the marshes between Acle and Yarmouth,* may have been either stragglers that had not paired off for the season, or birds that had really remained to nest in that neighbourhood. The number of specimens, also, obtained in December and January is quite confirmatory of Mr. Lubbock's remark that this sandpiper is to be found in its accustomed haunts in the depth of winter, even with "deep snow on the ground, and all the snipes driven out of the county by stress of weather." This was particularly observable during the intense frosts which prevailed in the winters of 1859-60 and 1866-67, and it is remarkable that at the latter period, when even our rivers

* In Messrs. Paget's "Sketch of the Natural History of Yarmouth and its Neighbourhood" this bird is described as "not uncommon." 
were frozen over, more green sandpipers were brought to our birdstuffers between the 1st of December and the 18th of the following January, than in any previous twelve months. All that I then handled were in excellent condition.

It should be here remarked, too, that since I commenced my ornithological notes in 1850 , the past year (1868) is the first in which I find no record of the occurrence of this species, proving, at least, that if not entirely absent they were unusually scarce; and I cannot help agreeing with Mr. F. D. Power, who, in his notes from Rainham in Kent, and its neighbourhood, in the "Zoologist" (s. s., p. 1498) also mentions the extreme scarcity of this species in 1868 as compared with their numbers in the previous year, that this is probably attributable to the severe drought and "the drying up of the ditches during the summer."

Provincially this bird is known as the "Summer Snipe," a term also applied to the common sandpiper (Totanus hypoleucus) and the "Martin-Snipe," a name probably derived from the base of the tail feathers and the tail coverts being pure white, forming a marked feature as it takes wing, and giving the bird somewhat the appearance of the house-martin. At the time of its vernal and autumnal migration examples are occasionally met with on the coast or in the adjacent marshes, both salt and fresh water, but as a rule its haunts are more inland than by the sea, and though pretty generally distributed, it exhibits a marked preference for the black peaty soil which characterises the low grounds to the south and south-west of the county. Thus at Hapton, Flordon, and Forncett, in certain favourite spots, one or more are almost sure to be met with in any season, as well as on that small chain of fens, which are situated on the river Thet, near Hargham, Buckenham, and Attleborough. In the immediate neighbourhood of Norwich 
I have known them killed in the marshes about Thorpe, Lakenham, Cossey, and Bowthorpe, and I have also flushed them from the drains which surround the snipe-grounds on East Ruston common; a rough peaty swamp lying not far from the coast to the extreme north of the county. I find no record of the appearance of this bird on the Broads themselves, which is no doubt owing to those sluggish waters, covered with minute vegetation, and bordered with a dense growth of aquatic herbage, being little suited to their feeding habits. The banks of rivers and lakes have also far less attractions for this species than the shallow winding rivulet, or the " murmuring" brook, of our poet Laureate; * where, in the little bays that mark the winter's flood, the green sandpiper, with quick nervous actions, feeds by the water's edge under the sheltering bank. Always wary, however, it takes wing on the least alarm, and, as Mr. Harting remarks, from the fact of its usually rising silently and not whistling till at some little distance the sportsman's attention is only drawn to its presence when too late for a shot. As an instance, also, of its partiality for marsh drains, Mr. Lubbock speaks of its being most numerous in his experience at Norton, in Suffoll, in 1816, where "a range of meadow drains

* "With many a curve my banks I fret,

By many a field and fallow,

And many a fairy foreland set

With willow-weed, and mallow.

I slip, I slide, I gleam, I glance,

Among my skimming swallows,

I make the netted sunbeams dance

Against my sandy shallows.

I chatter, chatter, as I flow,

To join the brimming river,

For men may come and men may go,

But I go on for ever." 
having been cleared, and the mud thrown out on the sides," these birds were remarked in parties of five or six. The same author describes them, most accurately, as being always fat but having a "fulsome muddy smell," and their note, he says, is "probably the loudest of any of our fen birds" considering its size. This clear shrill whistle may be heard distinctly when the bird is passing over at a great height, and I have occasionally distinguished it on dark autumnal nights, not blended with the cries of other birds, but apparently uttered by some straggler, bewildered by the lights of the city and calling loudly in its flight. $\mathrm{Mr}$. Harting, who gives a full and most interesting account of this sandpiper from his own observations ("Birds of Middlesex"), describes its food as consisting of "insects, chiefly small beetles, spiders, small red worms, and wood-lice," to which I may add small fresh water-snails, found in the stomach of one killed at Langley in the month of December.*

\section{TOTANUS GLAREOLA (Linnæus).}

\section{WOOD-SANDPIPER.}

This species, as compared with the green sandpiper, is a rare visitant to our coast, appearing only occasionally, and at uncertain intervals, on its migratory

* Since the above was in type, Mr. J. H. Gurney, jun., has kindly communicated the following note on this species:- " $\mathrm{Mr}$. Alfred Roberts, of the Museum at Scarborough, has had the green sandpiper ( $T$. ochropus) several times from the neighbourhood of Hunmanby, in all cases shot in June. The keeper there says they breed in old crows' nests; he has seen them come off from the nests." 
course in spring and autumn. At such times, also, in company with other migratory waders, it is usually met with in close vicinity to the coast, and a very large proportion of the specimens procured in Norfolk have been lilled on Breydon. The very few records of this bird by earlier local authors is attributable in some degree, no doubt, to the fact that until of late years the marked difference of plumage between the wood and green sandpipers was but little understood. Yet, though probably never common, even as a migrant, this species is becoming more and more scarce in this county, as will be seen by the subjoined list of recorded specimens or such as have come under my own immediate notice. This growing rarity may perhaps be owing to the constant increase of drainage in many parts of the opposite shores of Holland where, within a few years, it bred numerously.

Messrs. Sheppard and Whitear omit this species altogether from their List of the birds of Norfolk and Suffolk; and a pair killed at Yarmouth in the spring of $1833^{*}$ are the only ones mentioned by the Messrs. Paget. Mr. Hunt speaks of two or three examples as having been killed at Yarmouth. A young bird figured by Messr's. Gurney and Fisher in the "Zoologist" for 1846 (p. 1324), which, together with an adult female shot at the same time, is now in Mr. J. H. Gurney's collection, was killed in a marsh, at Beechamwell, many years ago during the summer months, by Mr. Scales, of bustard celebrity. This youngster "not having" entirely lost its down," and being "evidently not sufficiently feathered to have crossed the sea," was naturally presumed "to have been hatched near the spot where it was killed;" and is the only instance in which the

* These birds, according to Mr. J. Clarke, are still preserved in the Saffron Walden Museum.

2 G 2 
nesting of this species* in Norfolk has hitherto been at all suspected. Mr. Lubbock, who describes this bird as very irregular in appearance and uncertain in numbers, states that "many years ago, when a large tract of marsh dykes were cleaned out, at Caistor, near Yarmouth, the wood, as well as the green species, were for a time quite abundant," showing in this respect a similar partiality for the dark peaty soil of the drains.

of more recent occurrences the following are the only examples with which I am acquainted:-

1847. April. One recorded by Messrs. Gurney and Fisher in the "Zoologist" (p. 1769), as killed at Yarmouth, about the end of April.

1848. May. Three specimens recorded by the same authors ("Zoologist," p. 2185) as killed near Yarmouth about the 9 th of May.

1849. August 2nd. Two specimens, male and female, recorded by Mr. L. H. Irby in the "Zoologist" (p. 3035) as shot at Yarmouth.

1852. On the 5th of May, during the great flood in Hockwold Fen, before mentioned, Mr. A. Newton saw a bird which he had every reason to think was of this species, and on the following day at the same place a pair. May 28th. A single bird was killed at Sutton; and three more at Yarmouth during the same week.

1854. April 22. One near Yarmouth; and on the 1st of July a bird, which I examined in the flesh, was sent up to Norwich to be preserved, together with a green sandpiper, a redshank, and a grey plover, all shot

* Mr. Hewitson ("Eggs of British Birds," 3rd ed., 2nd vol., p. 332) states that " on the 3rd of June, 1853, Mr. Hancock, after a long and persevering watch succeeded in discovering the nest and eggs of this species for the first time in Britain, at Prestwick Carr, near Newcastle." * * * "The nest was situated on a hillock, in a marshy part of the carr, amongst heather and long grass." 
on Breydon. The grey plover was in full summer plumage; but, as before stated, is a bird which is never known to remain with us for nesting purposes. A pair, in Mr. Newcome's collection, killed by the river at Hockwold, were procured, I believe, in this year during the early autumn; and from the appearance of their plumage, and other indications, were evidently young birds.

1855. August 22. Two specimens shown me in the flesh had been procured somewhere in this county.

1856. September 27. A single bird was killed at Burgh, near Yarmouth.

1852. May. One in Captain Longe's collection, killed on Breydon.

From this date, although it is quite possible that others may have been seen or shot, I know of no other occurrence of this species in Norfolk, but Mr. Fenwick Hele, in his "Ornithological Notes from Aldeburgh," in the "Field,"* shows that in 1867 they were unusually plentiful in that part of Suffolk.

* In the "Field" of May 25th, 1867, Mr. Hele states that at Thorpe Mere, on the 1st of May, he killed three mood-sandpipers; "they formed part of a small flock," which disappeared shortly after. Again, in the "Field" of August 24th, 1867, he writes"August 9th; a flock of wood sandpipers have frequented the First Mere for some days past. I have succeeded in bagging four altogether. The note is similar to that of the green sandpiper, but the flight is higher, and upon alighting these birds "fall" to the ground similar to the jack snipe." In the "Zoologist" for that year, Mr. F. D. Power also recorded an "extraordinary flock of rood sandpipers at Rainham, Kent." He states that on the 26th of July his brother "fell in with a large party of wood sandpipers on some marshes near Rainham." He shot one out of three that rose first," but at the report others rose on all sides, and, joining in one large flock, flew. round and round at some height, continually whistling; their numbers he estimated at from eighty to a hundred. After they had pitched again, he succeeded in bagging four more, as in small parties "they flew 
It is needless here to enter into any detailed description of the peculiarities in plumage of the wood and green sandpipers, as this point is so fully explained by Yarrell. My friend Mr. Harting, both in bis "Birds of Middlesex" and in a communication to the "Zoologist" for 1867 (p. 973), has also done good service in this respect, adding, moreover, one new point of difference, that "in the wood sandpiper the shaft of the first quill feather is white, the remaining shafts dusky; whereas in the green sandpiper the shafts of all the quill feathers are dusky."

\section{TOTANUS HYPOLEUCUS (Linnæus).}

\section{COMMON SANDPIPER.}

This species, familiarly known as the "Summer Snipe," visits us regularly in spring and autumn, though not in large numbers, seldom more than one, or at most a pair, being observed at one time in spring, or little family groups of half a dozen together at the close of the breeding season. About the first week in May they suddenly make their appearance with other migrants on our coast, and are then, also, for a few days pretty generally distributed over the county; frequenting the banks of our rivers, lakes, and larger ponds in prefer-

round the ditches like dunlins. Next morning he only met with one, and after that ouly occasionally came across a few, seeing the last on the 6th of September." Although the flock seemed to consist chiefly of young birds, he obtained one old female, which had not entirely lost its breeding plumage; they were all very fat. Previously he had only twice met with this species at Rainham-"one seen in July, 1865," and a second obtained on the 15th of July, 1866, on the same marsh where this large flock were observed. 
ence, as a rule, to smaller streams. They have a marked partiality, however, as I have myself observed, for sandy or gravelly soils, being thus attracted even to a short boat "staithe," or a pathway leading to some marsh-mill from the main stream.

When walling in the early summer by the banks of the river, or pulling leisurely along its winding "reaches" the presence of this elegant little bird is detected rather by the ear than the eye, as its clear piping notes resent intrusion on its haunts. If not too elosely pressed it runs nimbly on before us, flirting its tail up and down, and calling at intervals, or stopping now and again to pick up some morsel of food; whilst every action of its body evinces a nervous excitability, reminding one not a little of the wagtail tribe. If approached too near the pace is suddenly quickened, and spreading its wings and tail for flight the dark bronzed tints of the upper plumage contrast strongly with the pure white of the under surface, as it twists and turns in the air, uttering again a loud wheet, wheet, as it speeds on its way to safer quarters.

Why the Common Sandpiper should not breed in the Eastern Counties,* is as difficult to account for

* In Mr. A. G. More's paper "On the Distribution of Birds in Great Britain during the nesting season" ("Ibis," 1865, p. 436) this species is stated to be "scarce in the south during the breeding season, and apparently wanting in several of the southern and eastern counties. * * * Is reported to breed only occasionally in Cornwall, but regularly in North and South Devon and Somerset. In Dorset it becomes more rare." Mr. Knox describes it as "breeding regularly in Sussex," though scarce. It is "doubtful" if it breeds in Kent, and "appears to be wanting in several of the eastern and southern districts." Mr. J. H. Gurney, when staying at Pembroke in 1867, was also informed on good authority that the common sandpiper nests regularly in that county, selecting the banks of ponds for the purpose. At low tide they are constantly to be seen in the town of Pembroke feeding on the shores of the estuary (a branch of Milford Haven) which runs through the town. 
as the restricted range of the nightingale in England; but unquestionably, to the present time, there is no reason to suppose that it has done so. Stragglers have been seen in June; and old birds, accompanied by their young broods, have been observed here as early as the first week in July, and yet no former record, nor the experience of any living naturalist, affords a single exception to this apparently fixed rule. Mr. Salmon, in describing this species as a regular migrant in the neighbourhood of Thetford ("Mag. Nat. Hist.," 1836, p. 525), states that, "like the dotterel, it only visits us during its periodical migrations;" and Mr. Alfred Newton, whose experience is that of some twenty years later, is of the same opinion. Mr. Lubbock, in a recent letter, assures me that he has "never known the common sandpiper to breed in Norfolk," although some sixty years ago he remembers them not very uncommon on the river Yare, and has seen one as near Norwich as Carrow-bridge; "but almost always solitary, never more than two together." On the 9th of July, 1861, I met with two or three small flocks on the banks of the Bure, about seven miles from Yarmouth, a very favourite locality; and Mr. H. T. Frere ("Zoologist," p. 1876) thus mentions their most exceptional abundance on the same river near Wroxham, in August, 1847:- " I was much struck by the number of common sandpipers, which I saw flying up and down; there were many family parties of five or six, but on two occasions I saw a flock of as many as thirty or forty together close by me." By the beginning of September these birds again leave us for the south, but a single bird was killed by $\mathrm{Mr}$. J. E. Harting in 1863, on the Bure, within a mile of Yarmouth, as late as the 2nd of October.

The diving powers of this bird, which it possesses in common with several other allied species, is thus 
referred to by Messrs. Sheppard and Whitear-"Some years since we saw a sandpiper flying across a river attacked by a hawk, when it instantly dived and remained under water until its enemy disappeared. It then emerged and joined its companions." It is also said by the same authors to occasionally utter a note very nearly resembling that of the kingfisher.

I had always supposed that the following description of the "Maychit," in Sir Thomas Browne's "Account of Birds found in Norfolk," referred to this species-"a small dark grey bird, little bigger than a stint, of fatness beyond any. It comes in May into marshland and other parts and abides not above a month or six weeks," until, in a letter from Sir Thomas to Dr. Merrett* (September 13th, 1688) I found the "Avicula maialis, or Maychit," $\dagger$ further described as "a marsh-bird, the leg's and feet black, without heel; the bill black, and about three-quarters of an inch long," which leaves no doubt that this bird (from its fatness "accounted a dainty dish)" was no other than the sanderling.

I have omitted the Spotted Sandpiper (Totanus macularius, Temm.) from the present List as I have reason to doubt altogether the authority upon which a single example was recorded by Messrs. Gurney and Fisher as lilled at Runton, near Cromer, on the 26th of September, 1839. I am the more desirous also of giving publicity to this fact, since the claim of the Spotted Sandpiper to be included even in the list of British birds, rested solely, for some years, upon the authenticity of this particular bird; $\ddagger$ and though recorded

* Wilkin's edition of Sir 'Thomas Browne's works, vol. i., p. 399.

† No mention is made of this species in the original edition of Merrett's "Pinax," published in 1667. Whether any notice of it is given in that published in 1704. I am unable to say.

$\mp \mathrm{Mr}$. Yarrell, it seems, heard of this bird from the late Mr. Heysham, of Carlisle, who had seen it in Mr. Gurney's collection, $2 \mathrm{H}$ 
by Yarrell ("British Birds," vol. ii., p. 614)* on the authority of the individual who sold it to $\mathrm{Mr}$. J. H. Gurney, I had also the assurance, about three years back, of the late Mr. John Sayer, of this city, that it was a skin when placed in his hands to be stuffed. A statement which I am the more ready to believe from a recent and careful examination of the bird in question.

\section{TOTANUS GLOTTIS (Linnæus).}

\section{GREENSHANK.}

The Greenshank is a regular though by no means numerous visitant to our coast, as a bird of passage, making its appearance with other migrants about the first week in May, and again at the close of the breeding season by the beginning of August. Being an extremely shy species but few specimens are obtained at either season, and these for the most part with the punt gun; and though stragglers are occasionally met with on our inland streams, the tidal channels of Breydon and Blakeney, or the flat sandy shores of the "Wash," between Lynn and Hunstanton, have evidently most attractions for them during their brief stay.

and but for this circumstance would have omitted this species altogether from his List of British birds, believing that the examples figured by Edwards and Bewick were no other than specimens of the common sandpiper. Since that time, however, this American species is said to have occurred in Great Britain, in several instances, but I am glad to learn that Mr. J. H. Gurney, jun., is engaged in sifting the evidence upon which these records have been made, most of which are, I suspect, extremely doubtful.

* This was omitted in the 3rd edition of Yarrell's "British Birds." 
As exceptions to this rule may be mentioned a single bird killed by Mr. Newcome, near the river at Feltwell, during the first week of September, 1860; and another recorded by Mr. T. E. Gunn, in the "Zoologist" (p. 9290), as "shot in a meadow adjoining the river below Hellesdon mills, about three miles north-west of Norwich." This proved to be an adult male. A female killed on the 12th of May, 1864, contained a considerable cluster of eggs, of which some were as large as hempseeds. Mr. F. Harmer, of Yarmouth, in recording* the fact of two pair having been killed on Breydon, in May, 1862, says, "three were killed at a shot with a punt gun, on the flats above mentioned, the other singly; I have killed them two and three at a shot in the same manner, but of late years their numbers have been few during the spring migration; eight is the most I have seen together on the 'muds' at one time." From Mr. Lubbock's account, also, there is little doubt that the greenshank may be considered a scarce visitant now in comparison with former times, as he states that in August " these birds used to frequent the marshes by day, and come down to wash themselves at the gravelly margins of the broad [Hickling] in the evening, when their cry was very singular and melodious." There seems no reason, however, to suppose that this species was at any time a resident in this county, although on more than one occasion eggs resembling those of the greenshank have been found in our marshes. In the "Zoologist" for 1848 (p. 2147) Mr. W. R. Fisher expressed his belief that three eggs then in the collection of Mr. J. Smith, of Yarmouth, and "taken some years since in the Norfolk marshes," were those of the greenshank, having compared them with a

$$
\text { * See "Field," 1862, vol. xix,, p. } 494 .
$$


drawing of a genuine egg of this bird, obtained in Sutherlandshire by Sir W. M. E. Milner.* The general colour and markings of $\mathrm{Mr}$. Smith's eggs agreed with the drawing, although they differed somewhat in form, being "less elongated." But it must be remembered that Sir William's specimen was the result of a Crsarian operation, and had probably not received its full colouring. Indeed, Mr. A. Newton tells me that he also saw the drawing, of which he now possesses a fac simile, and that it was so unlike the normal egg of the species that no correct opinion could possibly be formed from it. Beyond the statement, then, that there appeared to be no other species to which these eggrs could be referred, no satisfactory conclusion was arrived at; and I also remember in 1853 being shown two fresh eggs, said to have been found in the marshes near Yarmouth, which answered very nearly to the description of the eggs of the greenshank as given by Macgillivray. These, I believe, passed into Mr. J. H. Gurney's possession, but were never satisfactorily identified.

Of some dozen examples recorded in my own notes, I find about equal numbers were killed in spring and autumn, the dates at the former period varying between the 8th and 19th of May, and at the latter between the 2nd of August and the 16th of September. $\dagger$ I have never known this bird to appear even as a straggler during the winter months, but Mr. Dowell observed it at Blakeney in 1848, in the early part of October; and in 1853, saw a single bird at the "freshes" as early as the 25 th of July.

* See "Zoologist," 1848, pp. 2014 and 2024.

+ Mr. A. C. Kennedy in "Land and Water" (September 21st, 1867) states that on the 11th of September, 1867, "a fisherman shot three specimens of the greenshank on the river Alde, Aldoburgh, Suffolk." 
Mr. Harting who, under shelter of a sea wall, had on one occasion the rare chance of observing the actions of three greenshanks feeding on a mud-flat, remarks ("Birds of Middlesex," p. 181), "they placed the bill upon the surface, the under mandible almost parallel with the mud, and as they advanced, scooped from side to side after the fashion of the avocet, leaving a curious zigzag line impressed upon the mud." Their food consists of mollusks, insects, and small crustacea.

\section{RECURVIROSTRA AVOCETTA, Linnæus.}

\section{AVOCET.}

When examining a recently killed specimen of the Arocet, so great a prize now a days to the local collector, it seems hard to believe that such a remarkable species should have bred regularly in this county until within the last half century. Yet that this was the case we know from the living testimony of both sportsmen and professional gunners, in whose younger days this bird was comparatively common. Sir Thomas Browne, unfortunately, gives scarcely any information as to the localities frequented by it in his time, merely speaking of the "shoeing-horn" as "a summer marshbird and not unfrequent in Marshland,"* from which, however, one may infer that it was then a denizen of the extreme western side of the county as well as of the coast-line to the north and east. From later authors

* In a letter to Dr. Merrett in 1668 (Wilkin's edition, vol. i., p. 400), Sir Thomas describes this bird as "a shoeing-horn or barker, from the figure of the bill and barking note; a long made bird, of white and blackish colour; fin footed; a marsh bird; and not rare some times of the year in Marshland." 
the only breeding stations of which we have any record, are Winterton and Horsey, and a spot near the Sevenmile House, on the Bure or North River, all in the neighbourhood of Yarmouth, as well as the far-famed Salthouse marshes, near Blakeney, their last haunt in the Eastern Counties.* Messrs. Sheppard and Whitear, from their own observations, wrote in 1824 that "during the breeding season the avocet used to frequent the marshes at Winterton; and in the summer of 1816 we saw one there which had young ;" so that its extinction in that locality, if not actually effected in that year, most probably occurred very shortly after.

At Horsey, as Mr. Rising informs me, they continued to breed certainly as late as 1819 , and probably a year or so longer, but after that time "when the marsh grounds, which had been enclosed, were either converted into arable or were more or less frequented by men and cattle, the birds forsook their liaunts, and they were lost to us altogether." Their nests were placed in the lower parts of the marshes, adjoining the warren, over which the sea had been, and which "retained more or less of the salt left thereby, and where samphire used to grow." A few visited Horsey in the summer of 1824, but did not remain to breed; and since that date $\mathrm{Mr}$. Rising cannot remember having seen above half a dozen specimens, and those merely stragglers on their migratory course. Of the condition of this wild district, prior to the changes effected through embankment and drainage by the late and present owner of the estate, the late Mr. C. S. Girdlestone, of Yarmouth, thus wrote to Mr.

* Pennant says "we have seen them in considerable numbers in the breeding season, near Fossdyke Wash, in Lincolnshire;" and in the history of that county, in Gough's edition of Camden's "Brittannia," I find the following passage-" Opposite Forsdyke Wash, during summer, are vast numbers of avocettas, called there "yelpers' from their cry." 
Selby* in 1821- "Horsey is a most extraordinary place for all sorts of wild birds, though nothing as good as it was ten years ago. It is a desolate spot, and duty at church is performed only once a month, and in winter this place is scarcely approachable." In the same letter, also, the avocet or "shoe-awl," is described as still breeding there, but, as shown before, reclamation had already banished them with other contemporary species, whose numbers had been slowly but surely diminished by other and less justifiable causes. Mr. Lubbock, in 184.5, speaking of the numbers of this species that formerly bred at Horsey, remarks that it "has not done so of late years," $\dagger$ but adds, "on the authority of an old and respectable fen-man, it bred regularly forty years ago near the Seven-mile House, on the North River; occurs still sometimes on Breedon. The last I know of positively in the fens, was a small flock which visited Sutton broad in 1828." As at the present day only stragglers, or at most a pair or two, are ever seen on our coast at one time, it is not improbable that the small flock here mentioned reappeared in that neighbourhood with some intention of resuming their old quarters, if undisturbed; and we may conclude, therefore, that they had altogether ceased to breed in the "Broad" district, some time between the years 1824 and 1828. It seems

* For the privilege of extracting this and other passages on Norfolk ornithology, from the correspondence of the late Mr. Selby, I am indebted to the kindness of his daughter Mrs. Antrobus, at the solicitation of my friend Mr. Alfred Newton.

+ Mr. Lubbock also refers to a communication by the Rev. E. Ventris, of Cambridge, to the "Magazine of Natural History" for 1836 , in which the writer states that he had been recently informed that the egret " annually visited Horsey, in Norfolk, till about twelre years ago, and that since that time it has disappeared." 'This unquestionably was a mistake, the arocet and not the egret being intended, as before shown (p. 150) in my remarks on that rare visitant. 
probable, also, that two out of the three stations above mentioned, from their propinquity to one another, consisted, as is the case with our heronries, of small branch establishments from one parent colony, and that, no doubt, centred at Horsey.

At Salthouse, long prior to the drainage of the marshes and the erection of a raised sea-bank, the arocets had become exterminated by the same wanton destruction of both birds and eggs as is yearly diminishing the numbers of lesser terns and ringed plover on the adjacent beach. I have conversed with an octogenarian fowler and marshman named Piggott, who remembered the "clinkers" (as the avocet was there called), breeding in the marshes "by hundreds," and used constantly to gather their eggs.* Mr. Dowell, also, was informed by the late Harry Overton, a well known gunner, in that neighbourhood, that in his young time he used to gather the avocet's eggs, filling his cap, coat pockets, and even his stockings; and the poor people thereabouts made puddings and pancakes of them. The birds were also as recklessly destroyed, for the gunners, to unload their punt guns, would sometimes fire at and kill ten or twelve at a shot. $\dagger$ No wonder, then, if the avocets thus constantly persecuted gradually became scarce. It is stated, moreover, by Mr. Lubbock that their feathers were much sought after to make artificial flies. Here as in the previous instances, at Horsey and Winterton, it is difficult to fix the exact

* The egg figured by Hewitson ("Eggs of British Birds," 3rd edition, vol. ii.) from the late Mr. Salmon's collection, "was obtained by him in Norfolk, where he had no doubt it was laid."

+ Some of these, probably, found their way into the London Market, as Yarrell, speaking of the rarity of the arocet, says, "Some years ago I was told that more than twenty specimens were received at Leadenhall Market for sale within one month, but now scarcely an example appears in a year." 
date of extinction, but it is probable from the following particulars kindly communicated by $\mathrm{Mr}$. W. J. Cubitt, of this city, that it occurred between 1822 and 1825, as he remembers, about that time, visiting Salthouse, in summer, with Mr. Jary, of South Walsham, when two or three couples were shot, and a boy waded through the swamp and brought out a young bird. A single bird was left, which he understood was seen there for some time after, but he fears that this expedition saw the last of the avocets. They bred on the saltmarshes, subject to constant inundations from the sea, beyond the shingly beach, and consequently the ground was full of holes and soft places, which rendered it difficult to reach their breeding sites. From the records of specimens killed subsequently to that date, at Salthouse, it seems that until those marshes were altogether reclaimed in 1851, stragglers from time to time still visited their old haunt, on their migratory passage; but of late the few that have appeared on our coast have been met with either on Breydon or in the neighbourhood of Lynn. In Sir William Hooker's MS. one is said to have been shot at Palling, near Yarmouth, on the 3rd of May, 1831; and in the same year, as Mr. Joseph Clarke informs me, three were killed at Salthouse of which two are now in the Saffron Walden Museum.

In the "Zoologist" for 1843 (pp. 148 and 182), Mr. W. R. Fisher records two examples as killed on Breydon in May and July, 1842; and on the 28th of March, 1843, a female was also shot on Breydon, and two others were subsequently seen on the same "muds," of which one was killed. Of the first of these, which was only wounded in the wing, and ran very swiftly when pursued, Mr. Fisher states that "the gizzard contained some of the small black beetles which abound in the mud banks of the river, and what appeared 
to be remains of shrimps, mixed with a good deal of gravel."

In 1846 Mr. Dowell had a specimen brought him by a gunner named Moy, from Salthouse, described as "the first that had been seen there for some years." $\mathrm{He}$ also states that another was shot at Salthouse, on the 26th of April, 1847, by the same man; and in the Dennis collection, at Bury, is an adult bird from the same locality, marked June, 1847.

1848. September 7th. Three females shot at Salthouse. ("Zoologist," p. 2292).

1849. April. One seen near Lynn, during this month. ("Zoologist," p. 2455).

1851. June. Two fine specimens killed at Yarmouth. ("Zoologist," p. 3208).

1852. May 2nd. A pair shot on Breydon. In the "Naturalist" for this year (p. 128), a pair are also recorded as killed at Yarmouth on the 12th of June.

1853. April (?). An adult male in the Dennis collection, at Bury, was procured in the spring of this year at Yarmouth.

1857. April. A single bird was shot at Yarmouth about the 22 nd.

1863. May. Two or three seen on Breydon.

1864. May. One killed at Yarmouth.

1865. May. Two shot at Yarmouth, and sent up to London for sale.

1867. Of three killed on the sands of the estuary, at Lynn, in the spring of this year, one is now in the Museum of that town, and a pair in the collection of Mr. H. Upcher, of Sherringham.

In Mr. Gurney's collection are three specimens killed in Norfolk, and Mr. Newcome has a pair in his collection at Feltwell; but although I cannot ascertain the exact dates, I believe they were procured some twenty years ago, and are probably all of them included in the above list. 
It must not be supposed that because my notes contain no record of examples seen or lilled from 1853 to 1857 , and again from 1857 to 1863 , that therefore none appeared on our coasts during those periods, but undoubtedly they must have been searce; and this species can only be regarded now as an irregular migrant. Of such as I have been able to ascertain the exact dates, it will be seen that only three were obtained in autumn (September), the remainder in spring and summer, between March and July, but chiefly in the month of May.

It is much to be regretted that our earlier local authors afford us so little information as to the habits of this most interesting bird-whether for instance, like the terns, ruffs, and redshanks, they were summer visitants only, or, leaving their breeding grounds when the young were able to $\mathrm{fly}$, spent the winter months on the coast, at the mouths of our tidal rivers. The avocet, however, is specially mentioned in Ray's edition of Willughby's "Ornithology," as frequenting "our eastern coasts in Suffolk and Norfolk in winter time." The bird observed by Messrs. Sheppard and Whitear, at Winterton, in 1816, is said to have flown round in circles "uttering a shrill note [twit, twit], and then alighted in the middle of a pool of water, on which it floated; then took several turns on wing, and again alighted on the water, where it sat motionless."

It has been questioned by many writers whether these birds are really able to swim, but on this point I can quote a high authority, Mr. Osbert Salvin, who, in his notes "On the Sea-birds and Waders of the Pacific coast of Guatemala" ("Tbis," 1865, p. 193), says of the American species (Recurvirostra americana) "arocets often swim;" and with their semi-palmated feet, so admirably adapted for traversing the most treacherous swamps, there seems no possible reason 2 I 2 
why they should not possess natatorial powers to a certain extent. The eggs, generally two in number but never more than three, are laid in a slight hollow on the bare ground, or on a scanty lining of grasses, and their method of procuring food has acquired for this species the name of the "scooping" avocet, as they feed in line like mowers, leaving, as stated by Pennant, "alternate semicircular marks on the sand to mark their progress;" somewhat after the manner of the spoonbill and greenshank, but with this exception, as stated by Mr. Knox ("Zoologist," 1843, p. 227), "that the avocet ploughs with the convexity of the bill." He also states that a wounded bird, when turned loose in a garden, exhibited the action of "ploughing or mowing from right to left along the surface of the grass, or rather brushing it from side to side." Their food is said to consist of worms, insects, and small thin-skinned crustacea.

\section{HIMANTOPUS MELANOPTERUS, Temm.}

\section{BLACK-WINGED STILT.}

This rare species has occurred in Norfolk, as an accidental visitant, in several well authenticated instances; and I have, therefore, taken some pains to trace out the history of such specimens as have been noticed from time to time in our local records.

Messrs. Sheppard and Whitear did not include this bird in their "List," published in 1824; but in Mr. Lombe's MS. notes, I find mention of one killed in Northwold Fen, in June, 1822, on the western side of the county; and a pair are stated by Messrs. Paget to have been shot on Hickling Broad during the same 
year. Of one of these, which was shot by himself, Mr. Lubbock communicated the following interesting particulars to Yarrell's "British Birds" :- "On the 9th of June, 1822, I was returning in the evening from fishing upon Hickling Broad, when a bird of this species flew past the boat within thirty yards. The legs were extended behind, even more in proportion than those of a heron; the wings were much arched; the flight vigorous and regular; the colour and the length of limb made me guess what it must be. I asked the fenman who was with me, what he gruessed it to be? He considered it a ruff which had been caught, as is sometimes the case in our marshes, by a horse-hair snare, and had broken away with it. When I told him that I believed it to be a very rare and valuable bird, he wished to go in immediate pursuit, but I overruled that, as there was not more than half-an-hour's light remaining, and the bird, if shot at ineffectually, might leave the country in the night. We searched for it early the next morning, and found it in precisely the same place as the evening before. When shot* it was standing in a shallow pool of water, mid-leg deep, apparently snapping at insects in the air as they buzzed round it." $\dagger$

* This bird, which is also noticed in Hunt's "List," was presented by Mr. Lubbock to Mr. J. Postle, of Colney, who was then a collector, and at his death it came into the hands of his son, tho late Rev. Edward Postle, of Yelverton, and is now in the possession of Mr. Henry Postle, of Little Witchingham.

† In Mr. Salvin's "Five months' birds' nesting in the Eastern Atlas" ("Ibis," 1859, p. 360) this species is described as breeding in the marshes of Zana and Chot Saboun "in great abundance amongst the wet grass, choosing for the position of its nest a small tuft, so as just to keep the eggs out of the water." In some cases, however, the eggs were half immersed. At the moment of taking flight, the long legs of this bird hang awkwardly down, but once fairly on the wing they are stretched out far beyond the tail; and when striding about in search of food their movements are not 
In Mr. E. S. Preston's possession at Yarmouth is a specimen formerly belonging to his uncle Mr. C. Preston, of that town, which was shot on Breydon in May, 1823, by old John Thomas, a noted gunner on those waters; the same bird referred to by the late Mr. Hoy, in a letter to Selby, as published by Dr. Bree in the "Field" (vol. xxx., p. 385), in that gentleman's description of $\mathrm{Mr}$. Hoy's collection at Stoke Nayland.

Again in 1824, according to the Messrs. Paget, another was shot "two miles up the North river" (Bure), which, at the time their "Sketch" was published, was said to be in Mrs. Baker's collection.* In all probability this was the same bird which, as $\mathrm{Mr}$. Rising informs me, made its appearance at Horsey, for one day only, in the summer of 1824, and escaped uninjured. It is also, I imagine, the same which is thus incidentally referred to by Yarrell-" My own specimen, from which the figure and description here given was derived, was obtained in the London market in July, 1824, and was sent up for sale from Lincolnshire; while this bird was in the hands of Mr. Leadbeater for preservation, another was received from Norfoll. In the intestines of this last specimen, which I examined, was a species of tape-worm six inches in length, broad, flat, and jointed." It is also stated by Yarrell, on the authority of Mr. Lubbock, that "a pair were shot by Mr. Salmon, at Stoke Ferry, in the spring

ungraceful. The young stilt, he says, "is able to walk almost immediately on leaving the egg; one we found was capable of moving about, while the other three were struggling to free themselves from the shell. The nest is composed of a few bits of dead reed or grass. The complement of eggs laid by one bird is four."

* This is no doubt the specimen mentioned by Hunt in 1829 , as in Mr. C. S. Girdlestone's collection at Yarmouth, which passed into the hands of his sister Mrs. John Baker. 
of 1826 ; the female had eggs within her in a forward state," as was the case, as Mr. Lubbock states in his "Fauna," with one of those killed near Yarmouth. One of Mr. Salmon's birds is still preserved in $\mathrm{Mr}$. Lombe's fine collection at Wymondham, together with another specimen (marked male and female in the catalogue), which it is possible may be the one recorded in his MS. notes as killed in Northwold Fen.

Another example appears to have been seen, but not killed, at Yarmouth, in 1839, as shown by the following extract from a letter to Mr. H. Doubledily, of Epping, from the late Mr. Heysham, of Carlisle, (dated September 15th, 1839), for which I am indebted to $\mathrm{Mr}$. J. H. Gurney, jun.:- "'From a letter which I received a day or two ago, from a friend in Norfolk, I find that a specimen of the black-winged longshank was lately seen on Breydon, which, however, I understand, escaped."

In Mr. J. H. Gurney's collection is a female shot near Yarmouth, about the 7th of May, 1842, as recorded by Mr. W. R. Fisher in the "Zoologist" (p. 182); and in the "Annals of Natural History," (vol. ix., p. 353), the same is stated by Mr. Gurney to have been killed at Hickling, "apparently a bird of last year" and a female, containing ova of about the size of a shot." This is the last that I know of as having been actually killed in this county; but a bird of this species was seen at Yarmouth on the 19th of May, 1866, a rather remarkable season for rare birds on their spring migration. It was observed on the beach, as $\mathrm{Mr}$. F. Frere informs me, with other birds, whilst the artillery were practising their big guns, and being thus disturbed at the time, it was followed up by a gunner as far as Caister, where he made a long shot at and missed it, and it was not heard of again.

Mr. Newcome, of Feltwell, has a Norfolk-killed specimen, which he purchased in 1853, at the sale of 
Mr. Miller's collection at Yarmouth. This may be either one of those killed at Hickling in 1822, or, which is quite as likely, Mrs. Baker's bird of 1824. All but one of the above examples seem to have appeared during the summer months between May, June, and July. In the Dennis collection at Bury, I also found a bird of this species, described as shot at Orford, but date and sex unrecorded.

\section{IMIOSA IIELANURA，Leister.}

\section{BLACK-TAILED GODWIT.}

The Black-tailed Godwit is another of those grallatorial birds which, within the last half century only, have ceased from breeding in our marshes. It were needless here to repeat the "twice told tale" of its extinction, the same causes having effected the same end in this as in many other cases, but I have thought it desirable to ascertain as nearly as possible, from contemporary evidence, the date when this fine species ceased to nest in Norfolk.

"Five species in particular," wrote Mr. Lubbock in 1845, "used formerly to swarm in our marshes,the godwit, the ruff, the lapwing, the redshank, and the black tern. * * * * Whilst the redshank, in the breeding season, flew dashing around the head of the intruder on his territories, and endeavoured like the lapwing to mislead the stranger from the nest, higher in the air, and flying in bolder circles uttering a louder note, was the black-tailed godwit, called provincially the "shrieker" from its piercing cries. This bird is now almost extinct in this part of Norfolk; it used to breed at Buckenham, Thyrne, 
Horsey, and one or two other places." Mr. Lubbock evidently wrote guardedly as to their extinction, probably not having the opportunity at that time to ascertain the fact conclusively, but there is no question that prior to the date of his "Fauna" this species had become, what it is now in this county, an irregular migrant only. As far back as 1825,* we have the following statement of Messrs. Sheppard and Whitear: "Some of these birds used to breed in the marshes of Norfolk, and three years since we received the egg of this species from Yarmouth. But it is doubtful whether they are to be found at present in their former haunts." This doubt I can now satisfactorily clear up, on the authority of Mr. Rising, of Horsey, who remembers a godwit's nest in that neighbourhood in the summer of 1829, and thinks it quite possible that these birds may have bred there some few years later, but for the next ten years, being invariably engaged in London during the spring months, he had no means of satisfying himself on this point, although greatly interested in the subject. If we assume, then, that in yearly decreasing numbers they still frequented certain favourite localities for a few seasons longer, their extinction may, I think, be said to have occurred somewhere between the years 1829 and 1835. It seems probable, however, that during the next twenty years a pair or two occasionally returned to their old haunts $\dagger$

* In 1824 the late Mr. C. S. Girdlestone wrote to Mr. Selby, "I am informed the red godwits breed in some marshes ten miles from hence [Yarmouth], but I cannot speak to the fact; but this I know, we had some here about the 20th of June last season, and my bird-stuffer says he has had them in all the summer months, and he is a man of veracity."

† As the hen harrier and Montagu's harrier, now no longer resident, are known to do from time to time. 
in the spring, though only to be robbed of their eggs, or shot down from their rarity, as I have heard of such occurrences from two or three different sources. Mr. Gurney remembers, some thirty years ago, being informed that a pair or so of black-tailed godwits still resorted at times to Sir William Beauchamp Proctor's marshes, near Buckenham Ferry. This species, also, as Mr. Gurney remarks, was formerly an abundant breeder in Holland, but like the purple heron, spoonbill, and little bittern has been so destroyed there of late years, that it has become comparatively rare; and this fact would also in some degree account for its scarcity on the East coast of England.

In the Catalogue of Mr. E. S. Preston's collection of eggs, which was sold at Steven's, 23rd March, 1858, "Lot 95" consisted of "three black-tailed godwits, Reedham, Norfolk, 1857." Two of these specimens are now in Mr. A. Newton's collection, who was assured by Mr. Preston that the above description of the eggs was correct, and that they had been taken in Norfolk.

Mr. A. Newton has also an egg of this bird, given to him by Mr. O. Salvin, who obtained it from a friend of his, Mr. J. King, late of Trinity Hall, Cambridge. This example was bought by Mr. King, in 1847, in the Cambridge market of a countryman, who had also a young short-eared owl alive-and there can be little doubt that both bird and egg had been taken in this country.

In the western fens these birds are known only by tradition as former residents; but amongst the strange incidents of the "great flood" of 1852, was the appearance in that neighbourhood during the following spring of this godwit amongst other species, once denizens of that wild district, but unknown there for years. Mr. Newcome's collection contains a pair killed there at that time. A pair in Mr. Gurney's collection, in full summer plumage, were shot in this county many years back; 
and two specimens in my own possession, one in summer and the other in winter plumage, were also, I believe, killed in Norfolk before they had ceased to nest here.

As before stated, the black-tailed godwit now holds a place in our List as an irregular migrant only, visiting us in small numbers both in spring and autumn. Prior to the drainage of the Salthouse marshes they were occasionally seen in that neighbourhood, but Mr. Dowell describes them as rare at Blakeney, and the few specimens obtained are mostly procured on Breydon.

In the "Zoologist" for 1847 (p. 1785) is the following note by Messrs. Gurney and Fisher:-_66 On the 7th (May) a pair of black-tailed godwits (male and female) having partially assumed the summer plumage, occurred at Salthouse." Another is also stated ("Zoologist," p. 1956) to have been killed at the same place, in September of that year. The following are all the examples of which I find any record in my own notes:-

1851. April. A single bird, killed at Blakeney.

1854. May 2nd. A fine bird in full summer plumage, shot at Hickling.

1859. May. A female in full summer plumage, killed at Yarmouth. In Captain Longe's collection.

1860. September 7th. An immature bird, shot at Blakeney.

1862. August. A pair of immature birds, killed on Breydon.

1863. August 22nd. An immature bird, killed at Yarmouth. In the collection of the Rev. C. J. Lucas, of Burgh.

1864. August 27th. Four fine immature birds, said to have been killed at Yarmouth, were exhibited for sale in the Norwich market, one of which is now in my own collection.

1866. January 10th. An adult bird, shot at Yarmouth during very sharp weather.

2 к 2 
Even in this short list of specimens, the young birds of the year, obtained in August and September, are the most numerous; $*$ and although I have heard of their being seen occasionally in winter in the neighbourhood of Lynn, I do not imagine that they are more numerous at that season than in either spring or autumn.

Mr. Rising informs me that their cries, when disturbed in the marshes, very closely resembled the mewing of a cat.

Both by Ray and Pennant, and amongst later authors by Bewick and Montagu, the name of yarwhelp or yarwhip is associated with this species, and it is no doubt the same to which Sir Thomas Brownet refers in a letter to Dr. Merrettł [December 29th, 1668], in which he asks, "have you a yarwhelp, $\S$ barker, or latrator, a marsh bird about the bigness of a godwitt?" and in his general list of species he remarks- "Godwyts, taken chiefly in Marsh-land; though other parts are not without them; accounted the daintiest dish in England; and, I think, for the bigness of the biggest price." In support of this statement, it may be mentioned that Pennant describes them as "taken in the fens, in the same season, with ruffs and reeves, and when fattened

* Even prior to their extinction in Norfolk, Messrs. Sheppard and Whitear speak of a large flock of these birds which appeared at Yarmouth in October, 1819.

+ Wilkin's edition of his works, vol i., p. 403.

\$ Merrett in his "Pinax" (1667), includes (p. 173) "Attagen, a Godrvit * * * in agro-Iincoln ;" but his reference to a plate of Jonston's "Theatrum universale de Avibus," wherein is figured, under the former name, the hazel grouse (Tetrao bonasia) shows that at that time the idea of a godwit was not very well defined among book-naturalists.

$\S$ “Whelp Moor," near Lakenheath, probably derived its name from this species. 
are esteemed a great delicacy, and sell for half-a-crown or five shillings a piece." In the Lord North Accounts, is a single entry of two "yerwhelps" supplied at two shillings.

\section{LIMI OSA RUFA, Temminck.}

\section{BAR-TAILED GODWIT.}

Whilst the previous species has become scarce, even as a migrant, the Bar-tailed Godwit may be reckoned as the type of our migratory waders. Regular, and in. favourable seasons abundant, on its spring and autumn passage, there still seems no reason to suppose that this species was at any time a resident in our marshes; though doubtless a still more numerous visitant in former days, when the country presented far greater attractions, and the persecutions of local gunners had not as yet thinned their ranks, or warned them to "pass on" quickly to their distant homes.

In spring a few specimens are occasionally obtained as early as the first or second week in April, either pioneer's of the main body of migrants, or birds which have scarcely left our shores throughout the winter; yet even amongst these, I have occasionally noticed one or two males which had assumed the rich red of their breeding plumage. It is not, however, till the month of May that the northward movement takes place in earnest, and so constant is the date of their vernal passage, that the 12th of May is known as "Godwit day" to the Breydon gunners. Such, at least, from the observations of many seasons, is the average time of their appearance, though from the commencement of that month up to the 20 th or 21 st examples are met with in every variety of plumage, as flight follows flight, impelled by instinc- 
tive warnings to hurry onwards to their northern breeding grounds. But though thus passing over us with a marvellous regularity, it is not every season that affords a harvest to the gunners. A cold backward spring, with a long succession of north-east winds, will so delay the passage of these birds, as well as many other migrants, that with the first favourable change they press forward almost unnoticed, resting scarcely for a night to recruit their strength. On the other hand, with a prevalence of south-west winds, at the appointed time, and more particularly, I am told, if accompanied by a light drizzling rain, the "muds" of Breydon and Blakeney are alike gay with their many tinted groups, and the records in my own notes of the numbers killed at such times, not of godwits only, but of knots, sanderlings, turnstones, and such like, within the space of a few days, fully proves the effect of these atmospherical influences.

Such a season was that of 1855, and even more remarkable that of 1866, when, through the kindness of my friend $\mathrm{Mr}$. F. Frere, of Yarmouth, I had. the opportunity of dissecting some eighteen or twenty bar-tailed godwits, all procured on Breydon, and satisfying myself as to the relative proportions of males and females, and the intensity or otherwise of the colouring of both sexes in their nuptial dress. Of this interesting series I have now fifteen slins in my own possession, from which the following notes have been made, and as the chance of taking accurate measurements in the flesh from so many examples but rarely occurs, I believe many of my readers will be interested in the result of my examinations.

On the 7th of May I received two remarkably fine birds, which had probably been selected from their rich colouring, both of which proved to be males :-

No. 1. Male, adult. All the under surface of the plumage 
from the chin to the vent, bright chesnut red, with only a few white feathers showing on the lower parts of the body. The feathers on the back also edged with rufous, but the wing-coverts as yet but little changed.

No. 2. Male, adult. An almost exact counterpart of the previous specimen, but having a few more rufous feathers in the wing-coverts.

Of half a dozen killed on the 16 th of May,--five males and one female,-the variation in plumage may be thus described :-

No. 1. Male, immature. In a state of half change, with white feathers sprinkled amongst the red on the breast and vent, and the red of the neck, breast, and flanks, streaked and barred with black, which in older birds, at that season, is almost entirely absent.

No. 2. Male, immature. Rather more mottled, with white and black on the under parts, but the red tints very rich in colour, and the testes somewhat larger than in the previous specimen.

No. 3. Male, adult. In magnificent plumage; nearly all the feathers of the wing coverts margined with reddish brown, and the whole of the under surface of the body one uniform rich chesnut.

No.4. Female. In winter plumage with the exception only of two or three red feathers appearing on the back and throat. Feathers of the wing coverts and tertials much worn at the edges. The ovary contained some eggs about the size of No. 6 shot.

No. 5. Male, immature [?]. A very abnormal specimen, which, but for the evidence of dissection, I should have judged at once to be a young female, the bill measuring within 2-8ths of an inch, of the aize of most females, whilst the other measurements are barely those of adult males. With the exception of a few minute freckles of red on the chin, this bird is in complete winter plumage, the feathers of the wing coverts and tertials being much worn, in some only the shafts remaining towards the anterior portion of the feathers. The testes were small, but still quite distinguishable.

No. 6. Male, adult. In exactly similar plumage to the two killed on the 7 th.

Three more specimens obtained on the 17th of May, two males and one female, presented the following differences of plumage :-

No. 1. Male, adult. Exactly resembling the two killed on tho 7th. 
No. 2. Male, immature. Resembling No. 1. killed on the 16th, but with ferwer black markings on the breast and flanks.

No. 3. Female. The chin, neck, breast, and flanks suffused with reddish tints, mixed with dull white, and streaked and barred with dusky brown, a state of plumage much resembling the female sanderling at the same period. The lower part of the breast and vent still pure white, with a few dark bars and reddish feathers showing here and there. Wing coverts still grey, but the feathers of the head, neck, and back gradually acquiring their reddish margins. Ovary full of eggs, but none larger than dust-shot. Three other birds of the same size, killed at the same time, and in somewhat similar plumage, proved to be females.

Of the last series killed, on the 19th of May, two proved to be males and two females:-

No. 1. Male, adult. Similar to the two killed on the 7th of May, very rich in the colour of the neck and breast, but with only a few reddish feathers appearing in the wing coverts.

No. 2. Female. The change to summer plumage only just commencing. The under parts slightly tinged with red on the neck and breast, but the dark streaks and bars very prominent. Only a few feathers on the lower part of the back have reddish margins. The ovary contained some eggs about the size of No. 4 shot.

No. 3. Female. In much the same plumage as the last, but the red on the breast and flanks rather more vivid. Some of the eggs about the size of No. 4 shot.

No. 4. Male. Plumage resembling No. 6, killed on the 16th but having more white feathers still showing on the lower part of the back and breast.

From a comparison, of the above specimens, it is evident that the same rule applies to this species as to the sanderlings in the gradual assumption of their nesting plumage, but the female godwit* never assimilates so nearly in colour to the male, as is the case with

* Mr. Alfred Newton informs me that the female godwits which he has had from Lapland, some of them killed from the nest, have never been very red, but in that pale plumage which was described by Leisler (Nachträge, p. 172) as characteristic of the so-called Limosa meyeri. 
the adult female sanderling, which, as I have before stated, is distinguishable only by dissection in some instances.

The old males evidently commence their change much earlier than the young birds of the previous season, as I have handled one in nearly full summer plumage by the 1st of April; and the two killed on the 7 th of May, 1866,* were very nearly as perfect as the exceptionally fine male shot on the 16 th. In all cases the full red birds that I examined had the testes largely developed, whilst the same parts in the males with broken plumage were invariably small.

The great difference in size between the male and female godwits was at one time supposed to denote a specific distinction, $\uparrow$ but whilst we now know that the largest are always females and the smallest males, $\ddagger$ both

* In the "Field" of May 26th, 1866 (p. 445), Mr. F. Hele, of Aldeburgh, states that on the 14th several flights of bar-tailed godwits appeared about Thorpe mere and river. Such an occurrence had not been known since 1860, although a few appear every spring. The difference in weight between males and females he describes as remarkable; "in one case being in the male only six and a half ounces, whilst the female weighed one drachm over ton and a half ounces."

+ See Colonel Hawker's "Instructions to Young Sportsmen." Eleventh edition, p. 232.

† Thompson, in his "Birds of Ireland" (vol. ii., p. 229), after stating that of seven birds killed at the same time on the 6th of March, "the small ones proved to be males and the large ones females," says "the bills of the latter, from forehead to point, were from four to four and a quarter inches long," which is in excess of all but one of my own specimens. He also adds, "others which I have killed exceeded four and a half inches; a young bird of the year, obtained on the 24th of August, had a bill only two inches in length [less than the smallest male in $\mathrm{my}$ series]. At the end of October I once shot a godwit of little more than half the ordinary weight, and hardly exceeding a grey plover in size." All proving the extraordinary variation in tho proportions of both sexes. 
also differ much inter se; and occasionally, as -will be seen by the subjoined tables, a female with an unusually short bill, and a male with an exceptionally long one, may entirely mislead the too credulous ornithologist who relies upon external features only.

FEMALES.

* Wingth Middlo

inch. inch. inch. inch. inch.

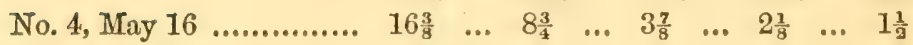

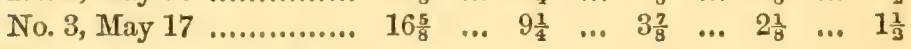

Not in my series, but)

killed May 17th. Red $\} \begin{array}{lllllllll}16 & \ldots & 8 \frac{5}{8} & \ldots & 3 \frac{7}{8} & \ldots & 2 \frac{1}{8} & \ldots & 1 \frac{1}{2}\end{array}$

tinge just commencing

$\begin{array}{lllllllllll}\text { Ditto, ditto } & \ldots \ldots \ldots \ldots \ldots \ldots \ldots & 16 \frac{5}{8} & \ldots & 8 \frac{7}{8} & \ldots & 3 \frac{7}{8} & \ldots & 2 & \ldots & 1 \frac{1}{2}\end{array}$

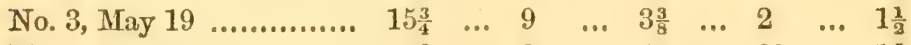

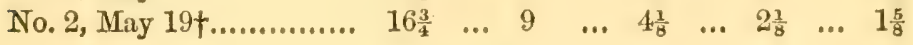

MALES.

No. 1, May 7

$\begin{array}{llllllllll}14 \frac{1}{2} & \ldots & 8 \frac{1}{4} & \ldots & 3 \frac{1}{8} & \ldots & 2 & \ldots & 1 \frac{1}{2}\end{array}$

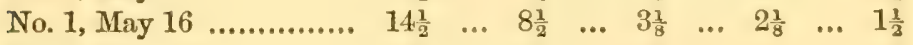

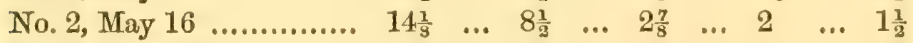

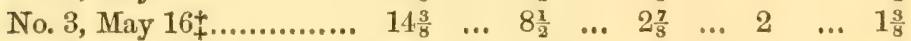

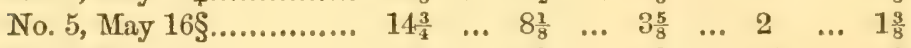

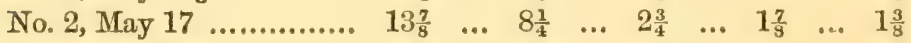

No. 1, May $19 \begin{array}{lllllllllll} & \ldots . . . . . . . & 14 \frac{1}{8} & \ldots & 8 \frac{1}{2} & \ldots & 3 \frac{1}{8} & \ldots & 2 & \ldots & 1 \frac{1}{2}\end{array}$

* Total length from tip of bill to end of tail. Wing, from carpal joint to end of longest quill (first). Bill, measured along the upper mandible.

The numbers and dates are those of each specimen as given in describing the plumage, and correspond with the numbers and dates on the label attached to each bird for convenience of futuro reference.

+ The difference in length between this bird and the previous one is owing chiefly to the size of the bill, which in No. 3 is also exceptionally short.

¥ The most perfect in plumage of all the male birds.

$\S$ The male before mentioned as backward in plumage, and unusually long in the bill, which accounts for the excess in the total length; the other measurements are rather under the average. 
In their spring migration these birds are not entirely confined to the vicinity of the sea-coast, as, on the 10th of May, 1858, two males and two females were observed by the Rev. T. J. Blofeld on a drained marsh at Hoveton, and one pair remained long enough for him to examine them carefully with a glass, the female approaching within shot. A pair were also seen by him, on the same marsh, on the 9th of May, 1861, which seemed so tame, being unmolested, that he began to hope they might remain to breed, but after the third day they disappeared altogether. I may here also add that, differing from almost all our migratory waders, I have never known stragglers of this species killed during the months of June and July; but their reappearance early in autumn is a matter of common observation.

Messrs. Sheppard and Whitear have recorded one, killed in the beginning of August, as still retaining the full summer plumage, and I have seen similar specimens about the same date. On the 13th of September, 1865, I saw four or five couples in the Norwich market, of which one had scarcely commenced its autumnal change, and the rest retained much of their summer garb; which agrees with Mr. Dowell's experience at Blakeney, who says that in August, September, and October, small flocks are found frequenting the Blakeney harbour, and are for the most part very tame, feeding up to within a few yards of one's feet when quietly watching them. Some of these in September were still slightly redbreasted, but a bird shot on the 5th of October had completed its winter grey.

During the winter months a few pairs still linger about our shores, and are met with even during the sharpest weather. In January, 1847, Mr. Dowell had several brought to him in winter plumage by a Blakeney gunner, and has seen stragglers himself in Blakeney harbour, during the same month. From my own notes 2 L 2 
I find that a pair were shot at Wells in 1856, on the 21st of November, and two more at Yarmouth on December 16th. Again on the 12th of January, 1862, three specimens were sent up to Norwich from Sheringham beach with snow-buntings, knots, dunlins, and a purple sandpiper; and on the 26th of May, 1862, during a severe frost, several couples were exhibited for sale, with other birds, in the Norwich market. On the 8th of January, 1867, a male bar-tailed godwit was taken in a meadow near Reepham, as $\mathrm{Mr}$. F. Norgate informs me, most probably carried thus far inland by a heavy gale at the time.

$\mathrm{Mr}$. Harting describes the note of this bird as resembling the words "lou-ey, lou-ey."

I never remember to have heard the name of "Halfcurlew" applied to this species on the Norfolk coast, as stated by Mr. Johns in his "British Birds in their Haunts," being a term here commonly and more appropriately used for the whimbrel, but at Blakeney $\mathrm{Mr}$. Dowell states that bar-tailed godwits are known to the local gunners by the singular appellation of "Picks" and "Scamells." These words are of course written down phonetically, but whence their derivation I am at a loss to conceive. He believes by "Scamells" are meant the females and those found singly in autumn; and by "Picks," the smaller males most abundant in the spring flocks. He further suggests that the word "Picks" may possibly have originated from their manner of feeding, as the turnstone in the same locality is termed the "Tangle picker"; but the definition of "Scamells" I must leave to the ingenuity and research of the indefatigable editor of "The East Anglian."

On the Sussex coast this same species is known as the "sea woodcock," and Mr. J. H. Gurney, jun., assures me that a Pagham gunner once pointed out to him a godwit on the wing, and maintained his assertion that it was a roodcock. 


\section{MACHETES PUGNAX (Linnæus).}

\section{RUFF oR (FEMALE) REEVE.}

Whilst lamenting the absence from our marshes in summer of the avocet, the black-tailed godwit, and the black tern, it is remarkable that the Ruff, with all its peculiarities of action and plumage, should still remain with us during the breeding season. Norfolk, also, as far as I can ascertain, is now the last resort of this species in the Eastern Counties. Pennant described it as frequenting in his time various localities in Lincolnshire, the Isle of Ely, and the East Riding of Yorkshire, but Colonel Montagu, * when making a tour in Lincolnshire, with special reference to this species, at the commencement of the present century, found "that they were become much more scarce than they were before a large tract of the fens was drained and enclosed;" and both in that county and in Suffolk, I believe, they are now extinct, except as passing migrants. $\dagger$

In this county, in former times, not only the marshy portions of the "Broad" district but also the western Fens, appear to have been frequented by these birds in considerable numbers, for Sir Thomas Browne remarks "they most abound in Marshland, but are also in good numbers in the marshes between Norwich and Yarmouth." From Mr. Alfred Newton's enquiries some few years since, there is no doubt that they were

* See the "Supplement" to Montagu's "Ornithological Dictionary," published in 1813.

+ Mr. A. G. More, in his paper on the "Distribution of Birds in Great Britain during the nesting senson" ("Ibis," 1865, p. 437), speaks of the ruff as having ceased from breeding in Durham and Yorkshire, in Huntingdon, Cambridge, Northampton, and "probably also in Lincolnshire," and gives only East Norfolk as an anuual breeding site, with Northumberland " occasionally." 
plentiful enough in the Hockwold and Feltwell Fens between twenty and thirty years ago, until banished, with other species, by extensive drainage, and my friend Mr. Roberts, who for many years practised as a surgeon in that neighbourhood, assures me that he has seen ruffs in the spring fighting in the Feltwell Fens. Even now, should the autumn prove more than usually wet, a few will occasionally frequent the "washes" for a time, as occurred about two years since, when $\mathrm{Mr}$. Newcome obtained several specimens of both ruffs and reeves; and in the spring of 1853 , after the "great flood," this species with other former denizens again resorted to the fens thus temporarily restored to their normal condition.

On the eastern side of the county, as far as one can ascertain from our local records, they appear to have been very generally distributed, more particularly in the centre of the "Broad" district, bordering upon the banks of the Bure and its tributaries; and in the valley of the Yare (in the very same locality above cited from Sir Thomas Browne's notes), the ruff was described as "common" by the Messrs. Paget in 1834, "especially at Reedham and Acle." A very beautiful series of ruffs, in the collection of $\mathrm{Mr}$. Spalding, of Westleton, were all taken in two days, in the Buckenham marshes, between Norwich and Yarmouth, some thirty years ago, prior to the formation of the Great Eastern Railway, which now traverses those once noted snipe grounds.

The Winterton marshes, near Yarmouth, are incidentally mentioned by Messrs. Sheppard and Whitear as a nesting place of this species in 1817, where, I believe, they were still met with in summer, within the last fifteen or twenty years, and at Horsey within the last five or six. For although the drainage of the salt marshes in both those localities had long before banished 
the avocet, the ruffs were but little affected. In like manner, also, there seems no reason to suppose that these birds ever bred in the brackish marshes at Salthouse, although frequently observed there as birds of passage. At Hoveton Mr. Blofeld has not known them as residents for more than thirty years; but in May, 1862, a flock of ruffs and reeves visited his marshes, and gave him hopes of their remaining, but all took their departure again after a few days' rest.

Mr. Lubbock, from personal observation, refers specially to the vicinity of Heigham Sounds as their head quarters amongst the larger broads; and the late Mr. John Kerrison remembered them years back in some plenty in the Ranworth marshes. At the present time, however, Hickling alone, of all that still wild country, is visited annually by a few of these birds, but, should they become exterminated, the race of Norfolk, may we not almost say, of British ruffs, will have become extinct. Can nothing be done to secure, before it is too late, the same protection for our resident waders, as is about to be afforded to the sea fowl on our coasts and the "loons" on our inland waters? In this instance, I know, the lord of the manor does his utmost to protect the ruffs and reeves in his marshes, but so long as no actual penalty attaches to the robbery of the nests, or the snaring of hen birds in the act of incubation, it is impossible to preserve effectually in such places. Idle hands will always be found ready to risk the trespass, so long as cash or beer at the village public forms a tempting bait, with but little fear of detection. In my own notes for the last sixteen years I find frequent entries with reference to both eggs and birds brought up to Norwich for sale from the Hickling marshes; and in the summer of 1866, when there were an unusual number of nests, a corresponding supply of reeves' eggs found their way into the hands of our bird-stuffers. 
Two, evidently fresh laid, were shown me on the 16 th of May, and four others, but slightly sat upon, on the 6 th of June. I have also notes of some taken in other seasons during the latter month.* As long since as 1824, Messrs. Sheppard and Whitear attributed the growing scarcity of this species in the Norfolk marshes to birds and eggs being alike eagerly sought after for the London market, and both, of course, for edible purposes. A curious instance of the attachment of the female for her eggs is also given by the same authors, who state that a reeve was caught on her nest by the warrener's boy at Winterton, in 1817, and carried by lim to his master, who ordered her to be set at liberty; the next day she was found on her nest again.

As to the date of the appearance of these birds, in spring, Mr. Fisher, in recording "the times of arrival of some of the summer birds of passage at Yarmouth in 1843" ("Zoologist," p. 248), gives the 25th of March as the first appearance of reeves, but adds, "I saw no ruffs for some days afterwards; may they not arrive separately, the reeves first?" + This is most probably the case,

* According to Montagu the "reeves begin laying their eggs the first or second week in May," and he had found their nests with young "as early as the 3rd of June." * * * When the reeves begin to lay, both those and the ruffs are least shy and so easily caught that a fowler assured him "he could with certainty take every bird on the fen in the season." And no doubt this system of making "two seasons," as adopted by some fen-men, thus verifying, as our author says, "the fable of the goose and the golden eggs," was the main cause of their diminished numbers; whilst after all, the birds taken in spring "frequently pine and will not readily fatten."

† In the "Zoologist" for 1868 (p. 1284), Mr. Cordeaux states that on the 20th May he saw "eight birds, like large sandpipers, feeding in a fifty acre grass field, adjoining the Humber." Of these, by a very long cross shot, he killed three, which all proved to be reeves in good condition and plumage, and the remainder he believes to 
since the ruffs, unlike any other birds of this family, being polygamous, no doubt keep apart from the reeves during the winter months; but I remember a ruff, still in plain garb, and two reeves being shot on the same day at Hickling, on the 26th of March, 1852. On the 15th of April, 1864, a fine ruff was shot on a ploughed field at Rumhall, near Hingham, almost in the centre of the county, and three others observed with it were said to be very tame. On Breydon, Mr. Frere tells me, they are seldom seen in spring, but a couple were shot on the ooze in May, 1864, another pair during the same month about five years before; and three reeves were killed on the beach at Yarmouth, on the 19th of May, 1866. 'These late arrivals appearing: simultaneously with knots, godwits, and other migrants, are evidently foreigners passing on to more northern breeding grounds. In the autumn the Breydon gunners usually find them more plentiful, and one of them asserts that he has killed four and five reeves in a day, but no doubt some of these would be ruffs without frills as well as young birds of the year. Again at Blakeney and Salthouse Mr. Dowell says they are most frequently seen, though in small numbers, towards the end of summer and in autumn, but in the spring of 1816 he lilled two at Salthouse, and two more were shot there in July of the same year. Both in August and September I have not unfrequently seen young and old birds (the ruffs, of course, without frills) in our birdstuffers' shops, sent up from Yarmouth. A reeve killed by Mr. J. E. Harting on the bank of

Lave been reeves also, as they "appeared all of the same size." The stomachs of two, he says, "contained the remains of somo small bronzed-winged beetles and earwigs, also sereral small sharp stones. These stones, felspar and quartz, must have been taken into the gizzard at a great distance from this place, and probably in a granite district."

2 II 
the North river, near Yarmouth, on the 2nd of October, 1863 , is the latest as to date that I have known in autumn, and in no single instance am I aware of this species having been observed during the winter months.* Mr. Harting's specimen, which is particularly referred to in his "Birds of Middlesex," was feeding alone at the time, and allowed of so near an approach before it rose that he could observe its actions minutely. In walking, he tells me, it picked its way daintily along the "rand," the body carried horizontally, and with trailed wings, the head nodding at every step. When flusbed it uttered no cry, but flew lazily away, and pitched again within forty yards, when he followed it up and secured it. It was in fine plumage and very fut, the stomach filled with the remains of small beetles mixed with minute particles of grit.

With the exception of Colonel Montagu's account of this species, so extensively quoted by Yarrell, Mr. Lubbock's observations on the habits of the ruff and reeve are both the fullest and the most trustworthy with which I am acquainted, and these having a peculiar local interest, whilst the "Fauna of Norfoll"" is out of print, I feel no hesitation in giving copious extracts therefrom.

The marked decrease in their numbers of late years he attributes to "the beauty of the bird having" caused it to be more than ever sought after. A ruff 'with his show on,' which is the provincial phrase by which the fen-men here designate one of these birds in the breeding plumage, is exactly the creature which all bird-preservers eagerly snap up;"

* In Ireland where, according to Thompson ("Birds of Ireland," vol. ii., p. 230), this species is not unfrequent in autumn but rare in spring, and is not known to have been a resident at any time, several specimens have been killed in October, and even as late as the 29th of November. 
being purchased not merely by the naturalist, but by any one desiring "a pretty object in a glass case." Of the assumption of its peculiar dress by the male he says, "The whole of this extra plumage is put forth in about five weeks. A ruff shot in the beginning of April, the period of their arrival, if the spring is fine, has a few caruncles about the base of the bill, and the feathers of the neck appear in a ragged and unsettled state; here and there a longer.one, half perfected, protruding. In a month this bird's 'show' would be complete.* The young ruffs of one year do not produce so perfect a "show' as older birds."

When in perfect plumage "the colours of the ruft's are so various that it is hard to say which is most common; perhaps the most general livery is reddish chesnut, or black and white bars; the rarest tint is certainly pure white. A hill of ruffs looked at from a distance on a sunny day, with the light glancing on their party-coloured plumage, was a very pleasing spectacle, though now of rare occurrence in Norfoll. To view them thus, it was necessary to be paddled by a skilful hand in a small punt up some main dyke in the fen, so as to approach completely screened from view by the high banks; for no bird is more vigilant, or more impatient of near approach, than this. It is therefore very difficult to shoot, although it may sometimes be allured within fair reach of the gun by means of a stalet or stuffed reeve. This, however, is only for

* The feathers which form the ruff, according to MIontagu, "are scarcely completed in the month of May, and begin to fall the latter end of June;" and the fowlers believe that the males "are not more than one season in arriving at maturity."

† 'This word, known to every Shakespearian reader, seems in process of time to have become corrupted as to its meaning. It appears to have originally signified a dead bird, set up so as to look like a living one. The method of making a "stale" is thus 
a very short period, when the ruffs, having broken up their ' hill,' disperse themselves about the marsh in search of the reeves. At this time the distance is extraordinary from which a ruff will come to a reeve whilst flying in circles round her nest. I have known a reeve thus put in motion bring three or four ruffs from the other side of Heigham Sounds, a very large sheet of water. This time of activity, however, is soon over; the nuptial plumage then falls off; the bird gives up the character of Lothario, and seems chiefly to study how he may most conveniently get fat before his autumnal migration. Indeed, the collar of long feathers worn by the ruff in spring, though beautiful, appears to cause the bird much inconvenience. The flight of a ruff in full plumage is like that of the fresh-arrived and tired woodcock, roused early in the morning after a flight which completed his last stage from Scandinavia; it is laboured, slow, and straight. No sooner does the bird get rid of these appendages than he dashes forward with all the buoyancy and swiftness of the rest of the genus. There cannot be a greater contrast than the swift-glancing, powerful flight of the reeve, and the laboured fettered motions of her partner during the breeding season." Colonel Montagu was evidently much struck with the power exhibited by practised fowlers of distinguishing a ruff amongst the herbage at an almost incredible distance, but on this point Mr. Lubbock remarks, "even a novice is surprised at the distance at which these birds, upright and motionless, are visible to the eye."

The "hill" as it is termed is simply a raised situation (on the bank of a marsh dyke for instance) upon

described in "The Experienced Fowler" (London, 1704, 18 mo., p. 18):- "You may shoot a lark or some other bird, take out the entrails, stuff him with tow, and dry him in an oven, his wings set in a flying posture; and so you may bo furnished at all times." 
which, at the nuptial period, the ruffs assemble, and each bird taking up his own position, resents the least intrusion on his domain, whilst the favors of the reeves form a further source of contention. Such a congregation is termed a "play of ruffs." The same hill is not always used, but the birds will "sometimes hill in one marsh, and the next season resort to a different situation entirely." Mr. Lubbock, evidently does not consider their combats as in any degree formidable, but rather to "threaten great things (as may be seen amongst dunghill chickens when they ruffle their feathers at each other without striking) than to perform much." On one occasion, and one only, he "counted eighteen ruffs upon one 'hill' in the Potter Heigham Marshes;" and when thus collected the birds keep continually "rumning to and fro, fighting and fluttering their wings until they quite flatten down the grass." If crowded at all on a hill there was contention, "but if there was plenty of room for each to walk about, they seemed to agree tolerably. The arrival of a fresh ruff upon a hill where some were already assembled, always caused unusual confusion for a minute or two,"* but he "never heard of a ruff being taken in a marsh through injuries received in battle."

Of the method adopted for capturing them in the marshes, and the numbers so taken, Mr. Lubbock says "nets were never used to take these birds in Norfolk," but snares made of horsehair, by which means a local fowler assured him "he once, and once only, took

* In confinement Pennant found the same contention amongst the males, each bird taking up its own stand in the room as it would in the fen, and the least encroachment on their respective circles invariably caused a fight. "They make use of the same action in fighting as a cock, place their bills to the ground and spread their ruffs." The same thing may be witnessed almost any year in one of the enclosures in the Zoological Gardens. 
six couples in a morning." * In the western Fens, however, Mr. Newton ascertained that they were both netted and snared. The formation and disposition of the snares is thus described by Mr. Lubbock:-_"Having found the hill, the Norfolk fowler prepares about a dozen pegs, sharpened at one end and split at the other: into the split he introduces the middle of a loosely-twisted link of long horse-hair, so as to form two nooses, one with each half of the link. The peg is then driven into the ground so as to be perfectly level with the surface, and one noose is placed horizontally, just raised by the herbage perhaps half an inch from the soil, whilst the other is disposed perpendicularly, the lower part resting on the ground. These snares are disposed on the outskirts of the hill rather than the middle, as the ruffs in their flutterings generally spring from the centre towards the circumference of this chosen spot. When a ruff is snared he, after an effort or two at escape, gives up the attempt and crouches quite close to the ground; the other birds also generally forsuke the hill until he is removed (but this does not invariably take place). A vigilant look out must be kept upon the place where the snares are set, if the fowler wishes to reap the fruit of his labour. The stoat and the brown rat, both of which are abundant in the marshes, are very quick in discovering the captured birds and devouring them: should they feed upon one, it is useless to attempt snaring any more upon that hill, until a trap has given the intruder a coup de grâce."

At the close of the breeding season young and old used to collect together "in large bodies," as evidenced

* This is nothing compared to the numbers formerly netted in Lincolnshire. Pennant speaks of forty-four birds taken at one haul, and six dozen in one morning; and states that one fowler would take from forty to fifty dozen in one season. 
by the fact that Mr. Lubbock once saw seventy or eighty together in a marsh near Burgh Castle, at the top of Breydon. These flocks, however, do not appear to have frequented the ooze like the godwits and curlews, but "the whole of their time was spent in the marshes," where they preferred a "wet swampy part of the fen," though in the breeding" season they chose the drier parts.

Both Pennant and Montagu have described at some length the method of fatting these birds for table, and the prices given even in former days show the high appreciation in which they were held as a delicacy ; it is strange, however, that we find no mention of them either in the Northumberland "Household Book" or in the "Accounts" of the L'Estranges, of Hunstanton.

In Pennant's time fat ruffs would sell for two shilling's or two shillings and sixpence a piece; and Montagu found that although a Lincolnshire fen-man received only ten shillings a dozen, the "feeder" asked as much as two guineas, * and never less than thirty shillings. In Norfolk Mr. Lubbock gives the price of freshly caught birds, at the time of his publication (1845) as six shillings a couple, but says that twenty years before they fetched only tenpence or a shilling a piece.

Several couples are not unfrequently to be seen in the Norwich Market early in May, which have been sent down from London for sale, but these, as far as I have been able to ascertain, are all procured in Holland.

* "At the present day," writes Folkard (1864) "the price paid for fattened ruffs is often as much as four guineas per dozen," but the system of feeding either ruffs or godwits for the London market has almost, if not entirely ceased. In Leadenball Market black-tailed godwits may now be purchased at eighteen-pence each and ruffs at a shilling, all imported from Holland. 


\section{SCOLOPAX RUSTICOLA, Linnæus.}

\section{WOODCOCK.}

Mr. Selby's often quoted remarks on the migratory habits of the Woodcock, as observed more particularly on the Northumberland coast, agree so nearly with the experience of our local naturalists, that it is difficult to describe the habits of this bird in Norfolk without apparent plagiarism. As the chief prize of the sportsman also, and the bonne bouche of the epicure, this popular migrant attracts universal attention, indeed its autumnal and vernal movements, though from widely different motives, are not less noted than those of the cuckoo, the nightingale, and the swallow.

The southward migration commences by the end of September* or beginning of October, when the first flights reach our shores from their northern breeding grounds. These almost invariably pass on to the southward or westward after a brief rest, and are followed by larger bodies at intervals, depending much upon the wind, throughout October and November, the later birds becoming more resident in our coverts; and even in December and January fresh flights make their appearance from time to time, but these, as is the case also with the snipe, almost invariably precede or arrive simultaneously with severe and stormy weather. On the 4 th of January, 1854, as Mr. Dowell informs me, a flight was seen at Blakeney during a gale from the north-east with severe frost and snow, and the same thing was observed at Yarmouth in January, 1867, during the intense cold

* I find but one or two records either in Mr. Dowell's or my own notes of woodcocks killed in September, and those very lato in the month. Thompson ("Birds of Ireland," vol. ii., p. 235), gives a few rare instances of their appearance in the north of Ireland towards tho end of September, and one as early as tho 8th. 
which prevailed at that time. Unusual numbers also occur at times from the same cause in the months of October and November. Their nocturnal migrations are certainly influenced rather by the wind than the moon, this species having been found abundant on our coast, after a dark night, with the wind from the north or north-east, ${ }^{*}$ which agrees exactly with Mr. Selby's experience that "they always come over in the greatest

* I am well aware, although quite unable to reconcile it with my own experience, that some naturalists maintain that our migrants arrive, not with, but against the wind; in other words that they prefer facing a strong head wind, and would thus fetch our coast, from the north of Europe, with the wind from the south or southwest. But although I can imagine a side wind to be more favourable than a "stern chaser," I cannot understand a long. continued flight in the very teeth of the wind being maintained without great exhaustion and consequent delay on the journey. In support, however, of this vierv of migration, Mr. Hele, of Alde. burgh, Suffolk, a very observing naturalist, makes the following statement in the "Field" of November 17th, 1866. "Last Tuesday whilst fishing along shore, I had a most capital view of a woodcock 'arriring.' 'The wind was blowing somewhat freshly from the north-west, so that the bird was flying directly to windward. Its speed was most remarkable. I do not remember having seen it exceeded by any other bird, if equalled [it has been estimated at one hundred and fifty miles an hour.] The elevation of flight was about fifteen feet. Two other woodcocks had been seen to 'make land' a fer hours previously." In reply, also, to the comments of a correspondent in the same journal, he writes ("Field," December 1st, 1866), "I have been able from actual observation to satisfy myself that many other species come to us from eastward during the prevalence of west and north-west winds-namely, starlings, larks in large flocks, with many smaller birds, which I have not been fortunate enough to identify; royston crows, rooks, and fieldfares ; and of those leaving, the swallows, sand and housemartins, also swifts, invariably pass towards the south-west at the time of the wind blowing from that point." This is strong evidence certainly on the one side, but not more so than can be readily adduced on the other. 
bodies in hazy weather with little wind, and that from the north-east." Their condition on arrival, some being extremely fat and others very lean, has, I imagine, but little to do with the wind being favourable or not for their passage, but depends rather upon the effects of "short commons," physical weakness at the close of the breeding season, or even stress of weather in the country whence they started. From whatever point, also, of the Scandinavian coast they wing their flight,* the passage is, in all probability, performed between sunset and sunrise, and if the tiny golderest survives the same perilous expedition the woodcock, though tired by its sustained efforts, need lose little in condition during its eight or ten hours journey.t Too

* In Norfolk, at least, the migration of woodcocks is not, as Bishop Stanley remarks in his "Familiar History of Birds," "attended with more mystery than that of most birds," for taking their starting point to be from the shores of Norway and Sweden, it is most natural that they should alight, as we know they do, on our eastern coast. A much more difficult problem, however, to solvo satisfactorily is the statement, on good authority, that in Ireland ("Birds of Ireland," vol. ii., p. 238) the earliest flights are seen on the western coast, and the same in the south-west of Euglandin Devon and Cornwall, and in the Scilly Islands. On this point Bishop Stanley's theory is, I think, the most plausible I have yet met with, that a flight of these birds having quitted the coast of Norway about dusk, might in their rapid flight, when high up in the air, pass unconsciously in the dark hours over the intervening land, and thus at day-break find themselves "far away to the westward of Ireland, hovering over the Atlantic." In turning once more to regain the nearest shore, they would consequently alight on the west coast of Ireland, the Scilly Islands, or the south-western coast of England.

+ Selby, in support of his assertion that these birds migrate at a considerable altitude, to avoid, as he presumes, the lower currents of air, states that he was informed by a respectable wild fowl shooter on the coast, that he had more than once seen the arrival of woodcocks from the north-cast at day dawn. His notice was 
tired, however, to pass on at once to more secure shelterparticularly those whose powers, as above stated, have been previously enfeebled-many fill victims to the keen sportsman, who, from experience knowing when and where to look for them, turns out early in the morning to search the marram-banks and fences bordering on the coast. The Denes and even, as Mr. Lubbock says, "the kitchen gardens on the outskirts of Yarmouth are some times, for a few hours, full of these birds; ten couple have been killed there by one sportsman." The rough marine herbage* also on the Blakeney "meals" forms a like resting place for a time, as well as for the large flights of blackbirds, that make their appearance on our coast in October so regularly that the gunners in those parts are accustomed to search for woodcocks when the blackbirds are over. $\dagger$

attracted by a sound high up in the air, which "he found proceeded from birds descending in a direction almost perpendieular; and which, upon approaching the shore, separated and flew towards the interior." Some alighted in the hedges close by, which he pursued and shot, and these proved to be woodcocks.

* Amongst the plants which here form a shelter for our feathered migrants, and a grateful relief to the eye after that wide waste of ooze and shingle, are the remote flowered sea lavender (Statice bahusiensis), sea lavender (Statice limonium), seaside starwort (Aster tripolium), annual seablite (Suœda maritima), shrubby seablito (Suoda fruticosa), seacoast wormwood ( $A$ bsinthium mavitima), and stalked sea-purslane (Otione portulacoides). Spurn Point on the Yorkshire coast, as we learn from Mr. Cordeaux ("Zoologist," 1868, p. 1318), is a similar resting place for the woodcock and goldcrest in the autnmn, offering like shelter in the marram grass, sea bind-weed, sea-holly, and thickets of prickly sallow-thorn.

+ The following extract from the "Household Book" of the L'Estranges, of Hunstanton, seems in a remarkable manner to confirm the joint arrival of these two species, thus recorded as far back as 1522. "Itm. pd to Stephyn Percy for ij woodcocks and iiij blackbyrds, iijd." This is the only instance in which the

$2 \times 2$ 
On the 8th of October, 1856, Mr. Dowell and a friend shot twelve woodcocks on the Blakeney sand-meals, beginning only at two o'clock in the afternoon, and therefore looking over only part of the ground; the previous night had been thick and rainy, with the wind north by east. He has also known Overton, the gunner, kill three and four couples a day, at such times, on the beach and sand-hills, having fallen in with a fresh flight, but, as a rule, on the next morning not a bird is to be found.

Like most nocturnal migrants the woodeock is attracted in its flight by any glare of light, and thus examples are not unfrequently picked up dead during the autumn months at the foot of our lighthouses, killed by their contact with the windows above, of which instances have come to my knowledge at Cromer, ${ }^{*} \mathrm{Hun}$ -

blackbird is mentioned in these acconnts, and being entered in the thirty-ninth week after the eighth of February, the date would fall about the first week in November. Pennant, also, gives some interesting particulars of the arrival and departure of woodcocks on the Suffolk coast from the observations of Sir John Cullum, Bart., most of which are equally applicable to this county. Amongst others it is stated that examples have been taken up exhausted in the streets at Southwold; and that "when the redwing appears on the coast in autumn, it is certain the woodcocks are at hand; when the Royston crow, they are come." In like manner the redwings are the harbingers of their return in spring.

* The Rev. W. B. Daniel in his "Rural Sports" (vol. iii., p. 159) makes special reference to the fact of woodcocks being thus attracted, and says that many instances have occurred at the Cromer and Eddystone lighthouses. He also states that in 1796, at the lighthouse on the hill of Howth, a pane of plate glass more than three-eighths of an inch thick was suddenly smashed by a woodcock flying against it with such violence as to break its bill, head, breastbone, and both wings. Bishop Stanley says also that, "no less than five woodcocks have killed themselves in a similar manner against the plate glasses of the South-Stack light-house, in Anglesey." See also Mr. Cordeaux's account ("Zoologist," 1867 , 
stanton, and Hasborough. A fine woodcock in my own collection met its death in a somewhat similar manner close to this city. It was found on the 23rd of October, 1858, against the wall of Mr. Towler's residence, adjoining Park Lane; and in this instance, no doubt, the lamps on Unthank's Road, which passes in front of the house, had so dazzled it that the next instant it dashed with full force against the front of the building. On examining it soon after it was picked up, I found the frontal bone completely smashed in. Others are also, occasionally, found dead under the telegraph wires, ${ }^{*}$ having flown against them in their migratory course, and some, I imagine, meet with a like fate in their ordinary nocturnal flittings. On one or two occasions I have had freshly killed woodcocks offered me for sale by the porters at the stations between Norwich and Yarmouth, or by men at work on the line, which, in such a locality, are very likely to liave been thus suddenly arrested in their flight from the woods on the one side to their marshy feeding-grounds on the other side of the railroad. $\dagger$ In "The Naturalist" for 1853

p. 1011) of woodcocks, wild ducks, snipes, gold-crested wrens, \&c., being picked up dead on the balcony of the Flamborough lighthouse. The light keeper informed him that "the woodcocks usually arrived with a north or north-east wind. Had once seen some arrive during the day."

* A still more remarkable occurrence was recorded in the "Zoologist" for 1866 (p. 271), by Mr. A. P. Smith, of Ipswichnamely, the death of a woodcock, from being impaled on the arrow end of a weathercock on one of the churches of that town, when passing over, it was presumed with others, on a dark night.

† A correspondent in the "Field" of March 21st, 1868, gives a remarkable instance of the serious injury which a bird of this kind may sustain through contact with the wires, and yet survive the blow. In this case "an extreme lacerated wound extended from the junction of the neck with the body in an oblique direction across the breast from the left to the right side, separating all the pectoral muscles from their insertions into the keel of the sternum, 
(p. 19), Mr. Thomas Southwell recorded the capture of a woodcock alive, on the 9th of October, at Lynn, under the following curious circumstances:-The door of an iron warehouse in that town having been left open until half-past six on the previous evening, a porter on entering in the morning found a strange bird, that proved to be of this species, perched on one of the stoves, and which allowed itself to be taken by hand though in good health and condition. In like manner, as Mr. Dowell informs me, a woodeock in broad daylight, on the 13th of October, 1849, flew into a fisherman's cottage at Blakeney, and settled in the chimney corner; and on the 7 th of November, 1867, one was caught alive in Broad Street, Lynn, about ten o'clock in the morning.

With the exception only of that portion of our coast line, bordering upon the "Broad" district, our extensive seaboard presents an almost continuous range of woods and plantations in close vicinity to the shore,*

cutting through the upper portion of the sternum, and exposing the pericardium and pleura." The bird appeared to be in a fair way of recovery. Mr. Alfred Newton tells me that by the side of the road, along which telegraph wires run, between Halifax and Windsor, in Nova Scotia, he found an example of the American woodcock (S'colopax americana), which had both wings and legs broken, and though it was in the afternoon and the bird had probably received its injuries in the night, it was still alive.

* Commencing with the shores of the Wash, and within a short flight from the coast, are the Sandringham coverts, the "Kenhill " wood at Snettisham (always famous for cocks), the park and woods at Huustanton and Holkham; and still further inland the farfamed coverts of Melton Constable and Swanton Novers; whilst from Salthouse to Hasborough, with but little interval, the woods at Letheringsett, Hempstead, Sherringham, Beeston, Cromer Hall, Fellirigg, and Northrepps, on the coast, with Barningham, Blickling, and Gunton, within a few miles, have all more or less attractions for woodcocks, and in most of them large numbers have been killed. 
thus affording immediate shelter to these autumnal migrants; while at the same time a fair sprinkling of cocks may be found, in most seasons, frequenting the moist carrs and thickets of alder, willow, and birch, that fringe the margins of the broads themselves.* But although, as might be expected, the coverts near the coast-especially those of Lord Hastings's, at Melton Constable and Swanton Novers, afford the largest bags, these birds are very generally distributed over the county; and around Norwich are found in various localities in close vicinity to the city.

What proportion the numbers that now visit this county in favourable seasons may bear to the migrations of former times, I have no means of ascertaining with any degree of accuracy, although an examination of the game books, so carefully preserved for years on our larger estates, would, I believe, throw much light upon this as well as many other subjects of deep interest to the sportsman and naturalist. In proof of this, I may subjoin the following abstract sent me by $\mathrm{Mr}$. Alfred Newton from the game books kept at Elveden, on the borders of this county. Mean number of woodcocks killed in the five seasons ending

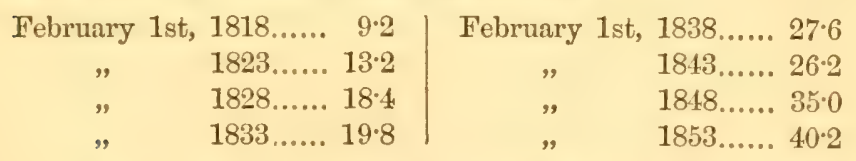

Or if we take decennial intervals, we shall find the mean for the ten seasons ending

1823 to be $11 \cdot 2$

$1833, \quad 18 \cdot 1$

1843 to be 26.9

$1853,37 \cdot 1$

* A year or two back a woodcock was killed on Surlingham Broad, during the day time, from amongst the small bushes on the open marsh. This was considered as an almost unprecedented circumstance in that neighbourhood. 
The seasons of 1815-16, 1816-17, 1828-29, 1829-30, and 1838-39, seem to have been of unusual scarcity; while those of 1817-18, 1825-26, 1834-35, 1843-44, and 1849-50 have been of abundance to a greater or less degree.

In the days when "glade nets" stretched across the openings, or "cock roads" in the woods were extensively used for taking them during their evening flight, and springes and snares were alike fatal in their marshy feeding grounds, there is no question that this species was extremely abundant; and of this we have also additional evidence from the small sums which they formerly fetched in the market* allowing even for the difference in the present value of money, whilst their excellence as a table delicacy $\dagger$ was as fully appreciated then as now. The causes of their diminution, however, must be looked for rather in other countries than our own, and whilst two such authorities as Mr. Lloyd

* In the Duke of Buckingham's "Household Book," 1507, eight woodcocks cost eightpence, and sixteen ditto sixteen-pence. In the "Household Accounts" of the Lord North (time of Henry the VIII.), it is ordered "that woodcokes be hade for my Lordes own Mees and non other, and to be at $\mathrm{j}^{\mathrm{d}}$. a pece or $\mathrm{j}$. ob. ( $1 \frac{1}{2} d$.) at the moste," the same price as lapwings and sea gulls, whilst pheasants, bitterns, and curlews were then a shilling each, spoonbills sixpence, quails and partridges twopence, and snipes three for a penny. In the L'Estrange "Accounts," also, we find an entry in the year 1520, of three woodcocks purchased in Snettisham market for sixpence; and in 1522 of six purchased from John Long, of Ingoldisthorpe, for tenpence.

† In Willughby's “Ornithology," published by Ray (1628), occurs the following passage with respect to the woodcock :- "The flesh of this bird for the delicacy of its taste is in high esteem;" and with special reference to the excellence of the leg, the author quotes tho old "English Rhythm"-

"If the partridge had the woodcock's thigh, T'would be the best bird that ever did fly." 
and Mr. Knox* deprecate altogether the assertion of some authors that this is mainly caused by their eggs being extensively taken in Sweden for edible purposes, (like those of the lapwing in England), the scarcity being attributed by Mr. Knox to an undue slaughter, not in the north but in the south of Europe. In support of this view he instances the enormous bags made, chiefly by British sportsmen, on the shores of the Mediterranean and of the Adriatic, giving as the grand total of six days' shooting in the winter of 1844-5-at Butrinto and on the Acheron and Achelous rivers-the prodigious quantity of one thousand and twenty-six woodcocks killed. On the other hand, we must remember that shooting birds in winter does not appreciably affect the stock that is left. All that such shooting does is to consume the annual increase of the species for the year. Some more valid cause must, therefore, be assigned for the decrease of woodcocks in England, if decrease there really be. That cause is not far to seek. In Sweden and Norway a practice much more destructive than egging obtains-that of shooting the birds immediately on their arrival in those countries, and throughout the breeding season, from the end of April till the middle of June. At that time of the year it is, unfortunately, the habit of the woodcock, evening after evening, to fly backwards and forwards over the same spot, and this in the bright summer twilight of those northern countries. Particular places are thus haunted by many birds, which further, by a most peculiar note, uttered on the wing, attract attention to the spot. Consequently the so-called "sportsmen" of the district repair to such a place, and the flight of the birds being then very steady, though extremely swift, many fall victims to this atrocious

* Lloyd's "Northern Field Sports" and Knos's "Game Birds and Wild Fowl." 
practice. The wonder is that any escape, and it is only owing to the vast extent of the Scandinavian forests and their thin population that any do so. From the Swedish word (roa, to play, impf. roade), which expresses this habit, comes the term "roading," used by many Englishmen in Scandinavia, and thus, Wheelwright, in his "Ten years in Sweden" (p. 195), says, "I generally shoot them [woodcocks] here when they are roading, and in a good stand can often kill three or four in an evening. A friend in Gothenburg wrote me word that, in the spring of 1864, he killed forty woodcocks round that place when they first came over."

With us, no doubt, the changes which have taken place, during the last fifty or sixty years, in the cultivation of waste lands, many hundred acres of heath, wood, and fen having been alike subject to the plough, with the thinning of hedgerows and field timber generally, have materially lessened the attractions of the soil; and at the same time the strict preservation of game, with the requirements of the "battue," make it impossible to arrive at any satisfactory estimate of the numbers that now visit us in an average season.

On all those estates where a considerable head of game is reared for, probably at most, only three or four days' sport towards the close of the year, the woods are necessarily kept quiet until that period arrives; and thus, although many flights of woodcocks from the beginning of October may have rested there for awhile and passed on scathless to more southern quarters, it is quite possible that the very week of the "grand battue" may produce only a few stragglers that have located themselves for the winter. Of course the reverse of this picture occurs at times, when severe weather about Christmas has driven the cocks into close cover; still the great bags made during some seasons in Treland, as recorded by Thompson and other authors, 
are the result of repented visits to the most likely spots, between October and March. By the same means, at Hempstead, near Holt, a very favourite resort in this county, from one hundred to one hundred and fifty cocks have been lilled in one year, and yet comparatively few in other seasons, when the same coverts have been entered only for battue purposes. In such woods, also, the sportsman, who wallss with the beaters and takes his chance in the "lhigh fell" will bag more cocks to his own gun, if a good "snap" shot, than all the rest of the party, though posted in convenient drives or other openings.

With the woodcock also, as with the snipe, there seems to be a strange partiality for certain localities. There are few sportsmen who cannot re-call some favoured spot where, year after year, a woodcock was to be found in due season, and whose place, if killed, was almost sure to be taken by another. Mr. J. H. Gurney tells me that he remembers, many years ago, when the late Rev. Robert Hankinson occupied Bilney Hall, near Lynn, being told that there was a remarkable place of this kind on the grounds attached to that house. The attraction in such cases being, no doubt, some peculiar adaptability of the aspect, soil, and leafy shelter.*

Some years are certainly noticeable for the scarcity of woodcocks as others for their abundance; but of the latter, the most remarkable of late have been the autumns of 1852 and 1858, and the last three or four seasons have been all more or less favourable. In the memorable "flood year" (1852), amongst other

* Sir Humphrey Davy ("Salmonia," p. 332, 2nd edit.) remarks, "A laurel or a holly bush is a favourite place for their repose: the thick varnished leaves of these trees prevent the radiation of heat from the soil, and they are less affected by the refrigerating influence of a clear sky; so that they afford a warm seat for tho woodcock." 
ornithological phenomena, an almost unprecedented quantity of cocks were killed in the month of December. Mr. Alfred Newton, who took some pains at the time to ascertain the numbers shot in different localities, states ("Zoologist" 1853, p. 3754), that "in the first week in December thirty and thirty-three were respectively killed, on two successive days, at Melton Constable, near Holt; and on the next day the same shooting party bagged ninety-three in the Great Wood at Swanton Novers." He was also informed on good authority that "no such number as this last had been seen there for twenty years; and further, that at least one hundred and ten might have been killed if the other game had been disregarded." These coverts are always reckoned as the best in Norfolk for woodcocks, but at other likely spots near the coast considerable bags were made. At Felbrigrg, says Mr. Newton, "6twentyseven, thirty, fifteen, and twenty-one respectively were killed on four days in the second and third weeks of December;" and at Holkham "twenty-nine in one day about the same time." Mr. Newton, however, gives reasons for believing that in this instance the increase was rather local than general, possibly induced by the flooded state at the time of a considerable portion of the county, and that such was the case seems the more likely from the fact that the amount killed in some parts of Suffolk, usually considered extremely favourable for this species, was far below the average. Considering, also, as before stated, that many annually resort to the low carrs and plantations in the neighbourhood of the broads, it is quite possible that these, when driven from that district by the rising of the waters, collected in large bodies on the higher grounds, whilst fresh arrivals on the coast had no inducement to disperse themselves further over the county. 
In 1858 the numbers that visited us were easily accounted for by the severe and lasting frosts which immediately succeeded their arrival. Snipes were plentiful at the same time, and the quantities of siskins, redpoles, and twites indicated a more than usual amount of cold in more northerm comntries. At this time, in the same wood at Swanton, where so many were shot in 1852, eighty-three woodcocks were killed in one day in the second week of November. In the autumn and winter of $186 \mathrm{t}$, the weather being somewhat severe, a very large number appeared on our coast, and at least one hundred couples, as I was informed at the time, were then killed in the coverts at Melton and Swanton. Mr. T. E. Gunn also states in the "Zoologist" for 1865 (p. 9468), that during the previous autumn scarcely a week passed that he did not see a dozen woodcocks hanging for sale in the Norwich Market, and that he heard of sixty-one having been killed about the last week in November, in a single wood at Gressenhall. Again in the years 1865, 1866, and 1867, very considerable flights reached us late in the autumn. In the former year, though rather a mild season, about one hundred and fifty-five were said to have been killed at Swanton and Melton in four days' shooting; sixty-seven in one day, and fifty-seven from Swanton wood alone.* In 1867, in the same woods, fifty-one were shot in one week in November, just prior to the commencement of very severe frosts.

The return of the woodcocks in the spring of the year, which usually occurs in March, is, comparatively speaking, but little noticed. $\dagger$ The shooting season being

* See "Field," January 6th, 1866.

+ "The nearest approach I ever saw," writes Mr. Lubbock, "to the migration of this bird from England, was on the 10th of March, 1824: a pair of woodcocks passed across the road near Caistor, within a few yards of me, flying one behind another directly for the beach, which was within a quarter of a mile." 
then over, with the exception of a few couples chiefly shot by the gamekeepers, their brief rest in our coverts is but little disturbed. Considering, however, that at this time they are no longer a delicacy for the table, their flesh being dry and flavourless, and that every year proves them more and more inclined to remain with us to breed, it is greatly to be regretted that both woodcock and snipe should not be included in the list of game, protected from further persecution after the 2 nd of February. For several years past I have invariably seen one or more woodcocks hanging for sale in the Norwich fishmarket during the first and second week in April, birds which, there is no doubt, would have bred in this county, if indeed they had not already either egg's or young. Mr. Anthony Hamond, jun., the master of the West Norfolk Foxhounds, also assures me that during his last week's hunting, at the end of March, 1869, he saw some twenty or thirty woodcocks in different coverts nearly always in pairs, whilst at that time of year he has seen them sitting on their eggs in the North-west of Scotland.*

Here, too, may be remarked that amongst the many strange incidents connected with the history of this species, is the fact that although as migrants their numbers have greatly diminished, yet the tendency to remain and breed in this country seems as much on the increase. That this is attributable in a great degree to the extensive system of planting adopted of late years, both here and in Scotland, more particularly of larch, spruce, and other firs, seems generally admitted; $\dagger$ yet from a few records remaining of wood-

* Mr. St. John ("Wild Sports in the Highlands," p, 220), states that he had three eggs brought him on the 9th of March, 1846: and a nearly full grown young one in the second week of April, 181.

† Mr. Hewitson ("Eggs of British Birds," vol. ii., 3rd ed., 
cocks' nests discovered many years ago, it seems probable that if in those days as much attention had been devoted to the habits of birds, as at the present time, still more instances would have been forthcoming.

Mr. Lubbock speaks of a nest discovered in 1827, " in a wet low carr in the parish of Hickling. The old bird was killed by a stoat, on her nest, and the eggrs sucked," but, he adds, "her wings, however, which were shown by the person who discovered the nest, prevented the possibility of mistake as to the species." The same author also states (1845) "that three young" woodcocks were taken in Brooke wood a few years back." In 1848 MLr. Alfred Newton recorded in the "Zoologist" (p. 2148) the finding of a nest with four eggs, at Riddlesworth, near Harling, by a man cutting reeds, about the middle of April, and the eggs when blown appeared to have been set upon about a week. In the same year, also, according to Messrs. Gurney and Fisher ("Zoologist," p. 2185) another nest containing four young was found at Rainham, near Fakenham, on the 2nd of May; and Mr. Southwell informs me that he has eggs in his collection from the neighbourhood of Holt. A pair of old birds with nestlings, in Mr. Gurney's possession, were

p. 349), from his own observations on the breeding of tho woodcock in the forests of Norway, says, "in these it chooses those places for its nest from which the trees have been cut down, on the outskirts of the forest, and bordering upon the cultivated districts and the banks of the rivers. Whilst there we had the pleasure of taking its eggs, which were placed upon the bare ground, under some brushwood, and in a place from which the timber had been cleared, and in which the young spruce fir-trees were again springing." From this we may presume that our young fir-coverts are far more suited to their breeding habits than were the old oak-woods and hazel-copses of which so few now remain, having been stubbed up and cultivated or entirely replanted. These, howerer, from their denso undergrowth and leafy shelter, had peculiar attractions for them in autumn and winter. 
taken some years since at Stratton Strawless; ${ }^{*}$ and in Lord Hastings's collection is a case containing a pair of old birds and three young ones, which were hatched at Melton Constable, but the exact date is not known. Mr. Lambert, gamekeeper on the Kimberley estate, assures me that at least forty years ago he knew of a woodcock's nest in the woods at Blickling; another was seen about three years back at Hempstead, by Mr. Thomas Edwards; and some twenty years since, as I learn from Mr. Southwell, the shells of woodcocks' eggs, in a nest which the young had just left, were found at Bawsey, by Mr. Burlingham, of Lynn. At Fakenham Wood, in Suffolk, but not very far from the border, Mr. A. Newton has heard of woodcocks breeding more than once, though some twenty years ago. From Culford he has also a nest with a rotten egg, taken after the others had hatched, in 1867. The nest is a deep cup of dry oak and Spanish chestnut leaves.

Of more recent date the following are all that have come under my own notice, but I doubt not that further enquiries would elicit even more instances :-

On the 2nd of May, 1851, a pair of young birds about three weeks old were sent up to Norwich for preservation, taken at Holkham; and a third nestling was kept alive for several weeks, but from want of caution in feeding itself was choked, as supposed, by the "diet" of worms. About the same time a gamekeeper at Brooke, flushed an old woodcock and four young ones, and succeeded in catching two of the latter. On the 17th of May also of that year, I saw a fine old bird, quite fresh, hanging up for sale in our fishmarket.

* Morris in his "British Birds" (vol. iv., p. 254) states that a woodcock was shot at Mr. Marsham's, of Stratton Strawless, in Norfolk, about the 7th of June, 1847. The same fact is also recorded in the "Zoologist" for that year (p. 1876) by the Rer. H. T. Frere. 
In 1853, three eggs (which had been incubated about half their time) were found on the 14th of April, in the Mill Carr, near Buckenham House, then the property of the Hon. F. Baring (subsequently Lord Ashburton) and brought to Mr. Alfred Newton. These were small and rather singularly marlied examples, as may be seen by the representation of one of them in the last edition of Mr. Hewitson's work (pl. xevi., fig. 1.) On the 6th of May, of the same year, two young birds in the down, were taken from a nest at Cossey. These pretty little creatures were kept alive for some weeks in a patent hydro-incubator at that time exhibiting in Norwich, and appeared to thrive well in its artificial warmth, but were afterwards killed for stuffing, when sufficiently fledged. A few days later a nest of four eggrs, richly blotehed with brown, was found at Swafield. Three of these passed into the possession of Mr. J. H. Gurney, and one is now in my own collection. One or two nests were, I believe, also found about the same time at Holkham.

In 1854 several woodcocks were seen at Ranworth as late as the 26th of April, but no nest was found in that neighbourhood, and in 1859 a single bird was flushed on the 10 th of May, in a plantation at Spixworth, but was not observed there afterwards. On the 28th of April, however, of the latter year, a nest was found in a valley planted with birch and oak, near the Beeston hills, about two hundred yards from "Larry's cottage," a well known locality in the vicinity of Cromer.* The bird was flushed by a boy passing near, who at once detected the nest on the ground, covered with seared leaves and dried ferns. It contained four eggs, two of which were hatched on the 19th of May, the other two being left

* 'The same, I have no doubt, recorded in the "Zoologist" for 1859 (p. 6562.) 
with the broken pieces, and from that time neither parent nor young were again seen. In spite of the intrusions of various spectators, the poor bird sat very closely, and even allowed itself to be photographed on the nest by Mr. S. G. Buxton, without evincing any particular alarm. According to the statement of Dr. Fitch, who watched her through a glass, and to whom I am indebted for the above particulars, "she rested her bill apparently on the ground, with her large and prominent eye very wide open," and in this case a small rill and several little pits of water were situated within about one hundred and fifty yards of the spot selected.

In the second week of April, 1860, a nest with four eggrs was taken at Taverham, and on the 6th or May, 1861, two young birds, partially feathered, were sent up to Norwich to be stuffed, which had been captured on Mr. Bedingfeld's property at Ditchingham.

Again in April, 1862, I was informed that one or more pairs were supposed to be breeding at Taverham, which I have no doubt was correct, as an old bird was flushed there on the 1st of June, but the coverts being kept quiet on account of the game, no search was made for the nests. A pair were also seen at Kimberley, by Mr. Lambert, about the 6th of April of that year.

In 1864, Mr. Southwell received eggs of this species taken somewhere in the neighbourhood of Fakenham; and a single bird was flushed in Catton Park, near Norwich, as late as the second week in April.

On the 4th of May, 1867, I was told by Mr. F. Norgate, of Sparham, that he knew of a woodcock's nest, at Attlebridge, about eight miles from Norwich, on Mr. Micklethwait's property, where others have, I understand, been seen in previous years; and a correspondent in "Science Gossip" for 1866 (p. 88), signing' himself "E. A., Norwich," states that in the 
previous summer, at Attlebridge, Mr. Micklethwait's gamekeeper found five or six nests, and "this was not an exceptional case, as for several years past he had been aware that some were to be found, and even captured a young one."

On the 6th of May, 1867, a pair of woodcocks were seen in a low moist carr close to Hoveton Broad, but no nest was discovered; and on the 17 th of that month. a nestling was sent up to Norwich to be stuffed, which, with three others, had been hatched on Mr. H. N. Burroughes's estate at Burlingham.

Last of all, to my knowledge, up to the present time, a nest with two eggs was found in a plantation at Bixley, near Norwich, about the 24th of April, 1868, and in this case, also, the bird allowed itself to be photographed on its nest* by Mr. John Gurney, of Earlham, and eventually brought off her young ones.

From such repeated instances, then, of the breeding of the woodcock, there can be no question that were they protected in the early spring, the number that now remain with us throughout the summer would be greatly increased, and while the same birds would return again and again $\dagger$ to their accustomed haunts, as do other

* The extreme tameness of the brooding woodeock is mentioned by Pennant, who states that "a person who discovered one on its nest, has often stood over and even stroked it: notwithstanding which it hatched the young, and in due time disappeared with them." It seems, also, in former days to have ranked with the dotterel as a foolish bird, for in Willughby's "Ornithology" it is remarked, that "amongst us in England this bird is infamous for its simplicity or folly; so that a woodcock is proverbially used for a simple, foolish person."

* Of the attachment for, and return to, any particular spot evinced by the woodcock, two remarkable instances are given in Daniel's "Rural Sports." In 1798, a woodcock caught alive in a rabbit net was turned loose with a brass ring on its left leg. This occurred in February, and in the following December the 2 P 2 
migrants that annually visit us in the breeding season, a local race, as it were, would ere long be established.

From Mr. St. John's observations on the breeding of the woodcock in Scotland, this species appears to have more than one brood in the year, as he found their nests at any time between March and August, but from the entire absence of these birds from the woods early in the autumn, he was led to believe that all that are bred in that country emigrate with their parents about the beginning of September. Such also appears to be the case in Norfolk, as neither young nor old have been observed from the beginning of August to the close of the following month. I am not aware that the method adopted by the woodcock for carrying its young in the dusk of the evening from their nests in the roods to some moist feeding ground has ever been remarked. in this county, but this interesting fact has been fully established on the authority of many trustworthy observers. St. John ascertained that "the old bird lifts her young in her feet,* and carries them one by one;" and $M_{r}$. A. Hamond, jun., of Westacre, informs me that when in company with a friend and a gamekeeper, at Shielda, near Dingwall, in Ross-shire, he saw a woodcock in the act of carrying a young one in its claws for some distance. The old bird then returned, and clucked about like a hen to draw the rest of the brood

same bird was shot in the same wood where it was first captured. Again, in February, 1802, another woodcock, captured in the same locality, was turned off with a tin ring attached to its leg, and the same bird was killed in the same rood, on the 11th of December following.

* The editor of the "Ibis" (1868, p. 109) in reviewing a monograph of the woodcock, published in German, by Dr. Julius Hoffman, wherein this habit of transporting the young is referred to, remarks, " a friend of ours assures us it is effected by the parent grasping the young between the tarsi, and holding at the same time the bill downwards and backwards under the young bird." 
to her. His friend had observed the same proceeding on several occasions.

Space will not admit of my referring at any great length to that much vexed question, the possibility of accurately determining the sexes of woodcocks through size and plumage, but Mr. Gould, who has had unusual opportunities for investigating this point, and has dissected, measured, and weighed, several hundred specimens, asserts in his work on "The Birds of Great Britain," that at the end of a day's shooting, he is still unable to say with certainty, from external features only, which are males and which females. This he attributes to the fact of there being two distinct raceslarge and small (as occurs in many other birds) though not admitting of specific rank, and adds, "during their vernal migration these races generally keep separate from each other, and some flights will be composed of a small red race, while others will be exclusively large dark grey birds." As with the common snipe, "the male is undoubtedly the larger bird"; such he believes to be the case with the woodcock, "if there be any difference between the sexes," but on dissection he has proved " that many of the long-billed birds are females." As to the outer primary of the wing forming: a sexual distinction as supposed by some sportsmen,the males being said to have the external margin of that feather plain or devoid of tooth-like markings, whilst the same feather in females exhibits such markings, Mr. Gould thus disposes of that theory from his own experience. "They [the tooth-like markings] are absent in both sexes of very old birds; for I have wings of females in my collection in which the outer margin of the first primary is totally devoid of the toothed character. When the young woodcock assumes his first primaries, which he does at the age of two or three weeks, the outer feather is strongly marked; as he grows older 
this feature gradually disappears; and I have frequently seen specimens with the outer primary toothed for half its length, and the other part plain." Mr. Gould also gives a table showing the difference in the length of wing (measured from the carpal joint to the end of the first primary), as well as in the weight of twelve male and twelve female woodcocks, selected indiscriminately from the large and small races, and from which it appears that the wings of the twelve males " amount to eighty-nine inches, and their weight to one hundred and forty-two and three-quarter ounces; while the wings of the females are eighty-seven and a quarter inches, and their weight one hundred and thirty-five ounces; consequently the excess of the length of the wing in the twelve males is one and three-quarter inches, and of their weight seven and three-quarter ounces." He also believes "the males have generally the shorter bill, the longer wing, and the finer tail, while the rump of this sex is more red and the barrings of the under surface of the body more distinct. Much difference also occurs in the colouring of the legs of the woodcocks, some being olive or leaden white, while others are pale yellow." After weighing: a very large number of specimens of both the large and small races, he arrives at the conclusion that "the weight of seventy out of eighty birds in fair condition will range between eleven and fourteen ounces ;* of the other ten some will be lighter and others heavier. Light birds vary from nine to nine and a half and ten ounces." It is a very large bird that weighs fifteen ounces, and an extraordinary one that reaches sixteen

* Three remarkably fine woodcocks in the collection of Mr. Owles, of Yarmouth, netted a few years since in the month of January, at Mettingham, near Bungay, weighed together thirtynine ounces and two drams, the largest being just fourteen ounces. These were taken at night in a stubble field with a common lark net. 
ounces.* Monster woodcocks, however, of even greater weight than sixteen ounces have been recorded at various times, and amongst others Yarrell mentions a truly gigantic bird said to have been killed about the year 1775, in the long plantation at Narborough in this county. The particulars respecting it, supplied to him for publication by the then Lord Braybrooke, are contained in a letter from Lady Peyton to Miss Hoste in 1801. Having described its being shot during a deep snow, whilst perched on a very low branch of a spruce fir, weighed down to the ground, her ladyship remarks, "I saw it weighed both in scales and steelyards, as did Sir Henry and a carpenter at work from Swaff ham, and wonderful as the weight may appear it was exactly twenty-seven ounces. I believe it was about 1775 or 1776. Some years before that a woodcock was killed at Hadleigh, in Suffolk, which weighed twenty-four ounces." Lord Braybrooke also referring to another large bird observed in this county, says, "the Earl of Leicester told me that he, in company with Mr. Ralf Dutton, when they were young men, followed a gigantic looking woodcock for some hours, near Holkham, but could not get at him." In the two first instances the weight is so extraordinary that in spite of the apparent authentication, one cannot help suspecting some error or deception in both cases.

Pied and other varieties are occasionally, but not often, met with, and are, therefore, eagerly sought after when once seen. The most beautiful specimen I ever saw was killed at Hanworth, near Aylsham, on the 6th of November, 1856. Like one described

* Sir Thomas Browne (Wilkin's edition, vol. iv., p. 380) has the following memorandum in his "Common Place Book:" "A woodcock in the total, weighed twelve ounces, and the feathers weighed three-quarters of an ounce." 
by Mr. Edward Newman in the "Zoologist" for 1855, (p. 4631), all the markings peculiar to the woodcock in its usual plumage were in this bird more or less fiintly indicated by the most delicate buff or firwn tint on a ground of white, whilst those parts which in the normal colouring of the species are deepest, were liere also most plainly discernable. The whole of the under parts were white, yet still showing the usual bars when closely examined, resembling the faintest water markings, visible only in the strongest light. On the 16th of November, 1864, a curiously pied bird, now in the possession of Lord Hastings, was shot at Melton Constable. In this specimen all the primaries of one wing, except the fourth, and the wing-coverts, were pure white, and in the other wing the three first primaries and one or two feathers in the coverts; the rest of the plumage being of the usual tint. On the 17th of March, 1859, a woodcock was also killed near Lowestoft, in Suffolk, having the back and wings thickly sprinkled with white feathers, as were also the sides of the neck and the under parts generally.

Selby mentions the exquisite sense of touch possessed by this and allied species from the nervous apparatus distributed over the anterior portion of the beak, enabling them to detect their food unerringly when boring deep in the soil, and also the power of expanding the tips of the mandibles, in order to seize and draw out their prey, but as far as the upper mandible, at least, is concerned, this strange faculty appears to be developed in a remarkable manner in the woodcock. Mr. F. Norgate, of Sparham, on one occasion having slightly winged a woodcock took it home alive, and he assures me that the flexibility of the upper mandible was so great that it resembled more the writhings of a worm than a beak, and from the slight sketch, with which he furnished me at the time, 
its uprvard curling is suggestive of that most sensitive organ of touch, the proboscis of an Elephant.* Their food consists chiefly of worms, of which they consume immense quantities, and, as with the snipe, the "borings may be frequently detected in their moist feeding grounds. In the breeding season the woodcock utters a curious squeaking note when taking its evening flight, but in the autumn and winter it but rarely emits any cry when flushed by the sportsman, though the peculiar noise made by the bird (probably with its wings) in rising, when once heard is never to be forgotten. Mr. S. Bligh informs me that he once came upon a woodcock so suddenly at Framingham, near Norwich, that, on rising, it uttered a peculiarly shrill cry of alarm.

The following curious fact also with regard to this species which I have not elsewhere met with, is recorded by Mr. Gould, on the authority of Captain Murray Aynsley. That gentleman, when shooting in the coverts at Alnwick, in Northumberland, observed a woodcock pitch down within eight yards of him on the opposite side of a fence where the ground was bare, with the exception of a few leaves. These the bird, on alighting, threw over its back with its beak, squatting close to the ground all the time, and was more than half covered when the beaters came up; nor did it attempt to rise until flushed by a dog.

Of course no history of the woodeock in Norfolk would be deemed complete without some reference to the memorable exploit of Sir Francis Chantrey, in killing two birds at one shot, when shooting at Holkham; for, although this feat has been accomplished by other sportsmen, the artistic celebrity of the performer, and the monument erected by himself to the memory of his

* The voluntary upward movement of the upper mandible in the woodeock is described at some length, and illustrated by a wood engraving, in Dr. Hoffman's monograph above mentioned.

$2 \mathrm{Q}$ 
own prowess, have invested it for all time with a peculiar interest. In an amusing little work by Mr. J. P. Muirhead, entitled "Winged Words on Chantrey's Woodcocks,"-being a collection of the numerous poetical jeux d'esprit, with which the great sculptor was honoured by his friends at the time, the particulars of the occurrence are minutely detailed, and an extract from the Holkham game book fixes the date as November 20th, 1829.* It is also stated that the spot where the lucky shot was fired has been handed down to posterity by the name of "Chantrey Hill." The beautiful marble group $\dagger$ (figured in Yarrell's "British Birds") representing two dead woodcocks, which was subsequently executed by Chantrey, as a commemorative gift to the late Earl of Leicester, now adorns the library at Holkham, and the original cast or model is preserved in the Chantrey gallery at Oxford. From amongst the many quaint poetical effusions on this "double event" (amounting to no less than one hundred and seventynine), as collected and published by Mr. Muirhead, I have selected the following as especially worthy of record:-

"Life in death, a mystic lot,

Dealt thou to the winged band:

Death,-from thine unerring shot,

Life,-from thine undying hand."

THE Bishop OF OXFord.

"Driven from the north where winter starved them,

Chantrey first shot, and then he carved them."

The late Mr. Hudson Gurney.

* The shooting party that day consisted of Mr. Chantrey, Mr. Glover, Mr. Stanhope, Mr. Coke, and Mr. Digby.

+ Strangely enough the date of the event, of which this group was intended as a memento, is carved on the marble as 1830, but unquestionably, as shown by the game book, it occurred in the previous year.

\# This version of the couplet differs both from that published by Yarrell and the one given in "Winged Words," but is, I am informed by Mr. J. H. Gurney, the correct reading. 


\section{SCOLOPAX MAJOR, Gmelin.}

\section{GREAT SNIPE.}

The solitary or "double" snipe, as it is provincially termed, is a regular autumnal visitant, though for the most part in small numbers, and appears with the earliest flights of the common species in August and September. From my own notes for the last twenty years, I find the 17th of August and the 14th of October the earliest and latest dates of its occurrence in Norfolk; and in no instance have I heard of its being killed here during the winter months. Another peculiarity also of this bird is the fact that it is scarcely ever known to visit us in spring, when the common snipe again makes its appearance, in considerable numbers, on its northward passage. Writing of this species, Mr. Lubbock remarks "they are never to be found in March, the usual period of the snipe's vernal migration," nor do I now know of more than one or two authentic instances, and those, no doubt, stragglers driven accidentally to the westward of their usual migratory course.* An adult bird in the collection of $\mathrm{Mr}$. Alfred Master, of this city, was killed a few years back on Yarmouth beach in the spring, under the following curious circumstances. It was observed by a fisherman who was putting off to sea in his boat, flying low over the waves and making direct for the shore, where it alighted on the beach. Having a gun with him he went at once in pursuit of it, and from him it was purchased in the flesh by my informant Mr. S. Bligh. It must

* Mr. Selby describes the "direction of their latitudinal flight as much to the east of the longitude of the British Islands," but though in England they are apparently most frequent in the Eastern Counties, yet according to Thompson they also occur occasionally in Ireland.

2 \& 2 
be here noticed also that in the "Zoologist" for 1851 (p. 3175) Mr. P. E. Hansell, of Thorpe, near Norwich, recorded a supposed instance of the Great Snipe breeding in Norfolk, the particulars of which are thus given. "In the April of 1846, I found a nest of the great snipe containing four eggs, one of which is now in my collection; the others were broken by a boy who was with me, whilst stepping into my boat. The nest was placed in a tuft of grass, in some marshes at Belangh, near Wroxham, in this county. I had a good opportunity of observing both the birds, as they did not rise in the usual quick manner of the common snipe, but much more leisurely, and continued to hover round the nest for some little time." In support of his statement, Mr. Hansell also says that "a male specimen of this bird was shot near Lowestoft, in Suffolk, the latter end of April" in the same year. There is, however, a very large snipe occasionally met with in our marshes, which answers exactly to the description of $\mathrm{Mr}$. Gould's "russet" snipe, as given by that author in his "Birds of Great Britain," and to which I shall have occasion to refer more fully in my account of the common species. Having shot this bird myself on one occasion, and seen two others on the wing, I can speak to its great resemblance in size and action, when flushed, to the great snipe. It utters no cry on rising, and flies slowly and steadily, and would, I believe, by most sportsmen be taken for the great snipe until brought to bag, when the white of the under parts of the plumage at once determines the species, in spite of its bullk and extraordinary length of bill. May not the birds seen by Mr. Hansell have belonged to this large race of S. gallinago, whose eggs most probably would be proportionate in size? Any how, there seems to be no doubt that the egg taken as above described, and which has been presented by $\mathrm{Mr}$. Hansell to the 
Norwich Museum, is only an unusual variety of the common snipe's. Mr. Alfred Newton, to whom I recently forwarded it for comparison with his fine series of eggs, both of the great and common snipe, remarks, "I can nearly match it as to colour and entirely as to size by common snipes' egrgs in my collection, while it is considerably smaller than any great suipe's I have. I can scarcely doubt its being a common snipe's, the slight difference in colour from mine being owing, probably to exposure to light or air, or both." The great snipe also breeds much later than the common species; $*$ besides, as before stated, being extremely rare, as a spring migrant.

Mr. Lubbock, in his "Fauna," as well as in notes supplied to the late Mr. Yarrell, gives some interesting particulars of this bird from his own observations. In flight, he says, "it does not appear strikingly larger than the common snipe, which it does not much exceed in length from bill to tail, or extent of wing; its bulk is the effect of high condition. Of many fresh specimens which I have examined, all, without exception, were lumps of fat. One which I shot burst from the fall. In rising it may at once be distinguished from the common snipe by the tail, which spreads out like a fan, and shows a great deal of white. It lies until nearly trodden upon, and its flight is slow and heary. A drier marsh seems to content it than those which the snipe and jack snipe delight in. But this may arise in some degree from the early period at which they arrive." The term "solitary" he considers as misapplied to this species,

* Mr. Hoy, who found many of their nests in Holland, describes them as breeding early in May; and the Rev. H. B. Tristram found them breeding in great numbers in marshy swamps, near Bodö, in Nordland, in the early part of the summer. Sec Hewitson's "Eggs of British Birds," 3rd ed., vol ii. 
it being most frequently found in pairs, and instances the fact of a fen-man, at Sutton, having "killed six in the second week of September, 1835; four of these birds were in pairs, and proved male and female respectively." The heaviest bird he has known weighed ten ounces, but the usual weight is from seven and a half to eight and a half ounces. I have never had the good fortune to meet with the great snipe, although I have known it killed the next day on the very same marsh to which I had devoted the whole of the previous morning. Of some thirty specimens, however, that I have handled at different times, the finest, killed on the 8th of September, 1858, weighed nine and a half ounces.* Since I commenced making notes of such occurrences I cannot remember an autumn in which $I$ have not known one or more killed in Norfolk; and in some years they have been pretty numerous; but their usual scarcity, in these parts, brings them invariably under the birdstuffers' hands, and not, as in other countries, to table, as one of the finest of feathered dainties. Messrs. Sheppard and Whitear, who had also opportunities of examining several Norfolk killed specimens, remark that in this snipe the "legs are of a light flesh colour blended with a slight tinge of green. The length of the bill is subject to great variation."

In Mr. Hunt's "List" five examples are said to have been killed in the same week, in various parts of the county in the autumu of 1826 ; and in 1831, Mr. Lubbock states that "many were killed during August and September." Mr. Rising also informs me that he once shot six in one day, in his marshes at Horsey, and

* Under the head of great snipe, in Daniel's "Rural Sports" (vol. iii., p. 182, note), the author states that "a gentleman of Yarmouth, in September, 1805, shot a snipe of the astonishing weight of fourteen ounces," which is as hard to credit as the story of the Norfolk woodeock that weighed twenty-seren ounces. 
much more recently Mr. T. W. Cremer, of Beeston, near Cromer, killed five in one day out of a turnip field in that neighbourhood, which he describes as rising slowly, like woodcocks in the open, and spreading their tails.* Between the 6th and 19th of September, 1856, a bird-stuffer, at Norwich, received five specimens from the vicinity of Hickling and Horning, two of which were killed at one shot on a barley layer; and in September, 1862, a more than usual number were shot in the neighbourhood of Yarmouth, but it is somewhat remarkable that in the autumn of 1868, when, as shown by the various records in the "Zoologist" (pp. 1422, 1460, and 1461) and other journals, these birds were extraordinarily abundant in the south of England, $\uparrow$ I could not ascertain that more than two, or three examples at most, had been killed in this county.

This species is at once distinguishable from the common snipe, by the under parts of the plumage being barred throughout, the lower parts of the body in Scolopax gallinago being pure white. Besides this marked difference, however, the legs are somewhat stouter in the great snipe, and the beak shorter in proportion to the size of the bird, whilst the number of the tail feathers is sixteen $\neq$ instead of fourteen as in the common snipe; but I cannot quite agree with some authors that the eyes are proportionately higher in the head. The whole bulk of the bird, comparing

* By some authors this bird is described as uttering no sound on rising, but Selby remarks that "when flushed" the great snipe generally utters a cry in some degree similar to that of the common species, but shorter and hoarser.

+ Selby speaks of their being unusually plentiful in the year 1826, which, like 1868, was a very dry and warm season.

‡ Mr. E. H. Rodd recorded in the "Zoologist" for 1868 (p. 1482) a specimen of this bird, killed at Camelford, Cornwall, with sereral others, which had eighteen instead of sixteen tail feathers. 
even females with males of the common species, is altogether larger, and its general contour is expressively rendered by the term "woodcock snipe," as applied to it in some parts of the United Kingdom.

Mr. Gould, contrary to the statement of many authors, speaks positively as to the male of the common snipe being larger than the female, having arrived at that conclusion after dissecting a large number of specimens, and this rule, no doubt, applies to the great snipe as well. His drawing, also, of the great snipe in his "Birds of Great Britain," exhibits the marked difference in plumage between the adult and immature plumage; the old birds having the four outer tail feathers on each side pure white, crossed with two or three bars of square black patches, on the outer webs only, from about the centre to the base of each feather; and the secondaries and wing-coverts are also margined with conspicuous bands of white. From these markings, which are wanting in the young birds (their tail feather's being crossed with various shades of brown),* I am enabled to state positively that with very rare exceptions indeed, the great snipes killed in this county are all in immature plumage; most probably birds of the year. I have never seen more than two adult birds obtained on our eastern coast, one in my own possession, killed at Rockland, on the 17th of August, 1859, which was brought to me by a Norwich birdstuffer as

* Yarrell states that the "young birds in their first autumn have short beaks, and fewer, if any, white outside tail feathers;" but an immature male bird in my collection, which weighed seven and a half ounces, has the outside tail feathers barred across both webs almost to the tips, which are white; and the beak measures two inches and five-eighths; if anything exceeding the length of the beak in my adult specimen, also a male. The beak in an adult female of the common snipe, shot from the nest, measures a little over two inches and five-eighths. 
a curious variety, and the one before mentioned in Mr. Master's collection, procured in the spring of the year.

Messi's. Frederick and Perey Godman, in a communication to the "Ibis" (1861, p. 87), state that of several nests found by them in 1857, in a marsh at Bodö,* in Norway, between the 21th and 27th of June (nearly a month after the arrival of the birds) the egros, four in number, were deposited in a slight hollow scraped in the surrounding moss, usually "on the edge of a small lillock quite open," and with neither grass nor leaves in them; but in one instance, and one only, they found that the sitting bird persistently covered itself with moss, as a protection, no doubt, against the prying eyes of the magpies and crows, as well as other dangerous bipeds. An instinctive act very similar to that of the woodcock before noticed, which, by way of concealment, endeavoured to bury itself in the leaves.

\section{SCOLOPAX GALLINAGO, Linnæus.}

\section{COMMON SNIPE.}

When the veteran sportsman, whose experience dates back to the close of the last century, dilates on the snipe shooting exploits of his early days, by some, perhaps, the old man's tale may be listened to merely with courteous incredulity; but those who have marked the marvellous changes effected within their own recollection by drainage and cultivation, will receive the

* Mr. Alfred Newton informs me that in 1864, only seven years afterwards, he found this marsh had been completely drained, a striking instance of the destruction of the breeding places of various birds which is going on all over the world.

$2 R$ 
testimony of such a witness with no ordinary interest. It would be needless here to repeat the picture I have drawn in the introduction to this work of the condition of Norfolk some fifty or sixty years ago, as compared with its present state as a great agricultural county; but the changes which have gradually though extensively prevailed throughout that period, will sufficiently account for the very considerable diminution in the number of snipe that are now met with in autumm, both resident and migratory. It must be remembered, however, that whilst, within our own boundaries, the western fens retain scarcely any of their original features, and the fowler's occupation is gone in the now cultivated "Marshland;" that whilst in the "Broad" district the snipe-grounds have been everywhere curtailed by extensive drainage-the drier marshes of former days being now arable land, and the more swampy portions rendered "too good" for snipe; that whilst throughout the county the enclosure and cultivation of heaths, commons, and other waste lands, have deprived the snipe, the lapwing, and the redshank of many thonsand acres of their former haunts, the same indications of an advanced civilization are apparent elsewhere.* Such

* Mr. Alfred Newton tells me that at Barnham, near 'Thetford, and bordering on this county, on the property of the Duke of Grafton, there was some five and twenty years ago, a small but singularly productive breeding-ground of this species. It consisted of a piece of low land, only a few acres in extent, lying on the west side of that parish midway between the Elveden boundary and a slight rising ground called Hunhill. The water from a perennial spring forned a little stream which wound round and about for a long way before it made its escape, and after much rain overflowed the whole spot, whereon peat had formed, and in consequence there grew thickly such regetation as commonly flourishes in similar places, while all around the soil was dry and sandy, thinly clothed with short grass studded with scrubby heather and furzo bushes, hardly frequented by any birds. But this little 
has been the ease in other counties, and particularly in Huntingdonshire, where the once celebrated Wittlesea Mere now waves with corn crops instead of reeds. Yet, when snipes bred numerously in those fens, * the migratory flights in autumm, combined with others performing the same southward movement, afforded good sport in our own marshes, under certain conditions of wind and temperature. Still further afich also, the great increase in the number of grouse-shooters in Scotland, of late years, will account for a considerable number of snipe bagged in the early part of the season which would otherwise pass on to us with the first fiost.

oasis, not much larger than a good sized garlen, was evergreen, and all the year haunted by snipes-never more so than in the breeding season, when, perhaps it is no exaggeration to say that, there may have been from a dozen to a score of pairs. About the time that the late Duke of Grafton succeeded to his father, the farm on which the Hunhill-lows are was let to a new tenant, who, being of a more enterprizing character than his prodecessor, began the usual course of agricultural improvements. A drain was cut straight from the spring, and a direct ontfall made for the water instead of its being allowed to find its own way, and in so doing to promote the growth of the rough herbage. Sheep, even breeding ewes, came to pasture in summer without fear of the rot, and in winter black cattle grazed without a chance of being bogged. The surface soon became almost as smooth as a well kept lawn, and the snipes of course ranished.

* It would appear that formerly in the "Fen" district, many more snipes were snared than shot, being thus of more value for the table. The snaring was generally practiced during hard weather, when there were but few runs of open water. The snares were of horse-hair, and set wherever the ground was " soft." This custom, however, has never, I believe, prevailed much in the "Broad" district.

+ Mr. Lubbock, in his "Fauna," mentions an excellent letter on British snipes, under the signature of "H. V.D." in the second Folume of "Loudon's Nagazine of Natural History" (p. 11.?), which, according to a note in Thompson's "Birds of Ireland" (vol. ii., p. \& $\mathrm{R} 2$ 
Nor is there much reason to doubt that both in the north and south of Europe the numbers of this species, as well as of the woodcock, have been sensibly diminished through the craving for sport of the irrepressible gumner,* especially when prolonged till late in spring.

MIr. Lubbock remarks, that the snipe "has, perhaps, diminished less in numbers than most of the marsh birds," and this may still be said of it after a further interval of five and twenty years; since, so long as the broads maintain any portion of their natural condition, the "whole" snipe, as it is provincially termed, to distinguish it from the "half" or jack snipe, will continue to be met with in greater or less plenty according"

270 ) was written by no less an authority than the late Mr. Yarrell; and is here specially worthy of notice, since his remarks were founded "on obscreation and experience, as a naturalist and sportsman, in the eastern part of the county of Norfolk." At one period of his life that distinguished Oruithologist was a constant visitor to Yarmouth and its neighbourhood, where he died on the 1st of September, 1856. In this instance, therefore, in quoting Yarrell, I must be understood to refer only to the above letter, with regard to the arrival of snipe in our marshes early in the autumn. But writing, it must be remembered, as long since as 1829, he says, "in the latter part of August, we hare a much greater number of snipes on our marshes than were bred in the neighbourhood. This I have constantly regarded as a congregating and migration of the snipes bred in the northern part of this kingdom." Those arriving in September and October, particularly after gales from the east and north-east, he always regarded "as bred in foreign countries."

* A correspondent in the "Field" of April 8th, 1865 (p. 233), writing on the "progressive and rapid deterioration of snipe shooting in Ireland," attributes it not so much to drainage as to "guns for the million, no game certificate ever asked for, save, perhaps, in some rare instance from a gentleman, - the facility of transmitting game from all parts of the country to the large towns and the metropolis; and, consequently, a ready sale and high price for the contents of the poacher's pocket." The writer also supports his theory with some very forcible evidence. 
to the season. The same author also states from his own observations in former days, that "a very small number, compraratively speuking, are bred in the Norfolk Fens," and such, no doubt was always the case, inasmuch as the snipe, like the dunlin, curlew, and other marsh and shore-biris, seems to resort, as in Scotlind, to elevated situations for breeding purposes; * even though some maty ammally remain in the drier portions of their winter quarters. At present they are found breeding throughout both the "Fen" and the "Broal" districts, but their numbers depend much upon the weather, being most abundant, according to my own observations, after a cold spring, with a prevalence of north-easterly gales, at the period of their vermal migration. At such times they arrive here later than usual, and if unable for some days to continue their passage, the urgent necessities of parental duties oblige them to seek in our marshes a retreat for their expected offspring. This was particularly the case in 1860, when a heavy fall of snow occurred as late as the 22nd of April, and then an unusually large number of snipes remained with us to breed. It not unfrequently happens, however, that just after their first eggs have been laid and the old birds have commenced sitting, a considerable rainfall, or an extraordinary high tide on the coast, so floods the marshes that both nests and egg's are destroyed, whilst the snipes, thus driven from their adopted home, leave us altogether, and the prospects of a good breeding season are entirely changed. Of course by far the largest number are bred on the broads and marshes bordering

* In the Hebrides, Macgillivray states that their nests are found in various situations; often in the grassy pastures, but more frequently on the unfrequented moors, from the level of the lakes to the height of two thousand feet. 
on the Bure and the Ant, where as yet the whistle of the locomotive is unknown, and a country wild in the extreme, and for the most part preserved, offers the most favourable conditions. About Horsey, Hickling, and Heigham Sounds, and again at Horning, Ranworth, and Hoveton, whether in summer or winter, they are mostly abundant; and on the Yare, owing to careful preservation of late years, many still remain, in favourable seasons, in the neighbourhood of Surlingham, and some in the marshes about Langley and Buckenham, which, though now drained by steam, are specially mentioned in Lubbock's "Fauna" as more frequented than other's by snipes in the breeding season "being there protected from the unfair system of "egging." " Indeed, the wide extent of marshes which the railroad now traverses, with but little intermission between Norwich and Yarmouth, and where, in Sir Thomas Browne's time, the ruff and reeve bred freely with other grallatorial species, was formerly reckoned the best snipe ground, in Norfolk.

Besides the above localities, a few scattered pairs may be found breeding in almost all parts of the county, wherever favourable spots present themselves. To the western fens, though in greatly decreased numbers, they still resort ammally in spite of all changes, as also to that small chain of fens bordering upon the river Thet, in the south-western part of the county, and the swampy margins or islands of the "Meres," which are chiefly situated in that neighbourhood. At Scoulton, near Hingham, many are bred annually on that portion of the "hearth" or island, in the centre of the Mere, which is least frequented by the blackheaded gulls. A few "wet" commons, also, still happily preserved to us, form a summer habitat for this species, with the lapwing and redshank. Flordon Common to the south-east, on a tributary of the Taes; Walton 
Common, near Westacre; Lexham Common, and sereral smaller ones on the Nar and other streams in that portion of the county; and East Ruston, to the north-east, within three miles of the sea at Happisburgh, may be specially noticed. Both for the home-bred and migratury snipes these rough waste lands lave peculiar attractions, the soft mossy turf being intersected by small streamlets, and in the more swampy portions a dense growth of reeds and sedges margins the little "pulk" holes or pools of water. East Ruston Common has also peculiar features, inasmuch as one portion, bordered by a ruming stream, is covered with small bushes of sallow and birch, where woodcocks as well as snipe are frequently met with, and the rivulet is a favourite haunt of the green sandpiper. The rest of the ground, from which the turf is cut, consists of alternate ridges or" "seams" of peat, and wide trenches in which the water is generally more or less deep; and as this constitutes the best feeding ground for the snipes, the sportsman has to pick his way along these narrow walls of peit, with the certainty, if unaccustomed to this mode of progression, of overbalancing himself, one side or the other, at almost every shot. Yet here, in a grood season, from three to four hundred snipes have been killed, even of late years; and when I visited it in August, 1865, about five and twenty couples had been shot up to that time; all bred around the small broads and swamps of that wild neighbourhood, no foreign snipes having appeared up to that time.

The snipe is an early breeder, and the return flights which risit our marshes on their northward passage, usually make their appearance about the second or third week in March; but in mild seasons, as Mr. Lubbock states, "parties are often found skimming round the edges of the broads, and alighting on the masses of decayed weed and floating sedge, so early as the middle 
of February.* If detained for some days by contrary winds, there is usually good sport at this time of year, although the main body soon pass on again to their northern homes; but the custom which, I am sorry to say, very generally prevails of shooting snipe even as late as the first and second week in April, cannot be too strongly deprecated, inasmuch as the females are then either heavy with egg or actually engaged in incubation; whilst many that would remain to breed in our marshes are thus slaughtered or driven out of the county. Surely the proprietors of our local snipegrounds, who have the power of preserving in their own hands must, on reflection, see the fallacy of thus killing the old birds in spring, when, if allowed quietly to establish themselves for the summer, their progeny would afrord more certain sport in the course of the following autumn. Before long, it is to be hoped, an act may be passed to preserve all this class of birds in the breeding season, and having seen the effect during the last few years of the protective system, both at Hoveton and Surlingham, I have no doubt as to a favourable result. On the latter broad, during the first week of August, 1865, an unusual number having remained to breed, I flushed between thirty and forty couples on one small marsh. Three, which I shot, proved to be young birds of the year in fair condition, and quick on the wing, but up to that time, the marshman assured me, no foreign flights had made their

* Yarrell states that their return in the month of February or Mirch, is regulated by the same atmospheric influences that cause certain wild flowers to bloom earlier or later in different seasons, and adds, "by attending to these coincidences a Norfolk sportsman will rarely be disappointed in his expectations of amusement at this time of year." The usual term of re-migration he considers to be between the 11th of March and the end of that month. 
appearance. These homebred birds, however, must not be left too late into the autumm should a dity or two's shooting be contemplated, as with the first frost they quit our marshes for the south, to be suceeded only by the usual migratory flights.

As early sometimes as the middle of MIarch, but generally a reek or so later, the strange "drumming", or bleating noise* of this species when on the wing, indicates the commencement of the nuptial season, and from that time all persecution should cease, even though, with regard to the time of incubation, the snipe is rery irregular. A cold backward spring, or the first eggrs having been taken, or destroyed by a sudden flood, will make all the difference, but those which are fortunate with their first brood, have no doubt a second hatch, as the "drumming" may be heard at times as late as the end of July, and I have seen young birds, still in the down, in the middle of August. Mr. W. R. Fisher recorded in the "Zoologist" for 1843 (p. 248), the fact of two snipe's eggs having been brought to Yarmouth for sale, from a nest which contained four, as early as the 1st of April, $\dagger$ and I hare received them myself, quite fresh, on the 8th

* Hence the name of "heather bleater" by which the snipe is commonly known in Scotland, and according to Thompson, Gaelio and Irish words are applied to it signifying "air-goat," or "kid of the air." In France it is termed "chèvre volant;" and Mr. Alfred Newton tells me that in Lapland it is known by a name which signifies "ram of the sky."

† In the "Field" of 1867 (p. 275), Mr. H. M. Upcher, of Sheringham, states that a freshly killed snipe dissected by him, on the 30 th of March, contained a perfect egg richly coloured and ready for exclusion. In the "Zoologist," also, for 1868 (p. 1256), Mr. F. Boud mentions a very early nest of the common snipo in Sussex. The hen bird was shot on the 4 th of April and her four eggs taken. The breast featbers eren then indicated that she had been sitting some days. 
and 16th of that month, as well as young in their first down by the 3rd of May. I have also a couple of nestlings with their wing feathers nearly complete, though still with much down left amongst the new plumage, which were taken at Surlingham on the 19th of June; and by the 16th and 21st of July, Mr. Dowell has found them fully grown.* At this time, as Yarrell states, both "old and young quit their breeding marshes in common with other fen birds, and betake themselves, in family parties of six or seven in a flock, to marshes which have been recently mown."

The nest, with its usual complement of four large eggs, $\dagger$ is placed either in a tuft of grass or rushes, in some dry portion of the marsh-a mere hollow in the ground, lined with coarse grasses, or on a raised "tussock" similarly concealed, and is not unfrequently situated near a run of water. The young, when disturbed in their downy state, instinctively seek shelter in any slight irregularity of the ground. In this stage, as is the case more or less with all the waders, young snipes are the prettiest little objects imaginable, their russet coats in various shades of brown being relieved with greyish markings on the upper parts, the whole assimilating in a marvellous mamer to the herbage which surrounds the nest. A female in my collection, shot from the nest, exhibits the grey colouring on the throat and sides of the face, which, according to $\mathrm{Mr}$.

* Yarrell states that in 1829 he "killed young snipes, strong on the wing, as early as the last week in May; but in other years seldom before the 6th of June.

+ Low in his "Fauna Orcadensis," states that he has several times found six eggs in the same nest, but this Mr. Hewitson accounts for by two birds having laid in one nest, as is not unfrequently the case with other species. The snipe's egr is so large for the size of the bird that it would be almost impossible for it to cover more than four. 
Gould, in his "Birds of Great Britain," is assumed by this species in the breeding season.

Often have I watched by the half hour together, till my eyes fairly tired of looking up into the bright smmy sky, the strange "play" of the snipes in spring and summer. Sometimes one only, at others several may be seen at a considerable height, now curving upwards with a wide circling flight, now rapidly falling from their highest pitch with quivering wings and outspread tail, whilst simultaneously with the downward movement, and then only, a tremulous buzzing sound falls upon the ear, which ceases the moment that the bird, recovering itself, ascends once more. The same performance is repeated again and again, sometimes for hours, and occasionally the snipe takes so lofty a flight as to be scarcely visible to the naked eye; but in the final descent the flight is extremely rapid and making a slight detour as it nears the ground, the bird drops abruptly into the sheltering herbage of the marsh or reed-bed. From the earliest dawn this sound, so peculiar to our marshy districts, and associated always with the wail of the lapwing and the redshank's whistle, may be heard at intervals throughout the day, but towards evening many more seem to indulge in this resonant flight; and still more strange is that buzzing in the air, if heard after dark, with the birds of course invisible even in a starlit sky. I was first aware of this nocturnal habit when staying near Horming Ferry, in the middle of April, 1860 (an unusual number having, as before stated, remained to breed in this county), but then, every evening, as late as nine or ten o'clock at night, the noise of the snipes was as incessant, and remarkable, as a frog's' concert. It is noticeable, however, that this peculiar action is not altogether confined to the breeding season. Mr. Blofeld, of Hoveton, an unquestionable 2 s 2 
authority in such matters, assures me he once heard a snipe drumming in the depth of winter, and on drawing the attention of his marshman, William Hewitt, to what he then considered a very strange occurrence, the old man assured him that he had remarked the same thing on several occasions, and that he regarded it as a sign of stormy weather; which in that instance proved correct. I think there can be no doubt that this is a purely "amatory signal," but just as some birds sing in autumn or winter, so cock snipes will, no doubt, at other than breeding times.

There had been various attempts to account for the way in which the neighing or drumming was produced, but no one suceeeded in doing so satisfactorily until $\mathrm{Mr}$. W. Meves, the conservator of the Zoological Museum of Stockholm, discorered that it was due to the vibration of the stiff webs of the outer tail-feathers, caused by the action upon them of the air as the bird descends rapidly in the course of its "play;" the sound, as I have before remarked, being heard only as the snipe falls.* That it is not produced in any way by the throat is evident from the fact that the ordinary cry of the snipe, which Selby not inaptly likens to "the word chissich lispingly pronounced," has been heard simultaneously with the drumming: noise; and Mr. Harting ("Birds of Middlesex") on one occasion, was enabled to satisfy himself that the beak remained closed at the moment the drumming sound was perceptible. Mr. Meves thus explains the circumstances which led to his very remarkable discovery. "The pecaliar form," he says, "of the tail feathers in some foreign species, nearly allied to the common snipe;

* Another sound, or properly speaking, note, is occasionally heard as the bird ascends, which Yarrell likens to the word "tinker, tinker, uttered in a sharp shrill tone." 
for instance in Scolopax javensis, encomraged the notion that the tail, if not the only cause, is in a cousiderable degree concerned in the production of the sound. On a closel examination of the tail feathers of our common species, I found the first outer feather, especially, rery peculiarly constructed; the shaft uncommonly stiff and sabre shaped; the rays of the webs strongly bound together and very long, the longest reaching very nearly three-fourths of the whole length of the web, their rays lying along or spanning from end to end of the curve of the shaft like the strings of a musical instrument. If we blow from the outer side upon the broad web it immediately vibrates, and the sound is heard, which, although not so loud, resembles very exactly the well known neighing. In order to convince myself fully that it was the first feather which produced the peculiar sound, it was only necessary for me carefully to pluck out such a feather, fasten its shaft with fine thread to a piece of steel wire a tenth of an inch in diameter and a foot long, and then to fix this at the end of a four foot stick. If now I drew the feather, with its outer side forwards, sharply through the air, at the same time making some short movements or shaking of the arm, so as to represent the shivering motion of the wings during flight, the neighing sound was produced with the most astonishing exactness. If I wished to hear the humming of both feathers at once, as must be the case in the flying bird, I found this also could be managed by a simple contrivance. I take a small stick and fasten to the side of the smaller end, a piece of burnt steel wire in the form of a fork; then I bind to each point a side tail feather; then bend the wire so that the feathers receive the same direction which they do in the spreading of the tail as the bird descends in flight; and then with this apparatus, I draw the feathers through the air as before. Such a sound, but 
in another tone, is produced when we experiment with the tail feathers of other linds of snipe. But in Scolopax major, S. capensis, and S. frenata are found four humming feathers on each side, which are considerably shorter than in the species I have been speaking of, Scolopax javensis, has eight feathers on each side, which are extremely narrow and very stiff. Since in both sexes these feathers have the same form, it is clear that both can produce the humming noise; by means of experiment I have convinced myself that it is so."* The late Mr. John Wolley, an undoubted authority, saw this experiment repeatedly performed, and was perfectly satisfied that this mode of explaining the drumming sound was the correct one, as indeed any one may be who makes trial for himself of $\mathrm{Mr}$. Meves's experiment. In support, also, of Mr. Meves's assertion that the act of drumming is common to both sexes, Mr. Harting informs us that a pair of suipes flushed from their nest, "continued to fly round in circles making this peculiar noise for nearly half an hour." Both birds were heard to "drum" distinctly and separately, and thus we may account for more being heard towards evening than during the day, as the hen birds would then leave their nests for awhile, and join with their mates in the same sportive flight.

As a rule the first flights of snipes from the north of Europe arrive about the middle or end of August, for I imagine that those mentioned by $\mathrm{Mr}$. Lubbock as appearing at the end of July, were bred much nearer home. In the early part of the season they are fiequently to be found scattered over the cultivated lands, $\uparrow$

* "Proceedings of the Zoological Society," 1858, p. 199 et seq. Extract printed also in "Zoologist" for 1858 (p. 6244.)

$+\mathrm{Mr}$. Cordeaux, speaking of the earlier arrivals of snipes in North Lincolnshire ("Zoologist," 1868, p. 1030), remarks, "We 
or the sedgy margins of pit holes and ditches, as well as in such marshes as are then sufficiently moist. They have also a decided preference for such as have been frequented by cattle during the summer months, their dung affording much insect food. The low lands near the salt marshes, on the coast, also afford good sport at times when the snipes are first over, and in such localities, at Blakeney, Mr. Dowell has known as many as twelve couples killed to one gun in a day. These, however, soon pass on to the southward to be succeeded by others throughout September, but it is seldom that any number are bagged until the main body of the migratory snipes disperse themselves over the broads and marshes in October and Norember. As Mr. Lubbock remarks, "their abundance and their stay are regulated in great measure by the wind and the mildness or severity of the weather. The best seasons for snipe-shooting are those in which moderate easterly or north-easterly gales occur at intervals during September, October, and November. Should too long au interval occur without such wind, the snipes, when it comes, pour in upon us in great numbers, but generally depart again in a few days." Usually, as far as my experience goes, the latter month is the most fivourable, and on the broads, especially, they are then more accessible in boats, * the reeds having been cut, or

at first seldom find them near water, almost invariably in dry situations, in pasture land amongst the long grass, or on stubbles."

* At such times, as Yarrell, in the article before mentioned, states from his experience of the broads, "they resi on beds of watercresses and the broken remains of Scirpus lacustris (which had previously been cut by the marshmen, under the name of bolders, for chair bottoms); and the Typha latifolia (vulgo gladdon), and Sparganium ramosum (vulgo black-weed), which are used by coopers to put between the staves of casks; on the floating remains of these and other aquatic plauts they lie in great numbers." 
"laid" in places by the frost, and many couples may then be flushed from the "hoves" or mown pathways bordering the reed-beds; as well as on the surrounding marshes, which by that time, as feeding grounds, are in much better condition. It is often difficult, however, to account for the sudden arrival or departure of these birds, here to day and gone to-morrow, and every sportsman knows by experience how rarely a good day's sport is obtained amongst many blanks in the snipe shooting lottery. How consolatory after a hard day's walking, with scarcely a shot to keep up excitement, to hear from the marshman the old, old, story, "Lor! Sir, if you'd only been here yesterday, why that there marsh was pretty well all snipe." Nor have you even the satisfaction of doubting his word, when you find that most eligible locality beaxing "mute" evidence to their recent abundance. And thus, at times, even at the present day, very large bag's may be made when a good shot happens to hit upon the right day.

Snipes, however, without leaving us altogether, appear to be constantly shifting their ground under "slcyey influences," a sudden flood in the low lying marshes often driving them in "wisps" into the turnipfields, or occasioning them to congregate in unusual numbers on such marshes as may chance to lie higher and drier than the rest. On the $23 \mathrm{rd}$ of November, 1853, a fair sprinkling of snipes having been reported in that fine district, I was asked to shoot with a friend at Ranworth, but although we walked all the best ground, the waters had so risen on the previous night that searcely a bird was to be seen, and up to one o'clock we had had only two wild shots. As a last resource it was suggested that we should try some marshes on a higher level at Horning, even though much time would be lost in going so far. As it turned out we were amply repaid for our trouble. No sooner had we 
landed on one marsh, of no great extent, than the snipes rose on all sides, not in a body but two or three at a time. If we walked on too quickly they rose behind us; if the dog fetched one he sprang several more, so reluctant did they seem to take wing at all, and their numbers were so extraordinary and so unlooked for, that the eye became altogether confused, and it was difficult to determine which to shoot at first.* In the excitement of this novel scene, I well remember missing five shots in succession with my first barrel, and killing them all with the second; and though in a very short time we had secured twelve or fourteen couples, had I been as good a snipe shot as my companion, and daylight hud lasted, we might easily have bagged eighteen or twenty couples.

It has been said that snipes are not in condition till after the first frost, and certainly some of the weightiest birds I ever handled have been killed during the most severe weather. This however, arises from the fact that although a severe frost compels the main body to seek a milder climate, $\dagger$ yet a good many will betake themselves at such times to the upland springs or sedgy banks of meadow drains and rivulets, and in these localities, even with a deep snow on the ground, several couples may sometimes be met with, both common and jack snipes, and always, under such circumstances, in high condition. In January, 1861, and again in the winter of 1866-67, during the extraordinarily sharp weather, which at that time visited us for many weeks, when nearly all the denizens of the broads had been

* A somewhat similar occurrence is narrated in Thompson's "Birds of Ireland" (vol. ii, p. 262.)

+ It is probable that at these times the snipes take a westerly as well as southerly direction, which would account for the unusual numbers met with by Mr. Harry Blake Knox, in the county Dublin, in January, 1867. Seo "Zoologist," 1868 (p. 1192). 
frozen out, and even such birds as remained in our fields and hedgerows were dying from cold and hunger, some of the weightiest snipes I ever handled were killed near a spring head in an inland situation. In the neighbourhood of Norwich the low meadows at Thorpe, Lakenham, Cringleford, Earlham, Bowthorpe, and other places, are all more or less likely under such circumstances; although too much drained to afford at other times, the sport which in former years could be had there throughout the scason.* The wet commons before mentioned, as well as the marshes bordering on the coast, both salt and fresh water, are also much frequented during the first day or two of frost. In the first week of December, 1862, during severe weather, an immense number of snipes were found scattered orer the county, and in somewhat unusual localities.† Seventeen couples and a half were killed off the "ronds" $\ddagger$ only on

* Daniel, in his "Rural Sports" (vol iii., p. 178), gives some interesting observations by a Norfolk gentleman "upon the times of the snipe's appearance in the vicinity of Norwich," both in spring and autumn; and in these notes made in the years 1800 and 1801, Moushold-heath is mentioned as a locality frequented by them. Even within the last forty or fifty years good snipeshooting could be had, about Trowse and Lakenham, close to the city, the winding course of the Yare presenting many tempting spots for these birds in the various islets, osier-carrs, and reedbeds, whilst the surrounding meadows were not then "too good." Yet here-except in frosty weather, when I have killed three or four couples in a morning ont of the marsh drains, a suipe is rarely seen at the present time.

+ In his "Ornithological Notes from the Scilly Islands," "Zoologist," 1865 (p. 9452), Mr. E. H. Rodd describes the snipes during frost and snow, as "feeding with the poultry in front of the drawing room window, **** and it was a pretty sight to see an old turkey cock pursue a snipe by the Abbey Pool."

\& These wide and swampy margins to the river (called in the western part of the county "washes"), lying between the water's edge and the raised bank which protects the adjoining lands 
the river Bure, near Yarmouth, and many others were found at Earlham, Heigham, and Markshall, and even near the Foundry Bridge within the bounds of this city. On the broads they were deseribed as appearing in immense "wisps,"- "humdreds in a lump" as one marshman described them. Again in 1867, after severe rime frosts, between the 26th and 30th of November, I counted over thirty couples of snipes in our fish-market, including four couple of jacks, all of which had been bronght up to Norwich in one day, and a man who had shot the chicf portion of them, stated that they had been killed on the Bramerton marshes, where he believed there were hundreds, as he had never before seen anything like such numbers.* Marshmen also have told me at different times, of snipes sitting in large "wisps" on the broads during" a white frost or in snowy weather, crowding together in bunches on the broken down reeds, and affording a rare chance for a big gum.† The great difficulty of observing a snipe on the ground amongst the coarse herbage, is known to all sjortsmen, but from long habit our broadmen are so quick sighted, that it is not unusual for them to distin-

from inundation, aftord good lying for the snipes when the dense growth of sedge and other coarse herbage has been mown in autumn, and afford very good sport at times; the bag including rails and water-hens as well as snipes.

* It should be here mentioned, also, that on the 1st of Decomber, within a day or two of the time these snipes appeared, our coast was visited by a fearful gale from the north-east, causing an almost unprecedented ligh tide at Yarmouth, and a consequent flood over the whole of that neighbourhood; which resulted in great damage to property and loss of life at sea. The weather had previously been unusually wet with much fog and occasional storms of hail and snow.

+ It was probably under such circumstances that, as related by Daniel in his "Rural Sports," the Duke of Marlborough's gamekeeper once killed twenty-two snipes at one shot. 
guish a bird in some spot where, even though pointed out to him, the novice may look in vain. I never remember to have detected a whole snipe in a marsh before its warning cry of "scape, scape" on rising attracted my notice, but I have caught sight of jack snipes sitting close to my feet more than once; and occasionally, when rowing by the side of a reed-bed on the broads, the bright eye of a snipe, squatting close to the water's edge, has suddenly caught my own, though otherwise, even within a yard of me, it would have passed umoticed. During frost and snow, however, when pinched with the severity of the weather, I have more than once come upon a snipe feeding by the side of an open stream, too busily engaged in "boring" to be aware of my approach. Mr. Harting also states in his "Birds of Middlesex" that on one occasion having surprised a snipe under similar circumstances, it squatted down in the water as soon as it was aware of his presence, and was only flushed at last by a pebble thrown at it. The food of this species consists chiefly of earthworms, with insects and small mollusca.*

With snipes as with woodcocks, it is difficult to arrive at any satisfactory estimate of the numbers that formerly visited this county as compared with the present time. $\dagger$ Then, as now, exceptional cases occurred

* In confinement they will readily eat bread and milk, and on this food Mr. Edward Newton reared some, eaught when half grown, till they were fully fledged. They thrived admirably until sent to the Zoological Gardens, when they immediately died.

† It is somewhat singular that in the L'Estrange " Houschold Book" snipes are but once entered, "Itm $\nabla$ snypys," but no price given, and they were probably too common for Sir Thomas Browne to notice them in his "List." In the "Northumberland Household Book" they are ordered to be bought "for my Lordes owne Mees at Pryncipall Feystes so they be good, and after iij a ja."; a pretty good evidence of their abundance at that time. 
of enormous flocks visiting us from temporary causes, and we have fortunately a few records of the numbers killed on such occasions; but these are, of course, no guide as to the bags then made in any average season. From conversations I have had, however, with several old sportsmen on this point, I believe that where forty or fifty years ago, twenty, or five and twenty, couples a day was reckoned good sport (occasionally as large a number falling to one gun) at the present time, even on the best ground, ten couples would be reckoned a good bag and four or five an average quantity. At Surlinghim, Mr. Robert Pratt, who has had considerable experience in such matters, assures me that although during the last few years the broad and surromding marshes have been carefully preserred, they have nothing like the amount of snipes in the autumn and winter that they had fifteen or twenty years ago. This he attributes to certain tidal influences caused by the opening out of Yarmouth Bridge, by which the waters rise and fall more rapidly than they used to do, thus suddenly flooding out the snipes with an exceptionally high tide, and again receding too soon to leave the marshes in a fit state for feeding. This also applies more or less to other localities where, prior to the drainage system of the present day, the very gradual subsidence of the waters, after a wet season, left the marshes in the most attractive condition for snipes; whilst many of them have now become too dense and mossy. In October, 1852, after repeated visits with but small results, a good shot bagged eighteen couples in one day on Surlingham broad, but since then the largest bag I know of, on the same ground, has been twelve and a half couples, and between five and six is considered fair shooting. In the season of 1862-3 over four hundred snipes were killed to an average of three guns, about Surlingliam and Rockland; and still more 
recently, as many have been shot on the opposite side of the river, about Brundall, Strumpshaw, and Buckenham; but this can only be effected by residents, shooting almost daily so long as any snipes are to be found.*

The following are a few cases in which exceptional numbers have becn lilled in Norfolk, as recorded by local authors, or gleaned from the "hearsay" evidence of sporting friends :-

The Messrs. Paget, in the introduction to their "Slketch," state that in the winter of 1829, five lnumdred snipes, with a proportionate number of plover and wild fowl, were brought in to a Yarmouth gamedealer on one market day. A similarly remarkable occurrence is also given by Messrs. Gumey and Fisher in the Introduction to their "Birds of Norfolk," who state that on the 11th of December, 1844, five hundred snipes and eight hundred dunlins were brought to one dealer at Yarmouth; and on the 16th, two humdred dumlins and three hundred snipes. At Sutton, some eighteen years ago, Captain Rous killed over forty couples in one day to his own gun, and the marshman who was with him, merely taking the outskirts, killed fourteen comples. In the Langley and Buckenham marshes many years ago, when in fine condition, a single sportsman is said to have killed eighty couples to his own gun; and about five and twenty years back, I am told that Mr. Robert Fellowes lilled seventy-nine couples in one

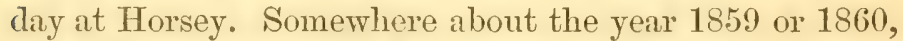
and in the month of November, $\mathrm{Mr}$. Dowell informs me that immense flights of snipes appeared on the

* The marshmen are usually aware of the arrival of the snipes in any large quantities, and, communicating at once with some neighbouring sportsman, he stands a fair chance of making a bag the next morning. An individual, however, from a distance, who probably camnot obey the summons before the second day, in all probability finds that the snipes have shifted their quarters. 
coast, in the neighbourhood of Holkham, and being met by a serere frost on landing, afforded extraordinary sport for two or three days. On the first day Lord Leicester killed seventy or eighty comples, either flying overhead or out of the small drains; on the next day his lordship and a gamekeeper shot about serenty-eight couples, and having written for Mr. Dowell, that gentleman on the third day killed eighteen couples, but by that time the greater bulk of them had leit the neighbourhood. As a further instance, also, of a sudden frost driving the snipes in large numbers to the inland springs and drains, MIr. Thomas Elwards informs me that some thirty years ago, when residing at Hapton, he lilled eightyfour couples of suipes in two days, which were scattered over the low lying meadows and common lands in that neighbourhood.

The following returus from his game books of some of the most firvourable seasons for suipe in that neighbourhood has been kindly supplied me by Mr. E. C. Newcome, of Feltwell:- In 1839 four hundred and twelve snipes were bagged. In 1841, six hundred and thirty-three-the best days in that year being September 6th, when Mr. Newcome and his brother killed fiftysix snipes, and October 2nd and November 20th, when the Rev. W. C. Newcome shot twenty-nine and fortynine snipes respectively. On the 14th of October, 18t3, the late Lord George Bentinck bagged twenty couples. On the 28th of September, 1851, the snipes being plentiful but very wild, the Rev. W. C. Newrome shot furty-five snipes; and in 1860 the total bag amounted to three hundred and seven.

From the Rev. J. Burroughes I learn that during: liis long experience, both as a naturalist and sportsman, of the habits of our marsh-birds, he has in two or three instances known of extraordinary migrations of snipes. 
On one occasion at Wheatacre Burgh, near Haddiscoe, where the birds kept on in continuous flights across the country, as larks are seen to do in southern counties, taking one particular course, and thus passing on for several hours. At another time, some fifteen years ago, with snow on the ground, during a similar migratory movement of this species, near Buckenham Horse-shoes, the birds, in passing over a fence near a gateway, flew so low that some were even knocked down with sticks. He has also occasionally found them very plentiful on the ploughed fields, and has killed as many as five and a half couples in such localities.

The partiality for some particular spot is as marked in the snipe as the woodcock, and most snipe-shooters can recall some pit-hole, drain, or spring head, where invariably as the season came round a snipe (and more particularly a jack), could be found. If the soil is but suitable to their habits, any moist situation contents them, and I remember some years back a little swamp close to a residence at Hardingham, where snipes were always found in autumn. So confined was the space that, at the first shot, the "whole" snipes would rise in a "wisp," and two or three jacks would be flushed by close wallking. If revisited again in an hour or two they were sure to have returned to the same spot, and thus in two or three visits as many couples might be bagged in the day; but drainage, has, I believe, since accomplished what constant shooting failed to effect, and banished them for ever.

Some of my readers will probably remember that in 1858-59 a discussion took place in the columns of the "Field" on the question of snipes perching at times on trees or other elevations; and, in spite of the authorities then cited to the contrary by the naturalist editor of that joumal, I must still maintain that such is the case, and in support of my assertion could produce many 
witnesses, both marshmen and sportsmen, resident near the broads. It would seem, however, that this habit is confined entirely to the breeding season, all the instances I have heard of in this county having occurred in the summer months; and where a tree or a marshmill stands conveniently near the nest there is no doubt that one or other of the parent birds will occasionally settle upon it. Most frequently, I imagine, the male bird wlilst the hen is sitting.* Both Mr. Blofeld and his marshman, William Hewitt, assure me that they have witnessed this fact in several instances at Hoveton; and on one occasion, when sailing in the Norwich river, Mr. Robert Pratt, of Surlingham, observed a snipe perched on a mill sail near the shore, and a young lad with him at the time having shot the bird, sitting, brought it on board the boat. A relative of my own, the Rer. J. C. Matchett, well accustomed to the Broad district as an angler, as well as snipe shooter in former days, assures me that many years ago, at Ranworth, in the spring of the year, he saw a suipe perch on a "notice" board which stood on a marsh near the side of the river. Mr. F. Mills also, an observing naturalist as well as sportsman, informs me that in two successive years, when residing near Horning Ferry, he saw a snipe perch on the branch of a tree, and on the last occasion pointed it out to a friend who had been sceptical on the point up to that time. The gamekeeper, who has charge of the Gullery at Scoulton, has frequently seen a snipe perch on the summit of a

* It is possible, also, although I have no data to prove this, that it occurs only when the upper branches of the tree have been struck by lightning, or from other causes are bare of leaves; thus presenting, as in the case of the mill sails, a clear surface. Wo all know that swallows mostly, though not invariably, select the dead wood, near the summit of a tree, as a resting place for themselves and young. 
flagstaff, erected on a small island at that end of the "Mere" where the snipes always breed. On one occasion he saw a pair resting on it at the same time, and the black-headed gulls occasionally do the same. I could adduce other evidence, were it at all necessary, but though it so happens that I have never witnessed it myself, I am not the less positive as to the fact. It certainly is a rare circumstance, or it would scarcely have remained so long unnoticed by authors, but if the curlew, whimbrel, and spotted redshank, as stated by Hewitson, on his own and Mr. Wolley's authority, and the greenshank, as Mr. Alfred Newton informs me, regularly perch on trees, as well as redshanks on railings, during the breeding season; whilst green sandpipers, herons, spoonbills, and even cormorants, to say nothing of many kinds of ducks, frequent trees for breeding purposes-all of which one might say, if maware of their custom, were not at all likely to do so-what becomes of the "utter impossibility," as alleged, of the snipe committing a like breach of ornithological propriety.*

The common snipe varies much both in size and weight, the latter depending on the weather and the facilities for obtaining food. The ordinary weight may

* Mr. Gould does not refer to this point in his "Birds of Great Britain," but in a communication to "Land and Water" for February 1st, 1868, publishes a letter from Mr. W. H. Pope, Colonial Secretary of Prince Edward Island, in which that gentleman describes his successful attempt to shoot a snipe from off a tree; which specimen he sent to Mr. Gould, who had previously doubted his assertion that be had before seen "the snipe of that country (Scolopax wilsoni) perching on the tops of the highest trees." To this I may also add that the late Mr. Wheelwright, in his "Bush Wanderings of a Naturalist" (p. 100) states that the Australian snipes (Scolopar austrulis), which he there met with, "often perch in the tea-tree scrub," and that he had "twice killed them sitting on the bare limb of a large gum tree." 
be said to be about four ounces, but Mr. Lubbock states that out "of twenty-one comples lilled the 1st of December, 1829, the snipes being at that time in very ligh condition, six birds weighed five ounces each, two five and a half ounces each, and one bird within a hair of six ounces."

There is, however, as I have stated in my account of Scolopax major, a large race of the common species, of which several examples have been killed, to my lnowledge, in Norfolk. In my own collection is one of these, which I shot at Horning on the 23rd of November, 1853, when, as before stated, the flooding: of the low lands had caused extraordinary numbers to congregate on the higher level. This bird rose slowly and heavily like a woodcock, and uttered no ery, and when I shot it, I fully believed I had killed a solitary snipe, until I saw the white feathers on the under parts of the body. Two others of equal proportions were shot at the same time, which I regret to say were not preserved. In comparing my specimen, an adult female, even with a male of Scolopax major, it appears to stand as high on its feet, and measures abont the same in total length, but great as are its proportions as compared with ordinary specimens of the common species, it wants the somewhat woodcock aspect of the sulitary snipe. Like the common snipe it has only fourteen feathers in the tail, the white of the under parts is pure, but much barred on the flanks, and the rest of the plumage particularly rich in colour, with the dorsal stripes fairly defined. The most remarkable feature, however, is the beak, which measures exactly three inches and a quarter, whilst in a specimen of the solitary snipe the beak is only two inches and five-eighths, and the same in an average sized female of the common snipe. Being in rather poor condition it weighed only a little over six ounces, $\mathrm{Mr}$. 
Lubbock, however, mentions having seen on one occasion a gigantic snipe, which was then in the hands of a Norwich birdstuffer, and which weighed "very nearly eight ounces, although it was not unusually fat." As compared with the solitary he says "it was plainly a longer and a larger framed bird," but in all respects, except in size, "it was a veritable Scolopax gallinago." Curiously enough this bird was also shot near Horning Ferry. Mr. Gould, who has seen my specimen, considers that it may be the fully adult of his Gallinago russata, or "russet snipe,"* a name which he proposes in his "Birds of Great Britain" for this large race of snipes (of which examples have been killed in other parts of the United Kingdom), $†$ should it hereafter be considered worthy

* A specimen of this snipe, presented to the Norwich Museum by Mr. Robert Birkbeck ("British Series," No. 234b), and said to have been killed in the West of England, measures three inches and one-eighth along the upper mandible, but shows much less white on the under parts, and is altogether more russet in tint than mine, and is apparently a less mature bird.

† In the "Zoologist" for 1855 (p. 4704) Mr. E. H. Rodd, of Penzance, describes a "supposed new snipe," of which he had occasionally met with examples since the year 1834. His description agrees very nearly with my bird, although I could scarcely term the dorsal stripes narrower and " more obscure" than is usual in the common snipe; the rery dark tints of the back, the rich rufous of the neck and shoulders, and the more "striated" flanks, are all marked features in the Norfolk bird; and he also refers to the general richness of colouring in these snipes, even when killed in mid-winter. Mr. Gatcombe, of Plymouth, having examined two snipes similar to those described by Mr. Rodd, remarks, in the "Zoologist" for 1862 (p. 79:38), upon their peculiar features, but states that "the bill and tarsi especially appear very short when compared with the large size of the body," which in my specimen is certainly not the case. He adds, however, that "all sportsmen, who have killed the bird remark that it rises without noise." (See also the "Zoologist" for 1866, pp. 97 and 302 ; and the "Field," of November 28th, 1868). 
of specific distinction, but this is not, I imagine, at all likely.

Scolopa brehmi having the two outer tail feathers somewhat elongated, of which an example in $\mathrm{Mr}$. J. H. Gurney's collection was shot some years back, at Earlham, near Norwich, is now, I believe, consdered to be merely a common snipe, with the middle tailquills not grown to their full length.

Pied and other varieties are met with at times. A very beautiful specimen, resembling in appearance the buff-coloured woodcock described at p. 295, was shot at Guestwick in December, 1851. The ground colour in this bird was pure white; the usual markings being delicately traced in light and dark shades of buff,* with the beak and legs pink instead of green. Another curiously marked snipe, having the head and neck white, streaked and dotted with dark brown and yellowish markings, the remainder of the plumage of the usual tint, interspersed with white feathers, and the legs and beak yellowish white, was killed in this county in December, 1856. Again, in the autumn of 1866, as I am informed by $\mathrm{Mr}$. Anthony Hamond, jun., a pure white snipe was killed on Walton Common, when the Prince of Wales, with other sportsmen, was shooting over that part of the Westacre estate. This very interesting specimen is now preserved at Sandringham Hall. Messrs. Gurney and Fisher have also recorded a singular malformation of beak in this species, a snipe examined by them having had the beak "for

* M[r. J. H. Gurney, jun., has recorded in the "Zoologist" for 1868 (p. 1459), a somewhat similar variety in his own collection, which was purchased by Mr. Gatcombe, of Plymouth, in Leadenhall Market, about the 3rd of September. "It is fawn coloured, retaining, however, all the zigzag mottling of the normal plumage, but so faint as to be hardly discernible." 
considerably more than half its length, turned up like an avocet's."*

Snipes, like woodcocks, plovers, and other marsh birds, are not unfrequently found dead under the telegraph wires, having flown against them in their nocturnal flights; but some three or four years since a snipe was knocked down by the sails of a mill at Dilham, in this county, in a very remarkable manner. The bird rose from a field near a mill belonging to Mr. H. Ladell, of that place, in such a direction that, the machinery being in rapid motion at the time, it had one of its wings cut off by the sails, quite close to the body, as if severed with a knife. This occurrence happened on the 9th of May, and it is just possible that the bird at that time had a nest close by, and was in the habit of perching on the mill sails when stationary.

\section{SCOLOPAX GALLINULA, Linureus.}

\section{JACK SNIPE.}

The Jack or "half" Snipe, as a migrant only, visits us regularly in spring and autumn, frequenting the same localities as the "whole" snipe, but in its movements leading a perfectly independent existence. At times when the "whole" snipes are most plentiful, scarcely any jacks are to be met with; and occasionally, also, some favourite marsh may be found full of jacks, and hardly a "whole" snipe be seen in a day's shooting".

In autumn they usually make their appearance

* MIr. J. H. Gurney has since seen a similar specimen killed in Sussex, but with the beak not quite so much recurved. 
about the milllle or end of September, althongh stragglers have been occasionally observed at an earlier date. Mr. Lubbock states that on the 1st of August, 1833, he sirw a jack snipe, killed on Barton Fen. "The bird was in good plumage and condition," and he believed it had "migrated earlier than its wonted time." In 1831 he saw a couple that had been shot on the 12th of September, and he has seen others as early as the 8th. I have also notes of a comple seen by myself in 1852 , which had been shot at Barton on the 14th of September.* As with the common snipes, however, the jacks are most plentiful, and more generally dispersed during October and November; and though the larger number may take their departure during severe weather, yet even wore in proportion than the common snipes, resort during prolonged frosts to our inland spring's and water-courses, where, in certain sheltered nooks, they are always found in high condition. Whether less susceptible of cold, owing to their sluggish habits and rapid tendency to fatten, this species is certainly Iiardier than its more active kindred; for on more than one occision I have flushed several couples of jacks from the open marshes at Surlingham, when a frost, of two or three days" duration, had driven all the "whole" snipes from that neighbourhood. Upon this habit of taking the rough with the smooth, and still getting fit under trying circumstances, Mr. Lubbock aptly remarlis, "a driving wind, intermixed with sleet, often sets all the "whole" snipes upon a range of marsh in motion. They are perpetually changing place, and fly in small parties round and round, shrieking out

* In the "Zoologist" for 1868 (p. 1029), Mr. Cordeaux records a jack snipe as shot by himself in a turnip-field, in North Lincolnshire, on the 26th of September; and another correspondent (p. 1059), states that on the 24th of August, of the same year, he flushed a jack snipe in some water meadows, near Dorchester. 
their disgust at the storm. Not so the jack; the leeside of a tuft of grass, or a small piece of turf, affords him shelter, and there he ensconces himself with philosophic patience." When flushed the jack snipe emits no cry, but with a somewhat slow though tortuous flight mounts up gradually for a short distance, and then abruptly pitches down into any convenient shelter. The reluctance of the jack to take wing, whether on a marsh or by the sedgy margin of a river or drain, is well known, and the bird has acquired, from its apparent indifference to the sound of approaching footsteps or the report of firearms, the French name of Bécassine sourde; but as the hare, though conscious of danger, will, hoping to escape detection, crouch down in her form rather than trust to her swiftness of foot, so this species, I imagine, relies for safety in concealment, and rises only when compelled to do so. It is a very usual thing on the broads, when rowing round the edges of the reed-beds-looking for snipes on the mown "hoves," to get two or three shots at the "whole" suipes as they twist over the reeds, and then, on sending a dog on to the treacherous soil, to flush one or two jacks that would not otherwise have shown themselves. In like manner, when carefully looking a marsh for the second time in the day a staunch dog will usually find one or more jacks that had been passed over before; and even a bird that has been flushed and escaped to a distance, will not unfrequently be found in an hour or two in its former haunt. I remember on the 24th of October, 1859, during a somewhat early frost, finding five couples and a half of jack snipes in one corner of a marsh, which, judging from the "borings" all over the soil, was a most attractive spot. These birds rose one at a time, as the marshman and myself quartered the ground carefully, and those that I missed or had no chince of shooting at dropped again within twenty yards of 
us. Once as my attention was directed, whilst re-loading, to the numerous borings in the marsh, I saw a jack squatting down, in a little tuft of grass, within a yard or two of my feet, and in spite of my two barrels having just been diseharged,* it rose only when the man walked straight up to it. Another curious incident, which occurred at the same time, particularly marks the occasion in my mind. The marsh in question was bordered on one side by a wide drain, having a slightly raised bank, covered with coarse grass and sedges, and at a particular spot, close to the water's edge, I had marked down a jack and felt quite sure of finding it again. On walking up to the very tuft where I hat seen it alight, I stamped my foot, and instintly, to my utter astonishment, a magnificent cock pleissint rose from under the bank, and evidently by the noise he made was as much taken aback as myself at oni unlooked for meeting. I am not ashamed to own that I was nowhere with my first barrel, but the second landed the unlucky truant from some neighbouring coverts, safely on the opposite mirrsh. What became of that jack snipe I cammot say. In days of belief in sorcery and witeheraft I should probibly have decided that it changed into a cock pheasint on purpose to bother me. All I know is that I never saw it again.

By many authors, and even by so accurate an observer as Macgillivray, the jack snipe has been termed solitary, but although single birds may be found here and there, a careful search would, in all probability, discover one or more close by; at least such has invariably been my own experience. Unlike the "whole"

* I once flushed a "whole" snipe from under a wooden railway bridge, over which a heavy train had just passed, shaking the whole edifice; yet the snipe lay there undisturbed, until my footsteps alarmed it, when it started from under the bridge, and I dropped it on the "line" with a snap shot.

$2 \mathrm{x}$ 
snipes, jacks never rise in "wisps," but, as shown by the number I found myself, all gathered together within a very small space, they certainly congregate on the ground. As a further proof, also, of the independent action of this species, I could give many instances of their being found in numbers, almost exceeding the largest flights of the "whole" snipes; at times, also, when not a single bird of the larger species has been seen in the day. Yet, as a rule, perhaps Thompson's* estimate is not far wrong that jacks are " in the proportion of about one fourth of the common species." Mr. Lubbock states that "in October, 1824, in two days' shooting, thirty-seven snipes were killed by a friend, only five of which were "whole" snipes, and that later in the same month nineteen jack snipes were shot in one morning, and only one opportunity afforded of firing at a "whole" bird. When thus abundant it is evident that any one accustomed to the flight of a jack snipe will make a much larger bag than it would be possible to do with the larger species, which, rising several at a time and not waiting to be "walked up," have the chances much in their favour. About the year 1845, Mr. Rising, of Horsey, with a friend, killed in his own marshes thirty-five couples of jack snipes. His companion, however, did not arrive till about eleven o'clock, by which time Mr. Rising liad bagged ten couples and a shorteared owl, missing only one or two shots. Even more might have been killed had they continued shooting. On two or three other occasions he has met with similar extraordinary flights of jacks, and remembers when a very young sportsman, shooting away a pound of powder and cleaning his gum in the

* See Thompson's "Birds of Ireland" (vol. ii. p. 278) for the returus of a snipe-shooter's bag, in the nighbourhood of Belfast, from 1835 to 1812 inclusive. In the north of Ireland he considers that jack snipes have greatly increased of late years. 
course of the day, the bag amounting to fifteen comples of jacks, which, with good shooting, might have been doubled. In these instances, also, "whole" snipes were either very scarce or altogether absent.

In spring the jacks and "whole" snipes make their" appearance about the same time, and, as Mr. Lubbock remarks, "are often found in pairs for" a fortnight previous to their departure; and at that period they occasionally emit a feeble piping note when flushed." Notwithstanding, however, their late stay with us at times in the spring, particularly with a prevalence of north-easterly winds, and the fuct that stragglers have been met with during the summer months, there seems no reason to suppose that the jack snipe has ever bred in Norfolk, even though the late Mr. Stephen Miller, of Yarmouth, is stated by Messrs. Paget to have had jack snipes' egg's brought to him ; † and Yarrell in his paper on our British snipes in Loudon's "Magazine" (vol. ii., p. 11.k), says of the jack snipe in Norfolk, it "has been known (though very rarely) to breed in our marshes." It is by no means unusual to observe jack snipes hanging for sale in the Norwich Market, between the first and second week in April, and in cold backward seasons as late as the 24 th, $\ddagger$ or even into the following

* Mrr. J. H. Gurney informs me that on one occasion he looked over a large hamper of snipes from Cornwall, in Leadenhall Market, which, as far as he examined them, were all jacks.

+ Mrr. Lubbock, in his communication to Yarrell, remarks, "The eggs which have once or twice been oflered to me as those of the jack snipe were those of the purre, and I regret I can say nothing in favour of its breeding in Norfolk." The purre or dunlin, however, does not breed in Norfolk, though eggs may have been found dropped at random by those birds before quitting our shores.

¥ Mr. Harting informs me that on the 14th of April, 1868, he flushed trro jack snipes on a heath at West Harting, in Sussex, $2 \times 2$ 
month.* On the 29th of May, 1853, a single bird was shot at Hickling, but no more were seen. Mr. Lubbock with the late $\mathrm{Mr}$. Girdlestone found a pair of jack snipes on Bradwell Common, on the 1st of May, $1827 ; \dagger$ but a further search on the 8th proved fruitless. Both Mr. Lubbock and the Messis. Paget, also, refer to a reward of one sovereign, offered by $\mathrm{Mr}$. Girdlestone, to any one who could bring him a specimen of this bird shot in our marshes in summer. In July, 1825, a femman named Hewitt, brought him one which he had watched, from time to time, from the beginning of May, in a swamp near his house. On the 2nd of July he went to look for it in order to claim his reward, and found it in the old spot so sluggish and feeble that after a little trouble he succeeded in knocking it down with his hat. This bird, $\ddagger$ says Mr. Lubbock, to whom it was afterwards presenter by $\mathrm{Mr}$. Girdlestone, "was ragged in plumage, lean, and scurfy to a degree," and no doubt had, either from disease or some previous injury, been unable to migrate. Mr. Girdlestone is also said to have "killed one in high feather, on Belton Bog', July 21st, 1826," possibly a very early arrival from the

which he again put up and shot the following day. They proved to be only in a state of half change to their nesting plumage, and were both females.

* In the "Zoologist" for 1849 (p. 2456), Mr. P. E. Hansell, of Thorpe, near Norwich, states that on the 2nd of May, in the marshes between Thorpe and Postwick, he flushed a jack snipe, but " in a very weak state and could hardly fly." But no reliance can, of course, be placed on the assertion of the Norwich birdstuffer, who told Mr. Hansell that one or two nests had been taken here in that year.

+ This occurred in May, not June, as stated by Messrs. Paget. See Lubbock's "Fauna," p. 82, and his communication to Yarrell ("British Birds," vol. iii. p. 36).

‡ I have recently examined this bird in Mr. Newcome's collection, at Feltwell, to whom it was presented by Mr. Lubbock. 
north. Mr. A. Hamond, jun., informs me that he once found a jack snipe in a swampy part of East Walton Common, in June, but had no reason to suppose that the bird hat a nest there; and in June, 1868, a single bird of this species was seen by Riche, the broadman, at Surlingham; yet all such instances are no more evidence of this species intending to breed here* tham the presence on our const throughont the summer of a few dunlins, sanderlings, or grey plover.

The firct of the jack snipe during the breeding season emitting a strango noise when on the wing, yet differing altogether from the "drumming" of the common species, appears to have been first noticed by the late $\mathrm{Mr}$. Wolley. The following interesting description of it from the pen of that accomplished naturalist, is published by Hewitson ("Eggs of Brit. Bds.," 3rd ed.) :"It was on the 17th of June, 1853, in the great marsh of Muonioniska that I first heard the jack snipe, though at the time I could not at all guess what it was; an extraordinary sound unlike anything I had heard before. I could not tell from what direction it came, and it filled me with a curious surprise; my Fimish interpreter thought it was a capereally, and at that time I could not contradict him, but soon I found that it was a small bird gliding at a wild pace, at a great height over the marsh. I know not how better to describe the noise than by likening it to the cantering of a horse in the

* In Mr. A. G. More's paper "on the Distribution of Birds in Great Britain during the nesting season" I find the following observations ("Ibis," 1865, p. 438):- "A few instances are on record in which the jack snipe has been seen in England during the summer months; hitherto there appears to be no good authority for believing that the nest has been found in this island." In Lapland, Mr. A. Newton informs me the jack snipe seldom lays before the middle of June at the earliest, and constantly breeds quite into August. 
distance, over a hard hollow road; it came in fours with a similar cadence, and a like clear yet hollow sound. * * * It was not long after I heard it that I ascertained that the remarkable hammering noise in the air was made by the jack snipe." Some four of five nests of the jack snipe were found at this time by Mr. Wolley, at Karto Uoma, and identified by the capture of the parent birds, one of which allowed him to touch it with his hand before it rose. The nests were "alike in structure, made loosely of little pieces of grass and equisetum, not at all woven together, with a few old leaves of the dwarf birch, placed in a dry sedgy or grassy spot, close to a more open swamp."

The extraordinary disproportion in size between the eggrs of the jack snipe and the bird itself is even more surprising than in the case of the common species, since, to adopt Mr. Hewitson's description, "they are precisely of the same length as those of the snipe, but are of less width across the broadest part. The bird weighs about tivo ounces. The four eggs are more than an ounce and a half. The great egg' of the gruillemot is one eighth of the weight of the bird; the egg's of the jack snipe weigh nearly as much as it does itself." The eggs of this snipe are subject also to much variation in size and colouring. According to $\mathrm{Mr}$. Gould " there is but little external difference in the appearance of the sexes, one style of plumage being common to both;" but in the breeding season the colour of their plumage is intensified in the rich metallic tints of purple, green, and buff. Some of those killed here in autumn retain the rich purple colour on the upper tail coverts.*

* From a communication to the "Zoologist" for 1868, by $\mathbf{M r}$. E. H. Rodd, of Penzance (p. 1220), it would seem that the jack suipe moults all its tail feathers simultaneously in the spring. A specimen brought to him on the th of April had an entire new tail 
The stomachs of two shot by Mr. J. E. Harting, near Yarmouth, contained, in one, the remains of a crab and five or six small univilves, genus Turbo; the other, small beetles and grit.

\section{SCOLOPAX SABINII, Vigors.}

\section{SABINE'S SNIPE.}

Whether this singular bird is entitled or not to specific rank I must leave to abler ornithologists thin myself to decide, but although the opinion unquestionably gains ground that it is a variety only of the common snipe, I consider that with some future Selby or Yarrell must rest the responsibility of removing it from the "List" of British Birds. Under these circumstances the occurrence of a single example of the so-called Sabine's Suipe in Norfolk, enables me to introduce it for the first time amongst the more recent additions to the avi-fauna of this county.

On the 17th of October, 1856, a bird answering in every respect to the description of this snipe, as given by $\mathrm{Mr}_{\mathrm{r}}$. Vigors in the fourteenth volume of the Limnean Society's "Transactions" (as republished by Yarrell and others), was shot in a turnip field at Rainham, near Fakenham, by Mr. Martin Tupper Smith, and was afterwards preserved for the son of that gentleman, then an undergraduate of Trinity College, Cambridge, by $\mathrm{Mr}$. Baker, of that town. Mr. Osbert Salvin, who had the

"sprouting," which "had grown three-quarter's of an inch, the bases of the feathers being, of course, in a succulent state." If this late moulting be really a fact, and not an accidental occurrence, it may in some measure help to account for the late breeding. 
opportunity of examining this bird in the flesh,* in referring to my announcement of its occurrence in the "Zoologist" for 1857 (p. 5427) makes the following interesting remarks upon it in the same journal (p. 5593 ), his conclusions tending, however, with others to a belief in its being a variety of $S$. gallinago, and not a true species. Having mentioned the differences, though slight, observable both in the description and plates of this bird as given by Gould, Yarrell, Jardine and Selby, Macgillivray and Meyer, he observes: "The above differences are slight, it is true, but all tend to show that the plumage is not constant; and when we consider to how much variety $S$. gallinago is subject, especially the under surface of the wing, which presents every variety of marking from white to the other extreme, it requires no very wide gap in the chain of the series to suppose S. Sabinii to be the result of an excess of colour in the same way as the cream coloured varieties, which sometimes occur, may be said to be due to an absence of colour." The measurements of this bird, a female, as given by $\mathrm{Mr}$. Salvin, are as follows:- "Weight, four ounces; whole length, eleven and six-twelfths of an inch; length of wing from flexure, five inches; stretch of wings, sixteen and nine-twelfths of an inch; beak measured along the ridge, two and eleven-twelfths of an inch; along the edge of the under mandible, two and eighttwelfths of an inch; tarsus, one and five-twelfths of an inch; middle toe, one and three-twelfths of an inch; its claw, five-twenty-fourths of an inch; outer toe, one and one-twenty-fourth of an inch; its claw, two-twelfths of an inch; inner toe, twenty-one-twentyfourths of an inch; its claw, two-twelfths of an inch;

* A photograph of this Norfolk specimen, presented by Mr. A. Newton, will be found in the Committee-room of the Norwich Museum. 
hind toe, four-twelfths and its claw, three twenty-fourths of an inch; tibia bare for three lines above the tarsal joint; toes all separate; first and second primary quills the same length; number of tail feathers eleven; colour of legs olive green; iris dark hazel." Of the colour of the beak, he says, "I regret I can say nothing, for the bird having been liilled five days when I saw it, had faded apparently in this respect, as also the legs and iris, though the above colours, doubtless darker in the case of the legs than when alive, were quite distinct." Not having completed its autumn moult, the feathers of the tail and wings were imperfect; of the former, Mr. Salvin counted eleven, but was able to detect satisfactorily the absence of three, making the total number equal to those of the common snipe; and comparing also the sterna of $S$. sabinii and the common species, he says, "I am able to state that no specific difference, or rather no difference at all, exists; the length and breadth of the sternum, the curvature and depth of the keel, and the curvature of the furcula, all correspond exactly in each; in fact, it is impossible to distinguish them, and this is testimony in favour of the species being the same, of no small value, for $\mathrm{Mr}$. Alfred Newton, whose valuable collection of breastbones exhibits specimens of several species of Scolopax, assures me that a very marked difference subsists between the sterna of every member of the genus with which he is acquainted, and made special reference to those of $S$. gallinago and $S$. wilsoni species which, be it remembered, were for some time confounded; he also showed me the sterna of $S$. major and $S$. gallimula, which differed materially from each other, and from either of the above."

Not the least singular feature in the history of this bird, is the fact that hitherto it has not been met with ont of the British Islands, a circumstance equally re- 
markable whether the bird is regarded as a melanism of $S$. gallinago, or as a new and distinct species.

Several examples have now been recorded in various parts of England, and at least ten in Ireland, on the authority of Mr. Thompson, including the original one described by Mr. Vigors, which was shot in Queen's county, on the 21st of August, 1822; and one now in the Norwich Museum (No. 236), presented by $\mathrm{Mr}$. Alfied Newton, who procured it from the Museum of Trinity College, Dublin, which at that time possessed several other local specimens. An example recorded and minutely described by Mr. Hearle Rodd, of Penzance ("Zoologist," p. 7882), as having been killed near Carnauton, in Cornwall, in January, 1862, was examined, amongst other naturalists, by Mr. Gould, whose previous opinion as to its want of specific distinction was confirmed by the appearance of fourteen tailfeathers as in $S$. gallinago, and not twelve only as described by Mr. Vigors, which agrees with Mr. Salvin's account of the Norfolk bird; and two specimens mentioned by Thompson in his "Birds of Treland," had each thirteen tail-feathers, having evidently lost one. In this important point, therefore, the "black snipe" resembles $S$. gallinago. Another alleged difference between this bird and the common snipe, that it makes no cry on being flushed, seems equally unfounded, as Thompson states in his "Birds of Ireland" of two birds shot; one that rose with the common snipes did not 'squeak,' as the latter usually do when sprung, and that after being once fired at, it perched quite near again like a jack snipe. The other rose in company with a common snipe, and uttered a similar cry, but for which it would have escaped, as its colour led the sportsman at first sight to believe it to be a waterrail.

Mr. J. E. Harting, who has examined no less than 
five specimens of this snipe, gives the following reasons ("Birds of Middlesex") for considering it a distinct species, but has eridently overlooked the discovery in recent examples of more than twelve tail-feathers. "Firstly," he says, "in S. sabinii there is a total absence of white in the plumage, and none of the buff coloured markings on the head and back which appear in S. gallinago; secondly, the number of tail-feathers in $S$. sabinii is twelve, whereas $S$. gallinago has fourteen ; thirdly, the tarsus in $S$. sabinii is stouter and about an eight of an inch shorter than in S. gallinago; fourthly, in $S$. sabinii the eye is placed much higher in the head, as in $S$. rusticola; and lastly, if $S$. sabinii were only a variety of $S$. gallinago, however dark in colour the feathers might be, they would at all events be of the same shape. But it will be observed that in S. gallinago the feathers of the back are lanceolate in form, while in $S$. sabinii they are more ovate; in this respect more resembling S. rusticola." The latter is unquestionably the most important reason yet assigned for giving specific rank to this feathered paradox; but on the other hand, $\mathrm{Mr}$. Alfred Newton, in a recent commurication on this point, remarks-" I have seen, and more or less fully examined, no fewer than a dozen specimens of Sabine's snipe, and, on one occasion, I had the opportunity of comparing five together. I am strongly disposed to doubt its specific rank and to regard it as being only a melanoid variety of the common species. I have good reason for suspecting that all the examples I have seen were birds of the year, and if so, one fact to which $\mathrm{Mr}$. Harting in his 'Birds of Middlesex' has adverted, is satisfactorily explained, for I believe that in the common snipe the young of the year have the scapular feathers less pointed than the adult. I am, however, unable at present to speak positively on this subject, and the question must 2 Y 2 
therefore continue open." IMr. Cordeaux, also, who has of late been paying great attention to the parasites peculiar to different birds, informs me that after a most careful microscopic examination of a parasite taken from a recently lilled specimen* of Sabine's snipe, he could find no difference between it and the ordinary parasites found on the common snipe.

\section{MACRORHAMPHUS GRISEUS, Leach.}

\section{BROWN SNIPE.}

The Red-breasted, Brown, or Grey, Snipe, as this American species is variously termed from its seasonal changes of plumage, $\dagger$ has been procured in this county in at least three well authenticated instances. The first, killed at Yarmouth in the autumn of 1836, $t$ is described by Yarrell as in the collection of the Rev. Leonard Rudd, of Yorkshire, who forwarded the bird to London for his inspection. A second example is thus recorded by the late Mr. Hoy in the "Ammals of Natural History" for 1841 (vol. vi., p. 236). "We

* This bird, in the possession of Mr. J. H. Gurney, jun., was shot by Mr. C. Churchill, on the 7th of May, 1868, at Wareham, in Dorsetshire. On dissection Mr. Gurney found it to be a female, apparently a bird of the year, and a single parasite discoverer? amongst the feathers, was forwarded by him to Mr. Cordeaux for examination.

+ Red in summer, brown in autumn, and grey in winter.

* This specimen is also recorded in the "Annals of Natural History" for 1839 (vol. iii., p. 140), by Mr. Thomas Paine, jun., of Yarmouth, who states that it "was shot on Yarmouth beach, in October, 1836, and had not completely obtained its winter plumage when procured." He had been favoured with a sight of this bird by Mr. Leonard Rudd. 
learn from Mr. J. H. Gurney that a specimen of the red-breasted snipe was killed near Yarmouth early in October. Our informant adds that it was a male, and had nearly completed its change from summer to the winter plumage." This bird, which was formerly in Mr. S. Miller's collection at Yarmouth is now in Mr. J. H. Gurney's possession, together with another specimen said to have been killed at Runton, near Cromer, in 1840. A recent examination, however, of the latter with the testimony of the late Mr. John Sayer, of Norwich, who stuffed it, leaves no doubt on my mind that it was originally set up from a skin, and in that condition, and not in the "flesh," made its first appearance in Norfolk. In fact, there appears to be as little authority for this specimen as for the spotted sandpiper before referred to, which was said to have been killed at the same place and was sold to Mr. Gurney by the same individual. In $\mathrm{Mr}$. G. R. Gray's "Catalogue of British Birds" in the British Museum, two specimens are entered as forming part of that collection-Colonel Montagu's in winter plumage from Devonshire, and one purchased in 1850, marked "Norfolk, very young, from Mr. J. Baker's collection." In the absence of any record of this nestling in our natural history journals (although being in immature plumage it would, as a genuine British example, have been peculiarly interesting) I am inclined to doubt altogether the locality assigned to it. The Mr. Baker alluded to is, as I learn from Mr. Gray, "a dealer in such articles," and on such authority alone I cannot certainly include it as an authentic local specimen.

The last that I am aware of as killed in this county, which is now in Mr. Rising's collection at Horsey, was shot by himself, in his own marshes, on the 9 th of October, 1845, a male bird, changing from summer to winter plumage, and which was in company with another 
which he did not shoot at as it was raining hard at the time, and from a hurried glance at the one he had killed, he took it for nothing more than a young redshank.

This species is abundant in the United States of America, where it frequents the sea shore more than marshy ground, and is rarely seen inland. According to Yarrell, owing to the bill being "intermediate in its length between that of the true snipe's and sandpiper's, and some other peculiarities in which it also differs from both," it was placed in a separate genus by Dr. Leach under the term Macrorhamphus, which has been generally adopted. It is the red-breasted snipe of Wilson, and according to Audubon it is termed Bictssine de mer by the Creoles of Louisiana. Mr. Osbert Salvin, who found it a very common wader on the sand-banks of the Pacific coast of Guatemala,* remarks-"I used always to see it feeding in the open where there was no cover whatever, its habits strongly contrasting in this respect with the common snipe to which it is closely allied."

\section{TRINGA SUBARQUATA, Temminck.}

\section{CURLEW SANDPIPER.}

This species, known also as the Pigmy Curlew, is not unfiequently met with on our coast, both in spring and autumn, and more particularly in the latter season. From my own observations, more specimens seem to be obtained in September and October than at any other time. Messrs. Sheppard and Whitear, in their "Catalogue of Norfolk and Suffolk Birds," remark (1825)

* See "Ibis" for 1865, second series, p. 191. 
"several of these birds have been lilled at Yarmouth in the autumm. One of them which was shot at that place in the month of August, had a red breast, and was in plumage similar to the one in a summer dress preserved in the British Museum.* We have met with this species on Pewit Island. It is more solitary than the dunlin, not more than a pair being seen together; and is a stupid bird, suffering a boat to approach close to it. The legs of this bird, when fresh killed, are of a pale green, but when dried they appear black." As with most of our rare waders, more specimens have been procured on Breydon than on any other part of the coast, and the late Mr. J. D. Hoy has recorded in the "Magazine of Natural History" (new series, vol. i., p. 117), the occurrence of several specimens in summer plumage, near Yarmouth, in May, 1836. At Blakeney Mr. Dowell describes them as "not very rare, occurring for the most part singly amongst flocks of dunlins, and are easily distinguishable by their gait and longer bill and conspicuous white tail coverts." Examples in the rich red plumage of the breeding season are occasionally met with, either late in spring or on their return from their breeding grounds at the close of the summer. Mr. Gurney possesses a fine specimen in this plumage, killed on Breydon; and Yarrell, who was well acquainted with our Norfolk coast, says, "I have obtained this bird in June, in the height of its summer plumage, from Norfolli, and have seen the young from the same locality early in July." There is, of course, no reason to suppose that this species has ever remained to breed in this county, and the young birds above referred to must,

* A Norfolk specimen in winter plumage, presented by the Rev. W. Whitear, is preserved amongst the British birds in the British Museum, together with a Yarmouth specimen in summer dress presented by Mr. C. Hubbard. 
therefore, have commenced their southward passage thus early, in company with their parents, which supposition agrees with the statement of Messrs. Gurney and Fisher, that they arrive "about the end of July."

The specimen figured by Selby in his "British Ornithology," commencing the change to winter plumage, is stated by that author to have been lilled "on the Norfolk coast, in company with several others, which had nearly acquired the winter garb," and was presented to him by the late Mr. H. Girdlestone, of Yarmouth. This is one of the few instances in which they have been observed in any quantity at one time, but in the autumn of 1853, when an unusual number of specimens were procured on different parts of our coast, four out of five, as $\mathrm{Mr}$. Dowell informs me, were shot in Cley channel by Overton, the gumner, on the 7th of Sevtember, one of which was then in full summer plumage.

The following are a few instances of the occurrence of this species in Norfolk that have come under my notice during the last few years :-

1851. October 2nd. A pair killed at Yarmouth.

1853. March 19th. One near Haddiscoe. September 8th. One in full red plumage, and a young bird of the year, from Salthouse. October 1st. Three specimens from Yarmouth, besides the four before noticed as killed at Blakeney in September of that year.

1854. October 4th. A pair killed on Breydon, in company with one or two little stints. These are probably the same birds recorded by Mr. Southwell, in the "Naturalist," for January, 1855. A pair in Captain Longe's collection killed at Yarmouth about this date.

1861. October. One inland, near Swaffham.

1863. May. A handsome male, in full summer plumage, killed on Breydon, now in Mr. J. E. Harting's collection, together with another male, in a state of change, killed by himself on Breydon, on the last day of 
September. This bird, as stated by Mr. Harting, in the "Zoologist" (p.8827), was feeding alone, with the exception of a flock of gulls, on a mud flat, and allowed him to approach within forty yards before it rose. It uttered two sharp notes, not unlike a dunlin, but the wings looked longer, and the white tail coverts at once distinguished the species. The stomach contained the remains of small worms, coleopterous insects, and a few minute pebbles. September. One shot at Blakeney, in the collection of Mr. Beverley Leeds, of Lexham.

1865.* September 12th. One killed at Blakeney, in the collection of Mr. J. H. Gurney, jun.

1866. April 27th. A fine red bird, lilled on Breydon, by Mr. F. Harmer, in company with five grey plover and two dunlins, all of which were bagged at one shot with a punt gun. Two of the grey plover in nearly full summer plumage. This Mr. Harmer believes to have been the only bird of this species seen on Breydon during that season.

* Mr. Fenwick Hele, of Aldeburgh, who has during the last fer years procured sereral specimens of this sandpiper on that part of the Suffolk coast, has published the following notes on this species from time to time:-

"Field," 1865, September 16th. "Altogether about fifteen curlew sandpipers have been shot at Thorpe and elsewhere in this locality during the past and present months [August and September']. I have never met with them here before."

"Ficld," 1866, August 4th. "A good specimen of tho curlew sandpiper, in summer plumage, was brought me last week."

"Field," 1867, August 24th. "August 3rd. Two pigmy curlews, in summer plumage, were killed at Thorpe this morning."

"Field," 1867, May 25th. "On May 2nd, a most beautiful pigmy curlew," was lilled with several grey plovers and turnstones, in full summer plumage.

"Land and Water," 1867, October 25th. "Four killed within a few days." See also "Zoologist" for 1867, pp. 950 and 991. 


\section{TRINGA CANUTUS, Linnæus.}

\section{KNOT.}

This species is a regular and at times very numerous visitant to our coast, both in spring and autumn, and occasionally, if detained by a prevalence of northeasterly winds on its northward passage in May,* many beautirul specimens, in full summer plumage, are procured, in company with godwits, turnstones, greyplovers, and other migratory shore birds. This was particularly the case in the cold spring of 1853, which I have before noticed as a memorable season for our local collectors; and at that time, between the 10th and $\cdot 27$ th of May, an extraordinary number of red Knots from different parts of the coast were sent up to Norwich to be stuffed. On the 13th of May, as recorded by Mr. J. H. Guruey in the "Zoologist" (p. 3916), "a single gunner, at Yarmouth, procured seventy-three knots all in full, or nearly full, summer dress, besides several others which were obtained by other individuals." On the 14th, nine were killed out of a flock of about a dozen, by a crow-keeper, on what was formerly Salthouse Broad, but then sown with wheat; and these, which I examined at the time, were almost all in their perfect nuptial dress. Between the 14 th and 19 th, seventeen were received by one of our Norwich birdstuffers from Blakeney, and more inland localities in the "Broad" district, such as Hickling, Rockland, and Sutton; these birds, though essentially shore feeders, occasionally frequenting the land at some distance from the coast. Mr. Hunt speals of them as sometimes met with "far inland;" and $\mathrm{Mr}$.

* The specimen from which the figure in Yarrell's "British Birds" was taken, was procured at Yarmouth on tho 20th of May, 1820. 
Neweome has one in winter plumage, killed in Hockwolt Fen. In the cold backward spring of 1864, they were also plentiful at Yarmouth, but singularly enough in May, 1866, when the bar-tailed godwits, in fine summer plumage, were so numerous on Breydon, searcely any knots were seen. In 1857, Mr. Dowell saw three at Blakeney, in company with dunlins, on the 27 th of A pril, which still retained their full winter dress. A few stragglers of this species, as of sanderlings and other shore birds that never breed in Norfolk, may be met with occasionally throughout the summer months, as I have known specimens procured both in June and July; and in the second week of June, 1863, I saw one at Hunstanton, with a small flock of dunlins.

Inspite of the high northern latitudes to which these birds betake themselves for breeding purposes, and their late stay on our shores, the return passage is commenced very early in autumn. By the 9th of August Mr. Dowell has observed both young and old in Blakeney harbour, and I lave known the young birds of the year killed at Yarmouth on the 16th; the time of their arrival, however, varies much in different seasons. From MIr. Dowell's notes, I find that in 1846 they began to arrive at Blakeney about the 20th of September, but in 1847 scarcely a bird had been seen before the 5th of November. On the 9 th of September, 1848, he shot twenty-eight, and might have lilled many more, as they made their appearance in small flocks of from five to twenty, and were very tame. In 1850 very few were seen in the harbour at Blakeney until the first week of December, "when flocks of many thousands appeared on the west sands." Again in August, 1853, towards the end of the month, they were very numerous in lots of from fire to a hundred. The first flights are described by Mr. Dowell as by no means difficult of approach, "but as the season 2 z 2 
advunces and more arrive, they assemble in larger flocks, and are then much more wary, and except in dirty weather are not to be approached but by aid of a gunning punt. Those which arrive in August and September usually leave again in October, and very large flocks are but rarely seen before the end of November." Overton, the Blakeney gumner, once shot two hundred and thirty lnots, twenty-five grey plovers, and eighteen redshanks.

On Breydon these birds are seldom met with late in the autumn, after the usual migratory flocks have passed on, but Mr. J. E. Harting, who spent some days at Yarmouth, in October, 1867, informs me that on the 26th he shot a solitary knot on the muds, which he had observed in company with a few dunlins a day or two before; and this appeared to be the only one then remaining in that neighbourhood. ' In winter their plenty or scarcity appears to depend much upon the season, as I find by my own notes that during severe frost and snow many are sent up to the Norwich market from Yarmouth, Blakeney, and the shores of the Wash. This was particularly the case during the very severe weather which prevailed in February, 1853; January, 1862 ; and January, 1867.

The Rev. C. A. Johns, who has had opportunities of observing the species in this county, remarks ("British Birds in their Haunts"), "Some author's state that it feeds principally early and late in the day, and during moonlight nights; but I have seen it on the coast of Norfolk, in winter, feeding at all hours of the day in company with dunlins, sanderlings, and purplesandpipers, and differing little from these in the mode of obtaining its food. But I remarked on several occasions that when a flock was disturbed the knots often remained behind, being less fearful of the presence of man; in consequence of which tardiness in rising 
they more than once fell to our guns after their companions had flown off. On their first arrival they are said to be so indifferent to the vicinity of human beings, that it is not difficult to knock them down with stones. Their provincial name in Norfolk is the green-legged shank; the latter name "shank" being applied for shortness to the red shank."* In proof, also, of their unsuspicious nature, Messis. Sheppard and Whitear make the following statement:- "We met with a flock of sixteen in September last [182.1] which, though repeatedly shot at, would not leave the spot, and were all killed. Some of them being wounded fell into the water, and swam about with great ease."

These birds are considered extremely good eating; and in former days appear to have been systematically fattened for the table like quails and ortolans. Sir Thomas Browne describes them as "taken with nets" when "they grow excessively fat, being mewed $\uparrow$ and fed with corn. A candle lighted in the room, they feed day and night, and when they are at their height of fatness, they begin to grow lame, and are then killed as at their prime and apt to decline."

In the L'Estrange "Household Book" knots are twice mentioned with other waders-" Itm pd to hym for a curlewe, a dosyn knotts, a dosyn redschanks and stynts, ij teals - ijs. -." "Itm pd to the fowler for ijj dosyn and di [half] of lnotts, - iijs. - jd. - ;" and are thus noticed in the Northumberland "Household

* For a good account of the habits of knots, dunlins, and greyplovers when feeding, see a paper by Mr. J. Cordeaux, in the "Zoulogist" for 1866 (p. 216).

†'To "merv," properly signifying to moult, was in hawking days used in another sense as in this jassage, and signified to confine. The places where hawks were kept when shedding their feathers were called "mews," and hence the term applied to tho livery stables in London at the present time. 
Book"- "Itm knottes for my Lorde at Principall Feestes and no other tyme, and at a jd. a pece, except my Lordes commandment be otherwise."

The stomach of a specimen killed by Mr. Dowell, at Blakeney, in the month of December, contained from one hundred to one hundred and fifty small shells, and in two examples killed in May, and examined by Mr. Harting, were found, in one, three shells of the common periwinkle; and in the other one hundred and fifty small bivalve shells belonging to the genera Rissoa and Turbo.

\section{TRINGA RUFESCENS, Vieillot.}

\section{BUFF-BREASTED SANDPIPER.}

This rare straggler from the American continent was first included in the list of British birds by the late Mr. Yarrell, who, in the sixteenth volume of the the "Limmean Transactions," described "a species of Tringa, killed in Cambridgeshire, new to England and Europe."* The same author also, in some further remarks on this specimen, in lis history of "British Birds," says- "This bird was shot early in the month of September, 1826, in the parish of Melbourne, in Cambridgeshire, in company with some dotterel (Charadrius morinellus), and passed immediately afterwards into the possession of Mr. Baker, of Melbourne, by whom the skin was preserved, and of whom it was purchased by John Sims for me. A few years afterwards Mr. John Sims, who had then removed to Norwich, obtained a second example of this species,

* See also Eyton's " History of the rarer British Birds" (p. 39), with a figure of this bird. 
which was killed at Sherringham, on the coast of Norfolk, and which he preserved for the Norwich Mruseum." Amongst the British birds in that institution (No. 2.10) this local rarity, although in rather a dilapidated condition, is still preserved, and according to an entry in the donation book of that date, it was killed at Sherringham, July 29th, 1832, and was presented by Mr. Arthur Upcher. Since that time three other specimens, as recorded by Yarrell, have occurred in this county, but not of late years. One at Yarmouth in the autumn of 1839 or 1840 , which came into the possession of the late Mr. Heysham, of Carlisle; another in the same locality on the 22nd of September, 1811; and another on the mud-flats of Breydon, September 20th, 1843. Of the latter, Mr. W. R. Fisher writes in the "Zoologist" for 1813 (p. 363), "the bird had been observed for two or three days on the same piece of mud, in company with a ruff and a greenshank, the latter of which birds was killed at the same time with it. The sex was unnoticed." Both this and the preceding bird are now in Mr. J. H. Gurney's collection.*

\section{TRINGA PLATYRHYNCHA, Temminck.}

\section{BROAD-BILLED SANDPIPER.}

As stated by Yarrell, the first British killed specimen of this straggler from the north of Europe was

* The breeding grounds of this species have lately been found in Aretic America by the collectors employed by the Smithsonian Institution, and its egg has been figured in the "Proceedings" of the Zoological Society for 1867 (pl. xv., fig. 4). It would seem to be more nearly allied to the fresh-water or inland saudpipers (Tutunus) than to those of the shore (Tringa), and a new genus Tryngitis has been instituted for its reception. 
procured in Norfolk, and the particulars of its occurrence were thus described by the late Mr. J. D. Hoy, in the "Magazine of Natural History" for 1837 (new series, vol. i., p. 116):-_" It was shot on the 25th of May, 1836, on the muddy flats of Breydon Broad. It was in company with some dunlins and ring-plovers. From the season of the year it had probably acquired its summer plumage, and it very closely agrees with the nuptial garb of the species as given by Temminck. This bird is rather inferior in size to the dunlin, but may be always readily distinguished from that species by the peculiar form of the bill, as well as by considerable difference in plumage. This specimen was preserved by a friend of mine, ${ }^{*}$ who did not notice the sex. It is probable that this sandpiper may occasionally be found on our eastern coasts during the time of its periodical flights, but, from its similarity to one or two closely allied species, has hitherto escaped detection." This supposition has been fully borne out, insomuch as two other examples have been since killed on Breydon, and both having been picked out from amongst a number of dunlins and ringed-plovers shot at the same time; it is more than probable that others may have been passed over unnoticed. Of the two latter specimens, the first, in Mr. J. H. Gurney's collection, was killed on Breydon, May 25th, 1856, and proved to be a male, in breeding plumage, as recorded by $\mathrm{Mr}$. Gurney in the "Zoologist" (p. 5159). The second, in my own possession, from which Mr. Gould has made a drawing for his "Birds of Great Britain," I purchased, in the flesh, on

* In Dr. Bree's description of Mr. Hoy's collection of birds, at Stoke Nayland, published in the "Field" of 1867 (rol. xxx., p. 4.66), it is particularly stated that there is no evidence of this specimen ever having been in Mr. Hoy's possession, nor can I ascertain what has become of it. 


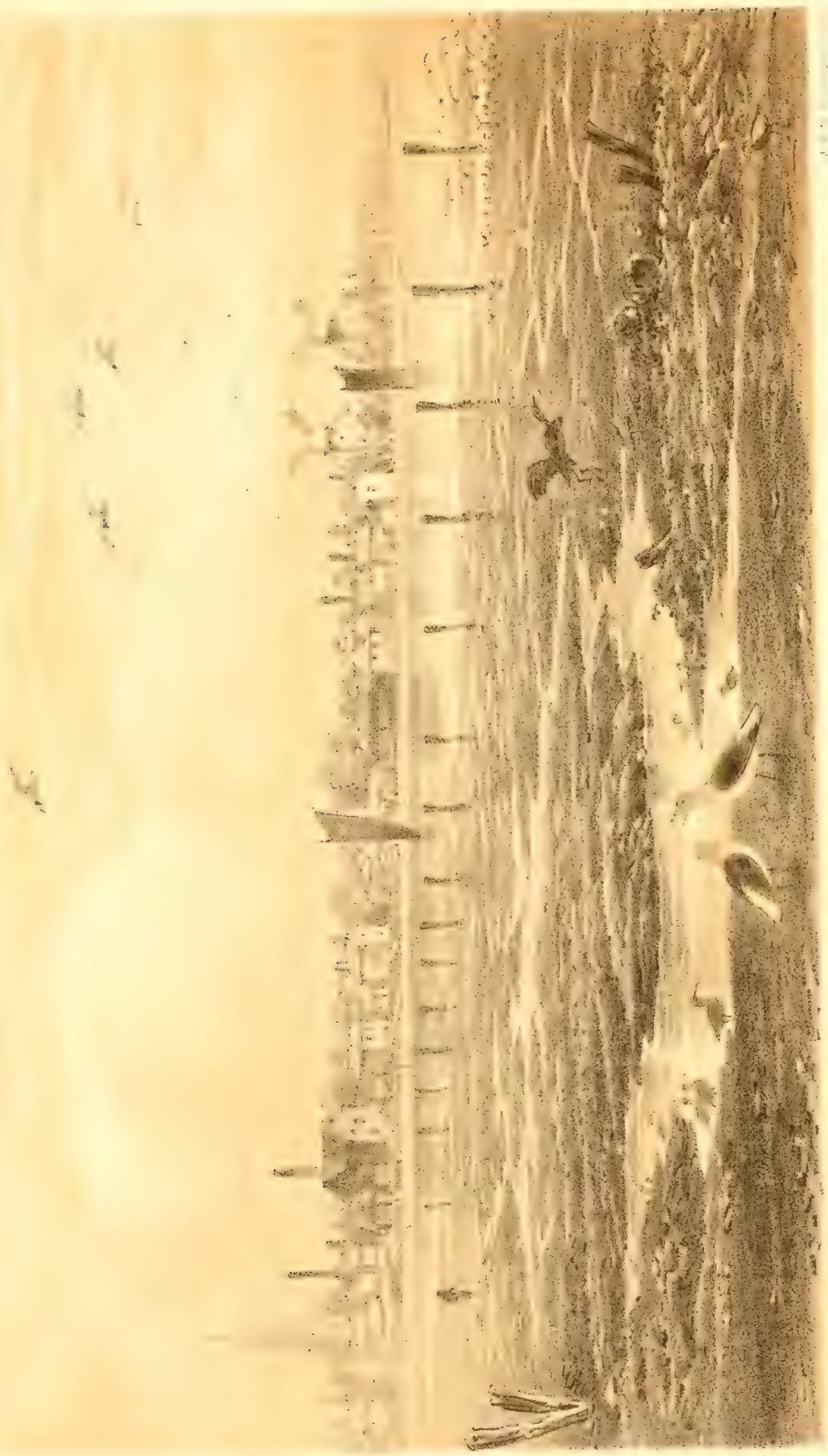



the 2:3rd of April, 1863. This bird was also killed on Breydon, a male, gradually assuming its summer plumage, the rufous edgings of the feathers appearing orer the head, back, and scapulars. This is the last to my linowledge that has been observed in this county, and it is noticeable that all hare appeared on their passage northward in spring.

Among the "British Birds" in the Norwich Museum sill be found two or three interesting specimens of this sandpiper, procured by the late Mr. Wolley in Lapland, during the height of the breeding season, and his description of its egrgs and breeding habits will be found in the third elition of Hervitson's "Eggs of British Birds."

\section{TRINGA HINUTA, Leisler.}

\section{LTTTLE STINT.}

This elegant little sandpiper, though appearing only in small flocks, is a regular autumnal visitant to our coast, and, as shown by my notes for the last twenty years, is most firequently met with in the months of August, September, and October. In spring it is occasionally seen on its northward passage in May, and at times as late as the second and third week of June in the rich colour of its nuptial dress. I have a note of one lilled at Yarmouth, on the 21st of May, 1853; and in Ciptain Longe's collection are two or three specimens obtained on Breydon about the 18th of June; others have also been seen by him quite as late in the season. A single specimen was shot at Wootton, near Lymn, on the 19th of June, 1865; and a very beautiful example in my own collection, in full summer plumage, was shot at Salthouse, on the 18th of June, 1868, from a flock of four or five which had frequented the beach there for some days. With the exception only 3 A 
of Breydon mud-flats, the margins of the brackish water, which at Salthouse divide the shingle from the sea-banks and marshes, are the most farourite resort of this diminutive species, and from whence at different times I have received several. Others have been procured also from the beach at Cromer, Sherringham, and Hunstanton, as well as from the shores of the Blakeney chamnel, where, according to $\mathrm{Mr}$. Dowell, they are somewhat rare visitants. Messis. Gurney and Fisher have recorded in the "Zoologist" for 1818 (p. 2292), the occurrence, on the 13th of September, of a flock of seven on Yarmouth beach, and the following have come under my notice during the last few years:-

1863. Angust 12th. Two in Mr. H. Upcher's collection from Sherringham beach. September 26th. One sent me from Salthouse still retaining a portion of its summer dress. Several others seen at the sime time.

1865. August 5th. Three sent me from Salthouse in nearly full summer plumage.

1866. October 19th. One killed on the beach at Hunstanton.

1868. May 20th. A male, in full summer plumage, sent me from Yarmouth; and on the 18th of June two more from Salthouse where others had been seen.

September. Mr. J. H. Gurney, jun., received one from Cromer.

1869. July 16th. A fine specimen killed at Yarmouth. Two others shot a week or two before were, unfortunately, not preserved.

Mr. J. H. Gurney informs me that on one occasion when shooting at Salthouse, a little stint having been only slightly wounded in the wing, he carried it alive to Cromer, and turned it loose in his room, where, to his surprise, it exhibited so little uneasiness in its new quarters that on the same day it ate flies out of his hand without the least symptom of alarm. 


\section{TRINGA TEMMINCKI, Leisler.}

\section{TEMMINCK'S STINT.}

Since the distinguishing characteristies of this minute Tringa have been better understood, specimens lave been identified in Norfolk in very many instances. This species was not included by Messis. Sheppard and Whitear in their Catalogue in 1825, nor by Mr. IIunt in his "List" published in 1829; but in Selby"s "British Ornithology" "a male and female, killed in Norfolk in May, 1830," are stated to be in his possession; and in the "Magazine of Natural History" for $18: 37$ (new series, vol. i., p. 117), Mr. J. D. Hoy has recorded two specimens, birds of the year, as killed near Yarmouth, in September, 18:35, and an adult bird, on Breydon, in the following May. Messrs. Paget (1834), speaking of the little stint as "not uncommon about Breydon," remark "probably the Tringa temmincki occurs too;" and in $18 \pm 6$ it was described by Messr's. Gurney and Fisher as appearing "occasionally" but "less regularly and much less numeronsly." A specimen in the late Mr. S. Miller's collection, was probably procured at Yarmouth some years ago.*

As this stint is, I think, grenerally considered more rare than it really is, I subjoin all the instances in which, to my linowledge, it lias occurred in Norfoll of lite years; whilst others have, no doubt, passed unnoticed, or at least unrecorded, during that period.

1843. Mr. W. R. Fisher, then living at Yarmouth, as stated by Morris in his "British Birds," knew of four shot there in September: and October of this year, and

* In Mr. Spalding's collection at Westleton, is a 'Temminck's stint, shot by himself out of a flock of ten, on Benacre Broad, Suffolk, about trenty years ago.

3 A 2 
had in his possession two other Yarmouth specimensone killed in May and the other in September.

1847. May 14th. One killed at Yarmouth, as noticed by Messrs. Gurney and Fisher in the "Zoologist" (p. 1785).*

1850. August 20th. One adult and one immature specimen, in the "Dennis collection," at Bury, were killed at Yarmouth.

1851. October 2nd. One from Yarmouth.

1853. May 16th. Two in a state of half change from winter to summer plumage. One of these is in MIr. J. H. Gurney's and the other in my own collection. I have also another Yarmouth specimen killed somewhere about this date.

1861. May 23rd. One at Yarmouth, also prurchased by Mr. Gurney, which, from its late appearance, had nearly completed its breeding plumage. Another was shot about the same time on Breydon by Captain Longe, who has it preserved in his collection at Yarmouth.

November 23rd. A third example in this year was also killed on Breydon, and is in the possession of the Rev. C. J. Lucas, of Burgh.

1862. Captain Longe informs me that he saw three or four specimens during May and June, killed in the marshes around Breydon; and one in his own possession was shot on the 19th of August, on Breydon muds. The Rev. C. J. Lucas has also one killed on Breydon, in this year, on the 16th of May, far advanced in summer plumage.

1866.† May. A specimen killed at Yarmouth during

* In the "Zoologist" for 1819 (p. 2623), Mr. F. W. Foster, of the Wisbech Museum, records a Temminck's stint as "shot on the banks of the river, less than a mile below the town," which he preserved for the museum. A pigmy curlerv and little stint wero killed at the same time.

$\dagger$ Mr. Hele, of Aldeburgh, on the Suffolk coast, has recorded in 
this montl, is in Mr. J. Tomlinson's collection. September 12th, two specimens were shot near Lymm, by Mr. G. Cresswell, as recorded by Dr. Lowe in the "Zoologist" for that year (p. 457). Both were females, and much injured by the shot, but one was preserved for the Lynn Museum.

Amongst the "British Birds" in the Norwich Iruseum will be found a nestling of this minute sandpiper (No. 24tc), with adult specimens* in full summer plumage, collected by the late Mr. Wolley, from localities north of the Bothnian gulf, together with the egrgs, till then hardly known. The following most graphie account from Mr. Wolley's own pen, of the habits of this species in its breeding haunts, is quoted from Hervitson's third edition of the "Egrgs of British Birds" — "Grassy banks and pastures by the waterside are the kind of places where it takes up its breeding quarters, and it seems to delight to be near houses. Nothing can be more interesting or pretty than this little bird in the early part of summer; it is so tame that one could often catch it in a net at the end of a stick. At one time it is hovering with its wings raised over its back, or floating about, and it reminds one rather of some insect than any other bird ; at another time it may be standing on the top of a stone or stake, or the gable end of a cottage, and, whether hovering or standing on its perch, it utters a constant trilling note, of which I can best give an idea by saying that it brought to my recollec-

the "Field" during the last three or four years, the following occurrences of this species. In 1865, about the end of August, two at Thorpe Mere. In 1866, in September, specimens of both Temminck's and the little stint were killed near Aldeburgh. May 2nd, 1867, one at Thorpe MFere.

* No. 244a, "male, Karesuando, June 20th, 1854. No. 244b [sex not noted] "Alcola, July 21st, 1853." No. 241c [as above mentioned] " from nest, Alcola, July 21st, 1853." 
tion the grasshopper warbler, though the resemblance is perhaps slight."

Mr. Harting has so accurately described in his "Birds of Middlesex,"* the chief points of difference both in habits and plumage, between 'Temminck's and the little stint, that I camnot do better than quote his remarks, to assist young collectors in distinguishing these two species. "Temmincli's Stint may be regarded as a miniature common sandpiper, exhibiting a more miform colour throughout, and having light coloured legs, while the little stint, like a miniature dunlin, displays a more mottled and varied plumage, and has black legs. Nor need the parallel, I think, be confined to the plumage only, for as far as my experience goes, Temminck's stint, like the common sandpiper, affects the soft mud around inland pools and marshes, while the little stint, like the dunlin, prefers the sand and shingle of the sea-shore." This opinion is certainly borne out by the character of the respective localities most frequented by these two species on our Norfolk coast, but the muds of Breydon, with its tidal waters, form a common resort for these and all other kinds of Tringa.

The American Little Stint, the Tringa pusilla of Wilson,-included by Yarrell in the preface to the third edition of his "British Birds," from an example shot by Mr. W. H. Vingoe, on the 10th of October, 1853 (see "Zoologist," 1854, p. 4.297), in Marazion marsh, near Penzance,-has not hitherto been observed in Norfollk.

* See also a valuable paper by the same author on "the distinguishing characters of some nearly allied species of British birds," in the "Zoologist" for 1867 (p. 973.) 


\section{TRINGA PECTORALIS, Bonaparte.}

PECTORAL SANDPIPER.

The first British killed specimen of this rare Tringa, as was the case also with the broad-billed sandpiper, was procured on Breydon, and its occurrence is thus recorded by the late Mr. J. D. Hoy in the "Magazine of Natural History" for 1837 (new series, vol, i., p. 116) :-_6 It was killed on October 17th, 18:30, on the borders of Breydon Broad, an extensive sheet of water, near Yarmouth, rather celebrated for the numerous rare birds which have, at different times, been observed and shot on its banks and waters. The person who killed it remarked that it was solitary, and its note was new to him, which induced him to shoot it. It proved to be a female on dissection. It was preserved by the late Mr. J. Harvey, of Yarmouth, as a curious variety of $T$. variabilis, with some doubts as to whether it might not be a new species. I detected the bird in Harvey's collection, and felt convinced it was an undescribed species of Tringu." In corroboration of the above, it is stated by Yarrell that Mr. Hoy having obtained possession of this bird,* sent it up to him, in London, for inspection, where Audubon, then staying in England, had an opportunity of examining it, and "he immediately confirmed the previous notion that the bird was an example of the Tringa pectoratis of America."

In the "Zoologist" for 1849 (p. 2392) Mr. J. H.

* Dr. Bree mentions this specimen in his description of $\mathrm{Mr}$. Hoy's collection of Birds, at Stoke Nayland, in the "Field" for 1867 (vol. xxx., p. 466):- "I regret to say it is not in the collection. I understand, however, that Mr. Hoy's surviving brother has some of the birds, and probably this may be among them." Possibly the first Norfolk killed broad-billed sandpiper may also be in the same hands. 
Gurney recorded a second example as killed on the Denes at Yarmouth, in the last week of September, 18-18; but in a subsequent note in the same journal (1. 2568), he adds, "I now much regret to say that I fear that I was imposed upon with respect to this specimen, and that it is in reality a foreign one." Subsequent enquiry has confirmed this impression, but the bird in question will be found in the British series (No. 246) at the Norwich Museum.

On the 30th of September, 1853, however, a specimen, now in Mr. J. H. Gurney's possession, was obtained near Yarmouth, and was thus recorded by him in the "Zoologist" (p. 412-1):- "I had the opportunity of examining this sandpiper in the flesh; it was a female, and apparently a bird of the year; it was not fat but in very filir condition. The stomach contained some small seeds and the remains of a few insects, but too mutilated to be recognisable with clearness." Since that date, two more authentic specimens have been also procured in Norfolk. The first of these, in my own collection, was lilled at Caister, near Yarmouth, on the 16th of September, 1865, and was brought to me in the flesh; unfortunately a shot had rendered the sex undistinguishable by dissection. The second, and last to my knowledge observed on our coast, was netted by a man named Hornigold, in Terrington marsh, near Lynn, on the 9th of January, 1868. This bird, which was preserved for the Lymn Musemm by Mr. Wilson, of that town, proved to be a female, and, judging from the plumage, a young bird of the previous year. Through the kindness of Dr. Lowe, I had the pleasure of examining this bird soon after it was mounted, and of comparing it with my own and Mr. Gurney's specimen.

Unfortunately Mr. Hoy's brief accomit of the bird which he purchased from Harvey, of Yarmouth, affords 
in means of julging wheiher it was in an immature or adult state, but I have lately had the opportunity of comparing ny own and Mr. Gurney's* eximples with a series of foreign skins in $\mathrm{Mr}$. Gould's collection, from which it is easy to trace the gradual changes of plumage in this species from the less conspienons markings of the young birl in its first autumn to the more defined and richer tints of the adult during the breeding sesson. Mr. Gurney's bird, as suggested by him, is 110 doubt in the plumnge of its first autumm, and so nearly agrees with the deseription given by Yarrell from a specimon sent lim by Andubon, that I need only add that its general dimensions are larger than in mine, even though the plumage of the latter indicates a fir more advanced age. The most striking feature, however, in the plumage of my own specimen consists in the marking's on the breast crossing the tips of the feather's in an arrow-head form, reminding one somewhat of Bartram's sandpiper, while in Mr. Gurney's the breast feathers are streaked with dark brown in the line of the shaft of each fuather. The rest of the plumage in my own, no duubt a fully alult biri, indicates a rapid state of change between sumner and winter plumage, and, from the appearance of the breast, where the arrowhead markings are very irregularly distributed, one might almost infer that these are peculiar to the nuptial dress. The rufous margins to the feathers on the head and back are in mine broader and richer in colour than in Mr. Gurney's, which are light wood brown; those on the head are more dark brown than chestnut.

The following table gives the comparative measurements of these two Norfolk killed examiles as taken from the stuffed specimens, both of which were set up

* It is, I believe, Mrr. Gould's intention to figure both these specimens in his "Birds of Great Britain."

3 B 
from the flesh. Number one represents Mr. Gurney's bird ; number two my own :-

$$
\text { No. } 1 .
$$

No. 2.

Tip of bill to end of
longest tail feather 8 inches and 6-8ths ... 7 inches and 7-8ths Wing, carpal joint to $\left.\begin{array}{l}\text { end of longest pri- } \\ \text { mary .................. }\end{array}\right\} 5$ inches and 1-8th ... 5 inches* Bill....................... 1 inch and 1-16th ... 1 inch Tibia, full length ..... 1 inch and 2-8ths ... 1 inch and 2-8ths Tarsus .................. 1 inch and 1-10th ... 1 inch Middle toe and claw ... 1 inch $\quad . .1$ inch and 1-16th

The Lynn bird, like Mr. Gumey's, a female, has the markings on the breast following the shaft of each feather, and is evidently immature, but has a single new feather with rufous edges in the tail, marking the commencement of a spring change, so early even as the 9th of January. On the back and shoulders the centre of each feather is blackish brown, edged somewhat broadly with grey, some few having a reddish tinge, but none rufous. Greater-wing coverts slightly red at the edges, and more markedly so the feathers on the head and back of the neck. The measurements of this bird, taken after it was mounted, agree with those of my own rather than Mr. Gurney's, and are identical with those of an immature foreign specimen, in the same state of plumage (No. 246a), in the Norwich Museum. Individuals, therefore, of both sexes, no doubt, vary much in size as is the case so remarkably with the dunlins and some other waders. $\dagger$

* Proportionate length of quills the same in each specimen.

+ As Mr. Newton informs me the dimensions of the two specimens given in the above table "are considerably less than those of six given by Cassin in Professor Baird's 'Birds of North America' (p. 721); the largest of these measures 9.32 in. in entire length, and $5.75 \mathrm{in}$. in that of the wing; while the smallest, the entire length of which is $8.6 \mathrm{tin.}$, or somewhat less than Mr. 


\section{TRINGA VARIABILIS, Meyer and Wolf.}

\section{DUNLIN.}

With the exception of a very short period, during the height of the breeding season, the Dunlin, Purre,* or Stint (as it is commonly termed in Norfolk), is found on our coast in more or less abundance throughout the year. As early sometimes as the first week in July, young and old together, in family groups, may be met with on our shores, in localities also where, later in the season, they are but rarely seen; and these, after roving awhile over the weed-covered rocks and shingle, join the later migratory flocks in their more accustomed haunts, such as the mud-flats of Breydon, and the ouzy margins of our tidal channels at Blakeney and Lynn. Indeed, the entire coast line to the north and west, from Cley harbour to the further shores of the Wash, backed by a wide range of saltmarshes, affords both at high and low water the most favourable conditions for this abundant species. From Mr. Dowell's notes I find that in 1848 many flocks had arrived about Blakeney

Gurney's bird, has a wing of $5.16 \mathrm{in}$. This species, the oldest name of which seems to be Tringa maculata, Vieillot, is of frequent occurrence in most parts of America, and is commonly known in the United States as the 'Jack-snipe."

* This term, as used by Penuant and other early authors, referred to this species in its winter garb, the name of dunlin being applied to the same bird in its summer dress until these seasonal changes of plumage became better understood. Again, Sir Thomas Browne, speaking of the abundance of stints upon "the shore and marshes about Stiffkey, Burnham, and other parts," says there is "Another small bird, somewhat larger than a stint, called a churr, and is commonly taken among them." Churr is here, no doubt, used for purre, and the bird mentioned, was probably a full-sized dunlin in one of its various stages of plumage. 
harboul, by the 2eth of July, in full summer plunage, which by the beginning of September had mostly completed their winter dress. In 1851, by the soth of July, they hat returned in flocks of from fire to fifty, and neyain in 185:3, on the 1st of July, \% he observed more thin one humdred together on the shingle bank, the old birds being in full summer plumage. A large portion, however, of our antummal visitants shift their cuarters again Iater in tho season, under certain conditions of wind and temperature, and not unfrequently during September and October scarcely more than one or two small flocks will be seen, where so recently the mingling footstens of a fenthered lost might be traced on crery part of the muddy estuary.

Yet, neither in spring nor autumn en their numbers be compared to the thousinds which pour in upon us occasionally in severe winters. At such times I have seen them on Breydon in countless numbers, crowding the water's edge at the first turn of the tide, and never quitting the mud-flats till the retuming waters farly washed them off their feet, from the highest ground in the harbour. With a knowledge of this habit, certain portions of the "muds" lave been artificially raised at various times, and on these not only the dinlins and other waders, but many kinds of fowl frozen out from the broads and rivers, collect in order to feed on the small

* Mr. Cordeaux in his "Notes on the Ornithology of Spurn Point" on the Yorkshire coast, published in the "Zoologist" for 1868 (p. 1317), describes the dunlin as numerous on the 2 nd of July, flying in flocks along the beach, and estimated one flock at about three hundred birds. Thompson, in his "Birds of Ireland," states that he noted their arrival in Belfast Bay as early as the 30th of June, 1812, when about a dozen appeared. In 1838 and 1840 large flocks arrived by the 3rd and 5th of July, but in some years they were not seen before the end of that month. Flocks of from two thousand to five thousand have been seen in mid-winter. 
Cinstacea, Mollusea and other marine animals, periodically exposed by the tide. Thus crowded together, the birts present a fatal mark for the big swivel gims, and an almost ineredible number are sometimes lilled at a single discharge. Messis. Gurney and Fisher, in the concluding observations to their "Accont of the Birds found in Norfolk," stite that upwards of eight humdacd dunlins were brought to a dealer in Tamnouth on the 11th of December, 18\%1; and on the 16th of the sime month some two hundred more, besides large numbers of other water-birks. I have also known, much more recently, as many as two hundred dunlins obtained in the diay by one individual. Should the frost continue severe for any length of time or the "flats," as soon as exposed by the ebbing tide, be covered with snow, these poor birds become exceedingly pressed for food, and are then brought into our markets in a very pitiable state. At high water they betake themselves to the adjoining marshes, following the course of the Yare, Bure, and Waveney, whose mingled waters pass throngh Breydon to the sea, and on the former stream are met with as far up as Reedham; but ererywhere fresh persecution awaits them from a swarm of gumners posted on the banks. One of the surest indications of an musually severe season, such as that of 1860 , is the alppearance of men in our streets, with large bunches of dunlins, knots, and grey plovers, suspended from sticks, the former being invariably palmed off as snipes upon the unwary purchaser. Though, of course, far inferior to the snipe, dunlins when in condition, are very good eating, but it is essential that the trail should be removed as soon after they are killed as pussible, since the gall blatder in this species is largely developed and imparts a bitter and extremely umpleasant flavour.*

* In the L'Estrange "Household Book" this species, under the name of "stynt," is frequently included amongst the shore-birds 
The appearance of these birds on the wing when in considerable numbers, like the marvellous rising of the black-headed gulls in their breeding haunts, is a sight never to be forgotten. I have witnessed it myself on Breydon, when the whole surrounding country was covered with a deep snow, and when the broad channel of the main stream with its numerous tributaries, looked black in contrast to its whitened border's. Presently a bright gleam of sunshine would alternate with the snow storms of a real winter's day, revealing a swarm of birds upon the "flats" beyond, and when these, in hundreds, rose upon the wing, and performed, as one bird, their varied evolutions, the under and upper portions of their plumage in turn presented to the eye, seemed like a streak of silvery light, or a dark cloud passing over a sunny landscape.*

Mr. J. E. Harting has so accurately described the habits of these birds when feeding on the Breydon "flats," that I am glad to have the opportunity of quoting here certain passages from his MS. notes. In September and October, 1863, he found small flocks of dunlins in the harbour, feeding in company with golden and ringed plovers in about equal numbers, with a few curlews and gulls. As soon as the tide began to flow

purchased of the "fowler" and others; occasionally as many as three dozen and a half at one time. On one occasion we find the following birds thus curiously priced:- - " It. a curlewe vd., ijj teles [teal] and ijj stynts iijd., and iij plors rjd."; and at another time the fowler received one penny for a dozen. "Itm pd to bym for a dosyn stynts, - - ij ob." [two halfpence.] In the Northumberland "Accounts," styntes are ordered " to be hadde for my Lorde's owne Mees and non other, so they be after vj a $j^{d ., " ~ w h i l e ~ s n i p e ~}$ are entered at iij a jd., partridges at $\mathrm{ijd}$., and woodcocks at $\mathrm{j}^{\mathrm{d}}$. or jd. ob. [three halfpence.]

* See Thompson's "Birds of Ireland," vol. ii., pp. 291-2 ; and "The Wild Forwler," by Folkard, pp. 115 and 316. 
" the birds became restless, shifting their ground and flying short distances to the larger islands of mud still left uncovered by the water, and whenerer they rose to fly from one patch of mud to another they always called to each other, and became silent again on re-commencing to feed." As the "muds" disappeared beneath the rising waters, the golden plovers were ustually the first to leave and wing their way to the marshes, followed very shortly by the ringed plovers and dunlins, whilst the last to quit their feeding grounds-with the exception of the various species of gulls-were the longlegged curlews, which had thus a few minutes advantage over their smaller companions. By means of a punt in the main channel on a flowing tide he was enabled, just before high water, to approach very close to these birds, and conld thus observe their actions without apparently creating alar'm; for at such times, as he remarks, " not only is their feeding ground gradually brought within narrower limits every minute, but the birds themselves are brought closer together, and are so busy feeding that they do not notice so much the approach of a punt." Then is the moment for a fatal shot, but how much more satisfactory, with no hostile intentions, to adopt Mr. Harting's plan, and sculling quietly up to them, within a few yards, watch the movements of these little sandpipers "perfectly unconstrained in their element of ooze and sea-wrack, running on the mud in the most graceful and varied attitudes." At high water he invariably found dunlins in small parties scattered about the "ronds" and marshes of the adjoining rivers. In these localities, when fired at in small flocks, the birds usually scattered themselves in all directions, and dropped again on the same marsh in different places, and with a little caution they could be flushed singly like the jack-snipes, which were commonly met with at the same time. Both at this time also, and again 
during a second visit to Yurmouth, in Octuber, 186i, he found stragglers frequenting the sides of the drains, and shot them like snipes as they rose out of the marsh "dykes." Their food at that time of year " consisted of small univalves belonging to the genera Risson and Turbo, together with the remains of minute Coleoptera and particles of grit and sand."

A novel mode of taking these and other waders, as well as many other birds that frequent our shores at night, has been adopted at Lymn, by Mr. F. J. Cresswell and others, of late years, with much success. On the flat shores of the Wash, at the mouth of the estuary, long nets, some six or seven feet deep, are stretched upright on poles, somewhere about high water mark, and the birds in their nocturnal flight strike the nets, and becoming entangled in the meshes, are taken alive in the morning. Some, however, are occasionally drowned should the tide rise higher thin is expected, or the nets be placed beyond a certain level on the ooze. From Mr. J. H. Gurney, jun., who, in December, 1862, spent a night on board Mr. Cresswell's yacht, with the view of visiting the nets in the early norning, I learn that a dark night in mid-winter is reckoned the best time for netting, and the north side of the Wash is considered most favourable. The night should be very dark and still, as the birds would avoid the nets if visible at any distance, and, in stormy weather, the poles are liable to be blown down, or even washed away. The meshes are large so that various gulls and wild fowl are caught by them, but the smaller Tringa, and even larks, are taken in some quintities, being entangled by their struggles. I have heard of as many as sixty dunlins having been secured at one haul, and on one occasion as many as one hundred and forty head, principally sea gulls. Nocturnal migrants, as well as the ordinary shore-birds of the neighbourhood, would seem 
to meet with a like fate, judging by the species which are occasionally captured.* At Holme, near Hunstanton, Mr. A. W. Partridge, of Thetford, has been also successful with these long nets† (some seren feet in deptl and raised three feet from the ground), but has there ranged them on the seaward side of the broad tidal basin, which I have before described as a favourite resort of the shore-birds at low water.

From the remarks of the lighthouse-keepers on our coast, I believe this species may be included amongst those migrants which, attracted by the light of the lamps, are killed tlirough contact with the plate-glass windows. A very intelligent man at the Lowestoft High Light, who had formerly been stationed at Offordness, assured me that "oxbirds" (a common name for the dunlin in some counties) were picked up at times in considerable numbers, at the foot of the Offord Light. Stragglers are also met with at chance times far inland, but their appearance in such localities is, I imagine, more the result of accident than clooice, as a single bird was picked up dead under the telegraph wires on the 8th of February, 1860, after a severe gale

* The following may be enumerated as having been taken by this means, and many of the birds being uninjured have been afterwards kept in confinement in the Zoological Society's Gardens, London, and in Mr. Gurney's aviaries, at Catton:-Owls, larks, golden and grey plovers, curlews, redshanks, bar-tailed godwits, woodcocks, knots, dunlins, oyster-catcher's, storm petrels, shellducks, wild-ducks, wigeons, and teal, together with black-headed, kittiwake, common, herring, and great black-backed gulls. Tho pectoral sandpiper, described as netted by Hornigold, near Lyun, was, I understand, taken in this manner.

+ A somerhat similar method is adopted at Morccimbe Bay, as Mr. J. H. Gurney informs me, but the nets, of a like description, are set on the sea-walls during dark nights. Large numbers of oyster-catchers are taken, but, singularly enough, no dunlins, although they are generally abundant on that coast.

$3 \mathrm{C}$ 
on the previous night, and, with others, was piobably driven inland by the storm a distance of some twenty miles. Another was shot in the meadows at Hellesdon, near Norwich, in January, 1864.

That these birds pass over this city on their nocturnal passage in autumn, as before stated of the golden plovers and lapwings, I feel certain from the notes I have been able to distinguish at times, either of single birds calling to their companions, or of small parties apparently mingled with other species. The most marked instance, however, of this, in my own experience, occurred on the 18tl of August, 1869, when I was awakened about two o'clock in the morning by the noise of birds, apparently purstuing a direct course over the house-tops, from east to west. On opening my window the sky looked bright and starlight, not dark and stormy as is commonly the case on such occasions, and the flight, at no great elevation, was still passing, although, as was soon apparent, the rearguard was close at hand. I remember being aware of some disturbing sound, before I became sufficiently aroused to detect the cause, and can, thererore, form no correct idea of the time occupied by this clamorous host, in passing over my house and garden. To the restward, as far as the ear could detect their cries, myriads of small Tringe were filling the air with their incessant whistlings, and the impression on my orvm mind at the time was that the old birds were calling to keep the young ones together, and that the latter, answering in low murmuring notes, occasioned the confused sound which in a remarkable manner marked the passage of these migrants. Now and then I detected the cry of the redshank, but always singly and apart from the main body, accompanying but not joining their forces; and, in like manner, apart from the rest, I conld distinguish stray dunlins by their notes, as if 
passing to and fro along the ranks, perhaps acting as aides-de-camp to this great feathered army.

I have no reason to suppose that the dunlin ever remains to breed in Norfolk, eren though Mrr. Lubbock in his "Fama" (spealing of "the stint or oxbird of our beach"), says (p. 117), " some breed as fir inland as the warrens about Swaff ham and Thetford." This remark, however, as Mr. Lubboek has recently informed me, was founded entirely upon notes supplied him by the late Mr. J. D. Salmon, with reference to the liabits of the ringed-plover and the occasioncl appearance of the dumlin in summer, abnut Thetford. Had Mr. Salmon actually found the latter breeding in that neighbourhood I am quite sure that so interesting a fact rould have been communicated with his other valuable contributions to the "Magazine of Natural History," but neither" in that journal nor yet in his MS. diary of Ornithological events, * during his residence at Thetford, is there a single entry leading to such a conclusion. Mr. Alfred Newton, also, who, living close to Thetford Warren for a good many years, had unusual ficilities for observing the species breeding there, assures me that the dunlin never did so to his knowledge, or to that of the warreners, but that a stray bird would oceasionally make its appearance there in the month of May. Thus on the 24th of May, 1850, a male bird, recognised as such by its flight and note, was seen by his brother on Thetford Warren, but it could not be found again though search was made on subsequent days; and again on the 19th of May, 1851, a female was shot on the warren. In 1853, during the flood which devastated the south-west corner of the county,

* For the perusal of these carefully-kept notes, now in his possession, I am indebted to $\mathrm{my}$ friend Mr. H. Buckley, of Edgbaston, Birmingham. 
the dumlin male its appearance among other waders, and a pair were shot by Mr. Newcome, at Hockwold, on the 6th of May in that year. In like manner on the coast, either singly or in small flocks, the dunlin is met with throughout May and June. On the 2nd of June, 1862, I shot a solitary male, at Salthouse, in full summer plumage, which frequented the brackish waters at the back of the beach, near the nesting place of the ringed-plovers and lesser terns; and at Hunstanton, in 1863, I observed small parties of dunlins on the sands between the 16th and 30th of May, and one flock of eight or nine on the 12th of June.

Most shore-gunners, as well as collectors, are aware of the difference observable in certain examples of this species, not only in size but in peculiarities of plumage, apart altogether from seasonal changes. And hence continental authors more especially have, of late years, distinguished a larger and a smaller race of the European dunlin, as has been ahready remarked of the ringed-plover.* In his "Ornithologie Europénne" (1849, vol. ii., p. 230) Degland mentions under the name of Tringa torquata, a stint which he considers distinct from the common species. He describes it as a little smaller with rather shorter bill and tarsi; the head in winter broadly streaked with blackish brown; its breeding dress brighter than that of the common stint, and the black patch on the abdomen smaller. $\mathrm{He}$ also adds that it breeds in Holland, whereas the larger species goes further north to breed. On this latter point, however, Temminck, in the third or supplementary volume of his Manuel (p. 400), quotes from Naumann to the effect that the lesser bird is the most northerly in its summer habitat, an opinion entirely opposed to that of Degland, +

* See ante, p. 95, note; extract from "Ibis," 1865, p. 465.

+ In the second edition of Degland's work (1867), the editor, M. 
and one which Mr. J. H. Gurney, to whom I am indebted for the above references, is much inclined to question. The Tringa torquata of Degland, it should be observed, answers to the T. schinzi of Brehn (1824), the T. cinchus minor of Schlegel (1810), but is perfectly distinct from $T$. bonapartii of Schlegel, the T. schinzi of Bonaparte (1828), which is figured by Yarrell, and is an American species having a distinguishing patch of white on the upper tail coverts, but not yet procured in this county, though at least four examples have been killed in England. Of the true Tringa schinzi, then, as thus distinguished, $\mathrm{Mr}$. Alfred Newton possesses a specimen killed at Yarmouth, which renders it specially worthy of notice in the present work, and after comparing this bird with one or two small dumlins in my own collection from Yarmouth, ${ }^{*}$ and with notes of examples sent me from time to time for identification from the same locality, there seems no doubt that this smaller race, although not common as compared with the large dunlin (the true $T$. alpina of Linnæus), is nevertheless a regular visitant to our Norfolk coast. I have now no question, also, that four dunlins seen by myself, at Cromer, on the 23rd of August, 1867, belonged to this small race, as I mistook them at a distance for little stints. When they approached nearer, however, to the spot where I was lying on the shingle, and, apparently indifferent to my presence, fed by the water's

Gerbe, adds, the north of Scotland, the shores of the Baltic and the North Sea, and Siberia to the breeding places of this race. Mr. A. Newton also tells me that he has found the larger race breeding in the extreme north of Norway.

* One of these killed on the 28th of April, 1858, in nearly full summer plumage, agrees exactly with Degland's description of the lesser dunlin in its nuptial dress. The abdominal patch is small, and the chesnut tints on the upper portions of the plumage, so vivid that the bird was sent me as a variety. 
edge within three yards of my feet, I at once recognised the species though struck by their diminutive forms.

To Mr. Cordeaux I am indebted for specimens from the Lincolnshire coast of what he terms "drain" dunlins, owing to the localities in which he generally finds them; but although the two I have seen do not appear referable to the smaller race, yet the habits and actions of the "drain" dunlins, as observed by Mr. Cordeaux during several seasons, are of so distinctive a character as to deserve special notice. Of these birds he writes- "I occasionally meet with a pair or two about our larger marsh drains, feeding on the narrow strips of 'warp' left between the water and the grass. I have never recognised them on the 'flats,' the resort of the common race, nor do the larger dunlins ever feed in our fresh water drains.* When flushed in the drains, in the immediate vicinity of the Humber embankment, they usually fly up the drain and not on to the 'flats,' and if towards the 'flats' will 'wing round' and pitch again in the drain. They are extremely tame and fearless, and in this respect differ singularly from the shy, wild, Humber dunlins, which, from constant persecution by the bank shooters, become unapproachable save by stratagem. I have some times sat on the drain bank watching these fearless little birds probing the mud within a few yards of my feet. They do not pack together in flocks. I have never observed more than three at the same time. They are almost always seen in pairs, and exhibit the strongest attachment for each other. I shot one of a pair on our main drain during the winter months; the distress of the survivor was most pitiful, flying backwards and forwards, and all the

* The dunlins before mentioned as shot by Mr. Harting out of the marsh "dykes," near Breydon, were of the ordinary type. 
time giving utterance to a plaintive cry, a cry which I have often thought (but I may be mistaken) differs from that used by the shore dumlins. Two birds shot on the 16th of May, showed scarcely any sign of the summer dress. All our shore dunlins, and I have inspected scores through my glass, were then in full summer plumage. Unlike the shore dunlins, which are perpetually on the move, and ever on the alert, these may be seen standing for long periods on one leg close to the water's edge, the other leg dangling loose from the body, and the head thrown back between the shoulders. I believe a pair or two may be found in this district throughout the summer." Of a specimen picked up dead on the 4 th of June, he writes, "this bird is in full summer plumage or nearly so, but the black pectoral patch is much broken up with white. It was too far gone for preservation." Mr. Cordeaux has also examined, under the microscope the respective parasites of the "drain" and "shore" dunlins, which certainly, as shown by a coloured drawing sent to me, are widely different.

As with the godwits, sanderling's, and other waders, examples of this species differ much in the date of their assumption or loss of the breeding plumage, birds killed on the same day, either in spring or autumn, often exhibiting every stage of transition from winter to summer plumage or vice versa. As a rule the sex of the common dunlins, may be determined by the bill, that of the female being almost invariably the longest, my own experience in this respect, from the dissection of a good number of specimens agreeing entirely with Mr. Jefferies' statement in the "Zoologist" for 1867 (p. 81:3); but, as I have already shown to be the case with the bartailed godwits, exceptions may be met with which would altogether mislead the collector who relied on external eviuences only. In fum fomales of the larger race now 
before me the length of bill varies from one inch and a quarter to rather more than one inch and threeeighths; and in four males from one inch full to nearly one inch and a quarter. The degree of curvature, as well as the depth of the mandibles at the base, also varies considerably.

Varieties of this bird, although such an abundant species, are but rarely met with. Mr. F. Frere, of Yarmouth, possesses a very curious specimen killed by himself on Breydon in the spring of the year, which, from its size and the form of the bill, was at first supposed to be a curlew sandpiper. Mr. Harting, however, having examined the bird, agrees with me that it is a white* dunlin, having only the scapulars and a few other feathers rust colour.

\section{TRINGA MARITIMA, Brünnich.}

\section{PURPLE SANDPIPER.}

This species occur's pretty regularly in autumn and winter, although the number seen or procured on our coast varies much in different seasons. It is also occasionally met with in spring, but that this is exceptional may be inferred from my own notes since 1850, containing but one entry to that effect: a bird killed at Yarmouth, on the 14th of May, 1853, commencing the change to summer plumage. Two were also observed by Mr. Dowell, at Morston, on the 30th of July, 1851.

* In the "Field" of September 16th, 1865, Mr. F. Hele, of Aldeburgh, Suffolk, records a perfectly white dunlin, as recently killed at Thorpe in that neighbourhood. Of this bird Mr. Harting remarks in his "Birds of Middlesex" (p. 201, note), "The quill feathers were much worn, and the bird had the appearance of great age." 
Strangely enough this species is not included by Messr's. Paget in their list of Yarmouth birds, but Mr. W. R. Fisher, in a note "on the occurrence of rare birds at Great Yarmouth," published in the "Zoologist" for 1843 (p. 182), alluding to its variable numbers, says"In 1811, I saw but one specimen, which occurred October 23rd. In 1842, from October 22nd to December 10th, inclusive, it was comparatively common." I have known the young of the year killed at Sherringham as early as the second or third week in August, but they are more generally met with during the three following months. On the 12th of January, 1861, two or three were shot on Sherringham beach, in company with knots, godwits, \&c., during severe weather; and in 1861, 1866, and 1867, one or more specimens were obtained in each year at Blakeney, Hunstanton, Yarmouth, and Lymn, in December and January, during frost and snow. A female shot on the 31st of December, 1866, on Breydon water, as recorded by Mr. T. E. Gunn, in the "Naturalist" for 1867 (p. 177) had the ovary "full of minute eggrs," and the contents of the stomach consisted of "young shrimps, small aquatic snails, and a few small stones." An adult female in winter plumage was killed at Cley, on the 30th of October, 1869, by Mr. R. Upcher, of Kirby Cane. Mr. Hunt includes this species in his "List" as occurring on Cromer beach, and states that "the specimen in the Norwich Museum, preserved by the Rev. W. Whitear, was killed at Yarnouth." Mr. Dowell has known several killed in different seasons at Blakeney, Morston, and Salthouse, between Sep'tember and January, but for the most part occurring" singly. In 1847, however, on the 17th of November, he killed six at Salthouse and saw five more, the wind at the time blowing a gale from the north and north3 D 
west. On the 25th of September, 1863, he also saw several at Hunstanton.*

This interesting species, which frequents almost exclusively the weed-covered rocks on the sea shore or the margins of tidal waters in close vicinity to the coast, has, from recent observations, been found to exhibit peculiar and distinctive actions in its search after food, for which its long prehensile feet and short but stoutly formed tarsi would seem to be specially adapted. $\mathrm{Mr}$. Gatcombe, of Plymouth, $†$ as quoted by Mr. Gould in his "Birds of Great Britain," thus describes the habits of this species when found on the rocks in rough weather: "On seeing a large wave approach it crouches and holds on the rock, allowing the spray to dash completely over it, and on the wave receding, rises and displays the greatest activity in picking up its food until another wave compels it to crouch again." As stated also by Mr. J. H. Gurney in the "Zoologist" for 1865 (p. 9468), a somewhat similar proceeding on the part of a pair of these sandpipers, killed in December, 1864, at Lancing Water, a long broadish pool lying between Worthing and Shoreham, was remarked by $\mathrm{Mr}$. Wells, a birdstuffer, at Worthing. He was struck by their habit " of dipping suddenly under water with a plunge, so much resembling that of the water rat, that when Mr. Wells first saw one of these birds perform this action, he actually mistook it for a water rat, and it was not until

* Mr. Hele, in his "Notes from Aldeburgh" on the Suffolk coast, in the "Field," of November 17th, 1866, remarks-"On November 1st I met with and killed two very good specimens of the purple sandpiper along shore between Aldeburgh and Thorpe. These are rare birds in this locality. The food consisted of small shell fish and small quantities of the organic remains of the mudcarrs."

+ See also a note on this species by Mr. Gatcombe in the "Field" of November 25th, 1865. 
after it had emerged that he discovered that the subject of his observation was a bird and not a quadruped."

According to $\mathrm{Mr}$. Gould the rich purple colouring of this sandpiper, from which it derives its English appellation, is peculiar to the winter season, and our local specimens, therefore, according to age and date of arrival, have all more or less acquired this familiar garb, but in its summer quarters in the Fœro Islands, Iceland, Greenland, Norway, and Spitzbergen, it is scarcely recognisable as the same species, when "from the crown of the head to the lower part of the scapularies, all the feathers are edged with chesnut and white, while the purple winter colouring of their centres has given place to brownish black."

Mr. Harting has kindly communicated the following description of the colouring of the soft parts in this species, as observed by him in a freshly killed example, shot on Breydon, October 30th, 1867 :-“ Iris, very dark brown; bill, brown anteriorly, yellow at the base; legs and toes, bright yellow," a very marked feature. The contents of the stomach were small univalves.

\section{CREX PRATENSIS, Bechstein.}

\section{LAND-RAIL.}

As a bird of passage the Land-Rail or Corn-Crake visits us regularly in spring, and many pairs, scattered over the county, remain to breed in the corn-fields or amidst the rank herbage of low meadows, as well as on the "ronds," and marshes bordering upon our rivers and broads.* Towards the end of April, or beginning of May,

* They do not seem to breed in the "Breck" District, though they occur there in autumn.

3 D 3 
its presence is indicated by the monotonous creaking note from which its name is derived, and by which alone an estimate can be formed of the abundance or scarcity of the species during the summer months. "Heard, not seen," is the motto of its race, and as both cornand grass-lands usually afford sufficient shelter* on its first arrival, examples are but rarely procured at that season; although, as stated by Yarrell and other authors, even this wary bird may be drawn from its coverts by simply passing a piece of wood along the teeth of a comb, in imitation of its call note. This cry is said to be uttered only by the male bird, and Selby remarks that when paired and incubation has commenced it ceases altogether; but this is quite contrary to my own experience, having heard it on summer evenings, both in June and July, and Thompson gives instances of its having been heard in Ireland throughout July and even occasionally in August. Mr. Lubbock, in 1845, described the corn-crake in his "Fauna of Norfolk," as having "much decreased in numbers," attributable, I imagine, to the same causes which have rendered the quail $\dagger$ far less numerous than formerly. The greater abundance of land-rails in Ireland than in Great Britain is attributed by Thompson "to the more humid climate and the general prevalence of meadow land;" conditions which in this county, at least, have been extensively changed through drainage and cultivation; and at the present time the localities most frequented by it are those where cultivation borders upon a low lying district, with

* According to Thompson ("Birds of Ireland," vol. ii., p. 312), the arrival of the corn-crake in the north of Ireland, has no connection with the carly or late state of the meadows, having remarked the bird "when they hardly concealed its body"; and at other times not until "two or three weeks after they were ready for its reception."

+ See ante, vol. i., p. 431, note. 
a river or smaller stream flowing through a range of rich meadows or, in the "Broad" district, those drier marshes which divide the arable land from the actual swamp. This species, even if more abundant in some seasons than in others, is never, I believe, so plentiful here as in more northern counties; $*$ but wherever their cries have been heard repeatedly during the summer inonths, some few are almost invariably lilled in autumn. As before stated, these birds frequent the swampy margins of rivers and broads, and in such localities on the banks of the Yare, near Coldham Hall, I have heard several, soon after day break, in June and July, apparently calling to one another from either side of the stream, but, as Mr. Johns remarks in his "British Birds in their Haunts," "it is not easy to decide on the position and distance of the bird while uttering its note; for the corn-crake is a ventriloquist of no mean proficiency." Of their breeding habits Mr. Gould writes in his "Birds of Great Britain :""By the time the grass is ready for the scythe, the mead bespangled with the butter cup, and the charlock well in flower, the hatching time has arrived, and the coal black young are following their parents stealthily through the grass. These active little creatures must grow with unusual rapidity, for the barley is scarcely ripe before they can fly, and the 1st of September is usually too late for sportsmen to benefit by more than a remnant of the thousands that must be bred in our islands." It by no means follows, however, that because an unusual number are found by the sportsmen at the commencement of the shooting-season that

* Selby writes, "upon the banks of the Trent below Newark, the meadows are annually visited by great numbers of corn crakes, and I have, in the course of an hour, killed eight or ten in a single field." 
therefore an unusual quantity have been hatched off in this county. Those which still remain with us at the close of the harvest, finding no shelter on our bare stubbles, frequent for the most part fields of clover seed or second crop clover, a preference which proves fatal to them in September when, unable to run, they are compelled to rise before the dogs and afford an easy shot. An abundance, therefore, of such covert in any one season, as was particularly the case in 1869, is sure to result in many rails being killed, though the birds may not really, as is commonly thought, have been more numerous than usual. It is probable, however, that migrants from more northern localities may visit us occasionally on their passage southward.* From my own notes on this species, of late years, I find that in 1854 an unusual number were received by our bird stuffers during the month of September, and the same in 1857. In the latter year I heard one calling early in May, within a mile of this city, at Eaton; and in September one or two were shot on a farm in that parish. During the same month three very fine birds were shot at Northrepps, near Cromer; at Surlingham $\mathrm{Mr}$. Pratt killed three in one day, all very heavy birds; and on the opposite side of the river Mr. Tuck shot four in one day, and five out of six a few days after, one of which weighed nearly nine ounces, whilst the others averaged eight ounces each. $\dagger$

* The Rev. R. Holdsworth informed Mr. Yarrell that he had "been at the killing of thirteen comples in one day, in Devonshire, in the month of September;" and the same author states that two sportsmen, during the third week in September, near Battle, "only a few miles from the coast, in Sussex, killed fifteen couples of land rails in one day, and seven couples the next day," but this is termed by Mr. Knox, in his "Birds of Sussex," "an unusual occurrence."

+ Yarrell gives the weight of the land-rail as "about six ounces," but states that he had seen one and heard of another, 
The present antumn (1869), as above stated, has been exceptional in the number of land-rails killed in various parts of the county. Between the 1 st and 7 th of September Mr. Gerard Barton, of Fundenhall, shot four in that neighbourhood, where he had not previously met with any during several years. Two were killed with a right and left shot at Hapton, by $\mathbf{M r}$. T. H. Edwards, and some seven or eight specimens were brought in to our birdstuffers. The reputation, however, of this bird as a delicacy for the table renders the number thus preserved a poor criterion as to the amount actually killed.

I have, on several occasions, been shown the egrss of the land-rail taken in Norfolk, but the nests are rarely found unless mown out; and on the 9th of June, 1864, I saw eight little ones in their long black down, and two eggs which had been taken in a grass field on the Kimberley estate, near Wymondham. One of the old birds was also killed accidentally by the scythe, as not unfrequently happens. In 1862 a single bird was killed near Norwich, on the 12th of October; and in 1864 three were killed in one day as late as the 25th, but these are exceptional cases, as also a bird of the year, shot on the 30th of November, 1855 ; and one recorded by Yarrell, as killed near Yarmouth, in January,* 1836. It seems marvellous that a bird so reluctant to take wing, and when flushed pursuing so slow and lagging

which weighed eight ounces and a half. Pennant remarks, "on their arrival they are very lean, weighing only six ounces, but before they leave this island grow so fat as to weigh abore eight ounces.

* In the "Field" of June 3rd, 1865, Dr. Bree gives an interesting account of three land-rails which he kept in confinement, one of which lived throughout the winter when turned loose in a walled-in garden, showing that this species when properly fed is not affected by our frosts and snow, but will thrive if allowed a certain amount of freedom. 
a course, apparently glad to pitch again into the nearest shelter, should be capable of a sustained passage over sea and land; but Mr. Gould ("Birds of Great Britain") states that on his outward passage to America a landrail visited the ship when more than two hundred miles from the Irish coast, and, after flying two or three times round the vessel, settled on the rigging:* He also quotes from a correspondent in the "Field" of November 10th, 1860, to the effect that in October, 1857, when "travelling" up the Mediterranean, and between Gibraltar and Malta, land rails frequently came on board, flying south, particularly near the Algerian and Tunisian coasts." They are also known at times to strike the telegraph wires on their nocturnal flight. $\dagger$

* This species has occurred once in Greenland according to Professor Reinhardt ("Tbis," 1861, p. 12), once in Bermuda according to Colonel Drummond-Hay and Captain Wedderburn ("Contrib. Orn." 1849, p. 86 and 1850. p. 14), and several times in the Eastern States of North America according to Mr. Cassin (Baird's "Birds of North America," p. 751). On the other hand the Carolina crake has also been recorded ("P. Z. S.", 1865, p. 196) as having occurred in Englaud. This bird is the representative in America of our spotted crake, for which it might be easily mistaken by a careless observer, especially if immature. The adult can easily be recognised by its black face. The specimen above alluded to is included by Mr. Clarke Kennedy in his recent work on "The Birds of Berkshire and Buckinghamshire," having been shot by Mr. H. S. Eyre, of Newington, near Sittingbourne ("Zoologist," 1865, p. 9510), on the banks of the Kennet, near Newbury, in October, 1864.

† In the "Field" of May 16th, 1868, Mr. W. A. Wooler, of Sadberge Hall, states that at Bitchburn Station, on the Stockton and Darlington Railway, the station master, Mr. Jaques, "has for the nine years he has been at that station, picked up nine corn crakes, which have been killed by flying against one of the seren telegraphic wires, and the spot where they have fallen has not varied above a yard. He has obtained one every year except in 1866, but in 1867 two were picked up. The invariable cause of death is by a dislocation of the neck." 
The sexes are nearly alike in colour, but the female, according to Gould, "is somewhat smaller than the male, has the grey on the sides of the head less pure, and the usual colour of the wings mixed with darker brown."

\section{REX PORZANA (Linnæus.)}

\section{SPOTTED CRAKE.}

The Spotted, like the corn-crake, visits us regularly in spring, and though chiefly confined to the "Broad" and "Fen" Districts, is by no means uncommon between the months of March and October. Considering the almost impenetrable swamps these crakes frequent in summer, the fact of their nests being but seldom found is, of course, no proof of their scarcity, and in like manner, owing to the extreme difficulty with which they are flushed, even on the mown marshes in autumn, the few examples killed yearly by the snipeshooter at that season are, I consider, an evidence of many passing wholly unnoticed.

Mr. Lubbock speaks of the spring arrival* of this species as occurring with "great regularity between the 12th and 20th of March," but of late years I have no record of their appearance earlier than the 21st of that month, and a female killed on the 23rd of March, 1866, at Ludham, was then forward in egg. During the first week in May, as recorded by Mr. W. R. Fisher, in the "Zoologist" for 1843 (p. 248), the egg's of the spotted craket have been taken in the neighbourhood of Yar-

* This species has occurred in Greenland according to Professor Reinhardt "Ibis," 1861, p. 12.)

+ The late Mr. C. S. Girdlestone, of Yarmouth, an authority in such matters, in a letter to Mr. Selby, in 1824 (for a copy of which I am indebted to Mr. A. Newton), on the provincial names of wild $3 \mathrm{E}$ 
mouth, and I have had fresh eggs from Hickling on the 26 th of that month, and have seen the young, in their black down, taken on Rockland Broad, in the last week of July. With reference also to its breeding in Norfolk, Messrs. Sheppard and Whitear remark, "We have seen a considerable number of its eggrs at Yarmouth, which, as well as its young, were found in the neighbourhood of that place, and are also in possession of an egg taken from a female of this species, which was killed in the marshes below Norwich." It seems probable, however, that they were formerly more abundant in this county than they are now, as Mr. Rising informs me he has killed seven or eight in a day at Horsey, where they are comparatively scarce at the present time.* A few years back a nest of this crake was found by Mr. A. Hamond, jun., on the margin of a reed-bed on Walton Common, near Westacre; and the small chain of fens on the river Thet, in the south-western part of the county, is also frequented by this species.

On two or three occasions I have shot this crake when looking for snipe at Surlingham, where both young: and old, before their departure in October, frequent the rough marshes surrounding the reed-beds; but in these localities even a dog well accustomed to this sport will some times be baffled altogether by the quickness with which the bird threads its way amongst the tangled grasses, or slips round the little tussocks. When too closely pressed, also, and compelled to take wing, it not unfrequently flies so low, in a line with the dog, that

fowl and other birds in Norfolk, remarks, "The common waterrails aro here called rails, but the spotted rails are called quails." In the Cambridgeshire and Huntingdonshire Fens, as Mr. Nervton informs me, spotted rails used to be known as "dotterel."

* Mrr. A. Newton tells me that the last nest he has heard of, near Whittlesey Mere, where the species used to abound formerly, was in 1849. 
it pitches again before a safe shot can be had, and then most probably it drops amongst the reeds and is seen no more. On the 4th of September, 1861, four were shot at Stalham on the same day, but I find from my notes for the last twenty years, that the large majority of the specimens brought to our bird-stuffers for preservation have been killed between the 2nd and 29th of October. On the 22nd of October', 1856, one old bird and three young of the year were shot at Rockland. About that time, I believe, the greater number take their departure for the south, but straggler's are occasionally met with throughout November, of which I have records in different seasons, on the 2nd, 9th, 16th, and 30th. I have also been assured by the marshmen that this crake may be found at times in mid-winter, but one shown me in the flesh, on the 2nd of December, 1868, is the latest I have ever known. As the birds observed thus late in the year are almost invariably in immature plumage, they are most probably the result of a late hatch, and therefore unable to join the earlier migrants.

In the "Zoologist" for 1847 (p. 1693), Mr. Alfred Nerton records the fact of a bird of this species having been picked up dead at Thetford, by the side of the Norfolk Railway, killed by flying against the telegraph wires. "One wing was broken, and the head bared of a considerable quantity of feathers." This occurred, as he has since informed me, on the 26th of October, 1846, and is no doubt the same mentioned in Morris's "British Birds" (vol. v., p. 12), although the date is wrongly quoted and the authority omitted.

There is little if any distinction in the plumage of the sexes, but the young before their departure in autumn, as described by Selby, have "the upper parts of a deeper oil green, and the white more dispersed in the form of small spots." Besides other minor differences, also, the bill wants the red colour at the base which marks the adult bird. 


\section{CREX PUSILLA (Gmelin)}

\section{LITTLE CRAKE.}

The first example of the Little or Olivaceous crake known to have been procured in this county (only one other having been previously noticed as killed in England), ${ }^{*}$ is stated in the Appendix to the supplementary volume of Montagu's "Ornithological Dictionary," to have been discovered by Mr. Foljambe "in a poulterer's shop, + early in the month of May, 1812, together with some other valuable birds, which had recently been received from the fens of Norfolk." The same authority, also, remarks, "it is probable that the Foljambean gallinule may heleafter be found to breed in the fens of the eastern parts of Great Britain."

In the late Mr. Lombe's MS. notes, supplied me by his daughter, Mrs. E. P. Clarke, of Wymondham, I find the record of "a little gallinule" shot at Buckenham Ferry, in August, 1827 ; of another, immature, at Neatishead, in March, 1828; and of a third in 1830, on

* Under the name of little gallinule (Gallinula minuta) Montagu, in the Supplement to his "Ornithological Dictionary," figures and describes a small crake shot near Ashburton, in Deronshire, in the year 1809, as new to the British list, but as the first Norfolk bird, as above stated, was subsequently described by the same author [seo Appendix to the Supplement] as a new species, under the name of Oliraceous gallinule (Gallinula foljambii), he was evidently, at that time uuder the impression that they were distinct. The Devonshire specimen forming part of Colonel Montagu's collection, is still preserved amongst the "British Birds," at the British Museum. This species, however, seems to have been first recognised and described by Pallas, in the Appendix to the third volume of his Travels, published in 1776, under the title of Rallus minutus, being the same specific name as was subsequently applied to it by Montagu when he, nearly forty years afterwards, discovered it in England, and redescribed it as new.

† In London according to Yarrell, but the locality is omitted by Montagu. 
Oulton Broad, near Lowestoft, in the adjoining county. One, if not more, of these local specimens, is most probably in $\mathrm{Mr}$. Lombe's fine collection,* although, owing to the absence of any memoranda to that effect, this cannot now be ascertained with certainty.

Mr. Hunt in his "List" of Norfolk Birds, published in Stacy's history of the county, in 1829, has also the following entries with reference to our smallest species of rails :-

"Rallus minuta, Little gallinule. Captain Custance, of Catton, has a specimen of this recently-discovered species [referring probably to Montagu] in his possession, shot by Mr. Girling in the neighbourhood of Scottow."

"Rallus Foljambii, Olivaceons gallinule. This species, originally described by Montagu, has been recently killed at Bradestone."

Unfortunately the more ambitious work by the same " author on "British Ornithology," of which portions were published in 1815 and 1822, was never completed, but amongst the plates, to which the letterpress is wanting, I find coloured representations of Rallus minutus and Rallus foljambii, which, in all probability, were drawn from the two last-mentioned Norfolk specimens. The first of these unquestionably represents an immature little crake, but the latter, from the distribution of the white spots over the back and wings, is far more characteristic of Baillon's crake in its adult plumage.

Again in the "Magazine of Natural History" for

* A specimen killed on the banks of the Thames, near Chelsea, in 1812, was purchased at the sale of Mr. Plasted's birds, by the late Mr. Leadbeater, and was believed by Yarrell to have passed subsequently into the possession of $\mathrm{Mr}$. Lombe. This, I have no doubt, is correct, as many of the rarest birds in Mr. Lombe's collection were supplied by Leadbeater; by whom also the entire series were originally mounted and arranged. 
1834 (p. 53) the late Mr. Hoy, in a notice of "some rare species of birds observed or killed in the county of Suffolk and arljoining borders of Essex, during the winter months of 1832 and 1833," briefly records the fact of "a little gallinule, Gallinula mimuta," having been shot near Yarmouth. Of this bird, however, and of no less than three others procured in the same year, I find the following important particulars in the MS. notes sent me by $\mathbf{M r}$. Joseph Clarke, of Saffron Walden.

"Crex pusilla, little gallinule. Two shot by Mr. Richers, near Yarmouth, March, 1833, in the possession of Mr. Hoy, of Stoke Nayland.* One was stuffed by Harvey, of Yarmouth, and sold for fifty shillings. Captain Glasspoole lilled two on Horsey Broad, in 1833."†

From this last date until the year 1847, I can find no rurther notice of this species as occurring in Norfolk, but on the 30th of March in that year an adult male in very beautiful plumage was killed "on the 'ronds' or wet marshes adjoining the large sheet of water at Heigham Sounds," as recorded in the "Zoologist" (p. 1777) by Mr. W. F. W. Bird, of London, the owner of the specimen. The same is also briefly noticed in that journal by Messrs. Gurney and Fisher (p. 1702). The following are the only examples I have been able to authenticate within the last twelve years. A male, in the possession of Mr. W. H. Scott, of Aylsham, was shot by Mr. J. Dickens, at Dilham Fen, on the 26th of April, 1852. This bird, which Mr. Scott very kindly sent me for examination, was just com-

* In Dr. Bree's description of the lato Mr. Hoy's collection, at Stoke Nayland ("Field," 1867, vol. xxx.), there is no mention of specimens either of the little or of Baillon's crake.

+ A specimen of this crake, included in Mr. Stephen Miller's sale Catalogue in 1853, was, I have little doubt, one of those already mentioned. 
mencing the change from immature to adult plumage, the blue-grey tints appearing on the sides of the head. On the 8th of May, 1855, a somewhat similar specimen, sex not noted, was shot at Catfield, and, like the last, in the centre of the "Broad" District. Mr. J. E. Harting also informs me that on the 25th of October, 1867, he flushed a little crake on a marsh adjoining the river Bure, about five miles from Yarmouth, but having just discharged both barrels at a snipe, was unable to secure it. The bird rose so close to him that he could mark the absence of white on the upper parts of the plumage, and from this and its small size felt pretty sure as to the species. It dropped amongst some thick reeds, and eluded all attempts to make it rise again.

With the exception only of the Bradestone bird recorded by Hunt, which, as before stated, was possibly a Baillon's crake, I see no reason, from the authorities I have quoted, to doubt the authenticity of any of the above instances. With no less than thirteen occurrences then, in one county, of a species usually considered so rare, the little crake can scarcely be regarded as a merely accidental vistant. If the habits also of the larger, and certainly more abundant species of rails, are difficult of observation, how much more so those of the little and Baillon's crake, whose small size and strictly aquatic nature afford every possible means of concealment, and render their capture at any time a mere matter of chance. Judging, therefore, from the localities in which our Norfolk specimens have been found, and from the fact that the dates, where known, correspond exactly with the spring and autumn migrations of the spotted rails, we may, I think, fairly class the little crake-and the same reasoning applies equally to Baillon's-amongst those birds of passage,* which for a

* In Mr. Lombe's notes we have two occurring in successive 
time, at least, periodically frequent our marshes. It is true the nest and egg's of the little crake have never been identified in Norfolk, nor, until the summer of 1866, was there any record of those of Baillon's crake having been taken, yet in the very same locality (Heigham Sounds), where eggs presumed to be of the latter were discovered by the merest accident, both species have been observed in spring; and both, in all probability, occasionally remain with us to breed. It should, moreover, be remarked that with one exception (the locality of which is unknown) the specimens here recorded, though procured within the bounds of the "Broad" district, were nearly all found in the vicinity of the smaller broads, or on the "ronds" bordering upon the Bure and the Yare; where it is obvious the chances of flushing them would be infinitely greater than amidst the interminable tracts of reeds which characterise our larger waters. the three examples killed in March were evidently met with on their first arrival, and might or might not have continued their journey northwards, while the one in April and the two in May would most probably have remained to breed. Again the one killed in August had possibly passed the summer with us ; and Mr. Harting's bird, in October, may have visited us on its passage southwards.

Both in the little crake and in Baillon's the sexes are alike in their adult dress, the immature birds laving the under parts of the plumage of a light brownish tint in place of the blue-grey, which they afterwards acquire. In describing, also, the chief points of difference, at any age, between these two species, of which Baillon's is decidedly the smallest, Mr. Harting accurately remarks ("Zoologist," 1867,

years, 1827 and 1828, and a third only two years later, in 1830. A more numerous arrival than usual of this species also appears to be indicated by the four specimens obtained in 1833, as recorded by Mr. J. Clarke.

t The same remarks apply equally to the next species described. 
p. 974), "the little crake in general colouring approaches the water rail, while Baillon's crake more nearly resembles the spotted crake." In the little cralie, according to Yarrell, the white spots on the upper surfice are confined to the back and scapulars, but do not extend to the wing-coverts, whereas in Baillon's crake they are much more numerous, and more generally dispersed over the back and wings. In Baillon's crake, also, the outer web of the first primary is always white, the same in the little crake being as constantly brown.

\section{CREX BAILLONI (Vieillot.)}

\section{BAILLON'S CRAKE.}

Messrs. Gurney and Fisher describe this diminutive rail as "very rare, but less so than the little crake," yet, to $\mathrm{my}$ surprise, I find the records of its occurrence far less frequent; and although a nest and eggs presumed to belong to this species, have been recently discovered, for the first time, in Norfolk, I know of no instance in which it has been killed in this county during the last twenty years. Mr. Lubbock, in his "Fauna," states that, to his knowledge, "it has been shot three times on Barton Fen, and appears far more rare than it really is, as it creeps and skulks about, and scarcely any dog, however sagacious, can compel it to fly." The same author also remarks in a communication to Yarrell, "On the 2nd of April, 1833, a fenman of my acquaintance killed an adult male of this species, upon a marsh at Dilham, in this county; it is now in my possession. Three years previously he had killed another at Barton, an adjoining parish; it was late in autumn, and the bird was in immature plumage." A specimen in Mr. J. H. Gurney's possession was thus recorded by him in the "Annals of Natural History" 
for 1842, under date of August 23rd. "About ten days since I received a specimen of that rare bird the Baillon's Crake, killed near Yarmouth ; it is a fine male." Again, in October, 1849, as Mr. Dowell informs me, he and a friend, when snipe shooting at Shropham and on Buckenham Fen, killed two of these crakes in the day. One, unfortunately, was too much spoilt by the dog for preservation, and the other he presented to the Rev. W. W. Poley, of Brandon, in whose possession it still remains. Although constantly shooting, however, in the same neighbourhood over the small chain of fens which border on the river Thet, he never met with another specimen.*

The discovery of the supposedt nest and eggs of this bird, in Norfolk, in the summer of 1866, was first announced in the "Zoologist" for that year ( $p$. 389) by Mr. J. Overend, of Yarmouth, who, under date of July 9 th, states, "On the 9 th of June a friend of mine in this town was fortunate enough to obtain in the market four eggs of Baillon's crake, $\ddagger$ and on

* Two Suffolk examples of this crake are recorded by Messr's. Sheppard and Whitear; one taken near Beccles, and the other at Nacton.

+ It should be borne in mind that although it has been taken for granted, hitherto, that the Potter Heigham nests were those of Baillon's crake, yet there is no positive evidence as to the fact. From the number of instances of the occurrence of the little crake, in Norfolk, it is quite possible the nests may have belonged to that species, more especially since no less an authority in oological matters than Mr. A. Newton, assures me he does not profess to know the difference (if there be any) between the eggs of the two species. In the case of the Cambridgeshire nest, as already stated, a hen Baillon's crake was taken on one of them.

I The only other recorded instance of the breeding of Baillon's crake in England, is recorded by Mr. A. F. Sealy in the "Zoologist" for 1859 (p.6329), in which year two nests were found in the Cambridgeshire Fens; one on the 6th of June containing six eggs, and one in the first week in August, when the hen bird was 
Saturday last [July 7th] another of my friends was so lucky as to get five eggs* of the same species." From further enquiries at the time, and communications received from Mr. R. Upcher, Mr. Crowfoot, and $\mathrm{Mr}$. Frere, of Yarmouth, I was enabled, to gather the following additional particulars. It appears that the four eggs mentioned by $\mathrm{Mr}$. Overend as purchased on the 9 th of June, were taken on that day, at PotterHeigham, or rather on Heigham Sounds, near Hickling, by a labouring man, who sold them to a lad named John Smith, at Yarmouth, who had been in the habit of collecting eggs for Mr. Crowfoot. The former was of course ignorant as to what they were, but as soon as their rarity was known, it was elicited from the man who took them that he had seen the parent birds near the nest, which was placed in a parcel of reeds growing in water, about a foot in depth. It was very small and loosely made, composed of dry rushes. A few days later Smith paid a visit to the spot with the hope of securing the nest, but found that the reeds had been cut and the nest spoiled, and no doubt the man who discovered it, was employed in reed cutting at the time. The five eggs procured on the 7th of July were also taken in the same locality, but of these, unfortunately three were broken. What became of the last nest I cannot say, but the two were most likely constructed by the same pair of birds.

taken on a nest, which had seven eggs. Specimens of this crake were also killed, during that season, in the same locality where, at the same time, spotted rails were unusually plentiful.

* Of the first four eggs taken on the 9th of June, purchased by Mr. W. M. Crowfoot, of Beccles, one only remains in his possession, he having most liberally parted with the remainder to Mr. A. Newton, Mr. R. Upcher, and myself. Of those taken on July 7th, three were broken, and of the other two, one is, I believe, in Mr. Overend's possession, and the other in the collection of Mr. A. Crowley, of Croydon.

3 F 2 


\section{RALLUS AQUATICUS, Linnæus.}

\section{WATER-RAIL.}

The common Water-Rail* is both a resident and migratory species in Norfolk, the birds which remain with us throughout the winter receiving considerable accessions to their numbers in March and April; and though a large portion of those bred in our marshes pass southward again at the close of the breeding season, migratory flights from the north are met with at intervals in autumn and winter. In support of this view of the habits of a bird not easy of observation at any season, I may state that between the middle of March and the first or second week in April, it is customary to find several couples of rails in the Norwich market, hanging for sale with the snipes that simultaneously make their appearance in our marshes. From that time until the close of the breeding season they are pretty generally dispersed over the county wherever moist localities afford sufficient harbour; and though, of course, most abundant on the Broads themselves, are known, either by their cries or the chance discovery of their eggs and young, to frequent the margins of our inland Meres, wet commons, and even rough sedgy watercourses. That their nests should be but rarely found on our larger Broads, can be no matter of surprise to those acquainted with their haunts in such localities, but in this county, at least, their eggs are by no means of such rarity as might be inferred by Yarrell's remark that he "never possessed but two-one from Norfolk and one from Cambridgeshire -and never saw more than three or four more." In the

* I know of no provincial name for this species in Norfolk besides that of rail, but in Halliwell's "Dictionary of Provincial Names," \&c., the term "Bidcock" is applied to the water-rail, with Drayton as the authority. 
"Annals of Natural History" for 1839 (vol. ii., p. 78) is the following description of a nest of this species taken by Mr. John Smith, in the summer of that year, in the neighbourhood of Yarmouth, but the exact spot is not stated:- "The bird had selected for her nest a thick tuft of long grass, hollow at the bottom, on the side of the reed pond; the nest, about an inch and a half thick, was composed of willow leaves and rushes; it was so covered by the top of the grass, that neither bird, nest, or eggs, could be seen; the entrance to and from the nest was through an aperture of the grass, directly into the reeds, opposite to where any one could stand to see the nest." After minutely describing the appearance of the eggs, which, being now pretty generally known, it is here unnecessary to repeat, the same writer remarks:- "On the 20th of June I found another nest in the same reed-pond; the eggs were destroyed; this nest was built amongst the reeds and very near the water. On the 10 th of July I obtained a third nest from the same place, of eleven eggs, within two or three days of hatching, the nest and structure much like the first."

Two eggs in my own collection were taken with others by the Rer. W. S. Hore, on Horsey Mere, in the summer of 1850 ; and I have occasionally known them offered for sale in our market, with those of water-hens, coots, and grebes. $\mathrm{Mr}$. A. Newton informs me that on the 15th of May, 1853, a nest with nine eggs was found at Downham, close to the river which there divides this county from Suffolk, and that on the 8 th of June in the same year a nest with six eggs was found in Feltwell Fer. in Norfolk. I have also two eggs of this species from the neighbourhood of Diss, which were taken in 1860 during the first week in June, from a nest which contained nine; and in 1862, about the first week in May, three nests were found at Upton, near Acle, containing six, seven, and eight eggs respectively. 
Again on the 1st of May, 1863, I was shown three young water-rails in their black down, which had been found in the same locality (one of our smallest broads) as the eggs of the previous year. From the early date at which these youngsters were hatched, and the eggs at Diss being taken in June, I presume that this species has, at least, two broods in the year; and that it breeds early is proved by the fact that a nest found by Mr. J. E. Harting in Sussex, ${ }^{*}$ in 1868, contained seven eggs on the 11th of April, whilst in other instances he has met with them only in June and July. I saw a nest of this rail on the 17th of May, 1867, amongst some thick reeds on East Walton Common, near Westacre, but no eggs had been laid. From Mr. A. Hamond, jun., however, I learn that some have been taken in other seasons from this spot.

Mr. Lubbock, in his "Fauna," thus alludes to "the peculiar and explosive cry," as he terms it, of the waterrail during the breeding season. "Some years back a youth, the son of the ferry keeper, at Surlingham, told me he knew of a rail's nest. We went towards the Broad together to inspect it. As we walked forward, I once or twice heard a noise, the cry of some bird unknown to me; and on questioning my guide, he answered at once, 'It is the rail crying out.' It was so loud and singular a note that I doubted so small a bird having such power of clamour; but on creeping up gently behind some alders, I could see the rails at intervals as they played about in the vicinity, and satisfied myself

* This nest was found in the parish of Harting, in Sussex, in an old moat, which three hundred years ago surrounded the house of Sir Anthony Windesor. It is now nearly dry and much overgrown with willow, sedge, and coarse herbage. The nest was placed at the foot of a willow clump, neatly composed of dried flags without any lining, and almost concealed by the overhanging flags by which it mas surrounded. 
that they produced the cry in question. I think that the male bird only was thus noisy; but from the long herbage and reeds from which they only emerged at intervals, am not certain on this point; the nest contained seven eggs." I have never been fortunate enough, in like manner, to observe this bird when uttering its note, although, hidden in a reed-bush, I have witnessed their stealthy movements close at hand; or, through a good glass, have watched the actions of a little family group disporting themselves all unconscious of a looker on; but the cry with which I am familiar as that of the water-rail, and which has been pointed out to me as such by the marshmen at Surlingham and other places, is alike remarkable for its power and character, and when heard in the stillness of a summer's night is searcely less startling on those lonesome waters than was once the boom of the bittern. On the 17 th of July, 1869, between twelve and one in the morning, I listened to the cry of this bird at intervals for more than an hour on Surlingham Broad, and with a thick white fog enveloping the reed-beds and marshes, the sound struck me as far more resonant or explosive than I had ever noticed before.

The departure of a portion, at least, of our home-bred birds takes place probably about the same time that migratory flights from more northern localities* arrive on our coast, in autumn. Judging from my own experience and notes of such occurrences, this southward migration varies somewhat as to date in different seasons. On two or three occasions, when snipe-shooting at Surlingham, I have found these rails scattered all over the drier marshes, surrounding the broad, and either threading their way between the tussocks of

* In Iceland, according to Faber (Prodromus der Isländischen Ornithologie, p. 32), the water-rail is a resident bird, leading a dreary life in winter, near the hot springs in which that island abounds. 
grass or hidden in the thick herbage and tangled brushwood at the foot of small alder or sallow bushes; while at other times, should a chance shot be obtained, the bird is almost invariably flushed near the water's edge, off the mown "hoves," or from the sedges fringing the larger reed-beds. I have never known them remain in these numbers for two successive days, but, like woodcocks on the coast, resting after their nocturnal flight, they afford ample sport at the time. At Surlingham, on the 29th of October, 1853, I fell in with one of these flights, and had I not been more anxious to kill snipes than rails might probably have made a good bag; but after shooting two couples and a half, which, in spite of their abundance, took some time, so reluctant were they to take wing, I left those marshes for better snipe grounds, to the evident disgust of the marshman's retriever, which, judging by the "expression" of its tail, had been enjoying this game of hide and seek to its heart's content. As a proof, however, of the numbers that may be killed in this manner, I remember that some years since Mr. Henry Dowson, then of Geldestone, Suffolk, shot ten couples and a half of waterrails at Surlingham, in one day. This was towards the end of September, but that these migratory flights arrive thus early, at times, is proved by the fact that in September, 1846, Mr. Dowell received from Blakeney a water-rail, which had been caught alive on board one of Mr. Brereton's vessels, in the middle of the German Ocean. Others evidently make their passage* in Novem-

* Mr. Knox in his "Ornithological Rambles in Sussex" p. 240) notices the arrival of these birds on the beach at Brighton during the period of their vernal migration, at which time specimens are not unfrequently caught alive in the areas and gardens facing the sea, allured during the night with other migratory birds "by the long line of gas-lamps which extends, almost without interruption, from Brunswick Terrace to Kemp Town." 
ber, as shown by their being very plentiful in our marliets or in the hands of our birdstuffers at times during that month; and on the 27th of January, 1867, during serere weather, a bird of this kind, probably attracted by a light, flew into the open door of a house at Caister, near Yarmonth, and was captured. In the spring of 1863 I was shown by the lighthouse keeper, at Hunstanton, a water-rail, which had been found dead at the foot of the building during the previous winter; nor was this the only instance of the kind he had met with in this species. At Beeston, near Cromer, immediately on the coast, Mr. T. W. Cremer informs me they are not uncommon during the winter months; and in January, 1868, during frost and snow, Mr. F. Norgate found several at Sparham, near Norwich, dropper about in the smaller drains, where he scarcely expected to find a water-hen. In spite of the migratory nature, however, of this bird, some few, as before stated, remain with us throughout the year, and brave the sharpest winters. I have shot them both on the broads and by the sides of our rivers and smaller streams, when the ground has been covered with a deep snow, and the chammel completely frozen over. Why these stragglers should remain to incur the dangers and privations of such "hard times" is quite inexplicable; but when concealment is impossible amongst the sedges, beaten down by the frost and choked with snow, * and escape

* St. John ("Natural History and Sport in Moray"), under date of December 3rd, 1817, states that a water-rail flushed by him from a ditch when snow was on the ground, alighted again in an adjoining field, and immediately endearoured to make its way back to the water from whence it had flown. A large gull perceiving the bird struggling through the snow pounced down upon it, but the rail flung itself on its back and fought with bill and claws, even jumping up at and pulling feathers out of its formidable antagonist. This was repeated again and again, as often as the gull tried to seize upon it. But at last the gull was driven off by Si. John, and the plucky little rail reached its haunt in safety.

3 G 
by diving is prevented by the ice, the unfortunate rail falls an easy victim; either compelled to take flight, or, not unfrequently captured by the dog.

Mr. A. Newton tells me that on the 16 th of February, 1856, during frosty weather, he had a live water-rail brought to him at Elveden. As it had been a good many hours without food, and there was not the least chance of its obtaining any if he liberated it, he put some soaked bread into its bill, and in a few minutes, while he yet held it in his hand, it began to pick bits of bread from his fingers. On his setting it down on the floor with a sancer before it it went fairly to work, and soon made itself at home, ruming about the room and showing great inquisitiveness. It examined every corner, tried to scramble into all sorts of impossible places, perched on the cross rails of chairs, jumped up to the windows, when, of course, it was much surprised by the nature of glass; finishing every tour of inspection with a visit to the saucer, and now and then walling deliberately to the fireplace, where it shook its feathers and dozed for a few moments in evident enjoyment of the warmth. With all this, however, it only lived a short time.

Messrs. Gurney and Fisher mention a curious instance of a water-rail being found dead in a meadow at Earlham, near Norwich, with a small fish called the "Miller's thumb" (Cottus gobio) fixed in its throat, the bird having been choked in the attempt to swallow it.* Varieties of this species are very rarely met with. In February, 1863, I saw a rather remarkable-looking specimen which had been shot at Ling'wood, and had the upner part of the liead, neck, back, and wingcoverts, thickly sprinkled with white feathers.

* Mr. Jeffery in his "Ornithological Notes from West Sussex" ("Zoologist," 1868, p. 1034), remarks, "The water-rail is a fish eater; three small 'Miller's thumbs' or 'Bull heads' were found in the stomach of one." 


\section{GALLINULA CHLOROPUS (Linnæus).}

\section{MOOR-HEN,-WATER-HEN.}

Abundant as is this familiar and most interesting species throughout the lingdom, it is perhaps nowhere so numerous or so generally dispersed as in Norfolk. Not only in its main strongholds, on the Broads and Mleres, does it find the needful shelter of reeds and rushes, but the deep sedgy ronds of our slugrish rivers, extending for miles on either bank, are a constant resort in summer, and wherever, as is peculiarly the case in the vicinity of Norwich, some smaller streams winding their tortuous course through the low meadows, abound in alder and osier carrs, reed-beds, and islands of tangled brushwood, water-hens may be met with at all seasons, and, though thimned by the sportsman or an unusually severe winter, will soon recover their former abundance. Nearer still to the habitations of man, this bird, with its strange mixture of shyness and sociability, frequents the reedy margins of our inland lakes and other ornamental waters, however limited in extent, provided only there is sufficient harbour-some sheltering nook of rank aquatic herbage and a surface coated with weeds and floating plants. The ancient moat half choked with regetation, the home pond, or pit-hole in the fields, and even, at times, the centre of a plantation at a distance from water, will form the home of these versatile creatures, which, adapting their habits to circumstances, will roost as readily in a tree, shrub, or fence, as amidst reeds and rushes. The busy sound of a water mill, or foundry, or the noisy traffic of a railroad skirting their haunts, fails to disturb their equanimity, for as the train rushes past we catch sight of them for an instant from the carriage window, quietly picking about in an adjoining ditch. $3 \div 2$ 
But clear that ditch of its weeds, and trim the banks of the flagrs and sedges, and, for a time at least, you banish. the water-hens more effectually even than by the use of the gun.

Mr. Lubbock truly remarks, "though this bird is so often found exactly in the same situations as the coot, although they nest and bring up their young together, no birds differ more in habits." The sights and sounds of human lrabitation, which drive the coot still further into its reedy fastnesses, have attractions for the wary but semi-domesticated water-hen, which feeds with the marshman's fowls, breeds near his garden, and revenges itself for the loss of an early sitting of egos by repeated raids upon his vegetable produce. In fact the waterhen has a great partiality for gardens if adjoining the main river, or skirted by a brook to which they can retire on the least alarm; and, whether in outlying plantations, or in close vicinity to the keeper's cottage, will devour barley and other grain with avidity, for, as the author above quoted states, they "will arrive at the keeper's whistle even before the pheasants"; and this not merely when hard weather has deprived them of other means of subsistence.

In the Northrepps plantations, near Cromer, a few of these birds are found constantly in the breeding season, though rarely seen during the winter months, and their nests are frequently placed from six to ten feet from the ground in the silver firs, from which the young are, no doubt, conveyed to terra firma in the prehensile feet of their parents.* There are only a few small pits of water in the parish at all adapted

In the "Zoologist" for 185t (p. 4367), Mr. Samuel Gurney, of Carshalton, states that a water hen which had built on the branch of a fir tree overhanging the river, and a few feet above the water, was seen to "fly down with two of her young brood, one in each foot, from the nest." 
to the ordinary habits of this species, but they secm to content themselves almost entirely with the supply distributed about in shallow pans for the pheasants. In these coverts a few years back, a very remarkable display of instinct, amounting almost to reasoning power', on the part of a water-hen, was witnessed by John Gally, a gamekeeper on the estate, the particulars of which, as related to me, I have no reason to question. The pheasants are accustomed to feed from wooden boxes, which, to prevent small birds from eating the grain, are so constructed that the lid only opens by a lever when a pheasant perches on the projecting rail in front. The waterhen having observed the pheasant's method of feeding also perched upon the rail, but found its own weight insufficient to raise the lid, and therefore, after one or two unsuccessful attempts, went off in search of its mate, and, returning to the box, the weight of the two together effected the desired purpose, and enabled the sagacious bird to obtain its well-earned meal. Extraordinary as this ingenious device may appear on the part of this water-hen, it is apparently not a solitary instance, as an anecdote similar in almost every particular with respect to the same species, is recorded by the late Bishop Stanley in his "Familiar. History of Birds." It would seem, however, from the following note in the "Zoologist" for 1854 (p. 4255), by Mr. H. T. Partridge, that, although fond of appropriating the pheasants' food whenever opportunity offers, the water-hen is not always impressed with a proper sense of its obligations, either to the gantekeeper or the young pheasants:- "At the beginming" of last July, the keeper having lost several pheasants about three weeks old, from the copse, and having set traps in vain for winged and four-footed vermin, determined to keep watch for the aggressor, when, after some time, a moorhen was seen walking about near 
the copse; the keeper supposing that it only came to eat the young pheasants' food, did not shoot it until he saw the moorhen strike a pheasant, which it killed immediately, and devoured all the young bird except the leg and wing bones.* The remains agreed exactly with those of eight found before."

Though sombre in its general colouring, and prone to concealment on the least intrusion upon its haunts, the water-hen, whether in its natural element or traversing with its long wide spreading feet some floating raft of decayed vegetation, forms a conspicuous object owing to the pure whiteness of the under tail-coverts, which contrast so sharply with the dark brown and grey of the back and breast feathers. Thus, when flirting their tails up and down and nodding their heads with a quick nervous action as they pick right and left at any insect atoms in their path, this species may be readily distinguished at a considerable distance, and a nearer view presents the bright colours of the beak and legrs.

Their nests, which are too familiar to need much description here, vary considerably according to circumstances in the style of construction. The rough loosely formed mass of reeds, flags, and rushes, which in some localities may easily pass unnoticed from its similarity to the dried litter around, is very different to that neatly made rush basket, almost as highly finished as a coot's nest, which we find occasionally amongst the outlying reed stems. Some also may be seen inge-

* Mr. Gould states in his "Birds of Great Britain," that a similar instance was witnessed a few years back ou Sir Morton Peto's estate, at Somerleyton; and a keeper at the Zoological Society's Gardens, described this species as very destructive to the young ducks, eren attacking the old ones if they came to the rescue, and as frequently nesting in the boxes erected for wildfowl on the various ponds "when not eren a goose dare approach within some yards of them." 
nionsly arched over with the young reeds as if to conceal the eggrs, whilst others are almost carelessly exposed to view; and at times a pretty contrast in colour is shown when both "green and withered leaves have been woven into the structure.* Many as are the dangers to which the young are exposed from four-footed vermin, pike, and I suspect eels as well, one ceases to wonder at the abundance of this species, when from five to ten egg's constitute a sitting, and when, if undisturbed, as many as three broods are reared in a season; occasionally, no doubt, two birds will lay in one nest, but on examining several on the same day in spring, I have been much struck with the variation both in number and size of the eggs laid, in some nests perhaps only four or five eggs, but those hard sat upon. The young in their black down, as depicted in Mr. Gould's plate in his "Birds of Great Britain," are most beautiful little objects, with their bright but evanescent tints about the head and bill, and there are few prettier sights in summer than a family group disporting themselves amongst the broad leaves of the white and yellow water lilies, or snatehing their insect food from the delicate blossoms of the water ranunculus. Messrs. Sheppard and Whitear state that they have observed nestlings when only a few days old, "rumning about upon the tops of the weeds, and picking insects from them," but that a pair hatched off under a hen, by Mr. Youell, of Yarmouth, took their food " rrom the bill of their-foster mother, and it was not until they were several weeks old that they attempted to pick food from the ground."

* The Rev. J. G. Atkinson, in his "Sketches in Natural History" (p. 42), describes a nest of this species which was lined with the last year's oak leaves, "regularly arranged all round and their points directed npwards." Bishop Stanley also mentions one which was built near a garden, and surrounded, as if for effect alone, by a brilliant wreath of scarlet anemones. 
As early as the 2nd of April, 1846, after a mild winter, Mr. Blofeld found two young nestling waterhens dead, in the sedge fen, at Hoveton, which were then, at least, two or three days old, and I have seen the young in the down with young birds about three-quarters grown, at the end of June, and other nestlings even as late as the 29th of August.* The Rev. J. Burroughes informs me that he has seen a young bird of the first brood assisting its parents by bringing materials for a second nest, and the second brood, when hatched, are also, in part, fed and fostered by their older brothers and sisters; whilst additional nests are constructed to meet the requirements of the family so rapidly increasing in size and numbers. Instances have been known of water-hens raising their nests to avoid the consequences of a high tide; previous losses from the same cause having instinctively led them to adopt such a course. With a like motive, no doubt, the overhanging boughs of willow and other trees, a foot or two above the surface of the water, are not uncommonly selected for nesting purposes, as well as even loftier situations. $\dagger$

* Mr. W. Jeffery, jun., in his "Ornithological notes from West Sussex," in the "Zoologist" for 1866, gives the following dates from his own observations of three broods hatched by one pair of water-heus during that year.-April 1st, first brood hatched off; April 23rd, a second nest completed and eggs laid; May 20th, second brood hatched; June 20th, the old birds drove the first brood away; 15th of July, a third brood hatched. These three broods were thus hatched in a period of about eleven weeks.

† "Rusticus," in his "Letters on Natural History," edited by Edward Newman, F.L.S., gires an account of a moorhen's uest, which he discovered on an island, placed some twenty feet from the ground, in a spruce fir-tree. The island itself was frequently flooded. Mr. A. Newton also informs me that he has on more than one occasion found this bird's nest in a fir-tree at a considerable height from the ground, once at Culford at least twenty feet. 
I quite agree with $\mathrm{Mr}$. Atkinson that the water-luer, unlike the dobchick, more usually seeks safety in flight than by diving, but both methods are adopted under different circumstances. If suddenly surprised on her nest, the hen bird takes to flight, but if arvare in time of some approaching danger, she invariably, I believe, dives from her nest as the course lenst likely to draw attention to the spot; and the eggs will then in all probability be found covered, a precaution more particularly adopted in exposed situations. So quietly is her exit made that a slight bead on the surface alone indicates her course under water, and till all danger has passed she shelters amongst the adjoining herbage, with probably only the tip of the beak out of water. This "state or posture of submergence," as Mr. Atkinson calls it, is a marked characteristic of this species, and one which enables it to escape observation in spots where no other means of concealnent exist. In wide open drains, for instance, the appearance of a slight bead on the water as one approaches the bank, raises a suspicion of either a water-hen or rat, and a dog well accustomed to the sport, will readily discover the bird's hiding place, by scenting it from above, or swimming close. under the bank, thus compelling it, however reluctantly, to take wing. The water-hen till then, holding on with its feet to the weeds under water, has probably protruded only a portion of its beak in some crevice of the bank, and though breathing with difficulty, would thus in most cases escape observation. In clear water, I have more than once detected a bird in the act of hiding in this manner, and have taken weeds from the clenched feet of one shot under such circumstances. When shooting at Keswick, near Norwich, where these birds are very plentiful in the small carrs and osier grounds by the river, I have watched their habits with no little interest. Frequently when taling a stand at the further end of $3 \mathrm{H}$ 
the covert, I have seen one or two, alarmed by the noise of the dogs and beaters, run swiftly to the edge of the water, and slipping noiselessly off the bank, secrete themselves amongst the submerged roots. Those too closely pressed by the dogs will either take a short flight to a fresh patch of reeds and rushes, diving the moment they touch the water, or, mounting up, seek concealment in some accustomed roosting place, amidst the branches or ivy-covered stems of trees; and I have thus counted as many as seven water-hens, at one time, hiding amongst the foliage of the dark firs. As remarked, also, by $\mathrm{Mr}$. Atkinson, the water-hen when flushed, and seeking shelter in a hedge, drops into "the thickest and bushiest part of it several feet from the ground, thence threading its way to the bank or ditch below, unlike the partridge, which at once seeks shelter at the bottom; but the following curious incident shows that this peculiar habit is not altogether unattended with danger. On one occasion, in a thick fence, at Framingham, near Norwich, Mr. W. Bligh discovered a water-hen suspended head downwards, a stout bramble having caught in the feathers of one side and become so twisted in by the struggles of the bird that escape was impossible; and it thus hung till it died. This was evidently not long, as the feathers were but little soiled by its mutings, and the body was in good condition.

In speaking of the various dangers to which the young of this species are exposed, I omitted to mention the heron amongst their natural enemies, but there is no doubt that this voracious bird devours both nestling coots and water-hens when opportunity offers. Mr. Selby, on the authority of Mr. Neill, of Cannonmills, near Edinburgh, states that a winged heron, kept in a garden by the mill-pond, used to swim out to a willow-tree that had fallen over the water, and take young water-hens 
from a nest built on the projecting branches. The following aneedote also proves that even adult birds, if wounded or otherwise unable to escape, fall victims to the heron's carnivorous appetite. Mr. T. H. Edwards, when shooting by the river at Keswick, near Norwich, on the 7th of December, 1869, mortally wounded a water-hen, which fell close to a heron that was standing by a drain in an adjoining meadow. The heron instantly rushed at the water-hen, and first striking it with its beak, seized and carried it off to another field, where it was seen to place its feet on the bird and endeavour to tear it to pieces with its bill. In order to scare it from its prey, Mr. Edwards approached as near as he could and fired off his gun, when the heron again seized the carcase, and this time flew off with it to a considerable distance, so that further observation was impossible. In the act of flying with the water-hen in its bill, the heron had a most unnatural appearance, the neck seemed too weak to support such a weight, and was consequently directed forwards, and downwards, instead of being thrown back as usual between the shoulders. The weather up to that time had been mild and open, so that extreme hunger could scarcely account for this unusual proceeding.

Unlike the coots and grebes, water-hens on the broads are but rarely seen upon the open waters, preferring the close vicinity of the shore, or the narrow channels between the reed-beds, with safe harbour on either side. If surprised on the sedgy ronds bordering the reedstems a scuttling movement of both wings and feet brings them at once into covert, whilst those still further from the shore rise on the wing, and flapping hurriedly over the water leave a trail on the surface with their dipping feet. There are times, however, when the water-hen, mounting well up, takes a prolonged flight to some other portion of the river or 3 н 2 
broad, and when its pace indicates the same latent power's possessed in no small degree by our migratory rails, incapable though they appear under ordinary circumstances of sustained exertion on the wing. The voluntary nocturnal flight* of this species also in summer, when its peculiar cry strikes upon the ear as it circles round and round over its marshy haunts, is in like manner in direct contrast to its ordinary habits by day.

Of the numbers bred annually on the broads themselves it is impossible to form any conception from the few which may be seen here and there in the day time; it is only in the dusk of a summer's evening, when they steal from their hiding places, and are either dimly seen, threading their way against a dark background of sedges, or clearly defined for an instant as they pass from shadow to shadow, through the last gleam of daylight on the water, that any approximate idea can be formed. At night, also, their presence is indicated, on all sides, by their loud notes and constant splashings and rustlings as they play amongst the reeds.

Whilst the coots when fairly frozen out on the broads, quit their summer haunts, to a bird, for the coast and its saltmarshes, the water-hens, as Mr. Lubbock remarks, " either not having inclination or ability to migrate, are terribly cut up." Many, it is true, betake themselves to the adjoining fields and stack-yards, but others still remain till every pool is frozen over, when starved alike with cold and hunger they fall victims in their enfeebled state to the carnivorous tastes of the grey crows and four-footed vermin. Though scarcely to be termed gregarious at any other time, they collect

* Messrs. A. and H. Mattherrs, in the "Zoologist" for 1849 (p. 2.132) drew attention, from their own observations, to this habit of the water-hen, which has been rarely noticed by authors though mentioned by Gould in his "Birds of Great Britain." 
together in hard weather, and Mr. Lubbock speaks of forty-three having been seen during a severe frost in one open splash of water at the end of an alder carr. In Jinuary, 1867, when a deep snow, drifting in places with a high wind, stopped all trafic for a time, and was followed by several days of intense frost, these birds suffered severely in exposed districts. At Surlinghim many were picked up in the fields and lanes, either dead or dying, in a sadly emaciated state. Others were found on the broad itself frozen to the ice by their quill feathers, and in some cases the poor birds had literally torn themselves away, leaving portions of their tails and other feathers adhering to the ice. The grey crows, more than usually mumerous, were very busy in despatching these unfortunates, but a trap being set, baited with a dead waterhen, one of the crows was caught, and his cries, acting as a caution to the rest, they all disappcared and were not seen again on the broad for a considerable time. A sure indication of "hard times" is the appearance in our markets of numerous coots, water-hens, and waterrails, the two latter by no means to be despised for the table; indeed a young water-hen in good condition and properly dressed is equal in flavour to many species of wild-fowl.

Pied varieties are so rarely met with, that I have never seen more than one in Norfolk, the same mentioned by Mr. Lubbock, which was killed at Ranworth by the late $\mathrm{Mr}$. John Kerrison in the winter of 1844 , and is still preserved at the hall. This bird is prettily mottled with white on the back and wing coverts, and the extreme balf of each wing, including all the larger quills, is also white. If in this respect, however, the water-hen is not given to variation, it is nevertheless subject to a strangely abnormal condition of plunage, affecting alike the tints and the 
texture of the feathers. My attention was first drawn to this curious fact from the examination of a bird, now in my collection, which was killed at Lakenham, near Norwich, on the 16th of March, 1863, and may be thus described:-All the upper parts of the plumage, including the head, neck, back, scapulars, wing and tailcoverts, secondaries, slightly, and the quill feathers of the tail are reddish orange over shades of greyish-black, this singular appearance being caused by each feather having the basal half black, the anterior portion only having a reddish hue; and that most vivid on the back and shoulders. Primaries dull black, the first quill feather having the outer web, as usual, edged with pure white. The feathers of the flanks are also tinged with orange red, becoming brighter in colour towards the vent; two or three feathers, however, on either side are partly white, but not conspicuously so as in ordinary specimens. Sides of the head, above and below the eye, dull black, slightly tipped with greyish white, as also the chin and throat, but the greyish white tips on the latter are more defined. The rest of the under parts greyish-white, here and there tinged with orange, but the basal part of each feather greyish black. Under tail-coverts white, but with only a few feathers left to represent this striking feature in the ordinary plumage. Legs and feet green without the red bar above the tarsus; bill greenish yellow, anteriorly, dull red on the base and frontal shield. The whole of the plumage has a worn and ragged appearance, resembling rather hair than feathers, owing to the absence of the interlacing filaments from the anterior portion of the vane of each feather, and in passing the hand over the back of the bird (peculiarly soft and smooth in its normal state), its roughness reminds one of the sensation experienced in stroking a wiry coated terrier dog.

The cause of this strange condition of plumage is, 
I think, clearly pointed out in the following notes by my friend Mr. F. Kitton, of this city, who, after a careful microscopical examination of the feathers in this specimen as compared with those of the ordinary type, remarks, "the microscope does not show any organic difference between them. The quill and shaft are alike in both, as are also the down and lower barbs. The upper barbs are divested of the pennules [the barbules and other minute subdivisions of the web or vane] thus producing the alteration in colour and rough appearance of the bird. I believe that from some physical cause the bird has not moulted, and the more exposed portions of the feathers are worn and broken, as would naturally be the case with feathers retained for two seasons. 'The pennules on the upper barbs are rubbed off, and the tips of the barbs absent; precisely the same appearance is produced by drawing the barbs of a perfect feather between the nails." I may add that I dissected this bird at the time, but failed to discover any internal evidence of disease. It proved to be a female, the ovary apparently healthy, and containing a number of minute eggs about the size of millet seed. A second example, which I purchased recently and was said to have been killed some few years back, at Ludham, differs only in being much smaller, the former being the usual size of an adult water-hen, the latter a bird about three quarters grown. From the colour of the bill and legs, however, the Ludham example would seem to be adult, and its smallness may be partly owing to a contraction of the skin in stuffing.

Mr. A. Newton, as I have recently ascertained, also possesses a specimen of this kind, which was lilled near Buckenham House, Norfolk, in November, 1857 ; and in some notes supplied me by the Rev. H. T. Frere, of Burston, I find two water-hens recorded as light fuwn- 
coloured varieties, which were no doubt similar in character to the above, as Mr. Frere remarks, "the person who killed them had a fancy that they were a hybrid between the water-hen and common corn-crake," an idea more than once mooted by friends (but little acquainted with ornithological matters), on examining my specimens. In 1864, Mr. J. H. Gurney observed one in a birdstuffer's shop at Reading, which had been procured in that neighbourhood; and another, killed at Bramford, near Ipswich, Suffolk, on the 16th of December, 1847, is minutely described in the "Zoologist" for 1848 (p. 2067) by $\mathrm{Mr}$. F. W. Johnson.* It is somewhat remarkable that this strange condition of plumage should be found in so many instances in birds of this species, for although examples in other genera exhibit, at times, indications of imperfect moulting, I am not aware of any similar case in which the character of the bird is so entirely lost owing to a mere physical defect.

A curious instance of malformation in the feet of a water-hen shot at Pulliam, in 1847, is thus described by Messrs. Gurney and Fisher in the ("Zoologist," (p. 1601):-" Each of the hind toes of this bird possesses a second claw, which on the right foot merely springs from about the middle of the true toe; but in the left, is attached to a second toe, which proceeds from the original one, about half-way from its junction with the tarsus. The supplemental toe and claws are in each case attached to the outside of the true hind toe."

In the L'Estrange "Household Book" this species is

* This is the same bird mentioned by Morris, ("British Birds," vol. $\nabla .$, p. 43), although his description is not quoted from the "Zoologist." It is singular, howerer, that so marked a peculiarity in the plumage of this species, should have escaped the notice of other British authors. 
once, and only once, alluded to, under date of 1583"Itm a watter hen kylled wt the gun."-A first victim evidently to the then new weapon of destruction, and alfording to the unstilled gunner of those lays, the easy shot still sought for by the school boy or other tyro in the use of firearms.

\section{FULICA ATRA, Linnæus.}

\section{COOT.}

The Coot, though an abundant species in Norfolk, is not so generally distributed as that last described, preferring the open waters of the broads and meres, extensive lakes, and large reedy ponds, to the smaller coverts that content the more familiar water-hen. Except in close vicinity to the broads themselves, it is seldom seen on our rivers, but in the neighbourhood of Surlingham and Rockland, on the Yare, its peculiar cry may be heard from the deep sedgy ronds; and in the wilder portions of the Bure and the Ant, winding their sluggish course through the very heart of the Broad district, this bird abounds in the reedy borders, and is heard and seen at every bend of the stream. It is plentiful, also, in the Fen districts, both to the south and south-west of the county, and a few breed ammually in more central localities, such as Scoulton Mere, the haunt of the black-headed gulls; and on such of the meres about Wretham as afford sufficient harbour. Even Foulmere, though but a short distance from a farmhouse with all the busy sounds of human habitation, has attractions for this species, in a belt of rushes at one end of the water, but not so Ringmere or Langmere, though situated on a still wilder portion of Wretham heath. A few, I believe, are also to be met with in 3 I 
summer amongst the reeds on the saltmarshes about Salthouse and Cley, but fresh water localities are almost invariably preferred in the nesting season, when, in the same neighbourhood, they regularly frequent the ponds at Hempstead, near Holt; and in one part, in close vicinity to a water-mill, in spite of the constant noise of the flushes.*

Having observed these birds on "Bargate," the chief expanse of water on Surlingham Broad, still in flocks of from twenty to thirty as late as the second week in April, I imagine the nesting of the species does not usually commence before May; and from the first to the last week in that month I have found their eggs in various stages of incubation. The nests, which vary somewhat according to their situation, are all more or less compactly made, large in size, and composed of coarse materials so firmly interwoven that Mr. Hewitson states he has found them capable of supporting his weight. The outside of this ingeniously formed basket, usually consists of dried flags, reed, and other withered plants; but I have occasionally known the young reeds and rushes used in part, when the contrast of the fresh green has had a very pretty effect. The interior is lined with rather finer substances, chiefly with portions of the dead leaves of the reed. Though not unfrequently placed in dry situations-on the sedgy bank of an island, or the rushy margin of a pond or lake-I have more commonly found them, on the broads, built over the water amongst the reed-stems, in shallow spots, resting on the weeds at the bottom, in others well raised above the surface, but so fastened to the reeds themselves as to rise with the tide, though with

* Mr. J. H. Gurney has also observed this species on the river Mole, at Leatherhead, in Surrey, swimming about with joung ones at no great distance from the water-wheel of a mill. 
but little danger of their getting adrift.* When thus placed amongst the outlying reeds or rushes, growing half out of the water, the nest is rather conspicuous, and I have never found the eggs in any way covered; indeed, under these circumstances, there would not be sufficient materials at hand to do so effectively. The bird dives quietly from the nest, on the first alarm, and, like the water-hen, remains submerged till all danger is passed. When placed on the shore with plenty of dried litter around, probably the coot may, at times, take the precaution of covering its eggs before leaving them, but my own experience on this point differs entirely from that of Bishop Stanley, who describes the coot as commonly adopting this plan, whereas in no one instance have I seen it done. I have frequently found six and seven eggs in one nest, which I imagine to be the usual complement, but occasionally as many as ten are found by the marshmen. It is probable, also, that at times two birds may have laid in the same nest. When, as is some times the ease, not more than two or three are found, but those hard sat upon, the bird has most probably been robbed of her previous layings. The egrgs vary much in size in different nests, and the smaller ones are supposed by the marshmen to belong to the youngest birds; I have occasionally seen a waterhen's egg amongst them laid to the coots. William Hewitt, the keeper at Hoveton, many years back used to search the wet bottoms of the coots' nests for medicinal leeches, which at that time were worth one shilling a-piece, but none have been found in those waters for some years. As many as three and four

* Bewick gives an instance in which a coot's nest, built on Sir William Middlcton's lake at Belsay, Northumberland, was loosened from its moorings by the wind, and floated liere and there on the surface of the water. The hen bird, however, still continued to sit, and hatched off her young.

3 I 2 
might be taken from one nest, amongst the layers of coarse flag forming the foundation, and below the surface of the water.

The young coots in their nestling plumage are even more brightly-coloured than the young of the waterhens, as shown in Mr. Gould's plate in his "Birds of Great Britain;" yet, strange as those little creatures appear in their rich tints of orange, vermillion, and blue, from specimens I have seen at that particular stage, the artist's colouring can scarcely be termed exaggerated. This most interesting dress, according to $\mathrm{Mr}$. Gould, is retained only for three or at most four days, although the black down still marks their nestling state for some time longer, it is but rarely therefore that an opportunity offers for examining them so young, more particularly as even at that early period of their existence they quit the nest on the least alarm and seek shelter amongst the surrounding herbage, where, as is so accurately described by Bishop Stanley, they copy all the artifices of the parent birds, by diving and submersion, to conceal their tiny forms beneath the floating leaves. In their natural element, however, fresh dangers await them, and the pike, amongst their worst enemies, closes its hungry jaws upon many of these floating puffballs.

Under ordinary cireumstances the coot seems reluctant to take wing; and if disturbed on the water flies low over the surfice to the nearest shelter, dipping with its feet as it hurries along, but, like the water-hen, it makes more extended flights by night, and may be heard calling as it passes over head. Notwithstanding however, its nocturnal habits in this respect, the coot feeds by day, and is on that account supposed to attract wild-fowl to its haunts, which, relying on the wary nature of the coots to give the earliest intimation of danger, rest contentedly during the day-time when in 
such company. Their food consists in chief part of grasses and aquatic plants, with insects, worms, and slugs, when extending their researches to the land adjoining their watery home; they will also eat grain like the water-hen, though too shy to seek it in the same open and persistent manner.

"A broad without coots," writes Mrr. Lubbock, "would be London without sparrows or Newcastle withont coals," and the number reared ammually throughout that district ainidst a wilderness of reeds and rushes, must be something enormous, although, as compared with former days, their diminution might be estimated almost by the acreage of fen-land now under cultivation. At Horsey, years ago, as Mr. Rising informs me, a fair held every spring in that locality was known as "coot custard fair" from the fact of all the sweets being then made with the eggs of these birds and of black-headed gulls. At Surlingham, by no means a large piece of water compared with Hickling, Horsey, or Ranworth, five or six luundred eggs have been taken in a season according to $\mathrm{Mr}$. Lubbock, who, writing in 1845, speaks of their egrss being at that time much sought for, though "formerly the birds were unmolested till the young could fly." In autumn and winter they collect together on the open waters of the larger broads in immense flocks, their numbers greatly increased, at times, by migratory arrivals, and when thus collected together, large numbers have been killed at a shot, with big guns. A fen man at Hickling, on one occasion, in answer to Mr. Lubbock's question as to the number of coots visible, estimated them at "about an acre and a half,"* which, as that gentleman remarts, "is

*.The author of "British Field Sports" states that "he has actually beheld upon the Manningtree river, in Essex, a shoal of coots reaching two miles in length, as thick as they could well swim, and half a mile over." 
not so vague a mode of calculation as at first appears, for coots swim evenly at regular distances from each other without huddling together into dense masses like wild forvl." The same author speaks of the moorbuzzard or marsh-harrier being in former days useful to the fowler, "in driving the coots together so as to afford a better shot." He has known thirty-one killed at one discharge, when thus driven in by a pair of harriers. This habit of flocking together when attacked by the larger raptores is likewise referred to by Sir Thomas Browne, who, speaking of the great flocks of coots that in his time collected on the "Broad waters," remarks, "upon the appearance of a kite or buzzard, I have seen them unite from all parts of the shore, in strange numbers, when, if the kite stoops near them, they will fling up and spread such a flash of water with their wings, that they will endanger the kite, and so keep him off again and again in open opposition; and a handsome provision they make about their nest against the same bird of prey, by bending and twisting the rushes and reeds so about them, that they cannot stoop at the young ones or the dam while she sitteth." With regard to this latter statement, however, if such a device was ever practised by the coots in former days, for the protection of themselves and young, unquestionably their descendants, no longer in terror of moor-buzzards or kites, adopt no such precautions. According to Messrs. Sheppard and Whitear, also, the same tactics are displayed by the coots when attacked by the larger gulls, as they state that on one occasion they observed the former "on the approach of their enemy, rush together from all quarters, and form a close, round, compact body, appearing like bees in the act of swarming. The gull kept hovering over their heads, and frequently dashed within a yard or two of them. Whenever he 
fiew to a distance the coots dispersed, and again at his return flocked together." Mr. Rising, of Horsey, has a young glancous gull in his collection, which was killed in November, 184i, in the act of pouncing upon a dead coot. The coot was shot as it rose from a reed-bush, and the gull, which, with several more was flying over at the time, instantly pounced upon the coot, and was shot whilst standing on its intended prey.

The custom of attacking the coots with boats and guns, when collected in large bodies either in spring or autumn, is referred to by Messis. Sheppard and Whitear, ${ }^{*}$ in 1825, and is still adopted on some of our larger broads. At Hickling, where these birds collect together in immense numbers, a coot shooting party is an ammual institution. A day being fixed for the sport, boats, filled with gumners, assemble from the neighbouring villages to join the proprietor and his friends in a general fusillade, and outsiders, posted in every available spot upon the banks and marshes, are prepared to wait for a chance shot. The coots are then driven out of the reed-beds and bushes on to the open water, and the boats, advancing in line, work them gradually up towards one end of the broad. When thus closely pressed, they rise en masse, and sweeping back over the heads of the guniers, the battue opens on all sides, a dropping fire being kept up from the marshes as the birls scatter in their flight. The same method of collecting and driving is repeated, as soon as the coots have settled on the further extremity of the water, and this several times in succession, until the survivors are fairly driven from the broad, and

* The same authors also state that the fowlers on the Stour, were accustomed to approach the coots upon the ooze, "by concealing themselres behind a screen made of bushes, placed upon a sledge and driven before them." 
thus more than a hundred are generally obtained in one day. Considering, however, the reckless firing both on land and water, in the excitement of the sport, the miscellaneous character and questionable safety of many of the fire-arms, and the unskilful hands that use them, it seems an almost special act of providence that no serious accidents occur. It would be well also to confine this sport entirely to the winter months before the departure of the coots for the seacoast, as on their return in spring even the survivors are unsettled, and many driven from the locality; whilst I have known nine great crested grebes, just returned to their breeding haunts, indiscriminately slaughtered at the same time. On the 8th of December, 1868, I had the pleasure of joining a small party for coot and duck shooting, on Hoveton Broad. A very favourable breeding season, and the prolifie growth, even in the deeper waters, of that most troublesome weed, Anacharis alsinastmu were supposed jointly to account for the rnusual amount of coots, and the latter no doubt formed a special attraction for a consiclerable flock of tufted ducks. Our party being distributed about in favourable positions, some in boats and some on shore, the same means I have just described were adopted for collecting and flushing the birds, which were assisted in rising by a stiff breeze, and in the bright sunlight of a winter's morning, the appearance of that immense body of coots on the wing, when flushed on all sides at the first drive, was alone worth going to see; nor was the rushing sound of their wings less strange as they rose from the water. It was remarkable at what a distance the pure white forehead of this species could be distinguished, even in flight, and their pace when fairly mounted up, with the legs stretched out under the tail, fully justified Colonel Hawker's advice to shoot well forward, as a 
coot will carry off a considerable amount of shot if planted behind the wings.

Bishop Stinley thus alludes to the reluctance with which the coots quit the broads for the coast in severe weather:- "On a mere, where, from constant observation, we knew the precise number, they would remain as long as a few square yards of water were unfrozen, sitting on the ice, or swimming with a sort of despairing restlessness round their rapidly contracting space, as if unwilling, while hope of thaw was left, to seek shelter elsewhere." Mr. Lubbock also remarks-"when the water in general is frozen, they will crowd into the wake made by the swans, which always remains open long after the main pool is frozen. An opening of this kind is sometimes entirely filled with coots. They appear to dislike the migration to salt water, which is then their only resource, and to be willing to undergo any hardship rather than leave their beloved broad." I have found them in severe seasons, at Surlingham, when only a small channel remained open in the deepest parts of the broad still endeavouring to conceal themselves amongst the reeds and rushes. Even the noise made in cutting through the ice in order to bring the boat nearer to the edge of a reed-bed has failed to disturb them, but the dog finding a firm footing amongst the reeds, lias soon compelled them, one after another, to take wing, thus affording a succession of easy shots, and I have lnown six or seven started from an almost incredibly small space. Many, however, when shot in this manner are lost from their breaking through the ice in their fall and drifting under its surfice; and I once proved to demonstration, by this kind of shooting, the tendency of wire cartridges to carry like a ball, as a coot that fell to a very long shot upon the ice broke through, and in the same hole I picked up the bird and the empty cartridge case.

$3 \mathrm{~K}$ 
When compelled, howerer, from the necessities of hunger to quit the fresh waters for a time, the coots on any one broad migrate in a body, by night,* to the saltmarshes and flat oozy shores by the sea, and this so simultaneously that not a bird remains behind. There fresh persecution awaits them from the punt guns on Breydon and other parts of the coast; and in severe seasons their numbers are greatly thinned, some times twenty or more being lilled at one shot. The "cripples," as Mr. Frere tells me, that have escaped the gunners at the time are sure to be found secreted amongst the loose stones of the wall, which forms the boundary of those tidal waters, and a good retriever will thus pick up several in a morning, besides other fowl. He has also seen a coot, though quite dead, still clinging by its feet to the weeds under water, to which it had attached itself for the purpose of submersion and concealment. Many couples may be seen at such times for sale in our markets with other fowl, being offered at sixpence a piece, and when properly cleansed from the thick black down under the feathers, are said to be very fair eating, $\dagger$ but except amongst the marshmen and labouring population of our Broad district, they seem but little appreciated. Most of the fenmen, according to Mr. Lubbock, prefer them to a wild fowl. The pace at which a winged coot will run, when once landed on the ooze, is almost incredible,

* Captain Blakiston in a paper "on the Birds of the Interior of British North America" ("Ibis," 1863, p. 135), states that the American coot (Fulica americana) "has a habit of making a sharp rattling noise at night; and, moreover, is said to migrate during darkness only."

† Colonel Hawker, in his instructions for preparing coots for table, remarks particularly "that a coot shot in the morning, just after roosting, is worth three killed in the day when full of grass, because it will then be whiter and milder in flavour." 
and many thus escape by swiftness of foot; but whether thus endeavouring to save its life, or quietly picking its way over the "hoves" in summer, and feeding as it walks, all unconscious of danger, I could never perceive the awlwardness in its gait, remarked by some authors, although, like the water-hen, it has peculiar and distinctive actions.

I have no doubt that many of our home-bred birds, when frozen out on the broads and rivers, proceed southwards for a time, and swell the numbers that accumulate in hard winters about Poole harbour and other well-known resorts; there is no question, also, that our own flocks are largely increased at times by migratory arrivals. The so-called Salthouse "Broad," and marshes, were formerly a great resort of coots during the autumn and winter. In September, 1842, Mr. Dowell observed a flock there, numbering some five hundred birds, but which was not considered at all a large quantity, as hundreds would sometimes arrive in one night. Overton, the rell-known gunner on that part of the coast, always remarked that no matter what number of these birds might make the shore in the night, they would all arrive singly, dropped about, here one and there one, but in the morning they collected together into dense flocks. On their first arrival, also, they always swam close together, so that twenty or more might be killed at a shot, but after a day or two they separated when feeding, and still more so when alarmed according to their ordinary custom; in this respect differing much from the habits of most wildfowl. The spring migration commonly takes place in. March, when, preparatory to our residents pairing off for the season, the coots are again seen in large bodies upon our broad waters, and even then, as before stated, fresh attacks are not unfrequently made upon them. Varieties of this species are so rarely met with that I 3 K 2 
have never either seen or heard of one lilled in this county, but a curious eximple having the whole plumage white, except the head and tail, is stated by Messiss. Sheppard and Whitear to have been seen on the Stour, in 1825 .

\section{PHALAROPUS LOBATUS, (Linnæus).}

\section{GREY PHALAROPE.}

The Grey Phalarope, so termed from the prevailing tints of its winter plumage may, I have no doubt, be reckoned amongst our regular autumnal visitants, since scarcely a year passes but one or more specimens are recorded as either seen or procured; and although my notes from 1850 to the present time exhibit two or three exceptions to the general rule, these are owing, I believe, rather to a deficiency of information than the total absence of the species. By Messrs. Gurney and Fisher, in 1846, this bird was also described as visiting us "occasionally, but much less frequently," on its passage northward in spring, but though such may have been its former habit, I know of no single instance within the last thirty years of its appearing otherwise than at the close of the year. Of thixty specimens killed to my knowledge in various parts of Norfolk, during the last twenty years, two only have appeared as early as the month of September, fifteen in October, eight in November, four in December, and one in January, from which a pretty accurate idea may be formed of the ordinary date of their southward migration. Both the exceptional instances in the month of September, occurred in 1866, when an almost unprecedented number were killed in different parts of England, especially in the 
south-eastern and southern counties.* At that time, according to Mr. J. H. Gurney, jun., who publishedt a very interesting paper on this extraordinary immigration, the dites of their appearance ranged from the 20 th of August to the Sth of October, but the bulk of the specimens were procured between the $15 \mathrm{th}$ and 25 th of September, and the largest number, in one day, on the 18th of that month. From Mr. Gurney's painstaking researches it appear's that upwards of five hundred of these beautiful little creatures were sacrificed to the rage for collecting specimens, of which number two hundred and fifty were killed in Sussex alone, the habitual tameness of this species and its unsuspecting nature, everywhere exposing it to danger. It is difficult to account in any satisfactory manner for so remarkable an influx of a species, which, though a constant, has been rarely known as a numerous, visitant to our shores, but even if their abundance was in this instance the result of an unusually favourable breeding season, Mr. Gurney is probably right in presuming that their appearance on our eastern and southern coasts was owing to "the severe and premature gales" which prevailed in September of that year. As far as I could ascertain at that time, only four specimens were procured in Norfolk; the first on the 22nd of September, which was seen swimming in a small pond on Swardestone Common, and was killed by an old woman with

* Mr. Gould ("Birds of Great Britain,") speaks of a considerable flight which appeared some years since on the coasts of Deron and Cornwall when large numbers were killed during the month of October, and he further states that the first time this species was observed in abundance at Plymouth, was about five and thirty years ago.

$\uparrow$ "A Summary of the occurrences of the Grey Phalarope in Great Britain during the Autumn of 1866," by J. H. Gurney, juu. 
a stick; another shot on Breydon, in October, and two near Lym in December. Others, however, were said to have appeared on the coast in the neighbourhood of Hunstanton; and at Lakenheath, Suffolk, near the boundaries of the two counties, one was picked up dead, under the telegraph wires, on the 20 th of September.

In proof of my remark that, as a rule, this species is by no means a numerous visitant, I may state that, as shown by the entries in my note books of specimens procured, in no one year have they exceeded four or five, and that only in 1866 and in the autumn and winter of 1867. In all other cases their number has not exceeded two. It is stated, however, by Messrs. Paget that in 1828 eight or nine specimens were killed near Yarmouth. By far the larger proportion of those of which I have any record have been killed in close vicinity to the coast, though commonly on some pond or stream of fresh water; and the brackish waters at the back of Salthouse beach are a favourite resort, from whence I have had two or three examples. Occasionally, they have been found far inland, as in 1854, when a pair were shot at Hellesdon Mills, near Norwich; and the one killed at Swardestone in 1866, is another instance. In the "Zoologist" for 1847 (p. 1640), Mr. C. B. Hunter records the appearance of four grey phalaropes, in the winter of 1846, " on the pond belonging to the farm at Foulmere on the Wretham estate. They were swimming about, quite tame, with the ducks belonging to the farm," and had frequented that spot for about three weeks. Soon afterwards one was shot out of four on a Mere close to Wretham Hall, which were no doubt the same as had been previously observed. This bird is also recorded by $\mathrm{Mr}$. A. Newton in the "Zoologist" (p. 1693.)

Most of the specimens I have examined, killed in this county, have been young birds of the year, but some of the 
older ones have still shown traces* of the rich bay tints of their summer plumage, which contrast so strangely with the delieate grey and white of their winter dress. In this species, as with the dotterel (Chamentius murinellus), the female is both larger in size and brighter in the colours of its nuptial dress than the male; and a still greater anomaly is pointed out in the following passage from Gould's "Birds of Great Britain," "I am informed by Professor Steenstrup, of Copenhagen, that the duty of incubation appears to be performed by the male only-a circumstance which appears to be confirmed by the bare state in which the breasts of specimens of that sex are often found." Mr. Harting, who has recently had an opportunity of observing the habits of this graceful little bird, remarks ("Zoologist," 1870, p. 1973) that a specimen which he afterwards secured for his collection, when "swimming round and about, now and then pecking at some water-weed, seemed to resemble the gallinules; like them nodding the head at erery stroke of the foot. When standing on the ground at a little distance, it looked not unlike a ringed-plover, but at this season of the year it was much whiter." Its foor consisted of small flies and beetles, with a slight admixture of vegetable matter.

\section{PHALAROPUS HYPERBOREUS (Limnus).}

\section{RED-NECKRD PHALAROPE.}

This species, which is readily distinguished from that last described by its smaller size, and longer and more

* See some remarks on the autumnal change of plumage in the grey phalarope, by Mr. M. A. Matthew, in the "Zoologist" for $186 j$ (p. 500). Mr. Blake Knox, also ("Zoologist," 1867, 1. 68:") 
slenderly-formed bill, has become exceedingly rare on our coast of late years, and even in former times appears to have been a far more irregular visitant than the grey phalarope, although occasionally met with both on its autummal and vernal migrations.* Since the year 1850, a period of just twenty years, the following are the only instances of its occurrence that have come to my notice :-

1850. October 20th. One killed near Yarmouth.1851, October 24th. One in Mr. Dowell's collection, shot at Blakeney; several more "little swimming birds" were said to have been seen at the same time, but whether of this or the grey species is not known.-1853, November: 9th. A solitary female was shot by Mr. J. Brownfield, of this city, in the act of skimming over the river at Trowse Eye, near Norwich, as recorded in the "Naturalist" for 1854 (1. 161).-185\%, November 4th. Morris, on the authority of $\mathrm{Mr}$. James Hunt, records a specimen as lilled at this date at Yarmouth, near the mouth of the river.-1859, September 23rd. One at Hickling.-1867, May 24th. A male in the collection of $\mathrm{Mr}$. Overend, of Yarmouth, was killed near Horsey Mere, as recorded in the "Field" on the 1st of June (vol. xxix).-1868, October 31st. A bird of the year, in winter plumage was shot at Stalham, and preserved for Mr. Silcock, of that place. An immature specimen was also shot at Lakenheath Fen, Suffolk,

remarks upon the lightness and transparency in the texture of the feathers of this species, most apparent in the winter grey feathers which, "when orcrlapping a summer feather, the summer feather can be seen through it as through a mist."

* It is somewhat singular that according to M. Van Wickevoort-Crommelin, who has published an excellent paper upon it ("Archires Nécrlandaises," 1867 (pp. 76-83), this species has only lately occurred in Holland (20th of September, 1860), though the grey phalarope has been often obtained there. 
on the 28th of Norember, 1860 , as recorded in the "Zoologist" for 1861 (p. 7316).

It is remarkable, however, that a species so uncertain in its movements, even when more plentiful than it is now, should have appeared in unusual numbers, on the same part of our coast, and in three successive seasons, as shown by the various records in the "Zoologist" from 1846 to 1849 . In that jommal for 1846 (p. 1552), Mr. J. H. Gurney states that he received during the 1st week of November a specimen of this phalarope from Salthouse, which he believed to be the fourth procured in that neighbourhood during that autumm; arding that the last Norfolk specimen he had seen was killed several years before at the adjoining parish of Weyborne, by the late Sir T. F. Buxton, who described it as "swimming like a duck" when first noticed. Probably one in Mr. Dowell's collection, shot at Salthouse, as early as the 21st of July in that year, is one of the four thus mentioned. In the "Zoologist" for 1847 (p. 1955), Messrs. Gurney and Fisher remark, "we have seen four specimens of the red-necked phalarope, which were killed at or near Salthouse during the month of September. Two of these, which were killed in the beginning of the month, retained much of the summer plumage; in the other two, which occurred about the end of the month, it had almost entirely disappeared." Of these $\mathrm{Mi}$. Dowell has one in winter plumage. According to the same authors, also, a single bird of this species was killed at Weyborne on the 3rd of October, 1847 ("Zoologist," 1843, p. 1965); and on the 26th and 30 th of September, 1818, two specimens were procured at Waxham, near Yarmouth, as recorded in the "Zoologist" for 1849 (p. 2353). Of those above enumerated, three specimens are in Mr. Gurney's collection, and a pair, I believe, in Mr. Upcher's possession at Sheringham Hall. The partiality of this $3 \mathrm{~L}$ 
species, as well as the grey phalarope, for the brackish waters on Salthouse beach and the adjacent marshes, is singularly marked in the abore instances, all but one having been obtained on that particular point of the coast. About Yarmouth, even as far back as 1834, they were described by Messrs. Paget as "very rare," although Mr. Miller possessed a pair-one in winter and one in summer plumage-the former possibly the same mentioned in Sir William Hooker's MS. notes as killed on Breydon in the winter of 1824, but this species is not mentioned by Messi's. Sheppard and Whitear. I have never been able to secure a recent example of this phalarope for my own collection, but I lately purchased a stuffed specimen which was shot at Scoulton Mere, in August 1829, the only occurrence in that montl with which $I$ am acquainted.

From the above dates, then, both of the earlier and more recent examples, it appears that the autumnal migration of this phalarope, like that of the more numerous species, occurs most commonly in the months of September, October, and November; there is no record of its appearance either in December or January. It would seem, however, from the bird killed at Yarmonth, in May, 1867, that this species, occasionally at least, adopts the same route in spring, on its passage northward, as on its southward migration; yet in the case of Mr. Dowell's bird, killed on the 21st of July, it is difficult to say what direction it was pursuing at the time, as in Dumn's "Ornithologist's Guide to Orkney and Shetland," the rerl-necked phalarope is said to arrive in the Orkneys in July and to breed there in August. At least such was the case in 1837; but, according to the same authority, as quoted by $\mathrm{Mr}$. More in his "Distribution of Birds in Great Britain during the nesting season" ("Ibis," 1865, p. 439), it is no longer found in the Orkneys, a fact which may in 
some degree account for its extreme scarcity during the last ten years, on the Norfolk coast, as compared with former days. It still breeds, however, according to Mr. More, in a few scattered localities in the counties of Perth, Inverness, Sutherland, and in the Outer Hebrides; and Mr. H. J. Elwes, I am told, found it breeding in Benbecula, one of the Western Isles, and took nests of four eggrs each in the first week of June, 1868.

With reference to the note at p. 440, on the recent occurrence only, according to M. Crommelin, of this species in Holland, I may add that Mr. Keulemans, as I am informed by Mr. J. E. Harting, once shot a rednecked phalarope, on the coast of Holland, in winter. Temminck ("Man. d'Orn.," 1st ed., p. 458), undoubtedly claimed it as an accidental straggler to Holland, but if such had been the case, it is, at least, a singular fact, as stated by M. Crommelin, that not a single example should be found in any collection in that country.

This species is subject to a considerable seasonal change of plumage, though scarcely to the same extent as the grey phalarope, and the female is larger in size, and in summer brighter in colour, than the male. 
END OF VOL II. 


\section{INDEX.}

A

American Bittern, 174.

Ardea alba, 149

$$
\begin{aligned}
& \text {, cinerea, } 130 \\
& \Rightarrow \quad \text { comata, } 151 \\
& \text { gar } \approx \text { etta, } 150 \\
& \text { purpurea, } 145 \\
& \text { missata, } 151
\end{aligned}
$$

Avocet, 237

\section{B}

Baillon's Crake, 4.01

Bar-tailed Godwit, 253

Battue Coot shooting, 431

Bidcock-Water Rail, 404

Birds-abundance of some species in hard weather, $69,171,285$, $356,372,435$

" attracted by gas lamps when migrating by night, 70,195 , 277,409

" deformed beaks or feet in, 424

" killed against lighthouses, 195, $276,377,409$

" killed against telegraph wires, $68,277,334,377,392,395$, 438

" migratory, returning to same spot, 283, 291

" netting of in the fens and on the coast, 111, 124, 376

parasites of, 348

" trustworthy as weather guides, 66

" varieties of-see VARieties

" various notes of in each species, $93,197,341$

" various species migrating in company, 71, 73, 74, 75, 90, 195
Birds-wholesale destruction of, and their egge, deprecated, 79, 89, $104,106,170,207,203$, $281,308,312$

Bittern American, 174

" common, 159

$"$ " hawking of, 173

," little, 154

Bittour or Bittern, 173

Blackbirds migrating with roodcocks, 275

Black Curlew or Ibis, 191

Black-tailed Godwit, 248

Black-winged Stilt, 244

Black Stork, 182

Botaurus lentiginosus, 174

" minutus, 154

, stellaris, 159

Bottleybump or Bittern, 166

Broads, sunset ou the, 163

Broad-billed Sandpiper, 359

Brown Snipe, 3.8

Browne Sir Thomas, collection of eggs, \&c., 128

Buff-backed Heron, 151

Buff-breasted Sandpiper, 358

Bustard great, 1

"gular, pouch of, 3

" coursing of with greyhounds, 22

" list of local specimens and eggs in collections, 32

migratory habits of, 29

Bustard little, 42

\section{C}

Calidris arenaria, 116

Cambridge Godwit, 204.

Carolina Crake in England, 392

Cayenne Night Heron, supposed specimen of, 175 
Charadrius cantianus, 97

hiaticula, 84

intermedins, 95

minor, 96

" morinellus, 76

, pluvialis, 66

Ciconia alba, 177

,1 nigra, 182

"Clinkers or Avocets, 240

Collared Pratincole, 64

Common Bittern, 159

" Curlew, 194

" Heron, 130

, Redshank, 207

" Sandpiper, 230

" Snipe, 305

Commons, inclosure of, 104

Coot, 425

" battue shooting of, $43 \mathrm{l}$

" leeches in nests of, 427

" custard fair, 429

Corn Crake, 387

Courser cream-coloured, 48

Crake Baillon's, 401

" Carolina, 392

" corn, 387

"little, 396

" spotted, 393

Crane, 125

Crex bailloni, 401

"porzana, 393

, pratensis, 387

"pusilla, 396

Crus cinerea, 125

Curlew black, 191

" common, 194

" great harvest, 198

" pigmy, 350

, stone, 51

Curlew Sandpiper, 350

Cursorizs europous, 48

\section{D}

\section{Dotterel, 76}

" havking of, at Thetford, by

King James I., 82

origin of the word, 84

Double Snipe, 299

Drainage, effects of on wild species, 306

"Drain" Dunlins, 382

Dunlin, 371

" enormous flocks of, 374

" large and small races of, 380

, migrating by night, 378

netting of, 376
E

Eggs, collection of Sir Thos. Browne, 128

„false statements of dealers in, 154

, numbers of taken, and various methods employed, 93, 105, 429

Egret little, 150

Egrittes, Lapwings, 151

\section{F}

Flood the great in the fens, 116, 207, 250,283

Fulica atra, 425

\section{G}

Gallinula chloropus, 411

Glareola torquata, 64

Glossy Ibis, 191

Godwit bar-tailed, 253

" black-tailed, 248

" Cambridge, 204

, day on Breydon, 253

Golden Plover, 66

Great Bustard, 1 whistling over the city by night, 70

"Plover, 51

"Snipe, 299

,White Heron, 149

Green-legged Shank or Knot, 357

Green Plover or Lapwing, 103

, Sandpiper, 215

Greenshank, 234

Grey Phalarope, 436

„Plover, 101

"Snipe, 348

H

Homatopus ostralegus, 122

Half Snipe, 334

Harnser or Heron, 130

Hawking bitterns, 173

" curlew, 64

" dotterel, 82

" herons, 132, 136

", stone curlew, 64

Heron common, 130

" hawking of, 132, 136

" attacking water-hens, 418

" great age of, 139

" passage of, 138 
Heron buff-backed, 151

" great white, 149

" night, 174

" purple, 145

" squacco, $] 51$

"Hill" of ruffs, 268

Himantopus melanopterus, 244

Household Book of the L'Estranges, extracts from the, 2, 76, 87, 103, $125,126,136,142,173,198,202$, $215,271,275,280,324,357,373$, 424

Ditto the Northumberland, 78, 112, $125,127,141,173,184,215,324$, 357,374

Ditto the Lord North, 76, 78, 112, $127,141,173,199,253$

\section{I}

Ibis falcinellus, 191

Ibis glossy, 191

$$
\text { J }
$$

Jack Suipe, 334

\section{K}

Kentish Plover, 97

Knot, 354

\section{L}

Landrail, 387

Lapwing, 103

Leeches in bitterns' nests, 168

," in coots' nests, 427

L'Estranges of Hunstanton, extracts from Household Book of the, 2, 76, $87,103,125,126,136,142,173$, $198,202,215,271,275,280,324$, $357,373,424$

Limosa melanura, 248

rufa, 253

Little Bittern, 154

"Bustard, 42

" Crake, 396

" Egret, 150

, Gallinule, 396

" Ringed Plover, 96

, Stint, 361

\section{MI}

Machetes pugnax, 261

Macrorhamphus griseus, 348
Martin Snipe, 224

Maybird or Whimbrel, 199

Maychit, 233

"Meals," plants found on the, 275

"News," derivation of the term, 357

Migration evidences of, by night, 67, $70,90,378$

" with or against the wind, 273

Moorhen, 411

" extraordinary instinct of a, 413

\section{N}

Nests singularly constructed or in strange localities, $131,216,415$, 416

Netting of plover, \&c., in the fens, 111 " of various species on the coast, 124,376

Night Heron, 174

Norfolk Plover, 51

$$
\text { " hawking of, } 64
$$

North the Lord, extracts from Household Accounts of, 76, 78, 112, 127, $141,173,199,253$

Northumberland Household Book, extracts from, $78,112,125,127,141$, $173,184,215,324,357,374$

Numenius arquata, 194

" phocopus, 199

Nycticorax gardeni, 174

\section{O}

Edicnemus crepitans, 51

Olivaceous Crake, 396

Otis tarda, 1

"tetrax, 42

Oxbird or Dunlin, 379

Oyster catcher, 122

$\mathrm{P}$

"Passage" Herons, 138

Pectoral Sandpiper, 367

Peewit or Lapwing, 103

"Picks" and "Scamells," Godwits, 260

Pigmy Curlew, 350

Phalarope grey, 436

, red-necked, 439

Phalaropus hyperboreus, 439

$$
\text { "lobatus, } 436
$$

Platalea leucorodia, 184 


\section{Plover great, 51}

" green or Lapwing, 103

, golden, 66

" grey, 101

„ Kentish, 97

„ little-ringed, 96

" netting of in the fens, 111

, Norfolk, 51

, ringed, 84

" small race of, 95

Pratincole collared, 64

Purple Heron, 145

„Sandpiper, 384

\section{R}

Rail land, 387

, water, 404

Rallus aquaticus, 404

Recurvirostra avocetta, 237

Red-breasted Snipe, 348

Redleg or Redshank, 213

Redshank common, 207 spotted, 203

Red-necked Phalarope, 439

Reeve, 261

Ringed Plover, 84

Ringlestones, 86

small race of, 95

Ruff, 261

\section{S}

Sabine's Snipe, 343

"Sand-flood," strange record of at Santon Downham, 17

Sanderling, 116

Sandpiper broad-billed, 359

") buff-breasted, 358

„ common, 230

" curlew, 350

green, 215

, pectoral, 367

, purple, 384

" spotted, 233

" wood, 226

" yellow-shanked, 215

Scolopax brehmi, 333

, gallinago, 305

". gallinula, 334

" major, 299

", russata, 332

" rusticola, 272

"Sabinii, 343

Sea Woodcock, 260

Sea Dotterel, 86
Sea-pie, 122

"Shoeinghorn," or Arocet, 237

Shovelard or Spoonbill, 184

Snipe common, 305

$$
\begin{aligned}
& \text { " " abundance of at times, } \\
& 326
\end{aligned}
$$

Snipe brown, 348

13 great, 299

" grey, 348

" jack, 334

" " abundance of at times, 338

" martin, 224

"red-breasted, 348

"Sabine's, 343

"summer, 224, 230

"Solitary" Snipe, 299

Spoonbill, 184

Spotted Crake, 393

" Redshank, 293

" Sandpiper, 233

Spowes or Whimbrel, 201

Squatarola cinerea, 101

Squacco Heron, 151

"Stale," origin of the term, 267

Stilt blackwinged, 244

Stints or Dunlins, 373

Stint American little, 366

" little, 361

, Temminck's, 363

Stone Curlew, 51

Stonehatch, 85

Stork black, 182

", white, 177

Strepsilas interpres, 113

Summer Snipe, 224, 230

Sunset on the broads, 163

\section{$\mathrm{T}$}

Tangle-picker, 1$] 4$

Telegraph-wires destructive to birds, $68,277,334,377,392,395,438$

Temminck's Stint, 363

Totanus calidris, 207

, flavipes, 215

"fuscus, 203

" glariola, 226

"glottis, 234

" hypoleucus, 230

" macularius, 233

, ochropus, 215 
Tringa, canutus, 354

i) maritima, 381

,, minuta, 361

", pectoralis, 367

" platyrhyncha, 359

,p pusilla, 366

" rufescens, 358

", subarquata, 350

, temmincki, 363

" torquata, 381

, variabilis, 371

Turnstone, 113

\section{V}

Varieties, 110, 199, 201, 215, 295, $333,384,421,436$

\section{W}

Waders, power of diving and swimming in, $122,233,357$

Water-hen, 411

" abnormal plumage in, 421

Water-rail, 404
Whimbrel, 199

Whistling Plover, 66

White Spoonbill, 184

,, Stork, 177

"Whole" Snipe, 334

Wolley's the late MIr. John, donation to the Norwich Museum, 361, 365

Woodcock, 272

" abundance of in some seasons, 280,284

, large and small race of, 293

" mode of carrying their young, 292

" probable cause of diminution, 280 remaining to breed, 287

" weight of, 294

, sea, 260

"Woodcock" snipe, 304

Wood Sandpiper, 226

"Wypes" or Lapwings, 109

\section{$\mathrm{Y}$}

"Yarwhelp" or Godwit, 252

Yellow-shanked Sandpiper, 215 
NORIVICH :

GTEVINSON AND CO., PRINTERS, MARKET PI.ACE. 
THE BIRDS OF NORFOLK. By HENRY STEVENSON, F.L.S., INember of the British Ornithologists' Union. Vol. II. just published (to be completed in 3 vols.), demy 8 ro, $419 \mathrm{pp} .$, prico 10s. 6d., with Colonred Frontispiece by Wolf of the Great Bustard, and Lithographic Views of Breydon "MLuds" and Thetford Warren.

Owing to the greatly increased amount of information receired since the plan of this work has been more generally known, the author has been obliged to adopt one of two alternatives, either to publish a third rolume or to curtail so considerably the remaining portion of the work as entirely to destroy its uniformity. Adopting the former course, with the adrice of many fricnds and subscribers, he has here completed the large and important group of Grallatorial Birds, reserring the Anatidw aud a general appendix for the concluding Folume.

\section{OPINIOIVS OF IIEA PRESS.}

"On the whole, this is a delightful book for the naturalist conscientiously and lovingly done, and imbued with that genuine love of nature in her most charming creation which, in Gilbert White and many another compeer, has en. riched our literature with books full of infinite resource and tranquil pleasure. TVe have given copious extracts, in order that our readers may judgo for them. selves if our praises be deserved, in the full confidence that those who may take our recommendation on trust will be fully content with the result. - Times.

"The first volume of the "Birds of Norfolk" will, we are sure, bo welcomed by all our readers in this country with great delight; for we have no hesitation in saying that it is the most meritorious book of its kind that has appeared for many years." - Ibis.

$\therefore$ A book which seems to be of such special merit as to deserve a much more extended circulation than is generally accorded to works on rarious limited branches of natural history. *** Here we have the feelings of the genuine lover of nature, expressed in language which is like TVordsworth done into prose." -Frazer's Magazine.

"The comfort of a cut book may have something to do with it, but certainly we have seldom read a new volume with more pleasure than this one, on the Birds of Norfolk. * * * Mr. Stevenson not merely gives his readers trustworthy information; he makes them feel his enthusiasm; and he fills their imagination 3 with pictures of what he has seen."-Athenoum.

"All will read it (or should do so) who are interested in the natural history of the Eastern Counties. To ornithologists it will be welcome, as the production of a field naturalist and a practical observer. And to the general reader it will commend itself by its popular style, the absence of pedantry, and the presence of an earnest purpose and an ardent love for the feathered ormaments of God's creation.-Science Gossip.

"A very undue estimate of its merits would be formed if it were supposed to possess claims to arwaken a local interest alone, for though professedly treating of the Birds of Norfolk, it contains many ornithological facts of general impurt." - Morning Post.

"So many works have appeared on the general subject of British Birds, that it may be thought tolerably exhausted; but wo have here a production of unusual merit, which we shall review in some detail."-Land and Water".

"This work is one of those masterly contributions to British Ornithology which it is the peculiar province of the 'Zoologist' to introduce to every one of its readers as an essential addition to his library."-Zoologist.

"Here is a book which may safely be recommended as a model of what a local fauna should be. * * * The ornithologist and man of science generally will find the book a well-arranged storehouse of facts." - The Gardener's Chronicle and Agricultural Gazette.

"For the last twenty years MIr. Stevenson has been most industriously at work, and has not only gleaned ornithological facts from every arailable source, but has been in his own person a constant and most unwearying observer." Field.

Loxdox: J. FAN TOORST. FoRWICH: STEVEXSON AYD CO. 

YARRELL'S BRITISH BIRDS. To be Edited by AqrReD Newrox, M.A., Professor of Zoology and Comparative Anatomy in the University of Cambridge, \&c., \&c.

THE BIRDS OF NORFOLK. By Henry Stevenson, F.L.S. Vols. 1 and 2, 8ro., each 10s. 6d.; Vol. 3 will complete the work.

Post 8vo., cloth, $665 \mathrm{pp} ., 7 \mathrm{~s} .6 d_{\text {. }}$

THE BIRDS OF SOMERSETSHIRE. By Cecil Smite, of Lydeard House, near Taunton.

$$
\text { Post 8vo., cloth, 7s. } 6 \text { d. }
$$

THE BIRDS OF MIDDLESEX. A contribution to the Natural History of the County. By James Edmund Harting, F.Z.S.

$$
\text { Price 7s, 6d., a Third Edition of }
$$

ORNITHOLOGICAL RAMBLES IN SUSSEX, with a Catalogue of the Birds of that County, and Remarks on their Local Distribution. By A. E. Kvox, M.A., F.L.S., F.Z.S.

Part 1., Royal 8vo., cloth, 7 s. $6 d$.

A DESCRIPTIVE CATALOGUE of the Raptorial Birds in the Norfolk and Norwich Museum. By John Henry Gurney.

Large Folio, cloth, £2 $2 s$.

FALCONER'S FAVOURITES. By W. BRoDrick, one of the Authors of "Falconry in the British Islands." A series of Lifesized Coloured Portraits of all the British species of Falcons at present used in Falconry.

Post 8vo., with Four Tlustrations, 6s.

FALCONRY IN THE VALLEY OF THE INDUS. By R. F. BURTON.

8vo., price 12s.

A DICTIONARY OF BRITISH BIRDS, containing a full account of the Plumage, Weight, Habits, Food, Migrations, Nest and Eggs of every Bird found in Great Britain and Ireland. Edited by Edward NewaAn, F.L.S. F.Z.S., \&c.

Third Edition, 2 vols., 8vo., \&4 14s. 6d.

COLOURED ILLUSTRATIONS OF THE EGGS OF BRITISH BIRDS, with Descriptions of their Nests and Nidification. By Willias C. Hewitson.

On Writing-paper, 8vo., 8s. $6 d$.

SYSTEMATIC CATALOGUE OF THE EGGS OF BRITISH BIRDS, arranged with a view to supersede the use of Labels for Eggs. By the Rev. S. C. Maran, M.A., M.A.S.

BIRDS OF JAMAICA. By P. H. Gosse, F.R.S. Post $8 v o .10 s$.

THE IBIS: A Quarterly Journal of Ornithology. Edited by Alfred Newton, M.A., F.L.S., \&c. 


